\title{
Tanatoturystyka
}


$\frac{3}{40}$ 


\section{Stawoj Tanaś}

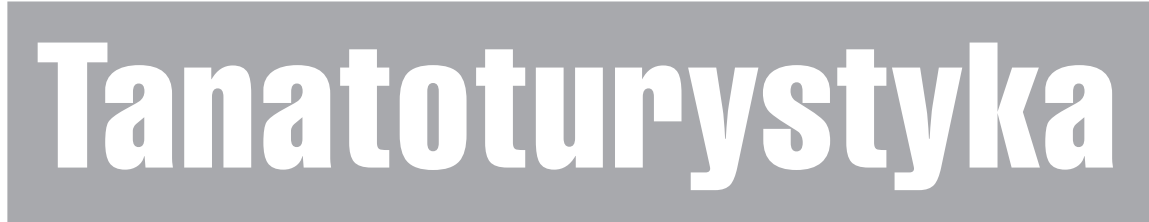

\section{Od przestrzeni śmierci do przestrzeni turystycznej}


Sławoj Tanaś - Pracownia Rekreacji i Turystyki Kwalifikowanej Instytut Geografii Miast i Turyzmu, Wydział Nauk Geograficznych

Uniwersytet Łódzki, 90-323 Łódź, ul. Kopcińskiego 31

RECENZENT

Antoni Jackowski

PROJEKT OKŁADKI

Marek Mazurek

FOTOGRAFIA NA OKŁADCE

Kościół cmentarny pw. Wszystkich Świętych w Kutnej Horze w Czechach Stawoj Tanaś

ADIUSTACJA, REDAKCJA TECHNICZNA

SKŁAD I ŁAMANIE

Elżbieta Paradowska

RYSUNKI

Anna Wosiak

Wydrukowano z gotowych materiałów dostarczonych do Wydawnictwa UŁ

(C) Copyright by Uniwersytet Łódzki, Łódź 2013

Wydane przez Wydawnictwo Uniwersytetu Łódzkiego

Wydanie I. W.06271.13.0.H

ISBN (wersja drukowana) 978-83-7525-924-7

ISBN (ebook) 978-83-7969-218-7

Wydawnictwo Uniwersytetu Łódzkiego

90-131 Łódź, ul. Lindleya 8

www.wydawnictwo.uni.lodz.pl

e-mail: ksiegarnia@uni.lodz.pl

tel. 426655863 , faks 426655862 


\section{SPIS TREŚCI}

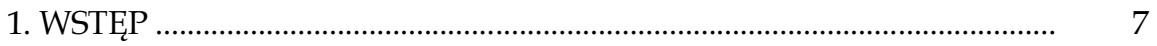

2. ŚMIERĆ I KULTURA …................................................................................ 17

2.1. Zmienność interpretacji śmierci a tanatoturystyka ............................... 17

2.1.1. Krótka historia śmierci ................................................................. 18

2.1.2. Tabu śmierci ............................................................................... 23

2.2. Dziedzictwo kulturowe śmierci ............................................................. 28

2.2.1. Kultura śmierci ........................................................................... $\quad 30$

2.2.2. Śmierć a tożsamość kulturowa .................................................... 38

2.2.3. Popkulturowy wymiar śmierci ....................................................... 43

2.2.4. Okrucieństwo i transparencja śmierci ........................................ 48

3. GEOGRAFIA KULTURY ŚMIERCI .......................................................... 53

3.1. Geografia kultury a przestrzeń śmierci .............................................. 54

3.2. Śmierć w geografii podróży kulturowych ............................................ 56

3.2.1. Podróże pielgrzymkowe .............................................................. 58

3.2.2. Podróże kulturowe ........................................................................ 68

3.3. Geografia śmierci .............................................................................. 79

3.3.1. Przestrzeń śmierci ..................................................................... 79

3.3.2. Nekrogeografia - idea geograficznych badań nekropolii .......... 85

3.3.3. Koncepcja geografii śmierci ..................................................... 92

4. CZŁOWIEK W PRZESTRZENI TANATOTURYSTYKI .............................. 99

4.1. Turystyka kulturowa ............................................................................ 100

4.1.1. Turystyczna percepcja kultury....................................................... 103

4.1.2. Turystyczny dystans międzypokoleniowy ................................. 105

4.2. Związki przestrzeni śmierci z przestrzenią turystyczną ...................... 109

4.2.1. Kulturowa przestrzeń turystyczna .............................................. 116

4.2.2. Przestrzeń tanatoturystyki ........................................................ 119

4.2.3. Determinanty rozwoju przestrzeni tanatoturystyki ................... 122 
4.3. Edukacja w przestrzeni tanatoturystyki .................................................. 126

4.3.1. Przestrzeń pamięci ......................................................................... 126

4.3.2. Edukacja i wychowanie ................................................................. 133

4.3.3. Krajoznawstwo w przestrzeni tanatoturystyki ............................ 135

4.4. Rozwój przestrzeni tanatoturystyki na przykładzie pamięci o aktach terrorystycznych i ludobójstwie ................................................................ 138

4.4.1. Terror i ludobójstwo jako bariera ruchu turystycznego ............. 141

4.4.2. Pamięć o terrorze i ludobójstwie jako stymulator ruchu turystycznego ..................................................................................... 148

5. ISTOTA TANATOTURYSTYKI ................................................................... 153

5.1. Atrakcyjność turystyczna kultury śmierci ........................................... 157

5.2. Motywy podróży tanatoturystycznych ................................................ 165

5.3. Moralne dylematy tanatoturystyki ................................................... 170

5.3.1. Turystyczna postawa wobec śmierci ........................................ 171

5.3.2. Moralny aspekt tanatoturystyki ................................................ 173

5.3.3. Znaczenie traumy $\mathrm{w}$ tanatoturystyce .......................................... 181

5.4. Typologia tanatoturystyki ................................................................. 185

5.5. Geografia tanatoturystyki .................................................................. 194

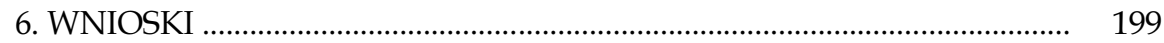

Literatura _................................................................................. 203

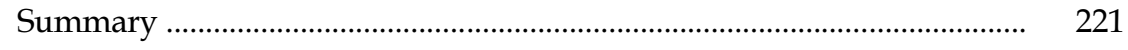




\section{WSTĘP}

Intensywny rozwój światowej turystyki determinuje organizację przestrzeni turystycznych będących rezultatem zmieniających się w czasie potrzeb konsumpcyjnych turysty, które decydują o odkrywaniu nowych obszarów dla turystyki, choć znanych wcześniej, to nie zawsze z nią identyfikowanych. We współczesnej turystyce kulturowej, w ramach której turysta odwiedza miejsca stanowiące lub prezentujące materialne i niematerialne dziedzictwo historyczne $\mathrm{i}$ artystyczne, powszechna jest m.in. śmierć.

W czasie, kiedy podróże nabrały cech dobrowolności rozpoczęła się era turystyki, rozumianej jako czasowe przemieszczanie się dla przyjemności i osobistego kontaktu ze środowiskiem odwiedzanym (przyrodą, kulturą i społeczeństwem) (PRZECŁAWSKI 1979). Choć początki turystyki upatrywane są $\mathrm{w}$ podróżach o charakterze religijnym, edukacyjnym i handlowym, to współcześnie turystyka kojarzy się najczęściej z poznaniem, wypoczynkiem, rozrywką i realizacją własnych zainteresowań.

Średniowieczna Europa była przestrzenią pielgrzymowania przede wszystkim do grobów ludzi, którzy odegrali znaczącą rolę w historii chrześcijaństwa (JACKOWSKI 2003). Były to m.in. Jerozolima z grobem Jezusa, Rzym z grobem św. Piotra czy Santiago de Compostela z grobem św. Jakuba. Rozwój uniwersytetów sprzyjał wędrówkom żaków, a rosnące potrzeby konsumpcyjne wiązały się z podróżami kupców, dzielących się swoją wiedzą o świecie z mieszkańcami odwiedzanych obszarów. Rozwój środków komunikacji i otwartość na świat sprzyjała coraz dalszym i dłuższym podróżom, $\mathrm{w}$ trakcie których wędrowcy poznawali inne kultury, a społeczności przez nich odkrywane dowiadywały się o istnieniu nieznanych im cywilizacji.

Podane powody pierwszych podróży, spełniających współczesne kryteria wędrówek turystycznych, można odnieść nie tylko do średniowiecznej Europy, ale również do historii turystyki na całym świecie. Dzięki podróżom sukcesywnie dochodziło do wzajemnego poznawania kultur i przekazywania wiedzy o społecznościach lokalnych, ich tradycjach, obrzędach, wierzeniach i prawach. Nieznany świat kreował potrzebę poznania, w tym poznania zarówno geograficznego, jak i kulturowego. Różnorodność kulturowa napędzała rozwój ekonomiczny świata, a ten z kolei postęp cywilizacyjny 
prowadzący wielokrotnie do konfliktów i wojen. W ten sposób zainteresowanie otaczającym człowieka światem rozwijało jego potrzeby poznawcze.

Wraz z upływającym czasem celem podróży turystycznych stała się również chęć poznania wytworów kultury. Podróże odbywały się i nadal często pozostają w związku ze „śmiercią drugiego" (ARIÈs 1979). Postawy wobec śmierci i zmarłego kształtowane były przez całą historię ludzkości, czego wyrazem jest dziedzictwo kulturowe, przejawiające się obyczajowością, normami postępowania, symboliką oraz twórczością artystyczną, które od zarania były przedmiotem zainteresowania człowieka. Przestrzenie śmierci były od wieków odwiedzane w ramach podróży pielgrzymkowych zarówno $\mathrm{w}$ charakterze religijnym, jak i historycznym mających na celu upamiętnienie i kult zmarlych. Przestrzenie śmierci wykorzystywane w procesie edukacji i wychowania współcześnie stanowią walor, który jest podstawą organizacji atrakcji i produktów turystycznych kreowanych pod wpływem popytu rynkowego.

Turystyka kulturowa w świecie zachodnim rozwija się intensywnie od XIX wieku. Od tego czasu jej początkowo elitarny charakter stopniowo nabrał cech masowości, by $\mathrm{w}$ drugiej połowie $\mathrm{XX}$ i na początku XXI stulecia wytwory kultur uległy popularyzacji, stając się podstawowym czynnikiem kształtowania turystyki poznawczej. Kultura popularna udostępniła szerokim masom społeczeństw wiele dziedzin kultury wysokiej, do której do tej pory nie miały one dostępu lub był on ograniczony. W ten sposób także dziedzictwo kulturowe śmierci zostało upowszechnione i uznane za walor turystyczny. Zmieniający się charakter konsumpcji turystycznej zadecydował o odkrywaniu przez turystów nowych przestrzeni, choć wielokrotnie znanych wcześniej, to stosunkowo słabo rozpoznanych.

Turystyka jest zjawiskiem złożonym i wielopłaszczyznowym, obejmującym wiele dziedzin życia poszczególnych osób i zbiorowości ludzkich i można ją rozpatrywać w kilku aspektach (KUREK, red. 2008, s. 17) opisujących również możliwości wykorzystania przestrzeni śmierci na potrzeby turystyki:

- jako zjawisko psychologiczne, odnoszące się do człowieka (potrzeby, motywy, cele, wyobrażenia, zachowania, przeżycia);

- jako zjawisko kulturowe, ponieważ jest funkcją turystyki, w turystyce dochodzi do interakcji kulturowej;

- jako zjawisko społeczne, obejmujące relacje interpersonalne, styczności społeczne i wynikające $\mathrm{z}$ tego skutki dla stron kontaktu;

- jako zjawisko przestrzenne, obejmujące zagospodarowanie turystyczne i przestrzenny charakter migracji turystycznych determinujących określone zmiany w przestrzeni geograficznej; 
- jako zjawisko ekonomiczne, w którym dochodzi do kontaktu między wytwórcą a odbiorcą dóbr turystycznych, co powoduje określone skutki ekonomiczne.

Turysta poszukując doznań odmiennych od tych, które towarzyszą mu w codziennym życiu staje się konsumentem produktów turystycznych korzystającym z walorów przestrzeni geograficznej, z czasem przygotowanych w odpowiedni sposób do turystycznego odbioru. Również śmierć $\mathrm{w}$ aspekcie ontologicznym i fenomenologicznym wzbudza ciekawość poznawczą, wynikającą m.in. z eschatologicznych zainteresowań człowieka.

Podróże turystyczne, w ramach których odwiedzane są przestrzenie śmierci nazwano tanatoturystyką ${ }^{1}$ (SEATON 1996, TANAŚ 2006a). Tanatoturystykę można uznać za swego rodzaju pomost pomiędzy śmiercią a życiem, pomiędzy umarlymi a żywymi. Turysta jest zachęcany do kontemplacji śmierci mającej wymiar nie tylko religijny, ale również, a może przede wszystkim, społeczny. Śmierć wzbudza zarówno lęk, respekt, jak i zdystansowany uśmiech. Turystyka jest $\mathrm{w}$ stanie wygenerować każdy $\mathrm{z}$ zamierzonych skutków, w zależności od potrzeb i zasobów, jakimi dysponują i turyści, i organizatorzy atrakcji turystycznych. Popkulturowe i rozrywkowe produkty turystyczne wielokrotnie wykorzystują aspekt śmierci, jej obraz i symbolikę w celu wywołania określonych wrażeń i emocji. Zamki strachu, muzea śmierci, inscenizacje egzekucji i tortur, podróże do stref zagrożenia życia są niewątpliwie przykładem diametralnie innego, $\mathrm{w}$ ocenie wielu kontrowersyjnego lub nieprzyzwoitego, wykorzystania przestrzeni śmierci do celów komercyjnych.

Niezależnie, czy w wymiarze kultury wysokiej czy popularnej zawsze przekaz płynący do turysty ma dla niego wymierne znaczenie. Tanatoturystyka, stanowiąca rodzaj turystyki kulturowej, wpływa na poszerzenie świadomości społecznej, odkrywanie dziedzictwa przez przekraczanie granic kulturowych, rozbudzanie rozmaitych potrzeb, identyfikację, wartościowanie oraz interpretację kultur. Kontakt z przestrzenią śmierci może być dla turysty stymulujący, poprzez odkrywanie nieznanego dla niego świata, wielokrotnie niezrozumiałego i rodzącego obawy. Nieobecność śmierci w prywatnym życiu, ze względu na redukcję życia religijnego i postępującą sekularyzację społeczeństw, medykalizacje procesu umierania i komercjalizację

1 Autor w artykule Tanatoturystyka - kontrowersyjne oblicze turystyki kulturowej (TANAŚ 2006a) wprowadził termin "tanatoturystyka" (Tanatos + turystyka; analogicznie funkcjonują $\mathrm{w}$ języku polskim pojęcia tanatofobia, tanatologia), będący polskim odpowiednikiem angielskiego terminu thanatourism (SEATON 1996). Tanatoturystyka to podróże turystyczne do przestrzeni śmierci; dokładniej zdefiniowana została w rozdziale 5. 
śmierci obserwowaną w branży pogrzebowej, stoi w opozycji do wszechobecności drastycznej śmierci w kulturze popularnej i mediach.

Paradoksalnie tanatoturystyka odgrywa istotną rolę $w$ relacjach między sacrum a profanum śmierci, jest czynnikiem wywołującym zainteresowanie śmiercią $w$ różnych aspektach jej rozumienia oraz postrzegania - zarówno edukacyjno-wychowawczym, jak i pogłębiającym tabu śmierci, poprzez upowszechnianie fikcyjności śmierci $\mathrm{w}$ wytworach kultury popularnej. Tanatoturystyka pozwala na zrewidowanie podejścia turysty do śmierci, stymulując proces tanatopsji ${ }^{2}-\mathrm{z}$ pierwotnego poczucia strachu i odrazy do zrozumienia i przygotowania się na śmierć. Również turystyczne atrakcje, bazujące na fenomenie śmierci, poprzez rozrywkę, edukację, upamiętnienie, mogą zmniejszać obawy przed śmiercią (STONE 2012).

Zapoczątkowane $\mathrm{w}$ Polsce przez autora badania nad tanatoturystyką, której pierwotnym przedmiotem poznania były cmentarze (TANAŚ 2004, 2008b), mają swoją kontynuację w postaci licznych opracowań problematyki wykorzystania przestrzeni śmierci na potrzeby turystyki, opublikowanych przez autora i cytowanych $\mathrm{w}$ literaturze przedmiotu. Tym samym został określony ogólny cel badań, jakim jest zidentyfikowanie i opisanie podróży turystycznych do przestrzeni śmierci nazwanych tanatoturystyką (TANAŚ 2006a), wpisujący się w nurt badawczy nad szerzej rozumianą mroczną turystyką, określoną w literaturze angielskiej jako dark tourism ${ }^{3}$ (LENNON, FOLEY 2000, STONE 2006).

Opierając się na wielu przykładach autor podjął próbę teoretycznego opracowania mechanizmów wymuszających potrzebę turystycznego podróżowania do przestrzeni śmierci, rozumianej jako wyodrębniona z przestrzeni geograficznej przestrzeń determinowana śmiercią (TANAŚ 2006b). Przestrzeń śmierci to przestrzeń realna o charakterze przedmiotowym i podmiotowym (LISOWSKI 2003, s. 42). Ujęcie heteroteliczne przypisuje przestrzeń

2 Punktem wyjścia do rozważań nad tanatoturystyką jest tanatopsja, czyli kontemplacja śmierci (SEATON 1996). Angielskie thanatopsis - rozmyślanie, kontemplacja śmierci wywodzi się z połączenia greckich słów Tanatos (bóg śmierci) i opsis (widok, wygląd) (The Oxford English Dictonary 1991, BAŃKO 2003). Tanatopsja rozpowszechniona została w społeczeństwie europejskim przez Kościół chrześcijański, który w sztuce i kulturze bardzo często nawiązywał do wyobrażenia śmierci. Była religijną i polityczną regułą, formą duchowego przygotowania na śmierć, swego rodzaju memento mori (z łac. „pamiętaj o śmierci”), zachęcając społeczeństwo do lepszego życia (porównaj: TANAŚ 2006a).

${ }^{3}$ Po raz pierwszy pojęcie dark tourism (ciemna, mroczna, ponura turystyka) opisali i zdefiniowali M. FOLEY i J. LENNON (1996) jako zjawisko obejmujące podróże do miejsc katastrof, morderstw, masowych śmierci i ludobójstw. Autor w dotychczas publikowanych pracach w odniesieniu do pojęcia dark tourism używał terminu "ciemna turystyka". Ze względu na charakter podróży turystycznych do miejsc wzbudzających lęk, przerażenie i opór wydaje się, że „mroczna turystyka” w języku polskim trafniej oddaje sens terminu dark tourism. 
jako zbiór przedmiotów (artefaktów) do określonych podmiotów (ludzi) poznających ją, działających w niej lub kształtujących ją. Uwzględnienie człowieka, jako podmiotu działającego w rzeczywistym świecie fizycznym i w określonych realiach przestrzenno-czasowych, wskazuje na analizę przestrzeni śmierci i przestrzeni turystycznej w kategoriach subiektywnych, wewnętrznych doświadczeń, określonych potrzeb i wyobrażeń. Przestrzeń śmierci jest identyfikowana przez człowieka dzięki jego pamięci. Jeżeli fakt związany ze śmiercią ulega zatarciu w ludzkiej pamięci w wyniku zapomnienia, to w przestrzeni geograficznej również traci swoje miejsce. Nie możemy wówczas identyfikować tej przestrzeni jako przestrzeń śmierci.

W następstwie podróży turystycznych do przestrzeni śmierci następuje rozwój przestrzeni turystycznej, rozumianej jako część przestrzeni geograficznej i społecznej, w której zachodzą zjawiska turystyczne, niezależnie od wielkości i charakteru ruchu turystycznego (WARSZYŃSKA, JACKOWSKI 1978, LISZEWSKI 1995, LATOSIŃSKA 2006, WŁODARCZYK 2009). Przestrzeń turystyczna jest identyfikowana przez człowieka dzięki jego działaniu. Innymi słowy, jeżeli w przestrzeni geograficznej nie rejestrujemy ruchu turystycznego, nie możemy mówić o przestrzeni turystycznej.

Zmienną opisującą przestrzeń śmierci i przestrzeń turystyczną jest czas. Nawiązując do badań nad przestrzenią turystyczną, wyodrębnioną z przestrzeni geograficznej (LISZEWSKI 2006, WŁODARCZYK 2009), autor podejmuje badania nad ewolucją przestrzeni śmierci będącą początkowo przestrzenią nieturystyczną, która pod wpływem działalności człowieka oraz przemian kulturowych może zostać zaklasyfikowana jako przestrzeń turystyczna lub stanowić jej część. Jednym z głównych celów badań nad tanatoturystyką jest określenie przestrzennej i kulturowej specyfiki opisywanych podróży $\mathrm{w}$ oparciu o założenia geografii kultury (OTOK 1986, ORŁOWSKA, red. 2002, REMBOWSKA 2002b, MYGA-PIĄTEK 2005) i geografii turyzmu (WARSZYŃSKA, JACKOWSKI 1978, KOWALCZYK 2000).

Geografia kultury obejmuje badania przestrzennych aspektów kultury, w tym m.in. rozpoznawanie przestrzennych artefaktów jako form interpretacji zachowań i znaczeń poszczególnych jednostek lub grup społecznych, interpretacje przestrzeni kulturowych, badanie przestrzeni doświadczanych i odczuwanych, tożsamości przestrzennej czy krajobrazu symbolicznego i kulturowego (REMBOWSKA 2002b). Z kolei geografia turyzmu koncentruje się na studiach nad przydatnością przestrzeni geograficznej do potrzeb ruchu turystycznego, postawami turystów wobec określonych form i sposobów uprawiania turystyki, procesami zachodzącymi w przestrzeni geograficznej pod wpływem zjawisk turystycznych i organizacją przestrzenną turystyki (LISZEWSKI 1981, WARSZYŃSKA 1999). Wobec tego proces przekształca- 
nia przestrzeni śmierci w przestrzeń turystyczną mieści się zarówno w problematyce badań geografii turyzmu, jak i geografii kultury.

Problem badawczy można sformułować $\mathrm{w}$ postaci pytania: jakie jest znaczenie śmierci $\mathrm{w}$ procesie kształtowania przestrzeni turystycznej? Odpowiedź na nie polega m.in. na zidentyfikowaniu i opisaniu procesu poszerzania przestrzeni turystycznej o nowe przestrzenie, pierwotnie uznawane za nieturystyczne, ściśle korelując je z problematyką badawczą geografii turyzmu i geografii kultury. Jest to opis i analiza:

- relacji przestrzeni śmierci z przestrzenią turystyczną (funkcji, organizacji i użytkowania);

- możliwości i sposobów wykorzystania przestrzeni śmierci w turystyce kulturowej;

- geograficznego zróżnicowania kultury śmierci.

Przedmiotem podjętych badań jest istota - geneza, ewolucja i determinanty zmian - przestrzeni śmierci stanowiącej cel podróży turystycznych. Przestrzeń śmierci obejmuje materialne i niematerialne elementy gromadzone $\mathrm{w}$ ciągu dziejów - związane $\mathrm{z}$ upamiętnieniem śmierci $\mathrm{w}$ przestrzeni geograficznej oraz z działaniami, efektem których jest śmierć - zwane dalej kulturą śmierci. Wyodrębniona przez człowieka (turystę) z przestrzeni geograficznej przestrzeń śmierci, która pod wpływem ruchu turystycznego podlega zmianom funkcjonalnym, stając się przestrzenią tanatoturystyki, będzie traktowana jako podmiot badań (rys. 1).

PRZESTRZEŃ GEOGRAFICZNA

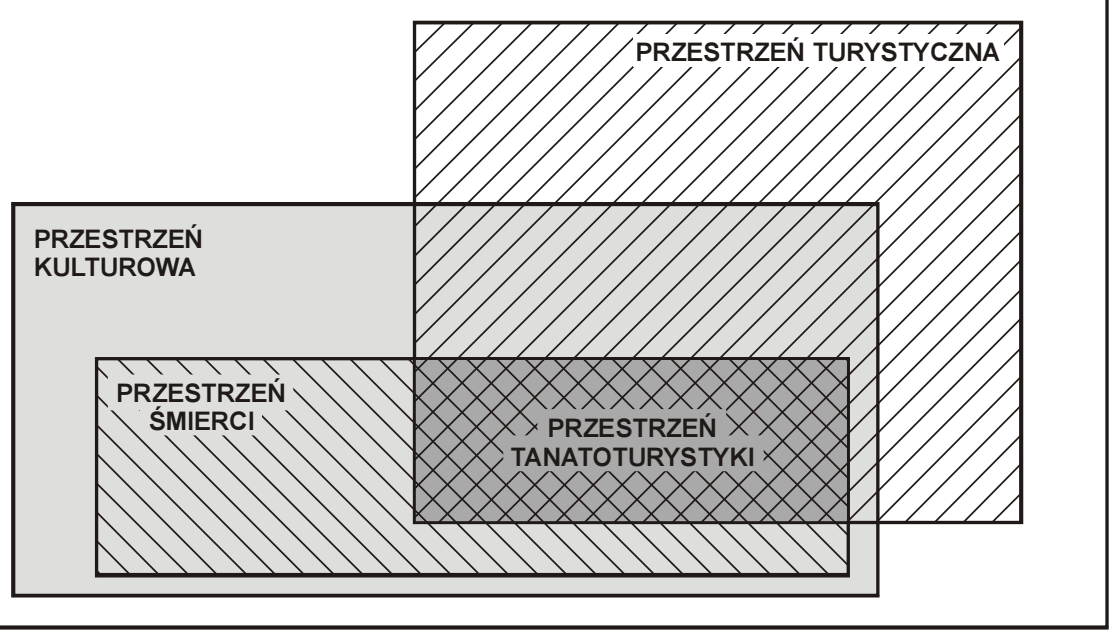

Rys. 1. Miejsce przestrzeni tanatoturystyki w przestrzeni geograficznej Źródło: opracowanie własne 
W centrum zainteresowania autora znalazły się te elementy kultury, które są powiązane $\mathrm{z}$ definiowaną przez niego śmiercią $\mathrm{w}$ ujęciu geograficznym, społecznym, kulturowym i religijnym. Można wyodrębnić kilka modelowych postaw człowieka wobec śmierci (JACKOWSKI 1986, SZEWCZYK-KOWALCZYK 2012):

- śmierć jest tylko granicą między bytem doczesnym a wiecznym; aby zasłużyć na lepszy byt lub byt wieczny trzeba żyć godnie; śmierć jest egzaminem (śmierć jest elementem wiary, religii);

- śmierć jest końcem jednostkowej egzystencji; życie przekazane jest w potomstwie; człowiek jest częścią rodziny, społeczności, kultury (śmierć jest elementem tożsamości);

- śmierć jest końcem życia; zostaje tylko pamięć o człowieku i ślad po jego działalności, dlatego trzeba tak żyć, żeby zasłużyć na pamięć (śmierć jest elementem pamięci, wyrazem patriotyzmu, męczeństwa, chwały);

- śmierć jest końcem wszystkiego; trzeba cieszyć się życiem i je konsumować; życie jest dobrem najwyższym (śmierć jest odrzucona, ironizowana, symbolicznie jest elementem rozrywki).

Śmierć na potrzeby niniejszej pracy definiowana jest jako ontologiczny kres życia (CHABANIS 1987, JAWORSKI 1979) zarówno podmiotowego - kogoś, jak i przedmiotowego - czegoś, identyfikowany przez system znaków (symboli) oraz artefakty kształtowane i gromadzone w procesie ewolucji i dyfuzji kultur. M. HEIDEGGER (1994) pojmował śmierć jako kres, jako dopełnienie, dzięki któremu możliwa jest egzystencjalna pełnia (SZABAT 2012). Śmierć, w pewnym sensie, według M. HEIDEGGERA (1994) kształtuje sposób bycia. Śmierć jest rozpatrywana przede wszystkim przez pryzmat nagromadzonych wartości kulturowych (materialnych i niematerialnych) stanowiących dziedzictwo cywilizacyjne wartościowane przez pamięć o nim, która rodzi się wraz z kresem życia.

Główne założenia przyjęte w pracy, pozwalające ująć problem badawczy $\mathrm{w}$ określone ramy teoretyczne pozostające $\mathrm{w}$ nurcie geografii społeczno-ekonomicznej, są następujące:

- ujęcie geograficzne pracy odwołuje się do szeroko rozumianej humanistycznej koncepcji geografii kultury, z wykorzystaniem dialektycznej teorii rzeczywistości społeczno-kulturowej łączącej możliwości analizy obiektywnych i subiektywnych przejawów życia społecznego (REMBOWSKA 2002b) oraz geografii turyzmu;

- badania nad kulturowymi aspektami życia społecznego są determinowane historyczną (czasową) zmiennością i geograficznym (przestrzennym) zróżnicowaniem; 
- przestrzeń śmierci jest wewnętrznie zróżnicowana i dynamiczna;

- przestrzeń turystyczna jest przestrzenią relacyjną (turysta-przestrzeń), rozumianą jako indywidualna przestrzeń turystyczna (przestrzeń turystyczna człowieka) będąca sumą przestrzeni, w których aktywność turystyczną przejawia jednostka lub grupa ludzi. W określonych sytuacjach przestrzeń turystyczna będzie również związana z konkretnym terytorium - przestrzeń turystyczna obszaru, mająca wyznaczone granice (WŁODARCZYK 2009).

Mając na uwadze problem badawczy, przedmiot badań i założenia przyjęto następującą hipotezę: śmierć definiowana w kategoriach biologicznych i kulturowych jest czynnikiem kształtującym przestrzeń geograficzną, a w szczególności wyodrębnioną z niej przestrzeń turystyczną. Dodatkowo autor stawia tezy pomocnicze:

- sposób organizacji przestrzeni śmierci wynikający z przyjętych norm kulturowych jest czynnikiem kształtującym zainteresowanie człowieka wobec niej;

- przestrzeń śmierci ma walory religijne, edukacyjne, wychowawcze, socjalizacyjne i emocjonalne;

- rozwój kultury popularnej spowodował wzrost postmodernistycznego zainteresowania przestrzenią śmierci, w konsekwencji czego nastąpił rozwój produktów turystycznych wykorzystujących składowe tej przestrzeni;

- geograficzne zróżnicowanie przestrzeni śmierci i jej interpretacji jest czynnikiem determinującym tanatoturystykę.

Celem pracy jest weryfikacja postawionych tez, a zatem:

- identyfikacja przestrzeni tanatoturystyki;

- określenie istoty i klasyfikacja tanatoturystyki;

- identyfikacja i charakterystyka czasoprzestrzenna kultury śmierci i poznawczego zainteresowania nią człowieka podróżującego;

- identyfikacja i charakterystyka procesów prowadzących do ewolucji przestrzeni śmierci z nieturystycznej w turystyczną;

- próba określenia geograficznej koncepcji badań przestrzeni śmierci.

W naukach zajmujących się przyczynami i skutkami ruchu turystycznego nurt badawczy obejmujący studia nad wykorzystaniem przestrzeni śmierci w turystyce jest stosunkowo młody, a badania identyfikujące tanatoturystykę są prowadzone na pewno od połowy lat dziewięćdziesiątych XX wieku. W Polsce brak jest opublikowanych kompleksowych badań nad opisywanymi zagadnieniami z zakresu geografii turyzmu, poza pracami obejmującymi badania turystycznego wykorzystania przestrzeni cmentarzy (TANAŚ 2008b). 
W celu zgłębienia postawionego problemu badawczego należy sięgnąć do literatury z zakresu m.in. geografii człowieka (JĘDRZEJCZYK 1997, 2006, LISOWSKI 2003), geografii turyzmu (LISZEWSKI 1981, KOWALCZYK 2000), geografii czasu (MAZURKIEWICZ 1994, HEIDEGGER 2004, KACZMAREK 2005), geografii kultury (REMBOWSKA 2002b) i geografii religii (JACKOWSKI 2003). $\mathrm{W}$ wymienionych subdyscyplinach geografii przestrzeń śmierci (TANAŚ 2006b) może być badana i analizowana $\mathrm{w}$ wymiarze relacji człowieka $\mathrm{z}$ przestrzenią geograficzną.

Przestrzenie napiętnowane śmiercią $\mathrm{w}$ badaniach tanatologicznych, antropologicznych, historycznych i socjologicznych mają swoje miejsce od dawna, ale studia nad przestrzenią śmierci, będącą częścią przestrzeni kulturowej (HOWETT 1977, KONG 1999, TANAŚ 2006a,b, 2011a) i stanowiącą przedmiot badań $\mathrm{w}$ ramach geografii kultury, mają korzenie w geografii w latach sześćdziesiątych XX wieku. Został wówczas zapoczątkowany nurt badań nad układem przestrzennym cmentarzy amerykańskiej szkoły nekrogeografii (KNIFFEN 1967, FRANCAVIGLIA 1971, HECKEL 1972, NAKAGAWA 1987, TREMLETT 2007, HUPKOVA 2008).

Autor sięgnął do licznych publikacji, cytowanych w dalszej części pracy, z zakresu studiów nad mroczną turystyką (dark tourism) i tanatoturystyką (thanatourism), w ramach których pojawiło się wiele publikacji cząstkowych. W literaturze przedmiotu odnaleźć można wyniki dociekań naukowych nad turystycznymi motywami i doświadczeniami związanymi z mroczną turystyką i tanatoturystyką (m.in. DANN 1998, LENON, FOLEY 2000, SEATON, LENON 2004, SHARPLEY 2005). Problematykę zarządzania atrakcjami tanatoturystycznymi i rozważania natury etycznej odnajdziemy w pracach A. SEATONA (2009), R. SHARPLEY'A (2009) i P.R. STONE'A (2009a). Turystyczna „konsumpcja" kultury śmierci, w perspektywie wyjaśnień tanatologicznych, podjęta została w publikacjach analizujących dark tourism (STONE 2005, 2008, 2011, 2012, SHARPLEY, STONE, red. 2009, SHARPLEY 2012). Badania te opierają się na tanatologicznym paradygmacie relacji między socjokulturowymi aspektami śmierci i śmiertelności, logicznych odpowiedziach na nieuniknioność ludzkiej śmierci i na potencjalnej roli turystyki w budowaniu relacji między światem żywych a światem umarlych. Próby konceptualizacji mrocznej turystyki i tanatoturystyki prowadzili jednak nieliczni (m.in. SEATON 1996, 2010, STONE 2006, 2010, SHARPLEY, STONE, red. 2009).

W Polsce badania nad zjawiskami mrocznej turystyki i tanatoturystyki są jak do tej pory spotykane stosunkowo rzadko. Prace obejmują najczęściej identyfikację tanatoturystyki i lokalne aspekty podróży do przestrzeni śmierci (TANAŚ 2006a, 2008b, 2012, MUSZEL 2007). Próby opisu mrocznej turystyki podejmowane były m.in. przez D. CHYLIŃSKĄ (2009) - przykład Dolnego 
Śląska, H. GRZESIAK (2011) - przykład Egiptu, I. MICHALSKĄ-DUDEK i R. PRZEOREK-SMYKA (2012) - przykład Smoleńska, A. KOMSTĘ (2013) - przykład Polski. Walory turystyki wojennej i militarnej na wybranych przykładach opisywali m.in. A. KOWALCZYK (2003, 2009a, b), T. JĘDRYSIAK i A.M. vON ROHRSCHEIDT (2011) oraz D. CHYLIŃSKA i G. KOSMALA (2011) - podając przykład potencjału historycznego wojen śląskich. Z kolei cmentarz, jako obiekt zainteresowań turystycznych był przedmiotem badań S. TANASIA $(2004,2008 b)$. Również przestrzeń sepulkralną jako walor turystyczny lub atrakcja turystyczna analizowano m.in. w pracach A. STASIAKA, S. TANASIA (2005), S. TANASIA (2007), A. WARTECKIEJ-WARZYŃSKIEJ (2010). Podróże poznawcze odbywane na cmentarze $\mathrm{w}$ ramach tzw. turystyki genealogicznej analizował R.T. PRINKE (2009). Zagadnienia podejmujące problematykę wykorzystania miejsc śmierci $\mathrm{w}$ turystyce kulturowej i dylematy etyczne $\mathrm{z}$ tym związane opisywały K. BUCZKOWSKA i E. MALCHROWICZ-MOŚKO (2012).

Realizacji przyjętych celów badawczych podporządkowano układ pracy, który obejmuje trzy zasadnicze zagadnienia: śmierć, geografię i turystykę, a człowiek i przestrzeń stanowią koncepcyjny fundament badań. Książka składa się z sześciu rozdziałów. W rozdziale pierwszym autor wyjaśnia koncepcję, cele pracy i założenia, wraz z krótką dyskusją terminologiczną oraz analizą wybranej literatury. Rozdziały drugi i trzeci obejmują zagadnienia związane $\mathrm{z}$ kulturowymi i geograficznymi aspektami śmierci. $\mathrm{W}$ rozdziale czwartym przedstawiona została rola człowieka w kształtowaniu przestrzeni tanatoturystyki. Rozdział piąty poświęcono wyjaśnieniu istoty tanatoturystyki. Rozdział szósty jest podsumowaniem rozważań na temat wykorzystania przestrzeni śmierci w turystyce.

Książka jest kolejnym etapem na drodze naukowej autora, który swoje zainteresowanie badawcze przestrzeniami śmierci rozpoczął od analizy walorów turystycznych cmentarzy wojennych (TANAŚ 2004), następnie podjął próbę konceptualizacji przestrzeni turystycznej cmentarzy (TANAŚ 2008b). Oddana do rąk Czytelnika książka jest próbą podsumowania wieloletnich badań nad wykorzystaniem przestrzeni śmierci w turystyce kulturowej z perspektywy geografii kultury i geografii turyzmu. 


\section{2. ŚMIERĆ I KULTURA}

Człowiek od najdawniejszych czasów, posługując się rozmaitymi wierzeniami i wartościami, kształtował postawy, oczekiwania i obawy związane ze śmiercią. Nieznane i niepokojące zjawisko stymulowało wyobraźnię człowieka, pobudzało do działań zarówno w nauce, jak i sztuce. Świadomość śmierci miała wpływ na kształtowanie reguł społecznego postępowania. Śmierć stała się formą represji wobec nieprzestrzegających norm religijnych, moralnych i prawnych.

Znaczącą rolę $\mathrm{w}$ kształtowaniu współczesnych postaw wobec śmierci i umieralności odegrały średniowieczne i późniejsze epidemie oraz wojny, w szczególności mające miejsce w XX wieku. Ludzie powojennej cywilizacji chcieli usunąć ze swej świadomości brutalną i gwałtowną śmierć (OSTROWSKA 1991, s. 27), czego efektem jest m.in. współczesna niechęć do rozmowy o śmierci. Pomimo unikania myśli o niej w sferze ogólnospołecznej ciągle wyzwala w człowieku emocje i reakcje, pobudza do refleksji i kształtuje określone postawy i zachowania.

Rozmyślanie o śmierci, „oswajanie” jej nie może być wulgarne, naiwne bądź nieszczere. Myśl o śmierci powinna uczyć pokory wobec życia własnego i życia innych. Z brakiem "oswojonej” śmierci łączy się w dużej mierze poczucie braku sensu życia, jego akceptacji oraz poczucia przynależności do świata w wymiarze społecznym (KAZIMIERCZAK 2012). Zmieniające się $\mathrm{w}$ historii i zróżnicowane geograficznie postawy wobec śmierci wykształciły materialne i duchowe dziedzictwo, wzbudzające u człowieka zarówno wieloaspektowe zainteresowanie, jak i niechęć wynikającą z obaw przed śmiercią, czego konsekwencją jest dystans i nieufność, jaką generuje kultura śmierci.

\subsection{ZMIENNOŚĆ INTERPRETACJI ŚMIERCI A TANATOTURYSTYKA}

W zależności od obszaru geograficznego, w którym zamieszkuje człowiek oraz postępu cywilizacyjnego zmieniały się poglądy i sposoby postępowania wobec śmierci, w szczególności w przypadku śmierci drugiego człowieka są 
zróżnicowane. Zmieniały się poglądy filozoficzne i religijne na temat kresu życia i samej śmierci, zmieniał się sposób postępowania $\mathrm{z}$ umierającymi i zmarłymi, zmieniała się obrzędowość żałobna, zmieniały się formy upamiętniania faktu śmierci i zmarlych. Ewolucja i zróżnicowanie geograficzne kultur, religii, tradycji czy norm prawnych kształtujących postawy człowieka wobec śmierci stały się źródłem zainteresowania kulturą śmierci, w następstwie czego zrodzily się motywy, których efektem są podróże do przestrzeni śmierci.

Na potrzeby wyjaśnienia roli, jaką odgrywa w tanatoturystyce postawa człowieka wobec śmierci, czego wyrazem jest geograficzne zróżnicowanie kultury śmierci, zostały wybrane dwie grupy wytworów kulturowych stanowiących podstawę współczesnego zainteresowania turystycznego kulturą śmierci. Są to wytwory kultury materialnej i postawy społeczne determinowane historią śmierci oraz problem tabu śmierci, który wywołał w XX wieku przekorne zainteresowanie poznawcze i rozrywkowe "zakazanym owocem", jakim jest kultura śmierci, kształtując współczesny rozwój tanatoturystyki.

\subsubsection{KRÓTKA HISTORIA ŚMIERCI}

Historia śmierci jest subdyscypliną historycznie traktowanej antropologii kultury (KOLBUSZEWSKI 1998, 2007). Analizy historycznej zmienności interpretacji śmierci wspomagać powinna geografia kultury, która lokuje w przestrzeni zjawiska kulturowe i pozwala na analizę ich przestrzennego zróżnicowania.

P. ARIÈS (2007) wprowadził rozróżnienie czasowe w interpretacji śmierci uzależnione od zmian w postawie człowieka wobec niej. Zastosowana przez niego próba historycznej klasyfikacji rytualizacji śmierci określa również zmiany, jakie zachodzily $\mathrm{w}$ zainteresowaniu poznawczym śmiercią przez człowieka podróżującego. Wyróżnił m.in. etapy śmierci zwyczajnej, oswojonej, powszechnej, własnej, zakwestionowanej, drugiego i wyklętej. Interpretacja śmierci miała znaczenie $\mathrm{w}$ kształtowaniu motywów podróży do miejsc dokumentujących i upamiętniających śmierć zarówno $\mathrm{w}$ aspekcie podmiotowym (człowieka, zwierzęcia, rośliny), jak i przedmiotowym (przestrzeni, miejsca, przedmiotu). M. VOVELLE (2004) wyodrębnił w europejskiej historii śmierci kilka etapów wynikających z postępujących zmian kulturowych:

a) dyskursy "magiczny" i „religijny" - przez długi czas jedyne akceptowane, trwające od starożytności po średniowiecze, wyróżniające się 
chrystianizacją śmierci i walką z magicznymi wierzeniami ludowymi, podczas których religia przejmowała pewne formy obrzędów pogańskich;

b) dyskurs „laicki”, który pojawiał się stopniowo, przybierając różne formy: filozoficzną, naukową, społeczną, doprowadzając do desakralizacji śmierci w dobie triumfu społeczeństw liberalnych;

c) dyskursy "literacki” i „artystyczny", które w najróżniejszych postaciach, aż po współczesność, poszerzają dotychczasowe tradycyjne ramy śmierci eksponując mistykę, irracjonalizm i deskrypcję niepokojów ${ }^{4}$.

Śmierć w Europie wczesnego średniowiecza można określić mianem "śmierci powszechnej" i „śmierci oswojonej”, co wynika z powszechności w tym czasie śmierci, która dziesiątkowała ludzkie zbiorowości. W tym okresie, z perspektywy podróży motywowanych religią i poznaniem, istotny był kult męczenników i świętych, którego początki udokumentowane zostały w starożytnej Afryce i Azji. Wędrówki do grobów „świętych mężów” były na tyle popularne $\mathrm{w}$ historii różnych religii, że determinowały lokalizację i rozwój sanktuariów, w których budowano wzniosłe świątynie, a wokół nich rozwijały się osiedla stanowiące zaplecze pielgrzymkowe (JACKOWSKI 2003, SOŁJAN 2012). Świątynie te z kolei, ze względu na zainteresowanie pochówkiem w bliskości świętego, przekształcały się w kościoły grobowe bądź $\mathrm{w}$ ich otoczeniu organizowano cmentarze. Również w kulturach judaistycznej i islamu powszechna do dziś jest tradycja grzebania w pobliżu grobów świętych (KOLBUSZEWSKI 1996).

W połowie epoki średniowiecza w kręgu zainteresowania społeczeństwa europejskiego znajdowała się „śmierć własna” podporządkowana dogmatom kościelnym. Była to śmierć cielesna, ponieważ zgodnie $\mathrm{z}$ regułą wielu religii dusza nie umiera, a wiara w nieśmiertelność duszy i życie wieczne jest wyznacznikiem wielu systemów religijnych. W XV i XVI stuleciu w europejskiej sztuce sepulkralnej i kościelnej dominował motyw Sądu Ostatecznego i sztuki umierania (ars moriendi). W kryptach kościelnych lub krużgankach cmentarnych organizowano ossuaria ${ }^{5}$. W sztuce i literaturze pojawił się trup personifikowany postacią kościotrupa i przedstawiany od XIV wieku w malarstwie w popularnym motywie "tańca śmierci" (danse macabre, totentanz). Przekonanie o nieśmiertelności duszy po śmierci ciała dominowało w społeczeństwie europejskim do XVI wieku. Średniowieczna powszechna wiara $\mathrm{w}$ nieśmiertelność pozwalała człowiekowi na wykształcenie $\mathrm{w}$ sobie goto-

\footnotetext{
${ }^{4}$ Porównaj: S. TANAŚ (2008b, s. 35-50).

${ }^{5}$ Ossuarium - z łac. ossuarius oznaczającego „kostny” - pomieszczenia, w których gromadzone są szczątki lub prochy zmarłych.
} 
wości do pogodzenia się ze śmiercią, zachęcała do podporządkowania się wyrokom boskim, bez podejmowania heroicznej walki z chorobą. Człowiek jednak obawiał się śmierci, a lęk przed nią i przed mękami duszy został skwapliwie wykorzystany przez ówczesnych moralistów w zachęcaniu do naprawiania błędów życia poprzez postępowanie zgodne z przyjętymi normami. Artystyczne wizje śmierci (szkielety, demony, piekło) budziły lęk, ale nie sprzeciw przed niekwestionowaną decyzją sił wyższych (OSTROWSKA 1991).

Odrodzenie przyniosło rewolucyjną zmianę w postawie człowieka wobec śmierci. Śmierć podporządkowana została koncepcjom świeckim. W wyniku desakralizacji śmierci, jako rytuału przejścia z życia doczesnego do wiekuistego, pojawił się strach wobec niej. Śmierć w ten sposób nabrała wymiaru moralizatorskiego. Traktowana była jawnie i naturalnie. $\mathrm{W}$ drugiej połowie XVII stulecia nastąpiła kolejna zmiana sposobu myślenia o śmierci. Oświecenie promowało intelekt, stojący wielokrotnie $\mathrm{w}$ opozycji do religijności. Wojny religijne przyczyniły się do wzrostu fanatyzmu i okrucieństwa, a wnioski płynące $\mathrm{z}$ nowożytnych odkryć nauki były początkiem rozwoju zlaicyzowanej koncepcji śmierci, znacznie trudniej akceptowalnej. Od XVI do XVIII wieku pojawiała się $\mathrm{w}$ Europie fascynacja śmiercią i cierpieniem. Ludzkie zwłoki stały się „wdzięcznym” tematem lekcji anatomii w takim stopniu, że tablice anatomiczne były cennym przedmiotem poszukiwań kolekcjonerów. Sekcje zwłok odbywały się poza salami wykładowymi nabierając cech widowiska, artyści wykorzystywali trupa jako główny motyw swoich dzieł, a prywatne osoby kolekcjonowały ludzkie organy (ARIÈS 2007, s. 159).

Pod koniec XVII stulecia fascynacja martwym ciałem stała się dyskretniejsza, by ponownie objawić się w wieku XVIII. Zmumifikowane ciało, wystawiane na widok publiczny, lub szczątki kostne, które wykorzystywano w budowaniu efektownych i jednocześnie makabrycznych dekoracji kościelnych, stanowily część późnobarokowej sztuki sepulkralnej. Wytwory tej sztuki można najczęściej obserwować w ossuariach, które w historii były odwiedzane szczególnie przez wiernych i pielgrzymów zarówno z motywów religijnych, jak i widowiskowych, a współcześnie przez rzesze turystów zainteresowanych barokową makabrą. Scenerie kostne można oglądać w kryptach wielu kościołów na całym świecie. W Europie najczęściej odnajdziemy je w kościołach i klasztorach, m.in. kapucynów i franciszkanów. Przykładem tego typu świątyń są XVI-wieczny kościół pw. Santa Maria dell'Orazione e Morte w Rzymie, będący znanym rzymskim ossuarium zorganizowanym przez zakon kapucynów, kościół cmentarny pw. Wszystkich Świętych w Kutnej Horze (fot. 1) czy Kaplica Czaszek w polskiej Czermnej (Kudowa Zdrój). 


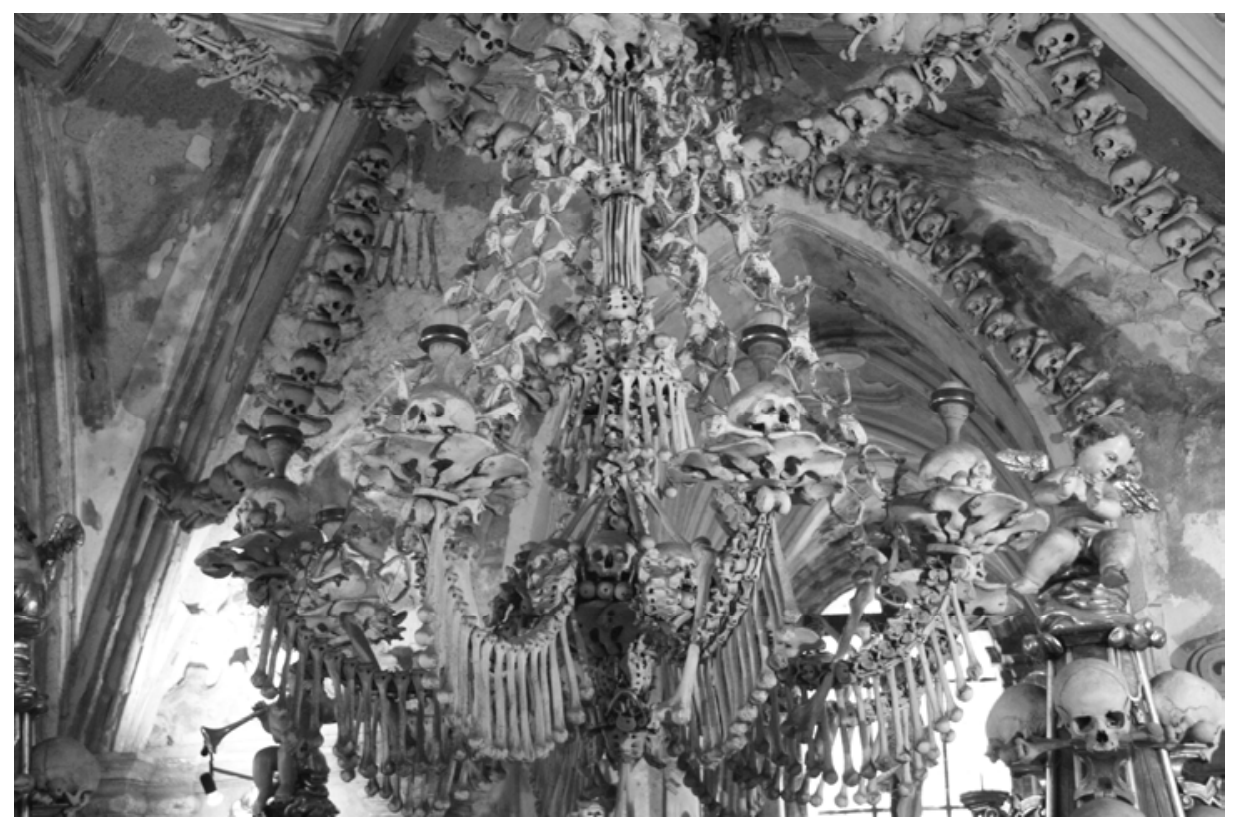

Fot. 1. Siedemnastowieczna dekoracja kościoła cmentarnego pw. Wszystkich Świętych w Kutnej Horze - Czechy

(autor: S. Tanaś)

Od XVIII wieku możemy mówić o „śmierci drugiego”. Uczucie smutku po odejściu bliskiej osoby rodziło w Kościele katolickim kult grobu. Z kolei kult zmarłego można było wiązać z wydarzeniami historycznymi mającymi miejsce od XVIII stulecia - kiedy upowszechnił się kult bohatera, łączony z budującymi się w tym czasie postawami patriotycznymi wielu narodów Europy - manifestowanymi w przestrzeni geograficznej poprzez pomniki i cmentarze zasłużonych. Również w Polsce "śmierć narodowa”, będąca zawsze śmiercią tragiczną, odegrała istotną rolę $\mathrm{w}$ kreowaniu przestrzeni pamięci narodowej i budowaniu postaw patriotycznych. Jednocześnie polska „śmierć za ojczyznę" zawiera aspekt wybitnie geograficzny (KOLBUSZEWSKI 2008, s. 11). Lokalizacja przestrzeni i miejsc, w których Polacy padali ofiarą tak postrzeganej śmierci, jest rozproszona, skomplikowana i trudna do zewidencjonowania. Lokalizacja więzień (np. Pawiak), miejsc zsyłki (np. Syberia), miejsc straceń (np. Palmiry, Katyń), obozów koncentracyjnych (np. Auschwitz, Treblinka, Dachau) czy cmentarzy wojennych (np. Narwik, Monte Casino) jest związana z walką Polaków i śmiercią "za naszą i waszą wolność" na wielu frontach świata, co sprzyja współcześnie narodowym pielgrzymkom i podróżom o podłożu patriotycznym. 
Po średniowiecznej więzi żyjących ze śmiercią i zmarłymi oraz po barokowej fascynacji makabrą w XIX wieku nastąpił okres strachu przed śmiercią, niechęć do jej przedstawiania i wyobrażania. Odraza realnością śmierci w sztuce została w tym czasie złagodzona przez próby jej upiększenia. Wizja erotyzmu makabrycznego przedostała się do życia codziennego, wyzbywając się brutalnych cech i przybierając wysublimowaną postać cielesnej urody zmarłego. Lęk przed śmiercią wymusił zakaz wizerunku odrażającej śmierci. Już w XIX wieku śmierć stała się wstydliwa. P. ARIÈs (2007) czas ten określił mianem „śmierci wyklętej”. Uważano wówczas, że społeczeństwo winno być chronione przed zmartwieniem i nadmiernym wzruszeniem, jakie wywołuje śmierć, obecna pośród pozornie szczęśliwego życia.

W XX wieku śmierć została odizolowana od żywych. Trauma I i II wojny światowej oraz medykalizacja śmierci zmienily jej wizerunek. Przestała być rytualną ceremonią, której przewodzi umierający w otoczeniu rodziny i przyjaciól. Śmierć stała się zjawiskiem "technicznym”. G. GORER (1979) zwracał uwagę na wykluczenie w XX wieku śmierci z dyskursu społecznego przez erotyzm, wprowadzając określenie „pornografia śmierci”. Częściej mówiło się w kulturze zachodniej o erotyzmie, który przestał być tematem tabu, rzadziej o śmierci, która nabrała jego cech. Im bardziej społeczeństwo uwalniało się od ograniczeń dotyczących erotyzmu, tym silniej odrzucało wszelkie sprawy związane ze śmiercią. W ten sposób po kilku wiekach, w których śmierć była publicznym widowiskiem, przed którym nikomu nie przyszłoby na myśl się uchylać, pojawiło się tabu śmierci. Potrzeba szczęścia, moralny obowiązek i społeczny nakaz przyczynienia się do szczęścia ogółu przez usuwanie wszelkich powodów do smutku czy zmartwienia były powodem odrzucenia śmierci z umysłów ludzkich. Człowiek, posługując się wierzeniami, wartościując i obserwując śmierć innych wykształcił swoje własne nadzieje i obawy. W krajach, które zachowały bardziej tradycyjną rolę religii w społeczeństwie stosunek do spraw związanych ze śmiercią jest współcześnie bardziej otwarty, a symbole i myśli o śmierci częściej obecne. Przykładem na to jest Dzień Wszystkich Świętych i Dzień Zaduszny w Polsce, kiedy życie społeczne koncentruje się wokół cmentarzy i zmarłych, lub Dzień Zmarłych w Meksyku, gdzie szkielety, czaszki i piszczele pojawiają się jako dekoracja grobowa, a nawet $\mathrm{w}$ formie wyrobów cukierniczych i pamiątek turystycznych.

Współcześnie śmierć stała się przedmiotem potocznego przekazu medialnego o randze zbliżonej do widowiska sportowego, koncertu czy wydarzenia politycznego. Jej wartość medialna wzrasta, gdy jest wieścią sensacyjną i wstrząsającą $\mathrm{w}$ takim stopniu, w jakim może $\mathrm{w}$ określonym czasie zwiększyć oglądalność, słuchalność lub poczytność. Śmierć stała się towarem 
podlegającym prawom rynkowym, podobnie jak każdy inny produkt kultury masowej (ADAMKIEWICZ 2004).

W tym miejscu należy wspomnieć o sposobie podejścia do śmierci $\mathrm{w}$ innych niż europejska kulturach. Właściwie kultury judeo-chrześcijańskie i islamskie traktują śmierć podobnie - jest to etap na drodze do życia wiecznego, którego osiągnięcie uzależnione jest od wypełniania przykazań bożych w życiu doczesnym, a celem jest zbawienie i osiągnięcie raju. Różnice są wyraźne w obrzędowości, rytuale pogrzebowym oraz formie upamiętnienia zmarłego i determinowane są czynnikami geograficznymi, w szczególności strefą przyrodniczą i klimatyczną, w której ulokowana jest określona kultura. Ma to również odzwierciedlenie w organizacji cmentarzy i mogit.

Odmiennie śmierć jest traktowana w kulturach Azji Południowo-Wschodniej. Zarówno hinduizm, jak i buddyzm traktują śmierć jako etap w przejściu do kolejnego życia przez reinkarnację. Droga ta kończy się bądź połączeniem z Bogiem, bądź osiągnięciem Nirwany. Hinduizm i buddyzm wraz z ich odłamami nakazują kremację lub inny sposób pochówku, lecz z wyłączeniem grzebania ciała w ziemi, stąd w krajobrazie niektórych obszarów Azji (np. Indii, Tybetu, Mongolii) brak jest cmentarzy, a powszechne są stosy ciałopalne lub miejsca porzucania ciał na pożarcie przez ptaki lub inne zwierzęta (KRAMER 2006).

Podobnie pozostałe religie lub wierzenia traktują śmierć najczęściej jako etap w życiu duszy i nieodwracalny koniec cielesnego życia. Należy pamiętać, że w krajach afrykańskich, na wielu obszarach Azji, Ameryki i w Australii poszczególne grupy etniczne mają własne koncepcje śmierci oraz normy postępowania wobec niej i wobec zmarlych wynikające $\mathrm{z}$ wielowiekowej izolacji kulturowej. Różnice kulturowe i geograficzne w postrzeganiu śmierci i jej rytualizacji decydują współcześnie o poznawczym zainteresowaniu śmiercią.

\subsubsection{TABU ŚMIERCI}

Problem śmierci i śmiertelności stał się w ostatnich latach ponownie przedmiotem zainteresowania społecznego, w konsekwencji również turystycznego. Zainteresowanie to może wynikać $\mathrm{z}$ dyskusji nad wieloma aspektami śmierci, z którymi współczesny człowiek musi się mierzyć. Problematyka eutanazji, aborcji, kary śmierci, zbrodni, ludobójstwa, zamachów, wypadków, tragicznych zdarzeń czy wiary w życie pozagrobowe wielokrotnie ma wpływ na zainteresowanie człowieka śmiercią, którą współcześnie rozwinięte społeczeństwa właściwie odrzucają, tym samym uciekając od wizji własnej 
tymczasowości. Dozwolona prawem w niektórych państwach eutanazja wywołuje migracje ludzi będących u kresu życia, którzy za własną zgodą pragną skrócenia cierpienia i śmierci. W mediach pojawiły się określenia, które dla zainteresowanych i badających zjawisko turystyki są nie do przyjęcia, niemające żadnych podstaw etymologicznych, aby łączyć eutanazję czy aborcję z turystyką - "turystyka eutanazyjna", ,"turystyka aborcyjna", ,turystyka śmierci". Trudno rozpatrywać problem eutanazji i aborcji w kategoriach podróży turystycznych, choć z perspektywy medycyny, filozofii, antropologii kultur czy popularnego przekazu jest to zjawisko dyskutowane (PAKES 2003, COGGON, HOLM 2007, LUNT, CARRERA 2010).

W literaturze przedmiotu można spotkać się z tezą, zgodnie z którą dzisiejszy człowiek wyparł śmierć ze swojej świadomości. Teza ta jest jednak krytykowana przez tych autorów, którzy twierdzą, że pojawiło się jedynie nowe rozumienie śmierci, oparte na nauce i dostosowane do racjonalnie myślącego społeczeństwa. M. SCHELER (1994) uważa, że podejście współczesnego człowieka do śmierci i zanikanie wiary w nieśmiertelność w kręgu kultury zachodnioeuropejskiej mają uzasadnienie $\mathrm{w}$ zmianie stosunku do doświadczenia śmierci, wynikającego również $\mathrm{z}$ „rachunkowego podejścia w prowadzeniu życia” i wszechobecnej kalkulacji. Brak kontemplacji „rozkoszy z Bogiem i ciałem” jest konsekwencją „,zimnej kalkulacji i przymusu pracy" wynikających z postępu, co czyni człowieka w szczególny sposób niewrażliwym na myśl o śmierci (SCHERER 2008, s. 27). Jest to wyidealizowana ocena "poznania”, z góry określającego „istnienie” - to czego nie jesteśmy w stanie poznać, nie istnieje.

O doświadczeniu śmierci pisał M. HEIDEGGER (1994) zwracając uwagę na interpretację śmierci w „byciu ku śmierci” lub „byciu ku kresowi” (SZABAT 2012). Śmierć jest przypadkiem, zdarzeniem występującym wewnątrz świata. Gdy umiera człowiek, nie umiera jego "ja". Podejście Heideggera do śmiertelności i umierania może tłumaczyć złożoność lub prostotę zachowań tanatoturystycznych człowieka, któremu chodzi tylko o "możność bycia”, tym samym wypierając z jestestwa myśl o śmierci (HEIDEGGER 1994, s. 355358). Doświadczenie śmierci kogoś innego, może nawet bliskiego, choć niekoniecznie, przynosi świadomość bycia częścią wspólnoty śmiertelnych i perspektywę jej przeżywania (JANKELEVITCH 1993, s. 53-54). Śmierć jest ciągle obecna w naszym życiu, znaczy to, że tajemniczość otaczająca śmierć skrywa przed nami sens całej naszej egzystencji (HEIDEGGER 1994). Egzystencjonalne znaczenie śmierci - „byt ku śmierci” - jest otwarciem na byt poprzez właściwe pojmowanie śmierci, często $\mathrm{w}$ emocjonalnym stosunku do niej. Lęki i obawy decydują o unikowych zachowaniach wobec wszystkiego, co dotyczy śmierci lub ją przypomina. 
Z. BAUMAN (2007) zwraca uwagę, że kultura doby płynnej nowoczesności, w odróżnieniu od kultur znanych z opisów historycznych i etnograficznych, nie jest już kulturą nabywania wiedzy i akumulacji doświadczeń. Jest raczej kulturą niezaangażowania, nieciągłości i zapomnienia. B. PASCAL (1996, s. 106-107) zauważyl, że ludzie „nie mogąc znaleźć lekarstwa na śmierć [...], postanowili - aby osiągnąć szczęście - nie myśleć o niej. Łatwiej znieść śmierć bez myśli o niej, niż myśl o śmierci bez niebezpieczeństwa". Śmierć zniknęła z horyzontu współczesnego człowieka, stała się niewidzialna. Przestała być ludzkim przeznaczeniem i zeszła do poziomu fatalnego wypadku. Wyparcie lęku przed śmiercią z codziennego życia nie przyniosło jednak ludziom spodziewanego duchowego spokoju, a miejsce lęku przed śmiercią zajął lęk przed życiem (BAUMAN 2003). Powaga śmierci implikuje w porządku kulturowym ironiczny i groteskowy dystans do niej, różne formy gry ze śmiercią, a organizowanie produktów rozrywkowych i turystycznych wykorzystujących motyw śmierci świadczą o jej stałej obecności.

Inne procesy społeczne przyczyniające się do zmiany postaw wobec śmierci to urbanizacja, atomizacja rodziny i rozwój medycyny. Zanikanie rodzin wielopokoleniowych, tym samym zanikanie naturalnego systemu opieki i oparcia dla ludzi starszych i umierających, prowadzi do ograniczenia możliwości obserwowania i przeżywania śmierci w gronie najbliższych, a umierających stawia $\mathrm{w}$ roli odrzuconych. Rozwój medycyny sztucznie podtrzymującej życie za pomocą rozwiniętych technologii doprowadził do instytucjonalizacji choroby, a szpitale stały się miejscem powolnego i anonimowego umierania. $Z$ wydarzenia rodzinnego śmierć stała się wydarzeniem szpitalnym. Elementy śmierci, które są szczególnie nieestetyczne, są usuwane $\mathrm{z}$ pola widzenia rodziny. $\mathrm{Z}$ czasem cały proces umierania $\mathrm{w}$ społeczeństwach uprzemysłowionych stał się ukryty i otoczony milczeniem, pozostawiony specjalistom. Stopień medykalizacji procesu umierania można uznać za jeden ze wskaźników otwartości, z jaką społeczeństwo traktuje śmierć i umieranie (OSTROWSKA 1991, s. 34), niestety usuwanych z doświadczeń życiowych współczesnego człowieka, co niewątpliwie wpływa na izolacje sacrum śmierci, a w konsekwencji wyeksponowanie jej wymiaru profanum. Szczególnie jest to widoczne $\mathrm{w}$ wykorzystaniu przestrzeni śmierci w turystyce, którego stopień jest uzależniony od specyfiki kulturowej zarówno turystów, jak i organizatorów przestrzeni tanatoturystyki.

Potwierdzeniem tezy o próbie izolacji śmierci w życiu współczesnych społeczności krajów rozwiniętych jest postawa wobec żałoby, kojarzonej ze smutkiem i żalem, stojącej w opozycji do szczęśliwego życia, a polegająca na ograniczeniu lub całkowitym jej wykluczeniu. Postawa taka narodziła się 
w Stanach Zjednoczonych na początku XX wieku (ARIÈs 2007, s. 99). Okres wojny secesyjnej zburzył pewien porządek i dotychczasowy rytuał śmierci. W XIX wieku pojawiła się w Stanach Zjednoczonych moda na balsamowanie ciała, a co za tym idzie rozwinął się amerykański przemysł funeralny, promujący ideologię, którą można scharakteryzować zdaniem „[...] aby sprzedać śmierć, trzeba jej nadać było miły wygląd". W ten sposób pojawily się domy pogrzebowe (ARIÈS 2007, s. 103), które proponowały kompleksową obsługę zmarłego. Przedsiębiorcy pogrzebowi stali się „lekarzami smutku” doctors of grief (MITFORD 2000). Zmiana oblicza śmierci poprzez zasłonięcie makijażem nie usuwa jej z pola widzenia, ale w odmienny sposób utrwala i kumuluje kolejne zyski, również $\mathrm{w}$ turystyce. $\mathrm{Z}$ tego względu $\mathrm{w}$ nieco zmienionej formie zachowane zostały niektóre rytuały pogrzebowe. Pożegnanie zmarłego stało się towarzyskim spotkaniem, mającym przynieść ukojenie żalu po starcie bliskiej osoby (szczególnie jest to widoczne podczas widowiskowych ceremonii pogrzebowych ikon popkultury).

Ceremoniał pogrzebowy i kondukt żałobny jest na całym świecie swego rodzaju teatralizacją odejścia człowieka ze świata żywych, widowiskiem atrakcyjnym dla osób trzecich, którymi są wielokrotnie turyści. Współcześnie w kulturze zachodniej żałoba będąca reakcją na śmierć, pogrzeb jako społeczna reakcja na śmierć i grób jako miejsce manifestacji śmierci tracą na znaczeniu. Żałoba stała się ze zwyczajowego, niezbędnego okresu żalu niepożądanym stanem, który należy jak najszybciej wymazać z pamięci. $W$ ten sposób według P. ARIÈSA (2007, s. 282) narodziło się tabu śmierci, przyjęte w kulturach przemysłowych, których nadrzędną wartością jest dążenie do szczęścia, połączone z dążeniem do zysku i szybkiego wzrostu gospodarczego. Ze względu na „zakaz” okazywania uczucia smutku, żalu czy żałoby młode pokolenia wykazują się coraz częściej brakiem umiejętności postępowania wobec bliskich zmarłego. Żyjący w smutku krewni są zmuszani przez zmieniające się normy społecznego życia do ukrywania bólu i w sposób ciągły prowadzenia życia towarzyskiego oraz oddawania się rozrywkom. W przeciwnym razie zostają wykluczeni, uznani za aspołecznych - zupełnie inaczej niż dawniej, kiedy odsunięcie od życia społecznego na czas żałoby było akceptowalnym nakazem. Konsekwencją tego jest sposób, w jaki współczesny turysta reaguje na obrzędy pogrzebowe, na które trafia podczas swych podróży kulturowych. Turysta nie znając rytuału i sposobu postępowania traktuje ceremoniał pogrzebowy jako "żywą" atrakcję turystyczną i dokonuje jej rejestracji, mogąc tym samym wzbudzić konflikt $z$ lokalną społecznością. Rysunek 2 przedstawia zmiany $\mathrm{w}$ interpretacji śmierci oraz w kształtowaniu się turystycznej konsumpcji jej popkulturowego wizerunku 
w społeczeństwach tradycyjnych, konserwatywnych (postfiguratywnych) i nowoczesnych, liberalnych (prefiguratywnych) ${ }^{6}$.

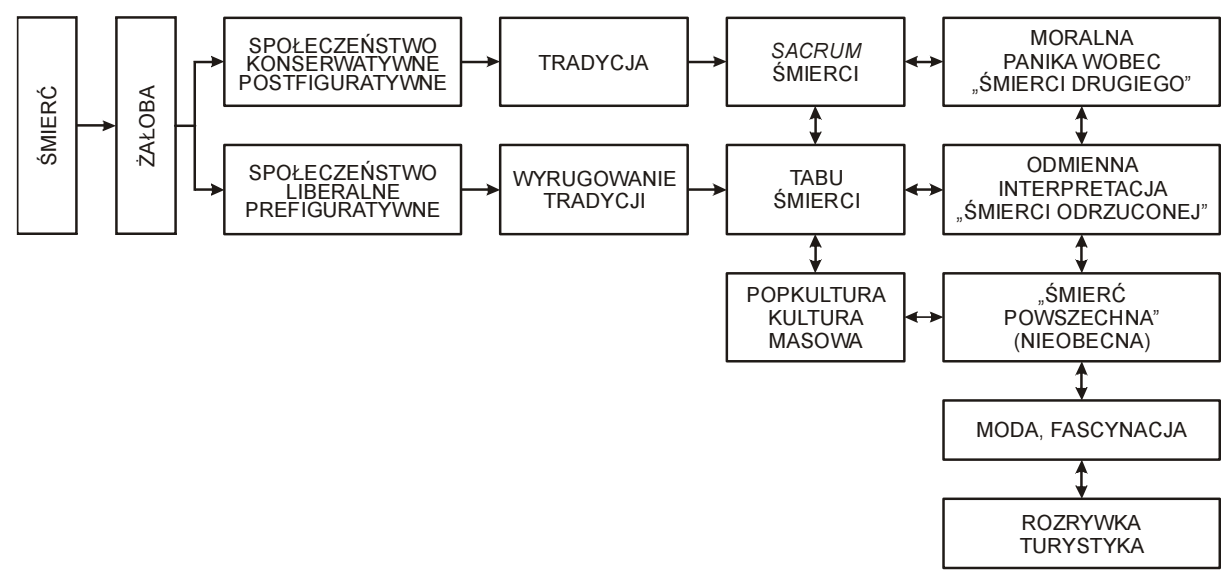

Rys. 2. Interpretacja śmierci i żałoby w społeczeństwach post- i prefiguratywnych oraz jej znaczenie w kształtowaniu popkulturowej „konsumpcji” kultury śmierci w turystyce Źródło: opracowanie własne

Społeczeństwa konserwatywne traktują śmierć przede wszystkim jako sacrum, opłakując zmarłych członków rodziny lub nieznanych im członków społeczności. „Śmierć drugiego" wzbudza strach, również z powodu obecności śmierci w życiu religijnym. Społeczeństwa liberalne, które wyrugowały ze świadomości i życia społecznego tradycyjne postawy wobec śmierci i żałoby, nie myślą o tym. Śmierć jest przeszkodą w doczesnym, wygodnym, konsumpcyjnym życiu. Dlatego nie myśli się o śmierci, nie rozmawia się o niej, uważając ją za temat tabu. Konsekwencją tego jest nieobecność śmierci w życiu człowieka, w jego najbliższym otoczeniu - śmierć dotyka innych, nie nas; jest to „śmierć odrzucona”. Jednocześnie śmierć jest powszechna w życiu, lecz ma wymiar wirtualny, abstrakcyjny, popkulturowy. Jest obecna w sztuce, filmie, mediach, Internecie, dociera do człowieka za pomocą masowych mediów. Sytuacja taka doprowadza do poczucia stanu „śmierci pow-

6 Pojęcia "postfiguratywność”, „kofiguratywność” i „prefiguratywność” zostały opisane $\mathrm{w}$ rozdziale 4.1.2. Są to terminy opisujące studium dystansu międzypokoleniowego. M. MEAD (1978), która wyróżniła kulturę postfiguratywną (kulturę odchodzących przodków, kształtujących młode pokolenie według tradycyjnego modelu), kofiguratywną (kulturę rówieśników kształtowaną zarówno przez pokolenie starsze, jak i młodsze, wspólnie tworzących normy kulturowe) i prefiguratywną (kulturę kształtującego się młodego pokolenia odrzucającego tradycyjny model życia, tworzącego nowe normy kulturowe), z łac. figuratio - kształtowanie, post późniejszy, po, co - z , prae - uprzedni, przed. 
szechnej", ale nieobecnej. To z kolei rodzi wielokrotnie potrzebę rozrywki, fascynację śmiercią wirtualną, a zaspokojenie tych potrzeb jest realizowane w najrozmaitszy sposób, również poprzez podróże tanatoturystyczne.

\subsection{DZIEDZICTWO KULTUROWE ŚMIERCI}

W celu wyjaśnienia fenomenu tanatoturystyki należy dokonać próby analizy przedmiotu zainteresowania turystycznego, jakim jest kultura śmierci. W tym celu autor dokonał krótkiego przeglądu wytworów kulturowych powiązanych ze śmiercią wpływających na zainteresowanie kulturą śmierci przez człowieka podróżującego.

Termin „kultura” obecny był już w starożytnej łacinie i dotyczył upraw. W czasach nowożytnych pojęcie kultury pojawiło się ponownie w XVI wieku (GOLKA 2008, s. 33) w języku angielskim, gdzie kultura rozumiana była jako wysiłek zmierzający do rozwinięcia jakości jakiegoś przedmiotu (BAGBY 1975, s. 117). W XX wieku tworzono liczne definicje kultury. A. KŁOSKOWSKA (2005) definiuje kulturę jako względnie zintegrowaną całość obejmującą zachowania ludzi, przebiegające według wspólnych dla zbiorowości społecznej wzorów wykształconych i przyswojonych $\mathrm{w}$ toku interakcji oraz zawierającą wytwory tych zachowań. Definicja słownikowa kultury (BAŃKO, red. 2003) (łac. cultura = uprawa, kształcenie) obejmuje całokształt materialnego i duchowego dorobku ludzkości, wytworzonego w ogólnym rozwoju historycznym lub w jego określonej epoce; poziom rozwoju społeczeństw, grup, jednostek $\mathrm{w}$ danej epoce historycznej. Oczywiście należy pamiętać, że pojęcie i definicje kultury ewoluowały i podlegały kształtowaniu bardzo długo. Kultury nie można rozpatrywać tylko w sferze przedmiotowej (wytworów działań ludzkich), ale również w sferze treści i wzorów wartości, idei i innych symbolicznie znaczących systemów, będących czynnikami kształtującymi ludzkie zachowania (REMBOWSKA 2002b, s. 10).

Kultura rozumiana sensu largo obejmuje dziedziny ludzkiego życia, sensu stricto to strefa symbolicznego komunikowania się, zachowania i ich wytwory, ale tylko takie, których podstawowym aspektem jest obecność intersubiektywnie rozumianych znaczeń mających społeczną wartość i akceptację (np. sztuka, religia, obyczaje itp.). Istotnym elementem kultury jest komunikacja, która przebiega w "sieci związków społecznych", tym samym można stwierdzić, że taka kultura, jakie komunikowanie społeczne i na odwrót (GoLKA 2008, s. 38-44). Komunikowanie wykorzystuje znak, który jest nadawany i odbierany. Każdy znak cechuje symboliczność, umowność i intencjonalność. Śmierć jest właśnie w ten sposób odbierana - symbolicznie, umow- 
nie i intencjonalnie. Kulturę jako system symboliczny określają jej semiotyczne kryteria, co oznacza, że zjawiska kulturowe są określane za pomocą znaków. Jeżeli tak, to śmierć w ujęciu kulturowym będzie również identyfikowana za pomocą określonych znaków nadających jej semiotyczny charakter (rys. 3).

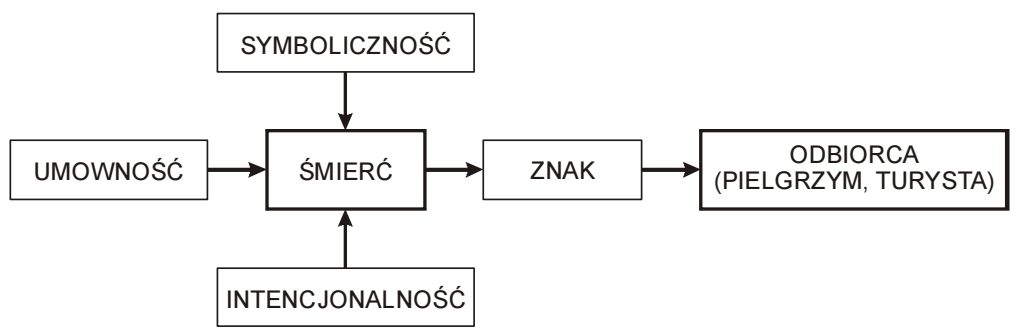

Rys. 3. Śmierć w systemie komunikacji społecznej z wykorzystaniem znaku Źródło: opracowanie własne

A. GIDDENS (2010), definiując kulturę w ujęciu socjologicznym, zwraca uwagę na jej wyuczony a nie dziedziczony aspekt. Są to wspólne wszystkim członkom społeczeństwa elementy kultury, dzięki którym mogą oni współpracować i porozumiewać się ze sobą. Zwraca uwagę na zmiany w czasie i przestrzeni wartości - będących drogowskazem w interakcjach ze światem społecznym, i norm kulturowych - stanowiących reguły zachowań, które odzwierciedlają wartości danej kultury.

Kultura jest pojęciem wieloznacznym, kształtującym się bardzo długo. W obrębie całości kultury teoria antropologiczna wyróżnia kilka jej aspektów (REMBOWSKA 2002b, s. 11):

- internalizację kultury, tj. przyswajanie jej wzorów i modeli normatywnych lub wartości przez świadomość, doświadczenie lub nawyki ludzi (np. poprzez dyfuzję kultur);

- normy, reguły i wartości kulturowe, które można oddzielić od ludzkich działań, zwłaszcza gdy są utrwalone za pomocą form symbolicznego wyrazu;

- przedmioty i wytwory, czyli artefakty;

- instytucje stanowiące zespolenie trzech pozostałych aspektów.

Globalne, antropologiczne pojęcie kultury obejmuje różnorodne postacie zjawisk: przedmioty stanowiące wytwory ludzkie, postawy, dyspozycje, nawyki będące rezultatem wcześniejszych oddziaływań i warunkiem przyszłych działań. Zjawiska te odnoszą się do człowieka jako uczestnika systemu społecznego (KŁOSKOWSKA 2005). 
Kultura w teoriach społecznych jest często determinowana geograficznie. R. FIRTH (1965) zwracał uwagę na fakt, że przyroda wytycza granice możliwości człowieka, decyduje o kulturze materialnej oraz wpływa na treść i formę wydarzeń, mitów, obyczajów. Z tego wynika, że kulturowy obraz śmierci i sposobów postępowania $\mathrm{z}$ nią $\mathrm{w}$ teoriach deterministycznych uzależniony jest również od czynników przyrodniczych i geograficznych, m.in. sposób postępowania z ciałem zmarłego i forma pochówku uzależnione są od strefy klimatycznej. Tezy o ontologicznych związkach kultury z naturą są popularne we współczesnych teoriach naukowych. Koncepcja A. KROEBERA (1973) zakłada np. wyłanianie się zjawisk kulturowych ze społecznych, a tych z kolei ze zjawisk naturalnych. Potwierdzał to również C. SAUER (1986) w swych geograficznych badaniach nad kulturami oraz inni przedstawiciele amerykańskiej szkoły geografii kultury.

Zmiany kulturowe odmiennie traktowane są $w$ teoriach ewolucjonistycznych, w których kultury są fazami rozwojowymi ogólnego procesu ewolucji kultury jako całości oraz w teoriach dyfuzjonistycznych, które cechuje zainteresowanie procesami wędrówki elementów kultury oderwanych od macierzy (REMBOWSKA 2002b, s. 15). Funkcjonaliści z kolei poszukiwali dowodów związku organicznego całości kulturowych, czyli zdolności kultury do zaspokojenia pierwotnych, organicznych potrzeb oraz potrzeb wtórnych wytwarzanych przez samą kulturę. Przestrzenny aspekt zjawisk kulturowych miał swoje początki w szkole F. Le Playa i E. Durkheima. Badania geograficzne zjawisk przestrzennych stały się podstawą dyfuzjonizmu, będących w opinii autora ważną koncepcją wyjaśniającą współczesne zainteresowanie śmiercią $\mathrm{w}$ ramach geografii kultury i geografii turyzmu.

W ramach kategoryzacji kultury można ją podzielić na kulturę materialną, społeczną i niematerialną (DOBROWOLSKI 1966). Kultura materialna obejmuje ogół wytworów fizycznych. Kultura niematerialna (zwana również kulturą duchową) dotyczy tworów niefizycznych, kultura społeczna jest natomiast kategorią określającą zachowania społeczne, na które składa się również kultura symboliczna (znaki i wartości) obejmująca działania, przedmioty oraz akty wewnętrznego, intersubiektywnego doświadczenia (REMBOWSKA 2002b).

\subsubsection{KULTURA ŚMIERCI}

Każda kultura ma sposoby radzenia sobie ze śmiercią. Są to rytuały, oczekiwania, etykiety. Z perspektywy poznawczej rytuał (walor turystyczny) może zostać uznany z różnych względów za atrakcyjny (atrakcja turystyczna), który może sprzyjać poznaniu odmienności kulturowej, tym samym 
prowadzić do budowania zrozumienia i tolerancji (lub ich braku) wobec kultury (fot. 2).

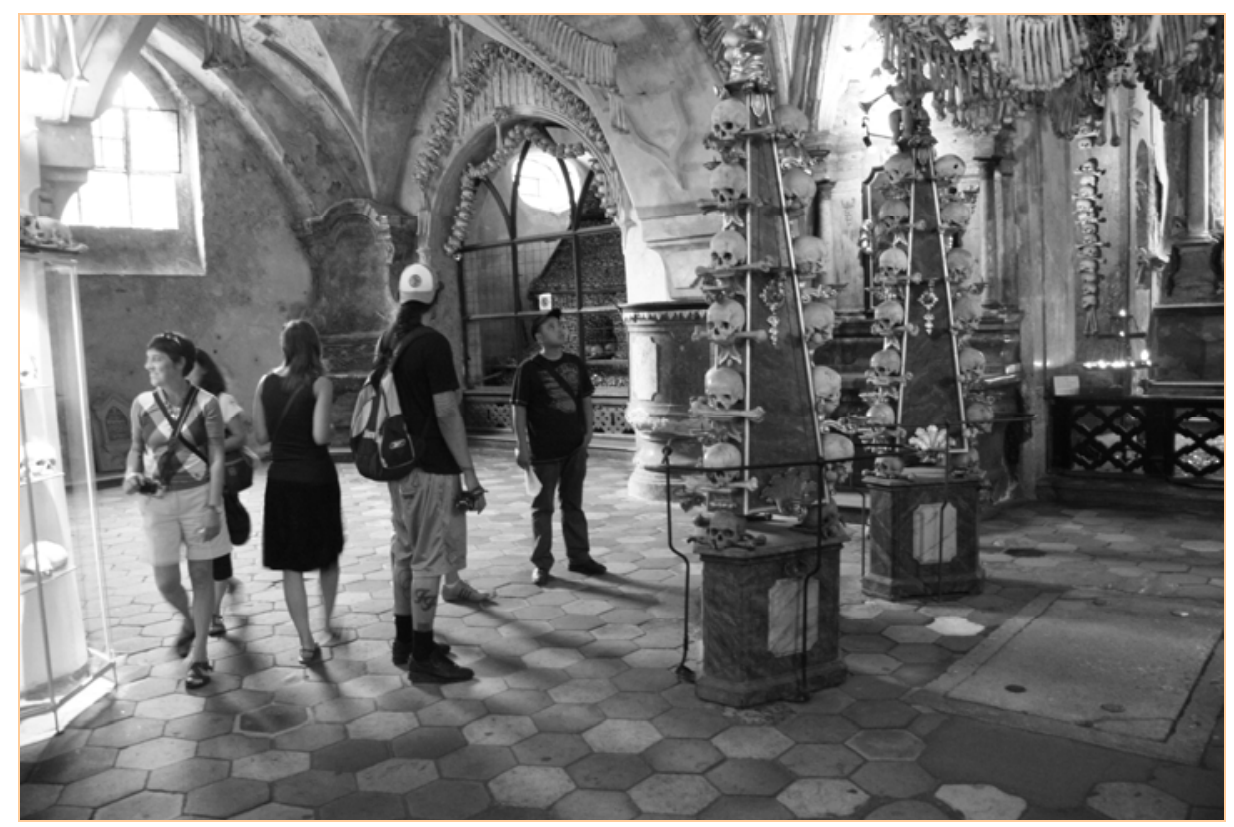

Fot. 2. Turyści w kościele cmentarnym pw. Wszystkich Świętych w Kutnej Horze - Czechy (fot. S. Tanaś)

Śmierć jest zjawiskiem trudnym do dokładnego sprecyzowania w aspekcie kulturowym. W literaturze światowej funkcjonuje od dawna pojęcie „kultura śmierci” (culture of death). Jednak najczęściej spotkamy prace wywodzące się z kręgów medycyny i etyki (SMITH 2002) oraz historii sztuki, jak np. N. LLEWELLYNA (1991), autora znanej w świecie książki pt. The Art of Death: Visual Culture in the English Death ritual c. 1500 - c. 1800. Prace interdyscyplinarne obejmują kulturę śmierci w ujęciu historycznym, artystycznym, etycznym, socjologicznym i geograficznym (JUPP, GITTINGS, red. 1999, DERRIDA 1995, GARMAN 1994, COHEN-Almagor 2001, DeMARCO, WiKer 2004, SCHANTZ 2008, GERHART 2009, NOYS 2005).

Publikacje na temat kultury śmierci obejmują:

- sfere życia społecznego determinowanego śmiercią, jak Evangelium Vitae JANA PAWŁA II (1995) piszącego o kulturze śmierci jako kulturze szerokiej niesprawiedliwości, dehumanizacji, nieuzasadnionego morderstwa, zwłaszcza aborcji i eutanazji (DENNEHY 2006), w literaturze 
polskiej najczęściej spotykany jest aspekt etyczny, moralizatorski i społeczny (KACZMAREK 2009, WARZESZEK 1997, MACHINEK 2001);

- sferę wytworów materialnych obejmujących artyzm, rzeźbę, malarstwo, literaturę (np. LLEWELLYN 1991, KOLBUSZEWSKI 1996);

- sferę wytworów niematerialnych obejmujących obrzędowość, rytuał i tradycje związane ze śmiercią i pogrzebem (KOLBUSZEWSKI 1998).

Autor niniejszego opracowania uważa, że:

Jeżeli śmierć będziemy rozumieć jako akt zakończenia życia, kresu życia, identyfikowanego przez system znaków (symboli) i przedmioty (artefakty) kształtowane w procesie ewolucji i dyfuzji kultur, to kulture śmierci możemy rozpatrywać jako ogół wytworów człowieka zarówno materialnych, jak i niematerialnych obejmujących identyfikację śmierci oraz działania, efektem których jest śmierć. Jednocześnie kultura śmierci będzie zróżnicowana geograficznie.

G. KAZBERUK (2012, s. 403) wytwory wanitatywnej i sepulkralnej sztuki plastycznej nazywa wytworami „kultury umierania”. Wytwory kultury śmierci można podzielić na:

- wytwory materialne - symbolika, sztuka, rzeźba, malarstwo, literatura, film, architektura, obiekty dokumentujące śmierć (muzea), obiekty upamiętniające śmierć (pomniki, tablice, miejsca), pamiątki, publikacje, obiekty rozrywkowe;

- wytwory niematerialne - tradycje, obrzędy, rytuały, muzyka;

- zdarzenia - akty przemocy, morderstwa, wojny, akty terrorystyczne, katastrofy, wypadki;

- inne (kulinaria, ubiór).

Tabela 1 przedstawia możliwe miejsca kontaktu turysty z wytworami kultury śmierci. Turystyczne zainteresowanie śmiercią wynika najczęściej z odmienności kulturowej, mającej wpływ na zróżnicowanie percepcji śmierci przez turystę $\mathrm{w}$ aspekcie religijnym, obrzędowym ( $\mathrm{w}$ tym formy kultu i upamiętnienia zmarłego), wiary (kultura ludowa, życie pozagrobowe, duchy, sily nadprzyrodzone, fantazmaty, nieśmiertelność, reinkarnacja, legendy, kult śmierci), traktowania zwłok (sposób grzebania, kremacja, mumifikacja, kanibalizm, gromadzenie szczątków), sposobu wyrażania emocji wobec śmierci (powaga, smutek, strach, szacunek, zabawa).

Postawy wobec śmierci początkowo rozwijały się w wyizolowanych kulturach w sposób odosobniony, kreując jednak określone rytuały, podobne $\mathrm{w}$ różnych społecznościach, np. ciałopalenie. $\mathrm{Z}$ czasem $\mathrm{w}$ wyniku dywergencji kultur postępowało zróżnicowanie w pewnych obszarach obrzędowości, co stało się powodem wzajemnych zainteresowań odmiennością kulturową i naśladowaniem określonych elementów obrzędowości. W wyniku dyfuzji 
Tab. 1. Możliwe zainteresowania turysty przedmiotami z kręgu kultury śmierci

\begin{tabular}{|c|c|}
\hline $\begin{array}{c}\text { Przedmiot } \\
\text { zainteresowania } \\
\text { (atrakcja } \\
\text { turystyczna) }\end{array}$ & Przykład, opis \\
\hline Świątynia & $\begin{array}{l}\text { epitafium, tablica, płyta nagrobna, krypta, sztuka sepulkralna, } \\
\text { symbolika (rzeźba, obraz, pieśń, muzyka), inne artefakty (np. } \\
\text { chorągwie żałobne), wiara }\end{array}$ \\
\hline Cmentarz & $\begin{array}{l}\text { forma pamięci po zmarłym, symbolika śmierci, sztuka sepulkralna, } \\
\text { roślinność, krajobraz }\end{array}$ \\
\hline Kaplica grobowa & trumna, sarkofag, sztuka sepulkralna, symbolika śmierci \\
\hline Ossuarium & szczątki kostne, sztuka sepulkralna, symbolika śmierci \\
\hline Grób & $\begin{array}{l}\text { zmarły (święty, błogosławiony, znaczący), sztuka sepulkralna, } \\
\text { symbolika śmierci }\end{array}$ \\
\hline Obrzędy, wierzenia & $\begin{array}{l}\text { pogrzeb, liturgia, święta, kult, wiara, wydarzenia (inscenizacje), } \\
\text { okultyzm, spirytualizm }\end{array}$ \\
\hline Pielgrzymka & $\begin{array}{l}\text { spotkanie z siłą nadprzyrodzoną, pielgrzymka do grobu, relikwii, } \\
\text { hołd, pamięć, wiara }\end{array}$ \\
\hline $\begin{array}{l}\text { Miejsce pamięci, } \\
\text { pomnik, tablica }\end{array}$ & hołd, pamięć, historia, edukacja, inscenizacja \\
\hline $\begin{array}{l}\text { Miejsce masowej } \\
\text { śmierci }\end{array}$ & $\begin{array}{l}\text { martyrologia, zbrodnia, tragiczne zdarzenie, akt nagłej śmierci, } \\
\text { pamięć, hołd, edukacja }\end{array}$ \\
\hline Akt wojny & $\begin{array}{l}\text { eksterminacja, ludobójstwo, pole bitwy, zbrodnia wojenna, akt } \\
\text { terroru, edukacja }\end{array}$ \\
\hline Katastrofa & katastrofa naturalna, antropogeniczna, masowa śmierć, pamięć \\
\hline Zbiorowa mogiła & charakter śmierci, historia, pamięć \\
\hline $\begin{array}{l}\text { Miejsca indywidual- } \\
\text { nej śmierci }\end{array}$ & $\begin{array}{l}\text { zbrodnia, tragedia, zdarzenie, akt nagłej śmierci, symbolika śmierci, } \\
\text { pamięć, hołd }\end{array}$ \\
\hline Muzeum, wystawa & $\begin{array}{l}\text { sztuka sepulkralna, symbolika śmierci, dziedzictwo, mumia, } \\
\text { szczątki ludzkie, edukacja, widowisko, rozrywka, popkultura }\end{array}$ \\
\hline Krajobraz & $\begin{array}{l}\text { symbolika śmierci w krajobrazie przyrodniczym i } \\
\text { antropogenicznym, krajobraz kulturowy, cmentarz }\end{array}$ \\
\hline Sztuka kulinarna & potrawy, symbolika śmierci, kultura \\
\hline Handel, usługi & $\begin{array}{l}\text { dewocjonalia, pamiątki, produkty obrzędowe, materialne wytwory } \\
\text { kultury, artefakty, obsługa przewodnicka, obsługa turystyczna }\end{array}$ \\
\hline Przekaz medialny & $\mathrm{TV}$, radio, Internet, prasa, wiedza, edukacja \\
\hline $\begin{array}{l}\text { Muzyka, literatura, } \\
\text { sztuka, film }\end{array}$ & $\begin{array}{l}\text { wyobrażenia, mity, edukacja, interpretacja, kształcenie potrzeb } \\
\text { i motywów podróży, popkultura }\end{array}$ \\
\hline Ubiór & symbolika śmierci, tożsamość, kultura, popkultura \\
\hline Rozrywka & $\begin{array}{l}\text { popkulturowy wymiar śmierci, parki rozrywki, wystawy } \\
\text { tematyczne, duchy, fantazmaty, okultyzm }\end{array}$ \\
\hline
\end{tabular}

Źródło: opracowanie własne.

kultur następowało rozprzestrzenianie i przenikanie do odrębnych kultur pewnych tradycji. W ten sposób tworzyły się nowe, synkretyczne postawy wobec śmierci, odmienne od postaw pierwotnych. 
Kultura śmierci może być więc odczytywana odmiennie przez turystę świadomego, przygotowanego, którym częściej jest jednostka przygotowana do odbioru kultury wysokiej. Kultura śmierci będzie traktowana jako element dziedzictwa kulturowego, tradycji, a kontakt z artefaktami śmierci będzie miał charakter edukacyjny. Turysta nieświadomy, nieprzygotowany wcześniej do interpretacji kultury śmierci, będzie ją odbierał w kategorii nowoczesnego produktu kulturowego (turystycznego). Jego percepcja może, ale nie musi, ograniczać się do prostego, popularnego odbioru nacechowanego pierwiastkiem rozrywkowości (rys. 4).

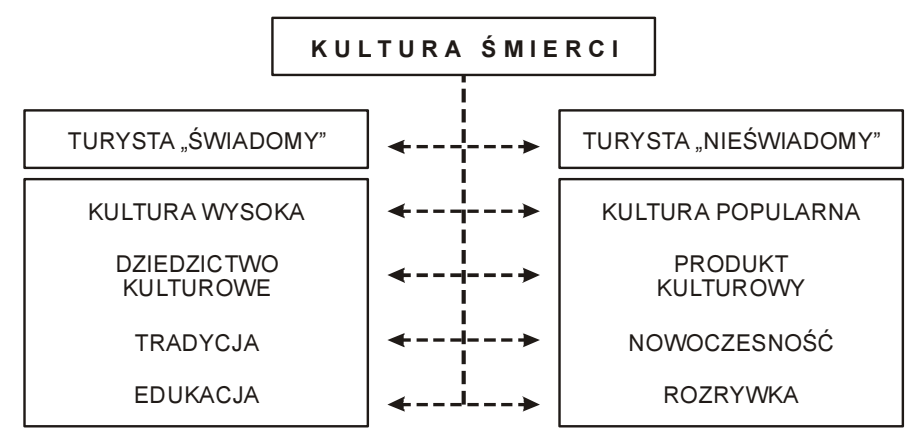

Rys. 4. Sposób percepcji kultury śmierci z perspektywy turysty „Świadomego" i ,"nieświadomego"

Źródło: opracowanie własne

Dyfuzja kulturowa, zaproponowana przez R. Lintona (1975; za: GOLKA 2008, s. 239-240), ściśle wiąże się z geograficznym zróżnicowaniem kultury śmierci. Rozprzestrzenianie się elementów kultury podlega pewnym prawidłowościom, a mianowicie:

- elementy kultury zostają przyjęte przez społeczeństwa stykające się $\mathrm{z}$ obszarami ich powstania (w Polsce nagrobki tatarskie zdobione są fotografią, przejętą z tradycji katolickiej);

- jeżeli nowy element wyparł stary, ten ostatni nadal będzie używany na peryferyjnych obszarach dyfuzji (karawan konny i orszak pogrzebowy nadal funkcjonuje na wsi, w mieście używane są karawany samochodowe, a trasa orszaku wiedzie od bramy cmentarza do grobu);

- najczęściej przemieszczają się elementy funkcjonalnie powiązane (śmierć szpitalna determinuje lokalizację domów pogrzebowych przy szpitalach);

- dyfuzja kulturowa przebiega etapowo - wpierw pojawia się nowy element i następuje zainteresowanie nim, następnie jest przyjęty i ze- 
spolony z dotychczasowymi elementami kultury (dekoracje nagrobne, sztuczne kwiaty, kondukt samochodowy);

- dyfuzja przebiega w różnym tempie (krematoria pojawiają się szybciej w miastach);

- stopień przyswajania elementów kultury jest zróżnicowany - najłatwiej przyswajalne są demonstracyjne elementy kultury (np. karawan samochodowy), trudniej wzory zachowań (konsolacja towarzysko-wspomnieniowa), najtrudniej reakcje emocjonalne (zabawa typu Halloween, formy żałoby);

- warunkiem przejęcia elementu kultury jest jego użyteczność, prestiż, zgodność z dotychczasowymi normami (opór społeczny wobec wystaw spreparowanych ciał ludzkich);

- dyfuzja może mieć charakter lokalny lub globalny, rodzić różnorodne skutki, w tym akulturację (spirytualizm, Halloween, fascynacja makabrą).

Dyfuzja kultury śmierci jest uzależniona od wielu czynników, w tym czynników społecznych, kulturowych, historycznych, politycznych i geograficznych. W Polsce kultura śmierci jest konglomeratem tradycji przedchrześcijańskiej, chrześcijańskiej (katolickiej, protestanckiej i prawosławnej) i żydowskiej, jednocześnie kultur regionu wschodnioeuropejskiego, zachodnioeuropejskiego, śródziemnomorskiego i północnoamerykańskiego.

Materialnym wyrazem kultury śmierci jest m.in. sztuka sepulkralna, któ$\mathrm{ra} \mathrm{w}$ istocie posiada istotny walor społeczny. Sztuka pomaga $\mathrm{w}$ personifikacji, identyfikacji i wyobrażeniu śmierci. Jednak jej dzieła, forma i charakter uzależnione są od instytucji tworzącej (szkoły artystycznej, artysty), instytucji obiegu (galeria, muzeum, mass media), instytucji obecności (ekspozycja) i instytucji odbioru (turysta, pielgrzym, odbiorca). Fakt ten może wyjaśniać różnice w sztuce baroku i postmodernizmu, w których śmierć jest przedstawiana $\mathrm{w}$ diametralnie inny sposób.

Istotnym elementem kultury śmierci, z którym może mieć kontakt turysta, jest rytuał pogrzebowy. Rytuał jako element określonych zachowań społecznych może wzbudzać wśród nieuświadomionych "turystów-podglądaczy" sporo emocji, które niestety mogą być konsekwencją analizowanego wcześniej tabu śmierci i niezrozumienia, np. tradycji żałoby czy ceremoniału pogrzebowego (NOLA 2006). R.W. GRYGLEWSKI (2005) zwraca uwagę na obrzędowość wobec zwłok jako przedmiot zainteresowania kulturowego, która jest zróżnicowana geograficznie i uzależniona m.in. od warunków klimatycznych, przyrodniczych i geologicznych, czego wyrazem jest:

a) inhumacja - pochówek w ziemi; charakteryzuje większość kultur, ale nie w każdych warunkach klimatycznych i geologicznych jest możliwy; 
b) kremacja - w tym kremacja rytualna, wymagająca odpowiedniego gatunku i ilości drewna; w niektórych regionach Indii pojawia się problem braku drewna do budowania stosów pogrzebowych;

c) porzucenie ciała - pozostawianie $\mathrm{w}$ jaskiniach, na drzewach, platformach na pożarcie ptakom i zwierzętom; jest konsekwencją również określonych warunków geologicznych i przyrodniczych;

d) pochówek $\mathrm{w}$ środowisku wodnym - popularna forma pochówku na obszarach nadmorskich i przyrzecznych; w Indiach nie każde zwłoki mogą być skremowane, część $\mathrm{z}$ nich składana jest $\mathrm{w}$ rzece;

e) kanibalizm - archaiczny sposób pozbycia się ciała, warunkowany wierzeniami.

Choć z perspektywy etnocentrycznej pewne praktyki mogą zostać uznane za makabryczne, to jednak stanowią one element kultury śmierci i są przedmiotem zainteresowań poznawczych, w tym turystycznych. Odmienność rytuału może być elementem determinującym zachowanie poznawcze wobec kultury śmierci.

Ze względu na charakter książki autor przywoła tylko kilka przykładów ceremoniałów pogrzebowych stanowiących współczesną atrakcję turystyczną, a będących częścią studiów geografii kultury (KNIFFEN 1976, KONG 1999, PITTE 2004).

Przykładem mogą być wyspy Indonezji, na których organizuje się drugi pogrzeb, gdy kości zmarłego pozbawione są już ciała, na Madagaskarze rytuał famadihana jest związany z ekshumacją zwłok w celu "odwrócenia kości” i dokonania powtórnego pochówku (KeRRIGAN 2009, s. 9). Północnoamerykańscy Siuksowie Lakota umieszczają ciała zmarłych na specjalnych platformach zainstalowanych na drzewach, aby kości oczyściły ptaki, podobnie postępują aborygeni, zoroastrianie i plemiona tybetańskie. Jednym z najbardziej poruszających dla przedstawicieli społeczeństw cywilizacji zachodniej rytuałów pogrzebowych, powszechnie spotykanych w programach biur turystycznych, jest tradycja plemienia Toraja żyjącego na indonezyjskiej wyspie Celebes (Sulawesi). Tam zmarli umieszczani są na całe miesiące w tymczasowych domach, tak aby ciało uległo rozkładowi. Kiedy postęp gnilny ustaje, ciało zmarłego staje się ponownie członkiem rodziny. Po określonym czasie rozkładu ciała kości zmarłego składane są w grobach w bardzo uroczysty sposób wraz z ustawieniem drewnianych figur strzegących zmarłego. Publiczny rytuał uboju zwierząt - Rambu Solo, towarzyszący wspomnianym wyżej obrzędom pogrzebowym, obserwowany i rejestrowany przez rzesze turystów $\mathrm{w}$ regionie Tana Toraja, stanowi jedynie makabryczne doświadczenie, wzbudzające kontrowersje zachodniego turysty. Podobnie w Beninie, tradycyjnie składa się ofiary ze zwierząt podczas ceremonii reli- 
gijnych. Ta wielowiekowa tradycja pochówku jest współczesną atrakcją turystyczną, a oryginalny wytwór kulturowy stanowi podstawę organizowania wycieczek turystycznych, podczas których turysta ma kontakt z rytuałem pogrzebowym.

W Europie Północnej nadal odnajdywane są zakonserwowane zwłoki, określane mianem ofiar rytuałów celtyckich, które eksponowane są w muzeach Europy, np. kobieta z Haraldskaer, człowiek z Lindow, dziewczyna z Windeby. W wielu krajach starego świata, w Ekwadorze, na obszarach kultury azteckiej, na wyspach Oceanu Indyjskiego, jak np. na Borneo, Nowej Gwinei, turyści mogą oglądać w muzeach spreparowane ludzkie głowy, będące pozostałością tradycji dekapitacji rytualnej plemion indiańskich lub praktyk kanibalizmu.

Mumie są wykorzystywane $\mathrm{w}$ licznych rytuałach wspomnieniowych. W wielu prowincjach Peru święto Ayar Mayar Killa, w Meksyku Dzień Zmarłych ma charakter synkretyczny, łącząc tradycje chrześcijańskie z prekolumbijskimi, tak jak Dzień Wszystkich Świętych i Zaduszki w Europie łączy tradycje chrześcijańskie z pogańskimi. Na cmentarzach odbywają się pikniki połączone ze spożywaniem potraw i napojów alkoholowych. W Meksyku powszechną dekoracją są trupie czaszki wykonane z cukru. Tradycją wśród Indian środkowoamerykańskich jest również puszczanie latawców, będących według tamtejszych wierzeń łącznikiem z duszą zmarłego. Tego typu zachowania są podstawą organizowania komercyjnych wycieczek na początku listopada. Tradycje te korespondują również z brytyjskim świętem Halloween (wigilia Wszystkich Świętych), rozpowszechnionym przez kulturę masową w Ameryce Pólnocnej i Wielkiej Brytanii.

Jednym z ceremoniałów pogrzebowych, wzbudzających powszechne zainteresowanie turysty z Zachodu, jest rytuał antieszti - pogrzebowej kremacji $\mathrm{w}$ tradycji hinduistycznej. Ciało umieszczane na stosie w wyznaczonym miejscu nad rzeką jest kremowane, a prochy i szczątki zwłok wrzucane do rzeki. Różnorodność kulturowa Azji Wschodniej wpływa na wielość tradycji pogrzebowych, nawet w obrębie jednej religii. Tak więc, oprócz hinduskich stosów pogrzebowych, spotkamy kremację również w tradycji buddyjskiej. Podniebne pogrzeby kontynuowane są w Tybecie. $W$ tradycji judeochrześcijańskiej i muzułmańskiej rytuał pogrzebu i grzebania zwłok jest podobny, choć różnice wyraźnie widać na cmentarzach, w sztuce sepulkralnej i obrzędowości.

Przestrzeń śmierci to przestrzeń kojarzona $\mathrm{z}$ cmentarzem, grobem, a więc $z$ przestrzenią, którą dość łatwo jest zdelimitować. $W X X$ wieku jednak narodziła się tradycja rozsypywania prochów zmarłych w miejscach dla nich znaczących. Prochy rozsypuje się w specjalnie organizowanych parkach czy ogrodach pamięci, na murawach stadionów, placach w przestrzeniach 
przyrodniczych (np. popularnym miejscem rozsypywania prochów jest góra Snowdon w Walii), czasem upamiętniając ten fakt tablicą. W ten sposób przestrzenią śmierci może okazać się otoczenie, w którym widz-turysta zupełnie by się tego nie spodziewał.

W Polsce w wiekach XVII i XVIII popularne były portrety trumienne widoczne jedynie $\mathrm{w}$ trakcie pogrzebu, a następnie umieszczane na ścianach krypt lub kościołów. Współcześnie portrety trumienne są udostępnione w kolekcjach wielu muzeów, z największą polską kolekcją w Muzeum Ziemi Międzyrzeckiej. Jednym z bardziej widowiskowych elementów polskiego rytuału pogrzebowego był katafalk, który od XVII stulecia, wraz z inscenizacją jezuicką, nabrał znaczenia "operowego" (ARIÈs 1989, s. 173). Castrum doloris było budowaną na zamówienie sceną z barokową oprawą i sepulkralną dekoracją, lokowaną w centralnym punkcie świątyni, współcześnie odtwarzane podczas organizowanych wystaw prezentujących kulturę śmierci okresu polskiego sarmatyzmu (np. w pałacu Biskupa Erazma Ciołka, oddziale Muzeum Narodowego w Krakowie).

Współcześnie rytualizacja śmierci pojawiła się również na drogach publicznych. W Polsce powszechnym jest stawianie w miejscu tragicznego zdarzenia krzyży lub małych kapliczek świadczących o czyjejś śmierci (MATYKOWSKI, DURA 2010).

Kulturowe zróżnicowanie rytuału pogrzebowego i upamiętnienia zmarłego stanowi podstawę organizowania współczesnych wycieczek turystycznych do przestrzeni śmierci, podczas których turysta ma również styczność z szeroko rozumianą geografią kultury.

\subsection{2. ŚMIERĆ A TOŻSAMOŚĆ KULTUROWA}

Każda kultura konstruuje rzeczywistość w swych przedstawieniach oraz definiuje to, czym ona jest. Określa nie tylko to, co postrzegamy poprzez przypisywanie znaczeń do doznań zmysłowych określonego rodzaju, ale również definiuje to, czego mogą doświadczyć i to, co pozostaje poza obszarem percepcji, określa więc co jest rzeczywiste, a co nie. Odczuwając bodźce nie zawsze je percypujemy, bo nie potrafimy ich zinterpretować. Nie dzielimy się doświadczeniami, bo naruszyłoby to naszą subiektywność. M. KRAJEWSKI (2005, s. 252) stwierdza wręcz, iż każda kultura tworzy obiektywny świat określonej społeczności, nie tylko na poziomie organizacji danych zmysłowych, ale poprzez ich selekcjonowanie jako możliwych i niemożliwych do doświadczenia. Każda kultura określa, które ze zmysłów dostarczają tylko doznań i wrażeń, a które również informacji o rzeczywistości. Hierarchia zmysłów pociąga za sobą uprzywilejowanie lub zmarginalizowanie do- 
świadczeń określonego rodzaju. W zależności od potrzeb i otoczenia uruchamiamy potrzebne zmysły. W przypadku przestrzeni śmierci turysta percypuje ją przede wszystkim za pomocą wzroku, słuchu i węchu. Zdarza się również, że wykorzystuje dotyk i smak.

Śmierć wzbudza niepokój i lęk, mające charakter abstrakcyjny lub biologiczny. Człowieka przeraża cierpienie fizyczne i psychiczne, przedwczesna oraz nagła śmierć. Cierpienie i nagła śmierć są tematami wielokrotnie eksponowanymi w instytucjach muzealnych. R. SCHULTZ (1978) analizował czynniki stanowiące potencjalne źródło odczuwanego niepokoju. Zaliczył do nich: cierpienie fizyczne (ból), poniżenie objawiające się w czynnościach fizjologicznych, zmiany w ciele (deformacje ciała), uzależnienie od innych, wizje przedwczesnej śmierci, konsekwencje śmierci wobec innych (pozostawienie bliskich), przerwanie realizacji ważnych zadań życiowych (wychowanie, wykształcenie dzieci, praca), nieistnienie (poczucie pustki, życie toczy się bez naszego udziału), kara za grzechy (lęk przed karą). Dramatyzm śmierci przyciąga często uwagę obserwatora, który za pomocą zmysłu wzroku i słuchu śledzi bieżące wydarzenia - wypadki uliczne, śmierć innych.

Kulturowe ideologie, wierzenia i normy definiują to, jakich emocji należy doświadczyć i jak je wyrażać. Jedna z koncepcji emocji stanowi, że nie powstają one dopóty dopóki nie dojdzie do oceny obiektów lub zdarzeń w danej sytuacji. Po dokonaniu oceny pobudzona jest emocja (ARNOLD 1960). Emocje związane ze śmiercią należą do grupy emocji pierwotnych (TURNER, STETS 2009). Są to strach, złość, smutek i wstręt oraz szczęście i zaskoczenie (tab. 2).

Tab. 2. Podział emocji według J.H. TURNERA i J.E. STETSA (2009)

\begin{tabular}{|l|l|}
\hline \multicolumn{1}{|c|}{$\begin{array}{c}\text { Emocje } \\
\text { pierwotne }\end{array}$} & \multicolumn{1}{c|}{ Emocje wtórne } \\
\hline Strach & panika, chęć ucieczki, niepokój, przerażenie, napięcie, awersja, zgroza \\
\hline Złość & wściekłość, agresja, chęć walki, chęć obrony, pogarda \\
\hline Smutek & żal, przygnębienie, samotność, rezygnacja, rozczarowanie \\
\hline Wstręt & wstyd, onieśmielenie \\
\hline Szczęście & radość, przyjemność, uciecha, zadowolenie \\
\hline Zaskoczenie & szok \\
\hline
\end{tabular}

W przypadku obiektów dokumentujących śmierć turysta niejednokrotnie odczuwa emocję współczucia, charakterystyczną dla relacji interpersonalnych. Współczucie zaczyna się od empatii, podzielonej przez C. CLARKA (1997) na poznawczą (zrozumienie natury i przyczyn stanu), fizyczną (zrozumienie stanu i odpowiedź) i emocjonalną (emocjonalna reakcja). Jednak to 
normy kulturowe określają to, co człowiek winien czuć na poziomie emocjonalnym w związku z nieszczęściem innych. Warto pamiętać, że współczucie może mieć znaczenie polityczne. Podtrzymywanie współczucia wobec śmierci, tragedii, cierpienia może być częścią szerszej strategii politycznej lub ideologicznej. Organizowanie muzeów dokumentujących śmierć i cierpienie jest tego przykładem. W Polsce dopiero po 1989 roku rozpoczęto organizację obiektów upamiętniających zbrodnie stalinowskie, akty przemocy wobec określonych grup społecznych, przy jednoczesnym braku akceptacji wobec pomysłów upamiętnienia cierpienia i śmierci w okresie II wojny światowej i w czasie przesiedleń ludności niemieckiej czy ukraińskiej, pomimo faktu zapotrzebowania na tego typu obiekty $w$ ramach turystyki sentymentalnej.

S. STRYKER (2004) twierdzi, że emocje różnicują się w wymiarze silnysłaby i pozytywny-negatywny. To oznacza, że im większe zaangażowanie $\mathrm{w}$ tożsamość $\mathrm{w}$ ramach sieci, tym większy potencjał emocjonalny reakcji, która może być pozytywna lub negatywna. Kiedy tożsamość, w którą np. turysta jest silnie zaangażowany, jest albo nie jest potwierdzana przez innych, reakcja emocjonalna będzie ostra, niezapośredniczona przez poznanie, nieświadoma. Kiedy gesty innych potwierdzą tożsamość, nastąpi pozytywne pobudzenie emocjonalne i wzrost zaangażowania turysty $\mathrm{w}$ ową tożsamość („,odczuwam smutek, strach jak wszyscy - utożsamiam się z nimi”), rośnie poczucie poprawności tożsamości, przesuwając ją w górę hierarchii. Natomiast silnie negatywna reakcja innych, w przypadku braku potwierdzenia tożsamości, zmusi turystę do ponownej oceny zaangażowania $\mathrm{w}$ tożsamość (,odczuwam smutek, strach, ale inni tego nie okazują - nie utożsamiam się z nimi"), następuje osłabienie, weryfikacja lub nie, poczucia tożsamości.

Emocje $\mathrm{w}$ procesie budowania tożsamości wynikają $\mathrm{z}$ relacji między przedstawieniami tożsamości a modelami kulturowymi. Kiedy zachowania tożsamościowe turysty będą osadzone jako adekwatne w świetle norm kulturowych określonej społeczności, skutkiem będą pozytywne emocje. I na odwrót, kiedy turysta uważa, że jego zachowania związane z tożsamością nie spełniają oczekiwań lub nie urzeczywistniają wartości narzuconych przez model kulturowy, będzie doświadczał negatywnych emocji (poczucia winy), a inni członkowie sieci mogą doświadczać złości lub rozczarowania. Tak więc, jeżeli turysta odpowiednio przygotuje się do percepcji przestrzeni turystycznej, dostosowując się do aktualnego modelu kulturowego, będzie miał poczucie tożsamości z miejscem i otoczeniem, które pozytywnie odbiera jego emocje, zachowanie. Jeżeli będzie percypował przestrzeń śmierci nieadekwatnie do modelu kulturowego, będzie czuł się wyalienowany, osamotniony (lub nieświadom oceny innych, będzie tkwił w stanie samoakceptacji), a otoczenie będzie negatywnie oceniało jego postawę. Emocje działają w ta- 
kiej sytuacji jako wyznacznik tego, czy określona tożsamość turysty jest realna i akceptowalna w odwiedzanej przestrzeni (rys. 5).

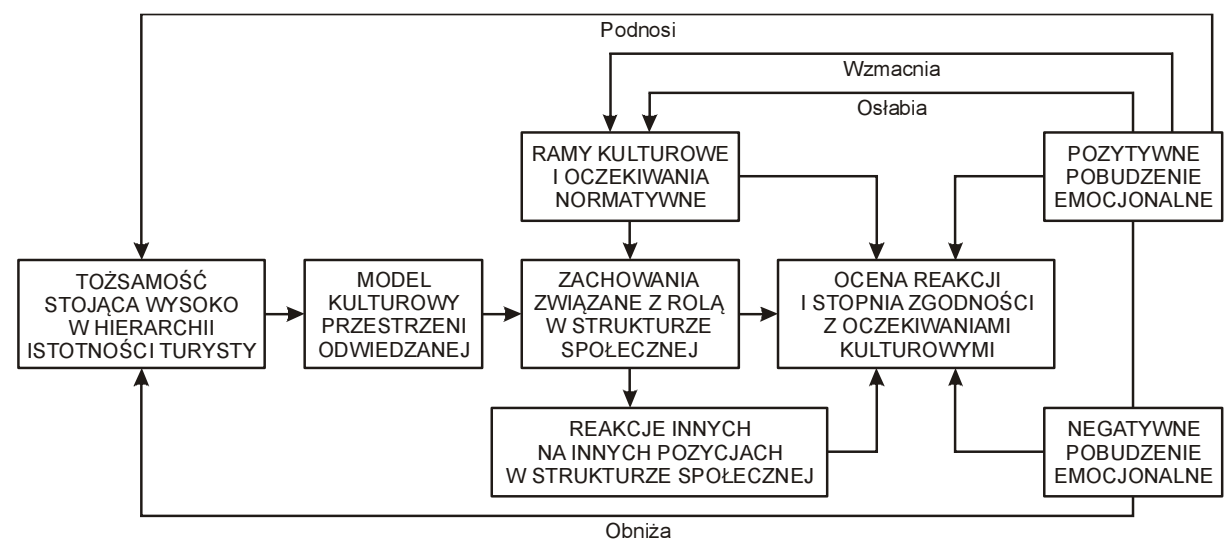

Rys. 5. Model emocji turysty kulturowego w przestrzeni śmierci Źródło: opracowanie własne na podstawie modelu emocji

S. Styrkera (2004; za: TURNER, STETS 2009, s. 135)

Kiedy zaangażowanie $\mathrm{w}$ tożsamość turysty jest silne, niepowodzenie w spełnieniu oczekiwań normatywnych będzie pobudzać silne emocje negatywne (zakłopotanie, wstyd, poczucie winy). Ponadto kiedy inni uczestnicy sieci nie spełniają oczekiwań turysty, a jest on silnie zaangażowany w jakąś tożsamość w tej sieci, to będzie okazywał negatywne afekty wobec tych, którzy nie spełnili oczekiwań. Tak więc założony model postępowania edukacyjnego $\mathrm{w}$ przestrzeni śmierci może być korzystny lub niekorzystny dla uczestników zakładanej sieci społecznej (grupy turystów, przewodników, autochtonów).

Emocje i tożsamość wpisują się również w proces kontroli społecznej. Doświadczenie $\mathrm{w}$ grupie pozytywnych emocji wskutek akceptacji reakcji innych, będą podwyższać zaangażowanie w określoną tożsamość w sieci, solidarność, to zaś umożliwi spełnienie określonych norm kulturowych. Doświadczenie negatywnych emocji będzie wymuszać dostosowanie swojego zachowania związanego z rolą, tak aby uzyskać od innych reakcje potwierdzającą zgodność tożsamości z oczekiwaniami normatywnymi. Jeśli natomiast powtarzające się próby zaprezentowania tożsamości nie powiodą się lub turysta nie jest $\mathrm{w}$ stanie spełnić oczekiwań sieci, artykułowana tożsamość będzie spadać w hierarchii, a turysta opuści sieć, jeżeli będzie to możliwe, lub zostanie od niej odsunięty; dostęp do niej zostanie ograniczony. Znakomitym potwierdzeniem zaprezentowanej koncepcji jest ograniczenie wstę- 
pu do Państwowego Muzeum Auschwitz-Birkenau w Oświęcimiu dla nienormatywnie zachowujących się turystów indywidualnych, niepodlegających takiej kontroli przez obsługę muzeum jak turysta grupowy.

Emocje są siłą napędową zaangażowania w kulturę. To one dają symbolom kulturowym znaczenie oraz kierują ludzkimi zachowaniami. W turystyce emocje odgrywają bardzo istotną rolę, ponieważ decydują o charakterze poznania. Ta sama przestrzeń, ten sam obiekt może wzbudzać u turystów skrajne emocje, w zależności od modelu kulturowego, norm kulturowych, oczekiwań i akceptacji bądź jej braku wobec przedmiotu poznania. Emocje w przypadku mrocznej turystyki opierają się na popkulturowych oczekiwaniach turysty ponowoczesnego, potrzebie otworzenia się na nowości i coraz bardziej wyrafinowane atrakcje. Tanatoturystykę należy jednak traktować bardziej w kategoriach moralizatorskiej potrzeby eschatologicznej kontemplacji (tanatopsji), choć nie można wykluczyć powierzchowności poznania kultury śmierci w aspekcie masowej i popkulturowej „pornografii śmierci”.

Emocje są regulatorem turystycznej uwagi, regulują jej rozpiętość, czujność turysty wobec otoczenia. Pozwalają uczyć się na podstawie doświadczenia i magazynować wspomnienia. Emocje pozwalają dokonywać samooceny i oceny otoczenia, przyjmować różne role, w zależności od intersubiektywności z innymi. Dzięki emocjom turysta postępuje lub nie, zgodnie z przyjętymi normami kulturowymi, emocje nadają moc nakazom i zakazom.

Aby zrozumieć fenomen rozwoju mrocznej turystyki i zmian tożsamości kulturowej w społeczeństwach cywilizacji medialnej konieczne jest odwołanie się do zmian, jakie następują w wyniku przepływu globalnej informacji. Sieciowy charakter przeplywu informacji ma znaczący wpływ na dynamikę tworzenia i treść tożsamości kulturowych (KOPROWICZ 2011, s. 122-124). Przyczyny wzrostu funkcjonalnego znaczenia komunikacji symbolicznej mają wplyw na tworzenie i rekompozycję współczesnych tożsamości turystyczno-kulturowych (rys. 6).

Różnice istoty funkcjonowania i doświadczenia symbolu przez turystę, powstające na bazie transgresyjności (przekraczania granic) form tożsamości kulturowych, są coraz bardziej oderwane od konkretnych miejsc i ludzi. Mogą być wyalienowane, oderwane od wartości osobowych turysty. Poszerzanie przez turyste granic uniwersum symbolicznego wynika z procesu deterytorializacji oraz otwierania się na przestrzenie społeczne do tej pory oddalone. Przekraczanie granic doświadczenia osobistego ma wpływ na poszerzanie granic pojmowania świata i jego relacji z sobą. Dekompozycja i rekompozycja rzeczywistości przez turystę wynika z uzyskiwania umiejętności analizy i syntezy cech odwiedzanego świata. Bez przekazu symbolicznego nie byłoby możliwe rozpoznawanie tego, co indywidualne i wspólno- 
towe. Zasoby znaczeń kulturowych są dostępne turyście praktycznie bez ograniczeń. W ten sposób może dokonać się przemiana tożsamości kulturowej turysty. Szczególnie może nastąpić w przypadku odwiedzania przestrzeni śmierci prezentujących inną, dotychczas nieznaną turyście formę rytualizacje śmierci.

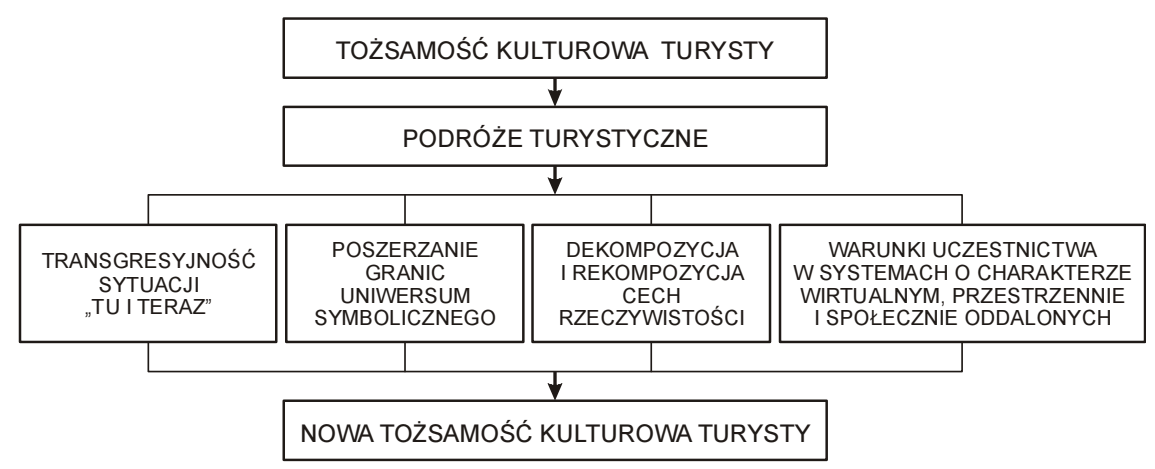

Rys. 6. Zmiany tożsamości turysty wynikające z podróży turystycznych Źródło: opracowanie własne na podstawie L. KOPROWICZA (2011)

Komunikacja symboliczna predestynowana jest do poszerzania znaczeń, ich rekonfiguracji w nowych warunkach i kontekstach. Niestety, fakt ten utrudnia komunikację międzykulturową, której różnorodność nie musi jej sprzyjać. Istotna jest głębia analizy świata znaczeń poznawanych w trakcie podróży turystycznych. Przestrzeń ma swoje znaczenie w zależności od odbiorcy i otoczenia. Te same przestrzenie śmierci w przypadku różnych odbiorców będą traktowane jako miejsca chwały lub porażki. Znaczenia będą powstawały intersubiektywnie, między podmiotami mającymi jakiś związek z określoną przestrzenią śmierci.

\subsubsection{POPKULTUROWY WYMIAR ŚMIERCI}

Jednym z kanałów dystrybucji współczesnej myśli o śmierci jest kultura masowa i popularna. Kultura masowa to treści przekazywane za pomocą środków masowego przekazu, które cechuje scentralizowanie procesu nadawania oraz rozproszenie licznych i różnorodnych odbiorców (GOLKA 2008, s. 146). Kulturę popularną można określić jako treści, które niezależnie od środków przekazu są łatwe w odbiorze, często skonwencjonalizowane oraz zawierające elementy rozrywkowe, przyciągające liczną publiczność. Kultura masowa zdefiniowana jest przez charakter przekazu, kultura popularna 
natomiast, przez cechy treści przekazu. Kultura masowa jest produktem rewolucji przemysłowej (KŁOSKOWSKA 2005), skutkiem rozwoju techniki oraz zmian społeczno-kulturowych (m.in. urbanizacji i zmian demograficznych, upadkiem kultury ludowej, przemysłowego rytmu życia, rozwoju czasu wolnego, upowszechnienia oświaty). Za rozwojem kultury masowej nastąpił rozwój turystyki masowej, opartej początkowo na walorach kultury wysokiej, a następnie kultury popularnej. Kultura masowa ma tendencje do inspiracji oraz służenia $\mathrm{w}$ kontekście politycznym i gospodarczym. Jest produktem nowoczesności, istnieje tam, gdzie docierają wpływy nowoczesności, co potęguje współczesny ruch turystyczny. Semiotyka śmierci upowszechnia się i komercjalizuje dzięki wpływom kultury masowej. Kultura masowa, a pośrednio turystyka masowa, ma dobre i złe strony. Do dobrych możemy zaliczyć m.in. demokratyzacje odbioru i upowszechnienie wytworów kultury wysokiej, edukację i dydaktykę, ekwiwalentność wobec kultury ludowej, integrację społeczną. Do negatywnych skutków zaliczymy manipulowanie opinią społeczną, bierność wobec życia, konsumpcjonizm, stępienie wrażliwości, zniekształcenie obrazu rzeczywistości, negatywny wpływ na dzieci (rys. 7).

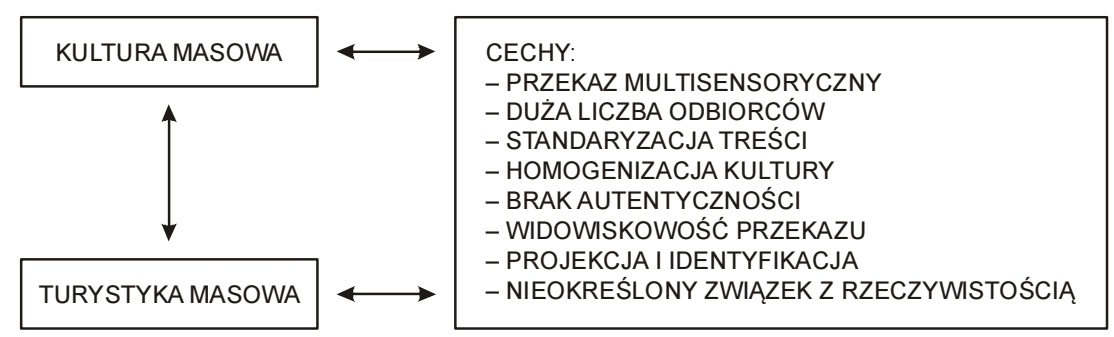

Rys. 7. Cechy kultury i turystyki masowej

Źródło: opracowanie własne według M. GOLKA (2008)

Kultura wysoka generuje stosunek do śmierci $\mathrm{w}$ aspekcie przedmiotu uznania, sacrum (elitarnego, autentycznego i wyrafinowanego interpretowania wytworów kultury). Kultura niska natomiast wygeneruje śmierć jako przedmiot profanum, rozrywki, $\mathrm{w}$ aspekcie wulgarności, trywialności i kiczowatości. Przykładem może być stosunek obserwatora do mumii ludzkich eksponowanych w rozmaitych miejscach - kościołach, kryptach, muzeach, na wystawach. W zależności od podmiotu poznającego, czy jest nim turysta, pielgrzym czy badacz, mumia będzie rodziła określone interakcje społeczne, intelektualne, estetyczne i moralne. Interakcje te będą występowały w różnych proporcjach w zależności od pozycji, jaką zajmuje mumia w odbiorze. Pozycja ta może mieć charakter obiektu kultu lub przedmiotu badań, traktowane- 
go z należytym szacunkiem i powagą lub charakter obiektu rozrywkowego, budzącego określone doznania, traktowanego z dystansem i odrazą (rys. 8).

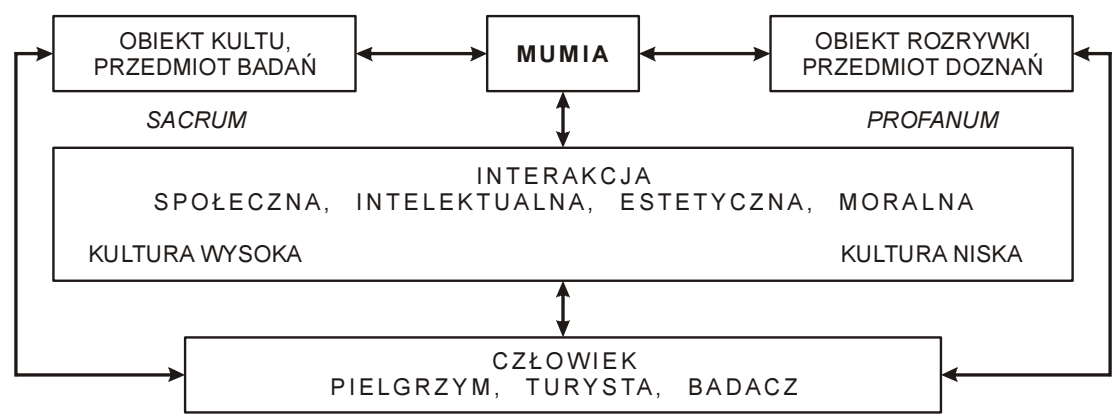

Rys. 8. Interakcja człowiek-mumia w zależności od jakości interpretacji Źródło: opracowanie własne

Kultura popularna jest często traktowana jako zagrożenie, którego ekspansję należy ograniczyć, lub jako narzędzie ideologicznego panowania (KRAJEWSKI 2005, s. 17). Kulturę popularną, zwaną również popkulturą, sprowadza się do przeciwstawiania jej kulturze elitarnej. Kultura popularna to kultura ludu, skierowana do ludu i przez lud ten praktykowana. To kultura, która zawiera wartości, przekazy, dzieła, idee odmienne (wulgarna, niska, prosta, przemijająca, ogłupiająca, skomercjalizowana), sprzeczne z tymi, które wypełniają kulturę elitarną. Kultura popularna jest również definiowana i analizowana w perspektywie jej głównego źródła, jakim jest "przemysł" kulturowy. Jest to przeniesienie zasady produkcji ekonomicznej w dziedzinę kultury, gdzie głównym kryterium wartości dzieła jest jego zdolność do generowania zysków.

Ekspansja kultury popularnej oznacza w konsekwencji zastępowanie naturalnych, rzeczywistych potrzeb ludzkich potrzebami sztucznymi. Przemysł kulturowy wytwarza substytut dzieła i substytut obywatela - biernego, pozbawionego krytycyzmu, niezdolnego do aktywności w systemie społecznym. Tak działa m.in. turystyka masowa, w ramach której obsługa turystyczna dużych liczebnie grup nie jest w stanie przekazać sensu oglądanego wytworu kultury. Poznanie w masie pozbawione jest subtelności i refleksji, jest jedynie powierzchownym zapoznaniem się ze spłyconą, uśrednioną w swym przekazie, namiastką, obrazem obiektu oglądanego. Przebywanie w przestrzeni śmierci interpretowanej jako przestrzeń poznania turystycznego jest bardzo subtelne. Grupowe odwiedzanie niweluje możliwość czasowej refleksji, zatrzymania się i kontemplacji. Turysta indywidualny ma szanse na wydłużenie czasu interpretacji i próbę zindywidualizowanego odbioru odwie- 
dzanej przestrzeni. Nie jest to oczywiście reguła, ponieważ interpretacja przestrzeni śmierci zależy w dużej mierze od przygotowania turysty do odbiory odwiedzanej przestrzeni, jego świadomości, wiedzy, światopoglądu, wieku, pochodzenia kulturowego, religijności.

Popkulturowy obraz śmierci jest dostosowany do masowego odbioru, pozbawionego tradycyjnego wymiaru sacrum, i mocno splyconego przekazu, który sprzyja tabu, niechęci wobec trudności interpretacyjnej i intelektualnej analizy odwiedzanej przestrzeni. Kultura popularna może być również traktowana jako proces, działanie podejmowane przez odbiorców wobec dzieł, przedstawień, przekazów dostarczanych przez przemysł kulturowy (turystyczny). Z pewnością jest różnica pomiędzy odwiedzinami autentycznego miejsca śmierci, jakim jest np. Państwowe Muzeum Auschwitz-Birkenau w Oświęcimiu, a sztucznego (fałszywego) miejsca prezentującego śmierć w postaci Muzeum Horroru w Wojnowicach.

Istotą tego procesu jest nadawanie znaczeń, interpretowanie, czynienie przedmiotu kultury elementem codziennych doświadczeń odbiorcy. Istota ta polegać może również na poznawczym interpretowaniu przekazu, przedmiotu w sposób niezgodny z intencjami nadawcy, a odzwierciedlający doświadczenie podporządkowanego odbiorcy. Śmierć jest codziennym elementem naszego życia, chociażby w kontakcie z medialną informacją, afirmującą i epatującą śmierć, która prezentowana jest jako widowisko mające dotrzeć do szerokich mas niewyrafinowanego odbiorcy, a nie jako obiektywna informacja o zdarzeniu (METELSKI 2001, KARAUDA 1997, KWASIK, JAROSZYŃSKI, ŁĘCICKI, red. 2012, GRALCZYK, LASKOWSKA, DRZEWIECKI, red. 2012).

Przykładem popkulturowej interpretacji przestrzeni śmierci może być turystyczna wycieczka do ossuarium. W tym przypadku ossuarium, będące miejscem gromadzącym kostne szczątki, może być odbierane przez pryzmat kultury wysokiej, jako dzieło sztuki sakralnej niosącej ze sobą przekaz eschatologiczny („pamiętaj o śmierci”, „równość wobec śmierci”), które zostanie zinterpretowane zgodnie $\mathrm{z}$ ideologią twórcy jedynie przez osoby mające wiedzę historyczną lub religijną pozwalającą na odpowiednie odczytanie tej przestrzeni. Natomiast odbiorca popkulturowy potraktuje ossuarium jako miejsce rozrywki, doświadczenia określonych emocji, a dzieło zostanie odczytane w schematyczny sposób, niekoniecznie zgodny z ideologią twórcy. W każdym z tych przykładów nastąpi jednak konsumpcja wyprodukowanego wcześniej dzieła sztuki sepulkralnej (rys. 9).

Trudno uznać, że współczesny medialny wizerunek śmierci z góry można nazwać popularnym. Nie istnieje popkulturowa śmierć jako zbiór dzieł i przekazów o określonych, specyficznych własnościach czy wartościach, ale raczej tworzą ją popularne odczytania kultury śmierci (niezgodne 
$\mathrm{z}$ tradycją). Każdy akt konsumpcji jest również aktem produkcji, ponieważ $\mathrm{w}$ jego efekcie powstaje to, co decyduje o sposobie używania dóbr dostarczanych przez producenta - znaczenia (KRAJEWSKI 2005, s. 33).

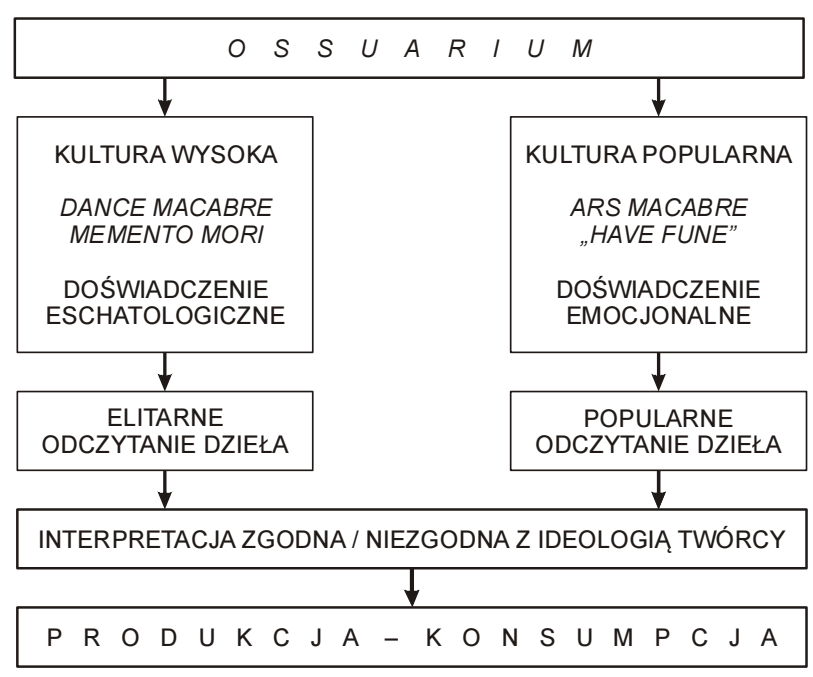

Rys. 9. Interpretacja ossuarium w kulturze wysokiej i popularnej Źródło: opracowanie własne

Warunkiem popularności jest nie tylko rozrywka i powód do zadowolenia i satysfakcji płynących z percypowania określonych przekazów lub uczestnictwa w pewnych zdarzeniach, lecz wieloznaczność i otwartość interpretacyjna przekazów. Śmierć można interpretować na różne sposoby, uzależnione jedynie od pragnień odbiorcy lub nadawcy przekazu. A więc popularność atrakcji turystycznej jest uzależniona od realizacji pragnień, potrzeb i aspiracji, i w takim kontekście należy rozumieć popkulturowy obraz śmierci w turystyce. Popularne może stać się to, czego doświadczenie opiera się na naszym osobistym wyborze, co nie jest nam narzucone z zewnątrz, do czego nie jesteśmy przymuszeni. Koniecznym warunkiem popularności pewnych zjawisk jest powszechna świadomość ich istnienia.

Popularne staje się zatem nie tyle to, co jest powszechne jako przedmiot zaspokojenia potrzeb, ale to, co powszechnie stwarza pragnienie określonego rodzaju. Warunkiem popularności jest więc świadomość istnienia pewnych przedmiotów, zjawisk (np. śmierci), które wywołują pragnienie (np. strachu), niekoniecznie ich dostępność jako narzędzia zaspokojenia tych pragnień. Zaspokojenie potrzeby emocji strachu, przerażenia, zabawy nie następuje poprzez bezpośredni kontakt ze śmiercią ( $w$ wymiarze ontologicznym), 
ale poprzez kontakt z substytutem, symbolem wystarczającym do zaspokojenia potrzeby. Dlatego popularne są obiekty prezentujące śmierć, cierpienie i makabrę pozwalające na pośredni, bezpieczny i krótkotrwały kontakt ze strachem. I to zjawisko można określić popularną kulturą śmierci, tak powszechną w wielu kulturowych produktach turystycznych. Powszechna (masowa) świadomość istnienia śmierci jest warunkiem jej popularności (rys. 10).

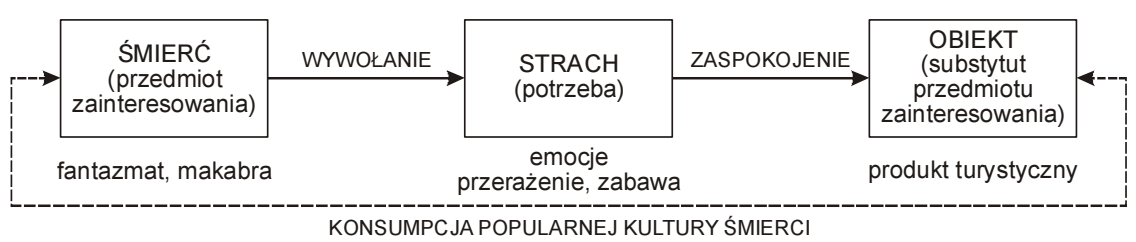

Rys. 10. Konsumpcja popularnej kultury śmierci Źródło: opracowanie własne

Opisywany fenomen popularnej kultury śmierci pojawił się właściwie tylko w społeczeństwach nowoczesnych lub ponowoczesnych, w których przełamane zostały bariery przestrzenne, a wraz z nimi świadomościowe, kluczowe dla rozwoju konsumpcji. Kultura popularna pojawiła się w przestrzeni śmierci wraz z rozwojem i ekspansją kapitalistycznego modelu produkcji. Urbanizacja wymusiła zmiany $\mathrm{w}$ środowisku życia, zmiany tożsamościowe, globalizację i unifikację norm postępowania, $\mathrm{w}$ przeciwieństwie do lokalnych, niepodlegających tak diametralnym zmianom, tradycji wiejskich. Tożsamość (GIDDENS 2001) mieszkańca miasta w wyniku konsumpcji ulega szybkim zmianom i nabiera cech indywidualnych. Na obszarach o mniejszym stopniu uprzemysłowienia nadal utrzymuje się romantyczna postawa wobec śmierci, wraz $\mathrm{z}$ kultem zmarlych i grobu. W takim przypadku popkulturowy obraz śmierci napotyka na opór.

\subsubsection{OKRUCIEŃSTWO I TRANSPARENCJA ŚMIERCI}

Jednym $\mathrm{z}$ trendów kultury popularnej jest kultura okrucieństwa i transparencji (KRAJEWSKI 2001, TAZBIR 1999). Jest to moda na prezentowanie przemocy, okrucieństwa, śmierci i zbrodni w specyficzny sposób, bo pozbawiona kontekstu moralnego oraz eliminacja kulturowych, obyczajowych, społecznych i fizycznych barier, które tradycyjnie zakreślały pole percepcji i doświadczenia. Obrazy przemocy i okrucieństwa nie są traktowane jako fragment umoralniającej opowieści, ale jako element ubarwiający rozrywkowe przedstawienie, jako warunek przyciągnięcia uwagi współczesnego widza. 
Kultura okrucieństwa nie jest środkiem dyscyplinującym i przestrzegającym przed zachowaniami aspołecznymi lub patologicznymi. Jest wykorzystywana przez producentów kultury popularnej jako czysto estetyczny i ekonomiczny sposób uatrakcyjnienia przekazu. Przemoc i okrucieństwo stały się bowiem istotnym elementem produktów kultury popularnej (KRAJEWSKI 2005, s. 127). Przez odbiorców traktowana jest jako element rozrywki.

Kultura okrucieństwa, będąca źródłem mrocznej turystyki (dark tourism) nie jest marginalna, jest paradygmatem zmian kultury popularnej. Jest potwierdzeniem, że to, co jest wykluczone i piętnowane, może stać się przedmiotem komercyjnej eksploatacji, której celem jest zadowolenie odbiorcy i udostępnienie nowego pola nieznanych doznań. Przemocą w telewizji jesteśmy najczęściej epatowani $\mathrm{w}$ filmie, programach rozrywkowych, informacjach bez przekazu umoralniającego, tylko wzbudzającego emocje. Kluczem do wyjaśnienia obecności przemocy $\mathrm{w}$ mediach jest rozumienie przemocy stosowanej wobec tych, których nic nie łączy z odbiorcą. Wynika z tego, że istotna jest identyfikacja grupowa, która wyznacza granice współczucia. Początkiem okrucieństwa wobec innych jest rozerwanie więzi emocjonalnych i degradacja człowieka postrzeganego w kategoriach przedmiotu, a nie jednego $z$ nas (KRAJEWSKI 2005, s. 162).

Przemoc i okrucieństwo $\mathrm{z}$ telewizji przeniosło się $\mathrm{w}$ świat rzeczywistych produktów - wystaw, ekspozycji, przedstawień, inscenizacji prezentujących okrucieństwa w celu wywołania określonych emocji, jednak często pozbawionych wartości informacyjnych, edukacyjnych czy też poznawczych. Producenci atrakcji turystycznych coraz częściej przekraczają dotychczas nieprzekraczalne granice moralności. Organizowanie obiektów prezentujących zbrodnie, martyrologię, śmierć i cierpienie ludzkie ma na celu wygenerować w przyszłości korzyści płynące z ruchu turystycznego. Przykładem mogą być szlaki martyrologii, muzea martyrologii czy inscenizacje pogromów i śmierci wojennej, które promowane są w katalogach turystycznych i na portalach turystycznych jako atrakcje turystyczne. Zatraca się w ten sposób istotę upamiętnienia oraz aspekt edukacyjny i moralizatorski na rzecz ekonomicznego efektu ruchu turystycznego (przykład turystycznych aspiracji organizatorów, potwierdzonych $\mathrm{w}$ prasie, inscenizacji procesu i spalenia Barbary Zdunk w Reszlu, pogromu ludności polskiej na Wołyniu w Radymnie, Muzeum Martyrologii Wsi Polskich w Michniowie czy Muzeum im. Rodziny Ulmów w Markowej). Turysta w tego typu miejscach jest więc definiowany w kategoriach ilościowych, a nie jakościowych i jest przedmiotem oddziaływania, a nie interakcji. Niestety turystyka w odróżnieniu od krajoznawstwa jest często traktowana jako narzędzie do zarabiania pieniędzy, nie zaś jako sposób edukacji. Oznacza to, że o ile okrucieństwo okaże się pro- 
duktywne jako środek kumulacji kapitału finansowego lub gwarancji zatrudnienia, to jej wykorzystanie $\mathrm{w}$ tej roli będzie się pogłębiać eliminując działanie oparte na współczuciu, empatii i odpowiedzialności. Zjawisko istnienia i ekspansji okrucieństwa i makabry w turystyce można zatem wyjaśnić poprzez efekt rynkowy, zmuszający organizatorów przestrzeni turystycznych do znajdowania nowych nisz, podatnych na penetrację turystyczną. Jednak nie jest to jedyne wytłumaczenie zjawiska. Z pewnością do motywów tworzenia takich „atrakcji turystycznych” zaliczyć można mniej lub bardziej dbałość o pamięć i próbę moralnej ekspansji wobec widza.

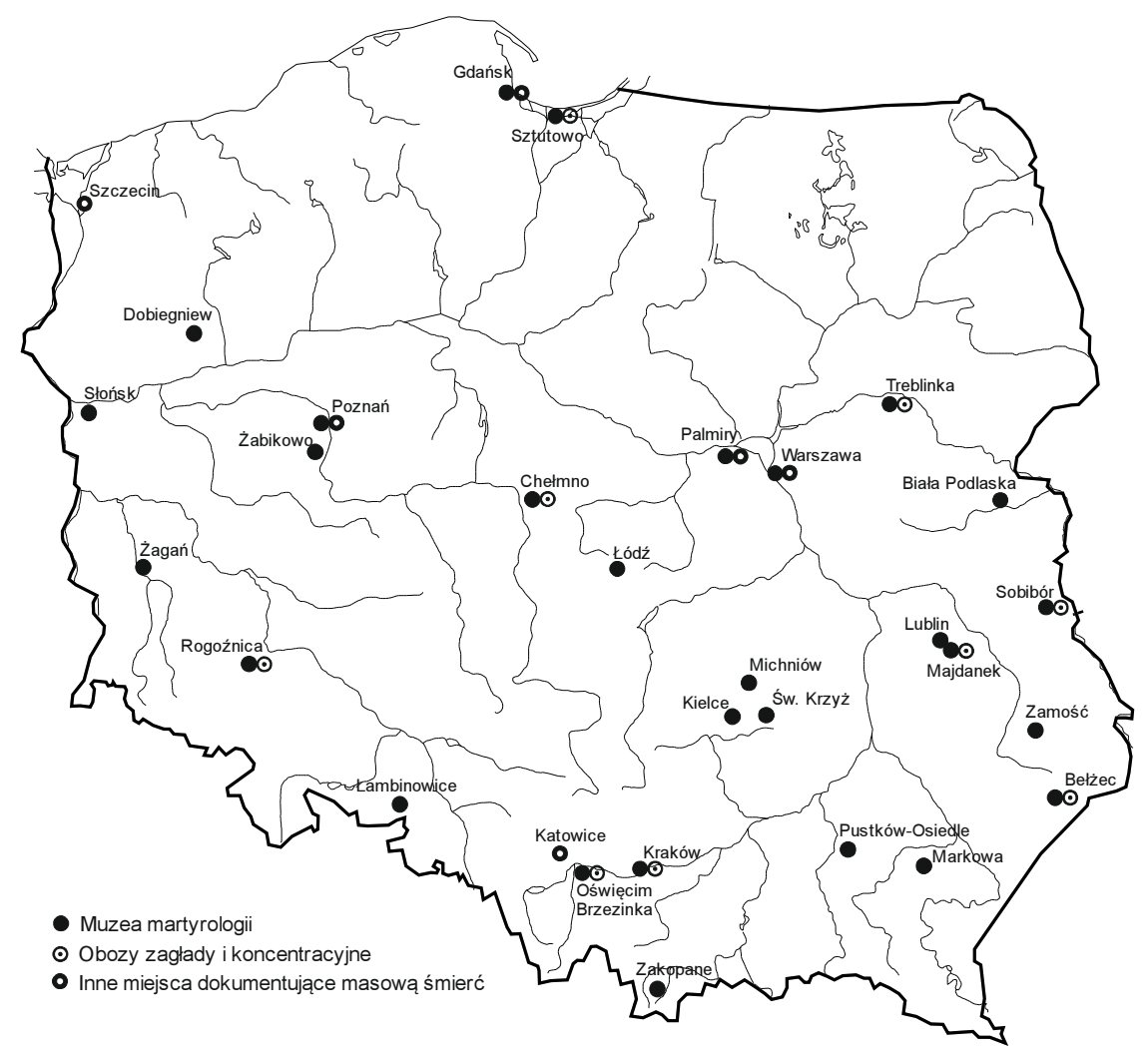

Rys. 11. Wybrane obiekty dokumentujące okrucieństwo i przemoc na obszarze Polski Źródło: opracowanie własne

Organizatorzy przestrzeni turystycznych konkurując ze sobą o turystę zmuszeni są wobec tego do tworzenia nowych atrakcji, przekraczających kolejne granice - coraz bardziej kontrowersyjnych i szokujących. Przemoc i okrucieństwo są obserwowane przez turystę zarówno w przestrzeni muzealno- 
-historycznej (pamięci), jak i w teraźniejszości. Obie perspektywy są istotne dla badań nad wykorzystaniem przestrzeni śmierci w turystyce. Turysta doznaje przemocy i okrucieństwa najczęściej poprzez wizualizację ich dramatycznych skutków w muzeach historycznych i obiektach martyrologicznych lub poprzez pośrednie lub bezpośrednie doświadczenia w trakcie turystycznych podróży (zabójstwa, akty terroru, przemoc wobec turystów) (rys. 11).

Kultura transparencji pozwala natomiast turystom uczestniczącym $\mathrm{w}$ wydarzeniach i doświadczeniach na prawach widza na kontakt $\mathrm{z}$ obszarami życia, których istnienia do niedawna nie zakładali lub były dla nich niedostępne. Kultura transparencji działa na poziomie percepcji i poznania, co sprzyja doświadczeniu i rozumieniu rzeczywistości. Przestrzeń śmierci jest jednym $z$ takich obszarów, które nie były do niedawna w kręgu szerszego zainteresowania turystów. W sposób udawany jesteśmy świadomi odkrywania tajemnic, również tajemnicy śmierci. Turysta poprzez inscenizacje, wystawy, uczestnictwo w wydarzeniach odkrywa mroczne aspekty historii, bytu życia i śmierci. Śmierć ma stać się przezroczystą sferą naszego życia, nie jak dotąd tajemną. Ujawnianie sekretów i zdradzanie tajemnic jest atrakcyjne. Przykładem na kulturę transparencji $w$ tanatoturystyce są ekspozycje szczątków ludzkich, mumii, trupów, narzędzi tortur stanowiących ukrywaną tajemnicę zamkniętych społeczności.

Kultura transparencji przełamuje rozmaite bariery ograniczające pole percepcji i poznania, ale również konstruuje ograniczenia, tam gdzie nie istnieją, tylko po to, aby je następnie przekroczyć. $W$ tym aspekcie tajemnica śmierci jest tworem kultury popularnej. Z tajemnicą związany jest lęk, który stwarza i wywołuje to, co obce i nieznane. Niewiedza i świadomość istnienia sekretów wywołują strach wynikający $\mathrm{z}$ niezdolności do kontrolowania własnego otoczenia. Dlatego kultura popularna fabrykuje tajemnice na potrzeby turystów.

Zrozumieć świat to zdolność doświadczenia tego, co z wielu powodów jest niedoświadczalne. Doświadczyć śmierci, która jest niedoświadczalna znaczy odkryć informacje, które dostępne są nielicznym. Popularność okultyzmu, spirytualizmu, kultu voodoo została rozkręcona przez kulturę transparencji odkrywającą to, co tajemnicze. Dlatego być może jedną z głównych atrakcji turystycznych Nowego Orleanu są sklepiki z akcesoriami voodoo oraz uczestnictwo w seansach spirytystycznych i wycieczkach nocnych na cmentarze.

Reasumując powyższe można stwierdzić, że kultura okrucieństwa i transparencji upowszechnia obecność przemocy i tajemnicy śmierci w obrębie kultury popularnej i przekształca je $\mathrm{w}$ bardzo atrakcyjny towar podlegający niezliczonemu pomnażaniu również w postaci produktów turystycznych. 



\section{GEOGRAFIA KULTURY ŚMIERCI}

Ujęcie geograficzne pracy odwołuje się do szeroko rozumianej antropologicznej koncepcji kultury, z wykorzystaniem dialektycznej teorii rzeczywistości społeczno-kulturowej lączącej możliwości analizy obiektywnych i subiektywnych przejawów życia społecznego (REMBOWSKA 2002b). W przypadku badania kultury istotny jest jej zdynamizowany historycznie obraz powiązany ze zróżnicowaniem geograficznym (ORŁOWSKA, red. 2002, red. 2004). Z tej perspektywy autor podjął próbę analizy społeczno-historyczno-geograficznej kultury śmierci oraz określenia powodów, dla jakich człowiek (np. turysta, pielgrzym) jest zainteresowany odwiedzeniem przestrzeni śmierci.

Kultura pozostaje w sferze badawczej geografii, ponieważ poprzez jej zrozumienie można opisać i wyjaśnić działalność człowieka, jego miejsce i rolę w przestrzeni geograficznej. P. CLAVAL (1992) zwracał uwagę na zainteresowania geografów skupiające się wokól:

- konstrukcji kulturowej miejsca, terytorium, społeczeństwa i środowiska życia człowieka;

- sposobów wyrażania odmienności kulturowej w przestrzeni;

- przyczyn zróżnicowania kulturowego na Ziemi;

- zastosowania kulturowego podejścia w geografii (ORŁOWSKA 2005).

Badania geograficzne cechuje analiza przestrzenna obserwowanych zjawisk. Szeroka ich gama, będąca przedmiotem badań geografii społeczno-ekonomicznej upoważnia do stwierdzenia, że obecną geografię - rozumianą jako dyscyplinę badawczą - można traktować w kategorii "geografii różnorodności" (KOWALCZYK 2001). Jednak A. LISOWSKI (2001) wskazuje na zagrożenia związane z eklektyzmem geografii, ponieważ - jak twierdzi: „zjawiska oryginalne i rzadkie jako przedmiot badań mogą być tylko szczegółami o walorach medialnych, a nie naukowych, pozostających w nikłym związku $\mathrm{z}$ dotychczasową wiedzą naukową".

Biorąc pod uwagę eklektyzm geografii, jak i niebezpieczeństwa, jakie mogą zrodzić się w odkrywaniu związków przyczynowo-skutkowych między dyscyplinami i subdyscyplinami naukowymi autor wyraża nadzieję, że zaprezentowane zagadnienia opisujące geografię kultury śmierci stanowić 
będą przyczynek do szerszej dyskusji nad możliwościami geograficznej analizy przestrzennych aspektów kultury śmierci, przy zastosowaniu metod wykorzystywanych m.in. w geografii społeczno-ekonomicznej.

\subsection{GEOGRAFIA KULTURY A PRZESTRZEŃ ŚMIERCI}

Geografia kultury wraz z antropologią i historią tworzą grupę dyscyplin podejmujących badania nad problemami działalności człowieka w środowisku przyrodniczym i jego przekształceniami, czego wyrazem jest dziedzictwo i krajobraz kulturowy. Geografia kultury definiowana jest jako dyscyplina badająca oddziaływanie kultury materialnej i niematerialnej na środowisko przyrodnicze oraz organizacje przestrzeni geograficznej, w tym przestrzeni życia człowieka (JACKOWSKI 2007, MARGUL 1986).

Punktem wyjścia rozważań nad koncepcją badań przestrzeni śmierci powinna być jej geograficzna interpretacja. Przestrzeń określa bowiem odrębność geografii jako nauki empirycznej. Drugim filarem badań przestrzeni śmierci powinien być czas. Geografia jako nauka chorologiczna (LISOWSKI 2003, 2005, JĘDRZEJCZYK 2008) nie może istnieć bez ontologii, a więc ogólnej teorii bytu, zarówno $\mathrm{w}$ interpretacji przestrzeni, jak i czasu. Znaczenie $\mathrm{w}$ badaniach geograficznych ma również dialektyczny związek przestrzeni i czasu. Biorąc powyższe pod uwagę $\mathrm{w}$ badaniach nad geografią śmierci, analizowaną w dalszej części książki, opierając się na koncepcjach geografii człowieka i geografii humanistycznej, istotna będzie zmienność w czasie i przestrzeni śmierci oraz następstw, jakie ona wywołuje.

Na przełomie XIX i XX wieku wykształciła się nowa dyscyplina geograficzna, nazwana przez F. Ratzla antropogeografią. Antropogeografia wywodzi się z refleksji nad miejscem i rolą człowieka w świecie, czerpiąc z koncepcji i teorii filozofii, nauk przyrodniczych i społecznych. Geografia śmierci, której podmiotem jest przede wszystkim człowiek, lecz nie jest to wymóg konieczny, wpisuje się właściwie w koncepcję antropogeografii. F. Ratzl rozumiał ją jako naukę o wpływach czynników geograficznych, utożsamianych z przyrodniczymi, na życie ludzi. Jest to zatem nauka "o wzajemnych stosunkach między Ziemią a produkującym i reprodukującym się życiem ludzkim" (JĘDRZEJCZYK 2008, s. 20). Przestrzeń geograficzna jest częścią przestrzeni rzeczywistej, a głównym obiektem wypełniającym tę przestrzeń są sami ludzie, natomiast kształt tej przestrzeni jest wynikiem relacji człowieka i środowiska przyrodniczego.

B. ZABORSKI i A. WRZOSEK (1939) umiejscowili w antropogeografii geografię człowieka, w ramach której znalazła się geografia zdrowia. Geografia 
zdrowia lub geografia medycyny zajmuje się m.in. badaniem przestrzennych aspektów śmiertelności i umieralności, co stanowi również przedmiot zainteresowania geografii śmierci. Koncepcja antropogeografii nie byłaby w stanie wyjaśnić wszystkich składowych przestrzeni śmierci obejmującej również elementy niematerialne związane $\mathrm{z}$ działalnością człowieka. $\mathrm{Z}$ tego względu geografia humanistyczna, która odeszła od przestrzeni absolutnej (TUAN 1987), a istotą której stała się m.in. ontologia fenomenologiczna, wprowadzająca obok pojęcia przestrzeni, pojęcie „miejsca”, może we właściwy sposób analizować przestrzenie śmierci. To co na początku jest przestrzenią obcą i abstrakcyjną, w miarę poznania i nadawania jej przez człowieka znaczeń staje się „miejscem”.

Geografia kultury skupiła swoje zainteresowanie m.in. na problemie dyfuzji kultur. Kultura jest w tym przypadku własnością zbiorowości określonych w czasie i przestrzeni, które różni sama kultura. Różnice między kulturami mają raczej charakter jakościowy, a nie ilościowy (REMBOWSKA 2002b, s. 47). Dyfuzjoniści uważali, że rozwój kultury odbywa się przede wszystkim poprzez powielanie z rzadka tylko tworzonych wzorów kulturowych. O dynamice kultury decyduje wobec tego głównie intensywność kontaktów międzykulturowych. Tym samym na pierwszy plan badawczy wysuwa się wędrówka elementów kultury w czasie i przestrzeni.

Przedstawiciele amerykańskiej szkoły geografii kultury C. Sauera oceniali zmiany kultury jako rzadkie i wywoływane najczęściej przez siły zewnętrzne. W badaniach amerykańskiej szkoły Sauera przeważały studia nad cechami kultury materialnej, z pominięciem niejednokrotnie jej duchowego aspektu i ontologicznego statusu. Sama koncepcja kultury została przejęta $\mathrm{z}$ antropologii. Krytyka spuścizny amerykańskiej szkoły geografii kultury wpłynęła na uwidocznienie wpływu ludzkiej percepcji, warunkowanej kulturowo, na charakter aktywności ludzi i ich wytworów materialnych (REMBOWSKA 2002b, s. 49-50).

W odniesieniu do badań geograficznych nad kulturą śmierci należy z pewnością zwrócić uwagę na koncepcje ewolucjonistyczne rozwoju kultury, ale w określonych aspektach teorie dyfuzjonistyczne mają istotne zastosowanie, ponieważ $w$ badaniach nad percepcją przestrzeni śmierci należy zwracać szczególną uwagę na wpływ innych kultur na badaną kulturę przy jednoczesnym uwzględnieniu relatywizmu kulturowego. $W$ badaniach nad przestrzenią śmierci, jako tworu ludzkiego, nie można ograniczać się jedynie do scjentystycznej tradycji geografii. W opisie i analizie przestrzeni śmierci należy odwoływać się również do humanistycznych koncepcji badania bytu ludzkiego i znaczeń wytworów ludzkich. Człowiek, wchodząc $\mathrm{w}$ interakcję ze środowiskiem, tworzy epistemologię geografii, której podsta- 
wą są indywidualne wyobrażenia, doświadczenia i fantazje. Nie zawsze jest możliwe odkrycie i opis takich indywidualnych geografii. Potrzeba uwzględdnienia przez geografów kontekstu zachowań ludzkich wobec śmierci staje się wyraźniejsza, gdy uwzględnimy środowisko symboliczne, w jakim człowiek działa.

Humanizm odrzuca częściowo pomiary agregatywne. Zamiast nich proponuje metodologię, dzięki której odkrywa się znaczenia przypisywane środowisku przez poszczególne osoby lub grupy za pomocą technik, takich jak obserwacja uczestnicząca, pomiar dyskretny i różne formy pogłębionych wywiadów (LEY, SAMUELS 1978). Niemożliwa jest wyłączna kwantyfikacja interpretacji śmierci, która jest bardzo subiektywna i zależna od wielu czynników kulturowych.

Humanistyczna koncepcja kultury w geografii została szczegółowo opisana przez K. REMBOWSKĄ (2002b), która zwraca uwagę na fakt, że człowiek żyje nie tylko $\mathrm{w}$ świecie fizycznym, ale także $\mathrm{w}$ świecie symbolicznym, którego częścią jest również kultura śmierci. Zewnętrznej, zobiektywizowanej postaci kultury, wyrażającej się w działaniach ludzkich i przedmiotach wytworzonych, towarzyszy postać kultury tkwiąca w świadomości ludzkiej (normy, wzory, wartości). Warstwa ta bywa nazywana kulturą symboliczną. Kultura śmierci jest odbierana właśnie w taki sposób, symboliczny, dlatego podlega problematyce semiotycznej.

Istotnym nurtem badawczym $\mathrm{w}$ geografii kultury w kontekście śmierci jest geografia religii (JACKOWSKI 2003, KONG 1990, 2001), zajmująca się badaniem zależności między religią a przestrzenią geograficzną oraz określeniem wpływu religii i społeczności religijnych na środowisko geograficzne (JACKOWSKI, BILSKA-WODECKA, SOŁJAN 2008). W geografii religii dominuje aspekt pielgrzymowania, $w$ tym do grobów i relikwii świętych, lub w innych celach związanych z sacrum śmierci (JACKOWSKI, SOŁJAN, BILSKA-WODECKA 1999). $\mathrm{Z}$ tej perspektywy badania nad geografią śmierci obejmują również zagadnienia religijne.

\section{2. ŚMIERĆ W GEOGRAFII PODRÓŻY KULTUROWYCH}

Istnieje obawa, że systemy naukowe pretendujące do ujmowania całości mogłyby rościć sobie prawo do posiadania wiedzy absolutnej i prowadzić do odrzucenia dziejowości, wolności i otwartości na nieokreśloną jeszcze przyszłość (SCHERER 2008, s. 13). Człowieka charakteryzuje jego relacja z rzeczywistością, a więc również relacja $\mathrm{z}$ otoczeniem poznawczym, w kontakcie z którym pozostaje podczas swoich podróży. Podróż na obszary kulturowo 
odmienne rodzi wiele konsekwencji, w tym próby interpretacji tego, co nieznane. Przestrzeń śmierci jest przedmiotem poznania geograficznego i turystycznego rodzących potrzebę zrozumienia otaczającej podróżującego rzeczywistości, również przez pryzmat jego własnej śmiertelności.

Dla stanowiska wobec śmierci niebagatelne znaczenie ma doświadczenie zdobyte $\mathrm{w}$ kontaktach $\mathrm{z}$ kulturami, religiami, sztuką, czemu sprzyja przemieszczanie się człowieka $\mathrm{w}$ przestrzeni geograficznej, przede wszystkim w celach religijnych i poznawczych. Śmierć traktowana jako kres (CHABANIS 1987, JAWORSKI 1979) jest początkiem innego bytu. Pamięć o człowieku rodzi się często wraz z jego odejściem. W tym aspekcie pamięć kreuje byt, a podróż poznawcza utrwala pamięć. W podróży (pielgrzymkowej, turystycznej) śmierć jest postrzegana przez pryzmat nadanej jej narracji (opowieści o człowieku, jego cierpieniu i śmierci) lub instytucjonalizacji, wynikającej z określonych zasad prawnych, wierzeń i obrzędów regulujących życie człowieka.

Podróż jest wielokrotnie impulsem do rozmyślania nad własną śmiertelnością i śmiercią. Doświadczenie czyjejś śmierci pobudza do refleksji nad sensem życia, cierpieniem czy śmiertelnością. Docierające do odbiorcy informacje medialne o śmierci stają się przyczynkiem do rozmyślań nad kresem życia. Być może symptomem przełamywania biernego stosunku współczesnego człowieka do śmierci jest nowa forma uczestnictwa „na odległość", poprzez medialny przekaz, w wydarzeniach mających śmiertelny skutek.

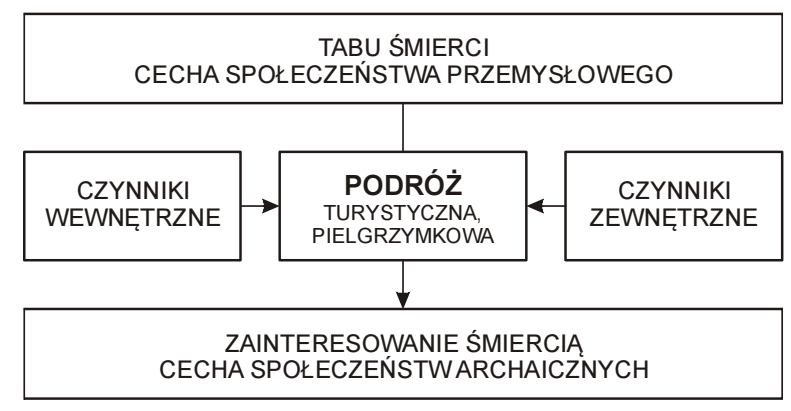

Rys. 12. Kierunek zmian w postawie człowieka wobec śmierci wywołany podróżowaniem Źródło: opracowanie własne

Rysunek 12 przedstawia kierunek zmian w postawie człowieka wobec śmierci, jakie wywołuje podróż kulturowa do przestrzeni śmierci. Zakłada on przemieszczanie się społeczeństw przemysłowych ze zróżnicowanymi potrzebami turystycznymi do społeczeństw archaicznych, o ugruntowanych tradycjach postępowania wobec śmierci i zmarłych. Ze względu na odejście 
od tradycyjnego modelu postępowania ze zmarłymi w społeczeństwach rozwiniętych ich ciekawość wzbudzają rytuały społeczeństw tradycyjnych. Stosunek do śmierci często odbierany jest przez turystów tylko w sposób emocjonalny, bez głębszej refleksji nad ich źródłem, co prowadzi jedynie do powierzchownej rejestracji rytuału. Motywy podróży, których efektem jest przejście od tabu śmierci do dyskursu o niej, determinowane są czynnikami wewnętrznymi, jak np. potrzeby, zainteresowania, osobowość podróżującego, oraz czynnikami zewnętrznymi, m.in. społeczno-kulturowymi (np. normami, moralnością) i geograficznymi (odległością, barierami fizjograficznymi).

Tak jak duchowe pielgrzymki do relikwii świętych, tak samo podróże turystyczne do przestrzeni śmierci mogą wpływać na zmianę postaw podróżującego wobec kultury śmierci, na jej interpretację i zrozumienie, a w dalszej kolejności na postawę wobec drugiego człowieka, kresu życia, wiary czy na sposób kontemplacji śmierci (tanatopsję) i postępowania w życiu codziennym.

\subsubsection{PODRÓŻE PIELGRZYMKOWE}

A. JACKOWSKI (2003, s. 120) definiuje pielgrzymkę jako podróż podjętą z motywów religijnych do miejsca uważanego za święte ze względu na szczególne działanie $\mathrm{w}$ nim Boga lub bóstwa, aby spełnić tam określone akty religijne, pobożności i pokuty. Jest to chęć obcowania z sacrum. Stownik języka polskiego (SZYMCZAK, red. 1982) definiuje pielgrzymkę jako „wędrówkę do miejsca kultu". Kult może obejmować wydarzenia, ludzi (najczęściej zmarłych), zwierzęta, rośliny, skały, przedmioty itp. W tej perspektywie należy również rozpatrywać pielgrzymki do miejsc związanych ze śmiercią męczeńską (np. za ojczyznę), śmiercią tragiczną (np. na skutek wypadku, aktu przemocy), śmiercią członka rodziny i społeczności lub inną śmiercią, która wywołała potrzebę jej upamiętnienia lub uświęcenia. Pielgrzymkę będziemy traktować wobec tego jako podróż do sacrum - miejsca świętego (JACKOWSKI 2003, s. 129), którym mogą być elementy środowiska przyrodniczego (np. święte skały, rzeki, groty) oraz obiekty stworzone przez człowieka (m.in. świątynie, mauzolea, groby, inne obiekty kultu). Celem pielgrzymek mogą być również miejsca związane z życiem, działalnością i śmiercią osób, które odegrały istotną rolę $\mathrm{w}$ kształtowaniu religii, uznanych często za świętych, jak i tych, którzy zapisali się $\mathrm{w}$ pamięci potomnych dzięki zasługom w kształtowaniu państwowości, postawom obywatelskim, zostały uznane za męczenników, oddały życie za naród, idee, poglądy.

Znaczna część podróży pielgrzymkowych odbywa się do sanktuariów (SOŁJAN 2012), które mogą być kościołami, grobami, kaplicami lub cmenta- 
rzami. Część pielgrzymek skierowana jest do miejsc świętych w celu dokonania tam żywota, złożenia zwłok w grobie, kremacji (Mekka, Medyna, Waranasi) lub odbycia innego rytuału wobec zmarłego. Są to "pielgrzymki zmarlych" (JACKOWSKI 2003, s. 134) do miejsc, które w krajobrazie są rozpoznawalne przez rozległe cmentarze lub płonące stosy pogrzebowe. Wywodzą się z wiary, że pochowanie lub kremacja zwłok zmarlego w świętym miejscu zapewnia duszy zbawienie i wejście do raju. Do dziś zjawisko to obserwowane jest przede wszystkim w islamie (Mekka, Medyna) i hinduizmie (święte miasta i rzeki - Waranasi). W chrześcijaństwie tradycja pochówku w pobliżu świętych była również znana od jego początków, jednak na masową skalę rozwinęła się $\mathrm{w}$ średniowieczu, kiedy powstawały świątynie, w których lub wokół których grzebano wiernych. Miejsca te od momentu pochowania świętego lub błogosławionego stawały się celem pielgrzymek, a odpowiednie zakony opiekowały się powstającymi sanktuariami (np. w mieście Ampurias). W literaturze zagranicznej spotkać można pojęcia "death tourism" (turystyka śmierci), "death trip" (podróż śmierci) - określających podróże do miejsca własnej śmierci, niekoniecznie naturalnej, również związanej z eutanazją (SRINIVAS 2009, MARTIN 2010, SAFYAN 2011).

Historia pielgrzymek obejmuje również podróże w celu uczestniczenia w określonych rytuałach, w tym w rytualnym składaniu ofiar.

\section{Pielgrzymki do grobów}

Pielgrzymki przez wieki były częścią życia religijnego i społecznym zjawiskiem o olbrzymim znaczeniu kulturowym. Świątynie, do których podróżowano były najczęściej grobowcami, poczynając od świętego grobu Jezusa w Jerozolimie, po relikwie w szkockim St. Andrews. Grób Świętego Jakuba Starszego w Santiago de Compostela "rywalizowal” z mogiła Thomasa Becketa, spoczywającego w angielskim Canterbury.

Od początku chrześcijaństwa najliczniejszą grupę stanowiły pielgrzymki związane z kultem grobu (męczenników i świętych). W pierwszych wiekach chrześcijaństwa do najważniejszych ośrodków związanych z kultem męczenników i świętych należały Efez, Antiochia, Edessa, Seleucja, Chalcedon, Mira, Konstantynopol, Abu Mina, Patras. Również w Europie powstało wiele tego typu ośrodków, m.in. Santiago de Compostela (grób Świętego Jakuba Starszego), Rzym (groby św. Piotra i św. Pawła), Asyż (grób św. Franciszka), Padwa (grób św. Antoniego), Canterbury (grób Tomasza Becketa), San Giovanni Rotondo (grób św. Ojca Pio). W Polsce są to m.in.: Gniezno (relikwie św. Wojciecha), Kraków (relikwie św. Stanisława Biskupa i Męczennika), Stary Sącz (grób św. Kingi), Trzebnica (grób św. Jadwigi Śląskiej), Warszawa (grób ks. Jerzego Popiełuszki), Kraków (grób św. Faustyny). 
Podróże motywowane religią odgrywają $\mathrm{w}$ wielu krajach ważną rolę i są trwałą tradycją praktyk religijnych. A. JACKOWSKI (2003) zwraca uwagę na szczególny charakter podróży religijnych, $\mathrm{w}$ tym podróży do miejsc związanych ze śmiercią, w kształtowaniu przyszłych potrzeb turystycznych. Jednym z pierwszych potwierdzeń traktowania miejsca śmierci jako waloru widowiskowego lub poznawczego kształtującego potrzebę podróży były wspomniane już groby męczenników, zwane martyrium lub memoriae, dokąd odbywały się pielgrzymki lub ostateczne podróże, celem których było złożenie ciała zmarłego w pobliżu grobu męczennika (ARIÈs 1989, s. 46). Sanktuaria poświęcone męczennikom budowano na miejscu czczonych grobów, położonych na cmentarzach extra muros. Następnie wznoszono świątynie, które były $\mathrm{z}$ czasem rozbudowywane $\mathrm{w}$ celu pomieszczenia pielgrzymów przyciąganych sławą świętego. Z czasem obecność świętych relikwii gromadziła nie tylko pielgrzymów, ale była powodem grzebania $\mathrm{w}$ ich pobliżu wiernych. Przykładem takich obiektów są odkryte bazyliki grobowe w Tipasa, Hipponie, Kartaginie, Ampurias, Saint-Sernin pod Tuluzą, Saint-Victor pod Marsylią, Tablea (ARIÈs 1989, s. 47).

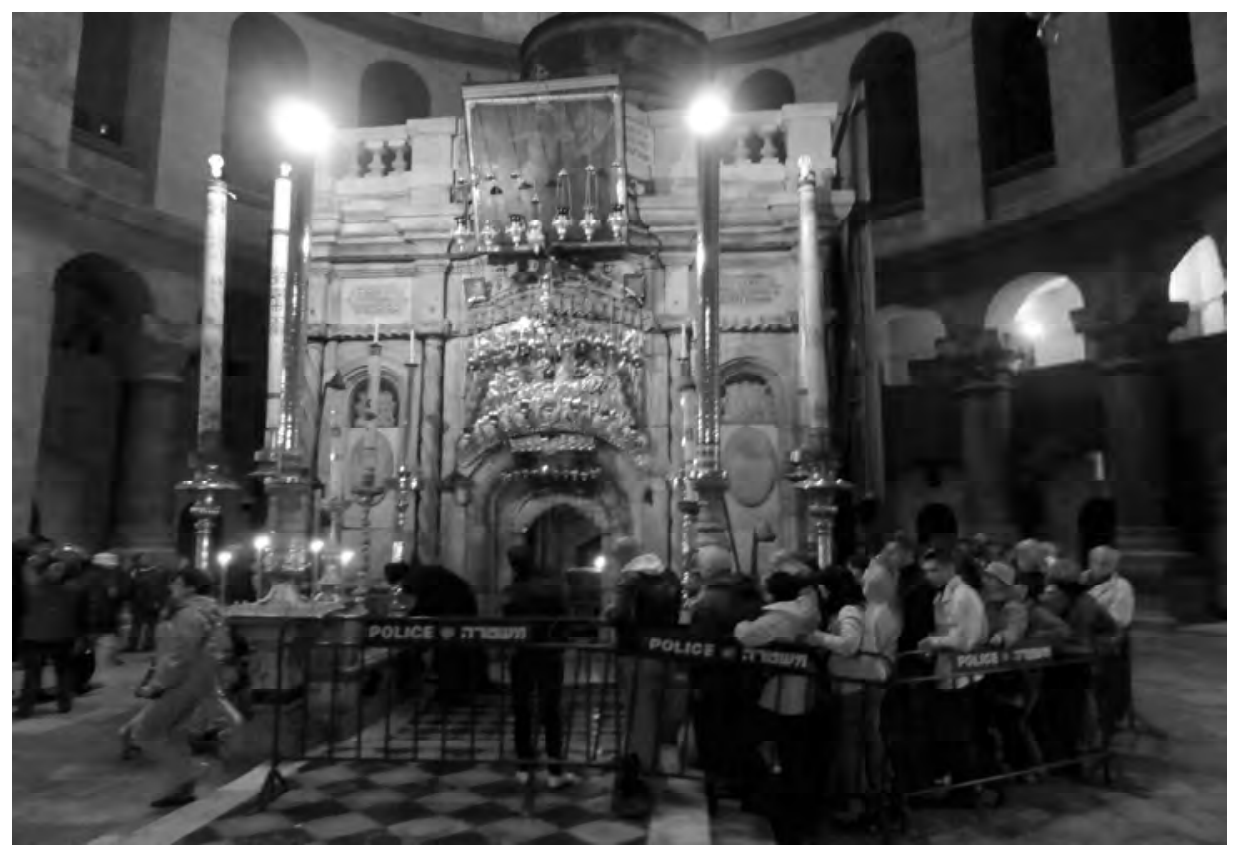

Fot. 3. Kaplica Grobu Pańskiego w Jerozolimie - Izrael (autor: S. Tanaś) 
W historii chrześcijaństwa jednym z pierwszych celów pielgrzymek związanych z kultem świętego była Jerozolima z Górą Golgotą i Grobem Pańskim. Dzięki działalności Heleny, matki Konstantego, wykształciła się moda na pielgrzymki do Ziemi Świętej, motywowana m.in. odwiedzeniem miejsca śmierci Jezusa i jego grobu, nad którym w IV wieku pobudowano bazylikę Grobu Pańskiego (fot. 3). Sanktuarium Grobu Pańskiego stało się inspiracją dla różnych obiektów sakralnych, których budowa była spowodowana sprawowaniem w niektórych ośrodkach Kościoła jerozolimskiej liturgii Wielkiego Tygodnia i wywołana rozwojem kultu relikwii Męki Pańskiej. Pielgrzymki do Grobu Pańskiego były rzadkością w VII stuleciu, po zdobyciu Palestyny przez Arabów. W związku z utrudnionymi i niebezpiecznymi podróżami do Ziemi Świętej zaczęły powstawać w X wieku w Europie obiekty sakralne z kopiami kaplicy Grobu Pańskiego (do końca XV wieku powstało około 24 kopii). Budowano również kopie samego Grobu Pańskiego (ponad 30) (JACKOWSKI 2003, s. 150). Część z nich wznieśli i pełnili przy nich symboliczną wartę Bracia Krzyżowi Jerozolimskiego Grobu Pańskiego, zwani w Polsce bożogrobcami lub miechowitami (od najstarszego klasztoru, ufundowanego w 1163 roku przez Jaksę z rodu Gryfitów).

Jednym z najstarszych i najbardziej znanych ośrodków pielgrzymowania do grobu jest Santiago de Compostela z grobem św. Jakuba. W wieku XII miejsce to zostało uznane za jeden $\mathrm{z}$ trzech najważniejszych (obok Jerozolimy i Rzymu) ośrodków dla chrześcijan. Od tej pory datują się masowe pielgrzymki z całej Europy. Do sanktuarium prowadziło wiele szlaków pielgrzymkowych, którymi wędrowali przede wszystkim pątnicy z Francji, Niemiec, Włoch, Holandii i Anglii. Na szlakach i w samym Santiago de Compostela powstawały hospicja, przy których zakładano cmentarze przeznaczone do grzebania tych, którzy zmarli w czasie pielgrzymowania do grobu św. Jakuba. Zjawisko grzebania ad sanctos, czyli najbliżej miejsca, gdzie spoczywają śmiertelne szczątki świętego, było w średniowieczu bardzo popularne. Podstawowym więc warunkiem wykształcenia się ośrodka pielgrzymkowego stało się $\mathrm{w}$ pewnym sensie posiadanie grobu świętego lub jego relikwii (JACKOWSKI 2003, s. 156), a kult jednostki i związany z tym ruch pielgrzymkowy kształtowały przestrzeń sepulkralną Europy, która współcześnie stanowi obiekt zainteresowań turystycznych (tab. 3).

Ze względu na diasporę, w jakiej żyją Żydzi, ważną rolę odgrywają ośrodki pielgrzymkowe związane z grobami wybitnych rabinów i cadyków. Najczęściej odwiedzaną przez pielgrzymów nekropolią jest cmentarz na Górze Oliwnej w Jerozolimie. Celem pielgrzymów są również Mauzoleum Patriarchów w Hebronie wraz $\mathrm{z}$ grobem Abrahama oraz groby rabinów w Meronie, Safedzie, Kathismie (JACKOWSKI 2003). W Polsce, jako światowej 
kolebce chasydyzmu, głównym miejscami pielgrzymowania są groby cadyków, zwłaszcza znajdujące się na cmentarzu Remuh w Krakowie, w Leżajsku i Dynowie.

Tab. 3. Wybrane chrześcijańskie groby świętych stanowiące cel pielgrzymów

\begin{tabular}{|l|l|}
\hline \multicolumn{1}{|c|}{ Miasto } & \multicolumn{1}{c|}{ Pochowana osoba } \\
\hline Abu Mena & Św. Menes \\
\hline Antiochia & Św. Ignacy, św. Babylas, św. Pelagia, św. Cyprian \\
\hline Asyż & Św. Franciszek, św. Klara \\
\hline Cantenbury & Św. Tomasz Becket \\
\hline Chalcedon & Św. Eufemia \\
\hline Edessa & Św. Tomasz Apostoł \\
\hline Efez & Św. Jan Apostoł i Ewangelista \\
\hline Goa & Św. Franciszek Ksawery \\
\hline Konstantynopol & Św. Jan Chrzciciel, św. Szczepan \\
\hline Mediolan & Św. Protazy, św. Gerwazy \\
\hline Myra & Św. Mikołaj \\
\hline Nevers & Św. Bernadetta \\
\hline Noli & Św. Feliks \\
\hline Padwa & Św. Antonii \\
\hline Patras & Św. Andrzej Apostoł \\
\hline Resefa & Św. Sergiusz \\
\hline Rzym & Św. Piotr, św. Paweł, św. Hipolit \\
\hline Saint Gilles & Św. Idzi \\
\hline San Giovani Rotondo & Św. Ojciec Pio \\
\hline Santiago de Compostela & Św. Jakub \\
\hline Seleucja & Św. Tekla \\
\hline Tours & Św. Marcin \\
\hline & \\
\hline
\end{tabular}

Źródło: S. TANAŚ (2008b), ze zmianami.

Wokół grobów świętych muzułmańskich zakładane były osady, które przekształcały się z czasem w miasta o funkcji religijnej. Grób Mahometa w Medynie stał się celem pielgrzymek, pomimo że sam Mahomet potępiał kult zmarłych, który stanowi współcześnie istotny element islamu. Jedna z najsłynniejszych i największych nekropolii islamskich (Dolina Pokoju Wadi-us-Salaam) znajduje się w Nedżefie w Iraku, na tyłach meczetu, w którym spoczywa Ali, kuzyn i zięć Mahometa. Niejedna nekropolia islamska rozrosła się ze względu na kult świętych, ponieważ wśród wyznawców tej religii istnieje przeświadczenie, że pochowanie zmarłego w pobliżu męczennika lub świętego daje przepustkę do raju. Wobec tego na ogół cmentarze zakładano $\mathrm{w}$ bezpośrednim sąsiedztwie grobów świętych (KOLBUSZEWSKI 1996, JACKOWSKI 2003). 
Niektóre pielgrzymki do grobów świętych muzulmańskich (ziara lub mussem) uważa się za równoważące pielgrzymkę do Mekki. Najbardziej znane ośrodki związane z kultem zmarlych, gdzie znajdują się najważniejsze islamskie nekropolie to: Medyna (Arabia Saudyjska), Meszhed (Iran), Kumm (Iran), Karbala, Bagdad i Nedżef (Irak), Kairuan (Tunezja), Mazar-i Szarif (Afganistan) (JACKOWSKI 2003) (tab. 4).

Tab. 4. Wybrane muzułmańskie groby świętych stanowiące cel pielgrzymów

\begin{tabular}{|l|l|}
\hline \multicolumn{1}{|c|}{ Miasto - kraj } & \multicolumn{1}{c|}{ Pochowana osoba } \\
\hline Adżmer - Indie & Szajch Khadja Maouddin \\
\hline Bagdad - Irak & Imam VII i IX \\
\hline Kairuan - Tunezja & Abu Zama el-Belaoui \\
\hline Karbala - Irak & al-Husajn \\
\hline Kom - Iran & Fatima \\
\hline Mazar-i Szarif - Afganistan & Domniemany grób Alego \\
\hline Medyna - Arabia Saudyjska & Mahomet \\
\hline Meszhed - Iran & Ali ar-Rid \\
\hline Mulaj Idris - Maroko & Idris I \\
\hline Nedżef - Irak & Ali Ibn abi Talib \\
\hline Samarra - Irak & Imam X i XI \\
\hline Tanta - Egipt & Ahmad Al. Badawi \\
\hline Tuba - Senegal & Ahmad Bamba \\
\hline
\end{tabular}

Źródło: S. TANAŚ (2008b), ze zmianami.

Dla wyznawców hinduizmu istotne z punktu widzenia religii miejsca kremacji zwłok, zwykle zlokalizowane nad rzekami, oraz pielgrzymki związane z pokremacyjną wędrówką prochów zmarłych. Najbardziej popularnymi ośrodkami pielgrzymek, zwanych śradha są Waranasi, Hardwar, Allahabad i Gaja. W buddyzmie celem pielgrzymek jest miejsce śmierci Buddy Kuśingara. Dla wyznawców konfucjonizmu najważniejszym ośrodkiem pielgrzymkowym jest Qufu, miejsce śmierci i grobu Konfucjusza.

\section{Pielgrzymki do relikwii}

Wierni odbywają pielgrzymki również do ośrodków, w których znajdują się relikwie z fragmentami ciała lub ze zmumifikowanymi zwłokami, eksponowane $\mathrm{w}$ relikwiarzach mających niejednokrotnie formę przeszkolonych trumien i sarkofagów. Od XIX wieku podróże te nabrały innego niż religijny charakteru. Są to podróże nacechowane motywami poznawczymi i emocjonalnymi. Turyści chcą zobaczyć ludzkie zwłoki lub ich fragmenty owiane aurą tajemniczości (fot. 4). 


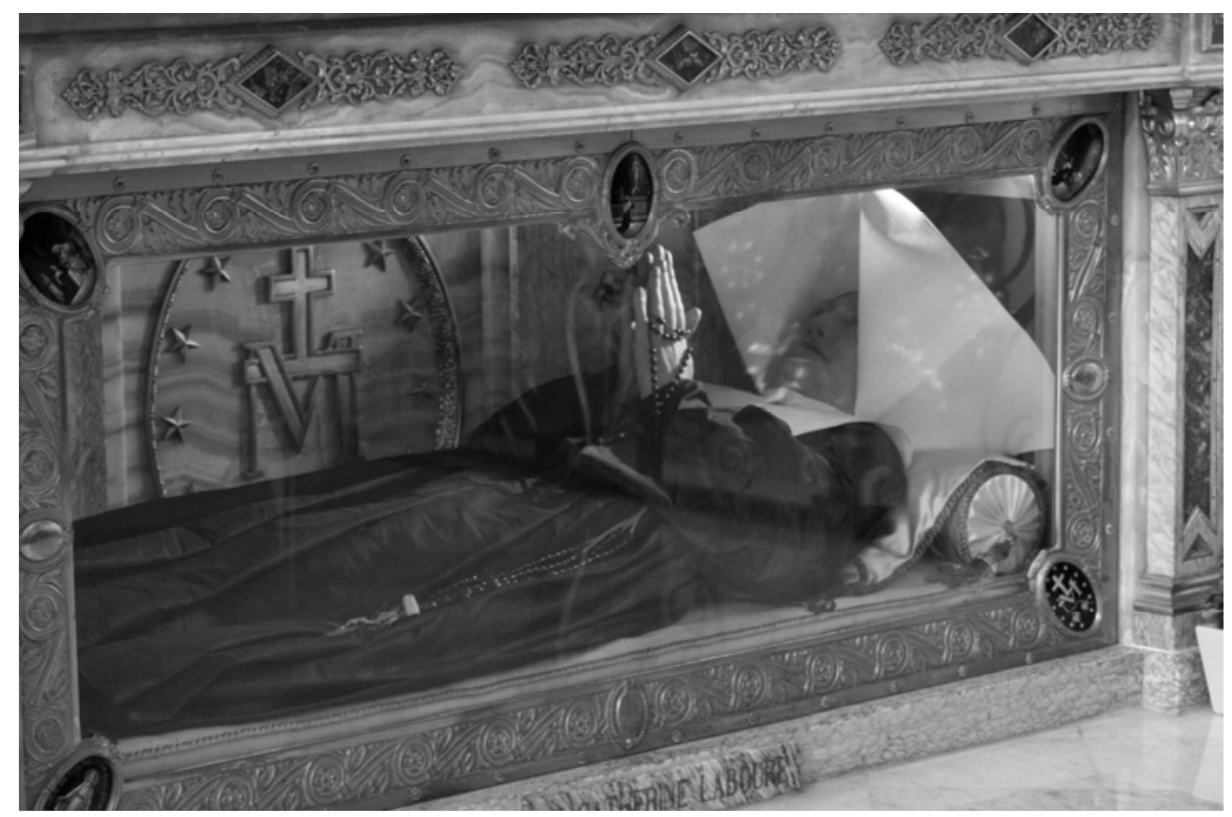

Fot. 4. Relikwie św. Katarzyny Labouré w Paryżu - Francja (autor: S. Tanaś)

Mumie pojawily się na ołtarzach kościelnych w średniowieczu, odkąd ciała świętych były ubierane $\mathrm{w}$ szaty, zamykane $\mathrm{w}$ zdobionych, szklanych trumnach i eksponowane $\mathrm{w}$ świątyniach. Jeżeli ciało uległo rozkładowi, prezentowano wiernym udekorowane szkielety albo figury z drewna lub wosku. Na całym świecie w kościołach, w szklanych trumnach-relikwiarzach wystawionych jest na widok publiczny ponad 200 zachowanych od rozkładu ciał (KWIATKOWSKI 2005, s. 20) (tab. 5).

W przypadku gdy nie można było zachować ludzkiego ciała, przeznaczano jego fragmenty na relikwie, najczęściej było to serce, ręka, głowa. $\mathrm{W}$ wielu świątyniach na całym świecie można spotkać się z relikwiarzami, szczególnie powszechnymi w Kościele prawosławnym. Również w muzeach gromadzone są relikwiarze, jak np. w londyńskim Muzeum Alberta i Wiktorii.

W kulcie ciał świętych Kościół widział istotny przejaw religijności. Do dnia dzisiejszego kult relikwii, choć znacznie mniejszy niż dawniej, nadal przyciąga pielgrzymów. Wokół relikwii organizowano życie religijne, a wiele miejscowości rozwijało się dzięki wzrostowi ruchu pielgrzymkowego (SOŁJAN 2012). Chrześcijanie wierzyli w uzdrawiającą moc świętych szczątków, co skutkowało ruchem pielgrzymkowym. Powstał nawet swego rodza- 
ju przemysł produkujący od XVII wieku woskowe manekiny, w których zatapiano fragmenty ludzkich szczątków, ubierano je w odświętne szaty i wkładano do szklanych trumien (KWIATKOWSKI 2005, s. 30). W Polsce przykład takiej figury (relikwie św. Witalisa) możemy oglądać w kościele oo. Franciszkanów przy ulicy Zakroczymskiej w Warszawie.

Tab. 5. Wybrane osoby (w Europie), których ciała są wystawione na widok publiczny

\begin{tabular}{|l|l|}
\hline \multicolumn{1}{|c|}{ Relikwie } & \multicolumn{1}{c|}{ Miejsce ekspozycji } \\
\hline Św. Alojzy Orione & Tortona - Włochy \\
\hline Bł. Alojzy Stepinac & Zagrzeb - Chorwacja \\
\hline Św. Andrzej Bobola & Warszawa - Polska \\
\hline Św. Aniela Merici & Brescia - Włochy \\
\hline Św. Bernadeta Soubirous & Nevers - Francja \\
\hline Św. Jan Bosco & Turyn - Włochy \\
\hline Św. Jan Vianney & Ars - Francja \\
\hline Bł. Jan XXIII & Watykan \\
\hline Jeremi Wiśniowiecki & Święty Krzyż - Polska \\
\hline Św. Jerzy Preca & Santa Venera - Malta \\
\hline Św. Katarzyna Labouré & Paryż - Francja \\
\hline Św. Klara & Asyż - Włochy \\
\hline Św. Małgorzata Maria Alacoque & Paray-le-Monial - Francja \\
\hline Św. Maria Goretti & Nettuno - Włochy \\
\hline Matka Elekta & Praga - Czechy \\
\hline Św. Pius X & Watykan \\
\hline Św. Ryta z Casci & Casci - Włochy \\
\hline Św. Anzelm z Lukki & Mantui - Włochy \\
\hline Św. Franciszka Rzymianka & Rzym - Włochy \\
\hline Św. Jozafat Kuncewicz & Rzym - Włochy \\
\hline Św. Magdalena Zofia Barat & Jette-Saint-Pierre - Holandia \\
\hline Św. Wincenty à Paulo & Paryż - Francja \\
\hline Św. Wincenty Pallotti & Rzym - Włochy \\
\hline Św. Wirginia Centurione Bracelli & Genua - Włochy \\
\hline Teresa Morsztynówna & Sandomierz - Polska \\
\hline & \\
\hline
\end{tabular}

Źródło: opracowanie własne.

Rysunek 13 przedstawia rozmieszczenie ośrodków pielgrzymkowych związanych z kultem grobów i relikwii świętych. 


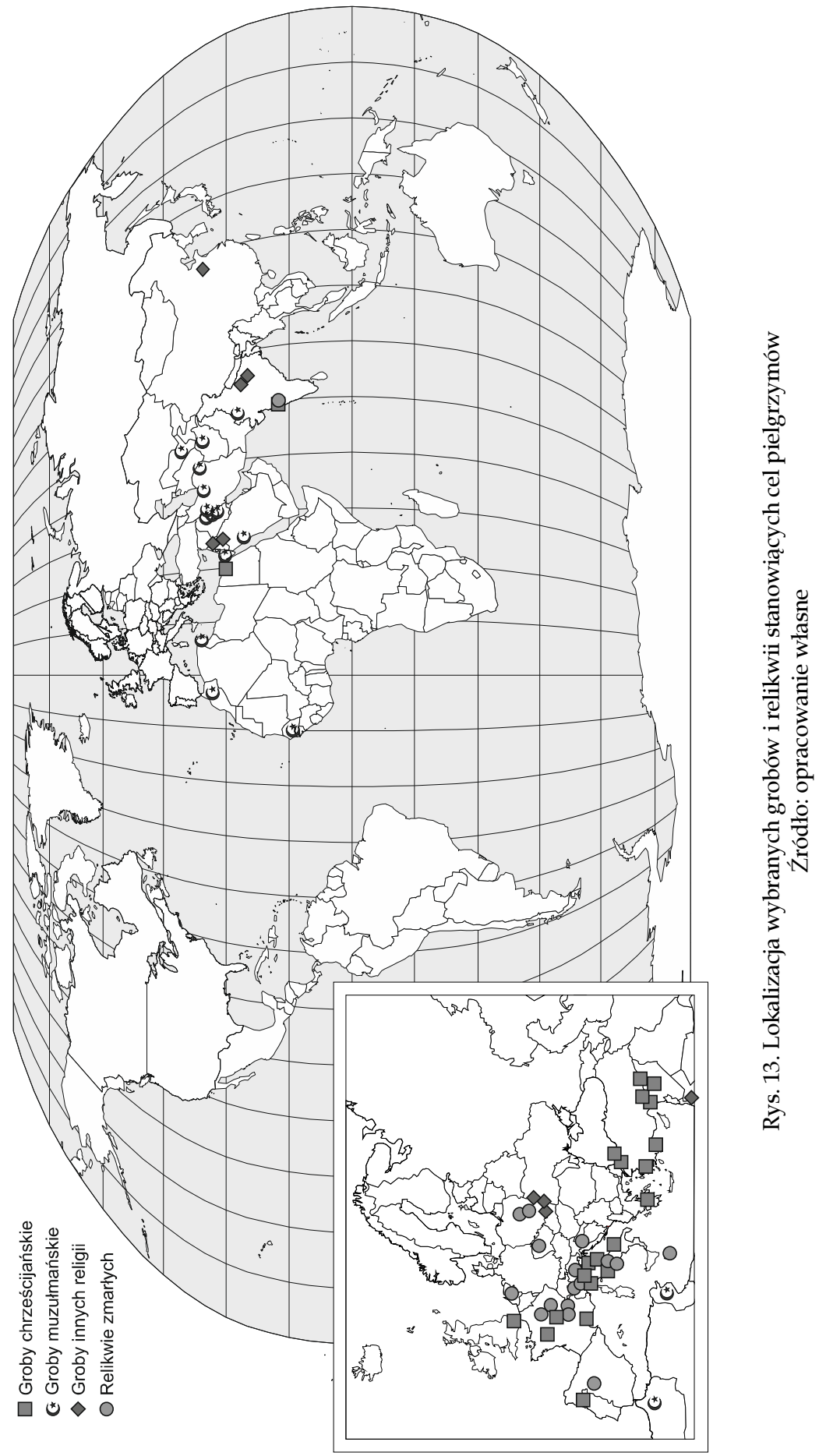




\section{Pielgrzymki do miejsc śmierci męczeńskiej}

Jak pisze A. JACKOWSKI (2003, s. 117), wielokrotnie w podświadomości pielgrzymów tkwiła również chęć poznania "mijanego" świata. Owa ciekawość inspirowała podróżników do spisywania relacji z odbywania pielgrzymek. Opisy te stały się z czasem swego rodzaju przewodnikami dla przyszłych pątników i podróżników. Pragnieniem każdego chrześcijanina była chęć dotarcia do miejsc związanych z Jezusem i jego męczeńską śmiercią. Niestety z różnych względów nie zawsze było to możliwe. Pod koniec średniowiecza w Europie Zachodniej pojawiły się więc kalwarie i drogi krzyżowe (BILSKA-WODECKA 2003). Wraz z zakładaniem kalwarii powstawały misteria Męki Pańskiej, które w okresie Wielkiego Tygodnia ściągały wielu pielgrzymów chcących uczestniczyć w inscenizacji ostatniej drogi i śmierci Chrystusa. Do najbardziej znanych stanowiących współcześnie atrakcje turystyczne należą misteria w Sewilli, Maladze i Murcii (Hiszpania), Oberammergau (Niemcy), Popayan (Kolumbia) i na wyspie Marinduque (Filipiny), a w Polsce w Kalwarii Zebrzydowskiej.

Motyw religijny współwystępował więc z motywem poznawczym i jest tak do dziś. W Polsce $\mathrm{w}$ okresie zaborów pielgrzymka stała się również elementem podróży o motywach patriotycznych, co określano mianem pątnictwa narodowego (JACKOWSKI 2003, s. 118), które odbywało się do miejsc śmierci za ojczyznę, wielokrotnie związanych z narodowym męczeństwem.

Zarówno I jak i II wojna światowa dokonały wielkiego spustoszenia wśród społeczności Europy, Azji i Ameryki Północnej. Konsekwencją tego była żałoba całych społeczeństw. Wiele państw, wobec zbiorowej traumy, stworzyło systemy wsparcia dla rodzin osób poległych, służące zachowaniu pamięci o tych, którzy odeszli. Znajdowało to wyraz zwłaszcza we wznoszeniu pomników, fundowaniu tablic, organizowaniu zbiorowych mogił i cmentarzy.

Amerykańska wojna secesyjna wpłynęła na formę upamiętnienia poległych na polu chwały. Ciała żołnierzy były grzebane na organizowanych w pobliżu miejsc bitew cmentarzach, takich jak Narodowy Cmentarz w Gettysburgu, czy w mogiłach na miejscu śmierci, jak we wraku okrętu USS Arizona w Pearl Harbour. Niestety, nie zawsze istniała szansa odwiedzin grobów poległych żołnierzy, alternatywą były zatem pomniki, memoriały z eksponowanymi nazwiskami poległych, które były budowane poza miejscem bitwy. W ten sposób moda na cenotafy, symboliczne groby, pomniki nieznanego żołnierza opanowała cały świat.

Podróże do grobów osób poległych na wojnach, w aktach terrorystycznych, podczas masowych czystek etnicznych, ludobójstwa stanowią najczęściej podróże o motywach edukacyjnych, dydaktycznych, wychowawczych, 
patriotycznych, memoratywnych. Również tego typu podróże można rozpatrywać w kategoriach pielgrzymki. Polskimi przykładami celów podróży pielgrzymkowych i turystycznych są groby pomordowanych żołnierzy w Kozielsku, Ostaszkowie i Katyniu, cmentarze wojenne poległych żołnierzy na frontach europejskich, afrykańskich, azjatyckich i amerykańskich, czy miejsce katastrofy samolotu prezydenckiego z 2010 roku w Smoleńsku.

\subsubsection{PODRÓŻE KULTUROWE}

Widowiskowość i makabra śmierci stały się motywem odbywania podróży, celem których było najczęściej bierne uczestnictwo (w roli widza) w publicznej egzekucji, choć zdarzało się, że widz brał czynny udział w spektaklu śmierci. Z tego względu można mówić o podróżach kulturowych, których powodem odbywania był i jest realny kontakt ze śmiercią. Motyw podróżowania jest uzależniony od przedmiotu i motywu poznania. $W$ przypadku podróży motywowanych potrzebą poznania kultury śmierci przedmiotem zainteresowania będą przede wszystkim forma i artefakty śmierci.

\section{Forma śmierci}

Śmierć człowieka w historii ludzkości zmieniała swoje oblicze wielokrotnie. Sposób, w jaki człowiek umierał miał również charakter widowiskowy. W tab. 6 przedstawiono zmieniający się w historii publiczny charakter śmierci, która przez wieki była ludycznym widowiskiem.

Od najdawniejszych czasów stosowanie publicznej kary, w tym kary śmierci, spełniało kilka celów. Przede wszystkim był to cel prewencyjny przed dokonaniem lub powtórzeniem zabronionego czynu, ale celem mogły być także zemsta lub odwet. Publiczna kara do końca XIX wieku miała również walor widowiska i rozrywki dla społeczności pozbawionej na co dzień możliwości uczestniczenia $\mathrm{w}$ wydarzeniach kulturalnych zarezerwowanych dla wyższych klas.

Zachodnia cywilizacja doświadczała widowiskowości kary już w okresie prehistorycznym, podczas rytualnych morderstw i całopalenia ofiar (np. Celtowie palili ofiary zamykane $\mathrm{w}$ wiklinowych konstrukcjach). W cesarstwie rzymskim śmiertelne walki gladiatorów czy pożeranie żywcem ofiar przez zwierzęta stanowily istotny element rodzącego się przemysłu rozrywkowego. Kara ukrzyżowania, stosowana m.in. przez Rzymian wobec zbrodniarzy, skupiała tłumy najczęściej poza murami miast, gdzie krzyżowano przestępców, których zwłoki wisiały tygodniami, odstraszając innych przed powtórzeniem karanego czynu. 
Tab. 6. Publiczny charakter śmierci pełniącej funkcję widowiska

\begin{tabular}{|c|c|c|c|}
\hline $\begin{array}{l}\text { Charakter } \\
\text { śmierci }\end{array}$ & $\begin{array}{c}\text { Okres } \\
\text { historyczny }\end{array}$ & Specyfika & $\begin{array}{c}\text { Region } \\
\text { (wyróżniające się } \\
\text { państwo, region) }\end{array}$ \\
\hline $\begin{array}{l}\text { Ofiary } \\
\text { rytualne }\end{array}$ & do XXw. & $\begin{array}{l}\text { Rytualne mordy, kanibalizm, } \\
\text { całopalenie }\end{array}$ & Świat \\
\hline $\begin{array}{l}\text { Walki } \\
\text { gladiatorów }\end{array}$ & $\begin{array}{l}\text { staro- } \\
\text { żytność }\end{array}$ & $\begin{array}{l}\text { Mord, okaleczanie, krwawe } \\
\text { igrzyska }\end{array}$ & $\begin{array}{l}\text { Europa, Afryka Pn., } \\
\text { Bliski Wschód, } \\
\text { (cesarstwo rzymskie) }\end{array}$ \\
\hline Ukrzyżowanie & $\begin{array}{l}\text { X w. p.n.e.- } \\
\text { XII w. }\end{array}$ & $\begin{array}{l}\text { Egzekucja złoczyńców, } \\
\text { zbrodniarzy i niewolników }\end{array}$ & $\begin{array}{l}\text { Europa, Afryka, Azja } \\
\text { (Fenicja, Grecja, } \\
\text { Rzym, Asyria, Egipt, } \\
\text { Persja, Japonia) }\end{array}$ \\
\hline $\begin{array}{l}\text { Śmierć } \\
\text { męczeńska } \\
\text { chrześcijan }\end{array}$ & $\begin{array}{l}\text { staro- } \\
\text { żytność }\end{array}$ & $\begin{array}{l}\text { Pożarcie przez zwierzęta, } \\
\text { ukrzyżowanie, całopalenie }\end{array}$ & Cesarstwo rzymskie \\
\hline Pojedynek & do XIX w. & $\begin{array}{l}\text { Pojedynek stron spornych kończył } \\
\text { się z reguły okaleczeniem lub } \\
\text { śmiercią }\end{array}$ & Europa, Azja \\
\hline Inkwizycja & XI-XVIII w. & $\begin{array}{l}\text { Całopalenie, ćwiartowanie, topie- } \\
\text { nie (np. heretyków, czarownic) }\end{array}$ & $\begin{array}{l}\text { Europa (Anglia, } \\
\text { Szkocja, Francja, } \\
\text { Niemcy, Włochy), } \\
\text { Ameryka Pn. (Salem) }\end{array}$ \\
\hline Banicja & do XIX w. & $\begin{array}{l}\text { Publiczna deportacja, śmierć } \\
\text { w wyniku chorób i wycieńczenia }\end{array}$ & Świat \\
\hline Niewolnictwo & do XX w. & $\begin{array}{l}\text { Śmierć publiczna jako kara za } \\
\text { przewinienie, ofiary rytualne }\end{array}$ & $\begin{array}{l}\text { Świat (Ameryka, } \\
\text { Azja) }\end{array}$ \\
\hline $\begin{array}{l}\text { Publiczne } \\
\text { tortury } \\
\text { i okaleczanie }\end{array}$ & do XIX w. & Dyby, pręgierze & Świat (Francja, Rosja) \\
\hline $\begin{array}{l}\text { Publiczne } \\
\text { egzekucje }\end{array}$ & do XXw. & $\begin{array}{l}\text { Łamanie kołem, garot, wieszanie, } \\
\text { ścięcie głowy mieczem, gilotyną, } \\
\text { krzesło elektryczne, komora gazo- } \\
\text { wa, rozstrzelanie }\end{array}$ & $\begin{array}{l}\text { Świat (Anglia - } \\
\text { Tyburn, Szkocja, } \\
\text { Francja, Niemcy, } \\
\text { Rosja) }\end{array}$ \\
\hline $\begin{array}{l}\text { Publiczne } \\
\text { sekcje zwłok }\end{array}$ & XVI-XX w. & Sekcja, członkowanie ciała & Europa, Ameryka \\
\hline $\begin{array}{l}\text { Dokumentacja, } \\
\text { inscenizacja } \\
\text { i rekonstrukcja } \\
\text { śmierci }\end{array}$ & $\begin{array}{l}\text { od średnio- } \\
\text { wiecza }\end{array}$ & $\begin{array}{l}\text { Muzea makabry, strachu, wyda- } \\
\text { rzenia inscenizujące śmierć, kolek- } \\
\text { cje artefaktów związanych ze } \\
\text { śmiercią i cierpieniem }\end{array}$ & Świat \\
\hline $\begin{array}{l}\text { Śmierć realnie } \\
\text { bliska jako } \\
\text { atrakcja }\end{array}$ & od XIX w. & $\begin{array}{l}\text { Uczestnictwo w niebezpiecznych } \\
\text { wydarzeniach, obecnośc w nie- } \\
\text { bezpiecznych miejscach }\end{array}$ & Świat \\
\hline
\end{tabular}

Źródło: opracowanie własne.

W średniowieczu upowszechniły się pojedynki gromadzące widzów, podczas których strony sporne walczyły ze sobą wykorzystując ustaloną broń, a przegrany, który niejednokrotnie doznawał uszczerbku na zdrowiu 
lub ponosił śmierć, był uznawany za winnego. Całopalenie było w tym okresie karą stosowaną wobec podpalaczy, heretyków i podejrzanych o uprawianie czarów. Kara ta była popularna w całej Europie, w której od XI do XVIII wieku według szacunków spalono około 200 tysięcy ludzi (FARRINGTON 1997, s. 32). W Europie całopalenie stało się popularną formą karania czarownic i podejrzanych o likantropię. Również na terenie dzisiejszej Polski mamy przykłady historycznie potwierdzonych aktów śmierci wykonywanych na czarownicach, m.in. w Nysie w XVII wieku był wybudowany specjalny piec służący tym celom. W Stanach Zjednoczonych najbardziej znanym miejscem egzekucji czarownic jest miasteczko Salem, w którym w 1692 roku doszło do procesów o czary, ofiarami których były również dzieci.

Kary średniowieczne były częstokroć bardzo okrutne, m.in. ze względu na widowiskowość. Najpopularniejszą w Europie karą śmierci było powieszenie, zarezerwowane dla pospolitych przestępców, i śmierć przez ścięcie, poczytywane za lepszy rodzaj śmierci, przeznaczony dla szlachetnie urodzonych. Wielokrotnie zwłoki wisielców bądź głowy nabite na tyki były eksponowane przy wjeździe do miasta, pełniąc funkcję prewencyjną, znaku ostrzegającego przed konsekwencjami przestępstw. Publicznym karom i egzekucjom towarzyszyły festyny, zabawy, jarmarki wraz z określonym scenariuszem egzekucji rozpoczynającego się od przeprowadzenia skazanego na szafot, a kończącego się aktem uśmiercenia. Widowiska te gromadzily nie tylko mieszkańców, ale również przyjezdnych (turystów?). W Londynie wątpliwą popularność zyskało miasto Tybrun, w którym wieszano skazańców od 1220 do 1783 roku (FARRINGTON 1997, s. 164). Widowiska stały się tak popularne, że wybudowano nawet wokół szubienicy trybuny.

W roku 1792 wprowadzono we Francji do użytku gilotynę. Choć podobnych urządzeń używali już Persowie $\mathrm{w} X$ wieku, a z czasem trafiła do innych krajów, w których była wykorzystywana do publicznych egzekucji, to największą „popularność” święciła we Francji, aż do lat dwudziestych XX wieku. Jej różne przedstawienia były popularną pamiątką z egzekucji będących powszechnym widowiskiem, często reglamentowanym biletami wstępu. Produkowano małe gilotyny sprzedając je jako zabawki dla dzieci czy pamiątki. Za sprawą gilotyny sławę zdobyło muzeum figur woskowych Madame Tussaud (urodzonej w Szwajcarii Marii Grosholtz), która na 10 lat przed rewolucją francuską przeniosła się do Paryża z zamiarem zorganizowania wystawy figur woskowych. W 1783 roku doktor Philip Curtius otworzył Caverne des Grands Voleurs i wystawił tam podobizny znanych ówczesnych kryminalistów. Maria Grosholtz będąc jego asystentką wykonywała woskowe maski ofiar egzekucji. Po śmierci Curtisa Maria przeniosła się do Londynu. Przez lata podróżowała po Anglii, Szkocji i Irlandii pokazując 
swoją wystawę, jednocześnie zdejmując maski słynnych brytyjskich zbrodniarzy. Były to początki pierwszego popkulturowego muzeum grozy w Wielkiej Brytanii.

Wiek XX przyniósł zakaz publicznych egzekucji w krajach kultury zachodniej. Współcześnie quasi-publiczne egzekucje wykonywane są nadal w USA, ograniczone do wąskiego grona przedstawicieli opinii publicznej i władzy. Publiczna kara śmierci zachowała się w takich krajach, jak m.in. Pakistan, Libia, Arabia Saudyjska, Burundi, Gwinea czy Chiny (WARYLEWSKI 2007, s. 126).

Bazując na historii kary śmierci i tortur od XIX wieku zaczęły powstawać na całym świecie obiekty dokumentujące śmierć i tortury, jak również gromadzące artefakty z tym związane. $Z$ czasem stały się one atrakcjami i produktami turystycznymi.

\section{Artefakty śmierci}

Powszechnymi artefaktami śmierci są eksponowane publicznie szczątki ludzkie zarówno kostne, jak i cielesne, są nimi również dzieła sztuki malarskiej, rzeźbiarskiej, literatury i muzyki, przedstawienia i wydarzenia artystyczne niosące szeroki przekaz o marności ludzkiego życia. W tym aspekcie należy prześledzić rozwój sztuki, której produkty można zaklasyfikować do wytworów kultury śmierci, a stanowiących przedmiot zainteresowania turystycznego.

W wieku XVII fenomen śmierci powrócił do dyskursu publicznego w postaci martwego ciała (trupa), które stało się głównym obrazem śmierci (ARIÈs 1989, s. 346). Sekcja i balsamowanie zwłok stanowily przyczynek do uznania trupa za obiekt godny podziwu. Tym samym oprócz zmarłego człowieka, kościotrupa i rozkładających się zwłok pojawiała się w sztuce anatomia ciała. W XIV stuleciu w Padwie (ok. 1340 r.) przeprowadzono prawdopodobnie pierwszą publiczną sekcję zwłok (BARAŃSKI 2000, s. 53). W epoce odrodzenia popularne były sekcje zwłok, podczas których medycy poznawali ciało ludzkie, studenci zgłębiali wiedzę medyczną, a publiczność napawała się drastycznymi scenami. Moda na publiczne prezentacje „żywej” anatomii ciała rozwijała się począwszy od XVI wieku, z kulminacją w wiekach XVII i XVIII. Powszechna publiczna sekcja zwłok była w tym czasie swoistym teatrem i rozrywką dla zgromadzonych widzów. Budowano teatry anatomiczne, dostosowywano pomieszczenia do oglądu audytoryjnego, sprzedawano bilety wstępu i pamiątki. Był to rodzaj rozrywki, która występuje również współcześnie, ale odbywa się w nieco inny sposób, czego przykładem są wystawy preparowanych ciał „Body Worlds”. 
Przekonanie, że trup nie może po prostu zniknąć, że trzeba go konserwować, pokazywać i oglądać spowodowało w XVII wieku zmianę w podejściu do umarłych. Zakonnicy, w szczególności kapucyni i franciszkanie, trudnili się m.in. mumifikacją ciał, które po odpowiednim przygotowaniu i osuszeniu eksponowane były $\mathrm{w}$ „kostnicach mumii" odwiedzanych przez żądnych emocji gości (ARIÈs 1989, s. 374). Ten sposób przyciągania ludzkiej uwagi przetrwał do XIX stulecia.

Ciało zmarłego poddawane było od najdawniejszych czasów zabiegom mającym na celu staranne jego zachowanie, najczęściej ze względów praktycznych lub religijnych. Ciało mogło być przypadkowo uchronione przed rozkładem, mogło zostać celowo zakonserwowane lub w sposób naturalny nie podlegać rozkładowi. W tym ostatnim przypadku ludzkość odwoływała się do wierzeń religijnych, najczęściej wyjaśniając brak rozkładu ingerencją nadprzyrodzonych sił (tab. 7).

Tab. 7. Przykładowe miejsca na świecie, gdzie odnajdywano mumie

\begin{tabular}{|l|l|}
\hline \multicolumn{1}{|c|}{ Kategoria miejsca } & \multicolumn{1}{c|}{ Geograficzna lokalizacja } \\
\hline Torfowiska & Europa - Anglia, Irlandia, Holandia, Niemcy, Dania \\
\hline Lodowce & Grenlandia, Alpy, Himalaje, północna Azja, Europa i Ameryka Pn. \\
\hline Jaskinie & Ameryka Północna - Arizona, Alaska, Aleuty \\
\hline Jaskinie grobowce & $\begin{array}{l}\text { Ameryka Południowa - Kolumbia, Ekwador, Peru (Lima, Ancon), } \\
\text { Chile, Argentyna, Boliwia, Meksyk (Cuzco) }\end{array}$ \\
\hline Grobowce, piramidy & Afryka - Egipt (Dolina Królów, Tanis, Baharija) \\
\hline Grobowce & Azja - Chiny (Kotlina Kaszgarska), Japonia, Mongolia \\
\hline $\begin{array}{l}\text { Grobowce, krypty, } \\
\text { świątynie, mauzolea }\end{array}$ & Europa - Palermo, Neapol, Kijów, Tuluza, Bordeaux \\
\hline
\end{tabular}

Źródło: opracowanie własne.

Miejsc odnajdywania zakonserwowanych ciał jest na świecie wiele. Naturalnie zmumifikowane zwłoki odnajdywane są np. na torfowiskach północno-zachodniej Anglii, zachodniej Irlandii, Holandii, Niemiec, Danii, na obszarach suchych w północnej Afryce - Egipcie, Azji Zachodniej i Środkowej lub w zimnych regionach Azji Północnej i Europy Północnej. Egipt słynie z mumii faraonów, wraz z turystycznie odwiedzaną Doliną Królów, w grobach których odnajdywano bardzo dobrze zabalsamowane ciała faraonów, kapłanów i członków ówczesnej arystokracji. Mumie pochodzące z Egiptu można znaleźć w wielu miejscach na całym świecie (tab. 8).

Mumie odnajdywane są w wielu miejscach Ameryki Północnej i Południowej, najczęściej na obszarach górskich i w jaskiniach oraz na suchych równinach. Obszary znane z odnajdywania mumii Indian i plemion zamieszku- 
jących niegdyś obszary Andów, Kordylierów i równin amerykańskich to Arizona, Alaska, Kolumbia, Ekwador, Peru, Chile, Argentyna i Boliwia. W suchym powietrzu andyjskim, podobnie jak w Egipcie, proces mumifikacji przebiegał naturalnie. Na obszarze Chin na pustyni Takla Makan odnajdywane są mumie naturalnie zakonserwowane w suchym klimacie pustynnym Kotliny Kaszgarskiej (KWIATKOWSKI 2005). Mumie odkrywane były też na obszarze Japonii, Wysp Kanaryjskich, wysp Oceanu Indyjskiego, Grenlandii i w Europie, gdzie mumifikacja była popularna od wczesnego średniowiecza (rys. 14).

Tab. 8. Wybrane miejsca na świecie ekspozycji mumii egipskich

\begin{tabular}{|l|l|}
\hline \multicolumn{1}{|c|}{ Muzeum } & \multicolumn{1}{c|}{ Kraj } \\
\hline Muzeum Brytyjskie - Londyn & Anglia \\
\hline Muzeum Historii Naturalnej - Londyn & Anglia \\
\hline Muzeum Miasta Manchester - Manchester & Anglia \\
\hline Muzeum Mumifikacji - Luksor & Egipt \\
\hline Muzeum Egipskie - Kair & Egipt \\
\hline Muzeum Luwr - Paryż & Francja \\
\hline Muzeum Historii Naturalnej - Lyon & Francja \\
\hline Narodowe Muzeum Starożytności - Lejda & Holandia \\
\hline Muzeum Królewskie Ontario - Toronto & Kanada \\
\hline Muzeum Egipskie - Berlin & Niemcy \\
\hline Muzeum Archeologiczne - Kraków & Polska \\
\hline Muzeum Archeologiczne - Poznań & Polska \\
\hline Muzeum Narodowe - Warszawa & Polska \\
\hline Narodowe Muzeum Historii Kultury - Pretoria & RPA \\
\hline Muzeum Narodowe Szkocji - Edynburg & Szkocja \\
\hline Metropolitan Museum of Art - Nowy Jork & USA \\
\hline Brooklin Museum - Nowy Jork & USA \\
\hline Muzeum Egipskie - Turyn & Włochy \\
\hline
\end{tabular}

Źródło: opracowanie własne.

Zmumifikowane ciała pokazywano na jarmarkach, gromadzili je kolekcjonerzy. Zachowane od rozkładu ludzkie ciało budziło zawsze sensację, jednak u współcześnie żyjących ludzi śmierć i martwe ciało wywołują zazwyczaj negatywne skojarzenia. Na świecie eksponowano publicznie ciała zabalsamowanych polityków, takich jak Włodzimierza Lenina i Józefa Stalina w Moskwie, Ho Chi Minh, Mao Zedong, Kim Ir Sen. Wiele ciał znajduje się w świątyniach, mauzoleach, muzeach, znane są przecież mumie klasztorne (Palermo, Ławry Peczorskiej w Kijowie, klasztoru Reformatów w Krakowie). Wiele ciał ludzkich to współczesne cenne eksponaty muzealne, często będące główną atrakcją dla odwiedzających i przynoszące znaczne dochody (tab. 9). 


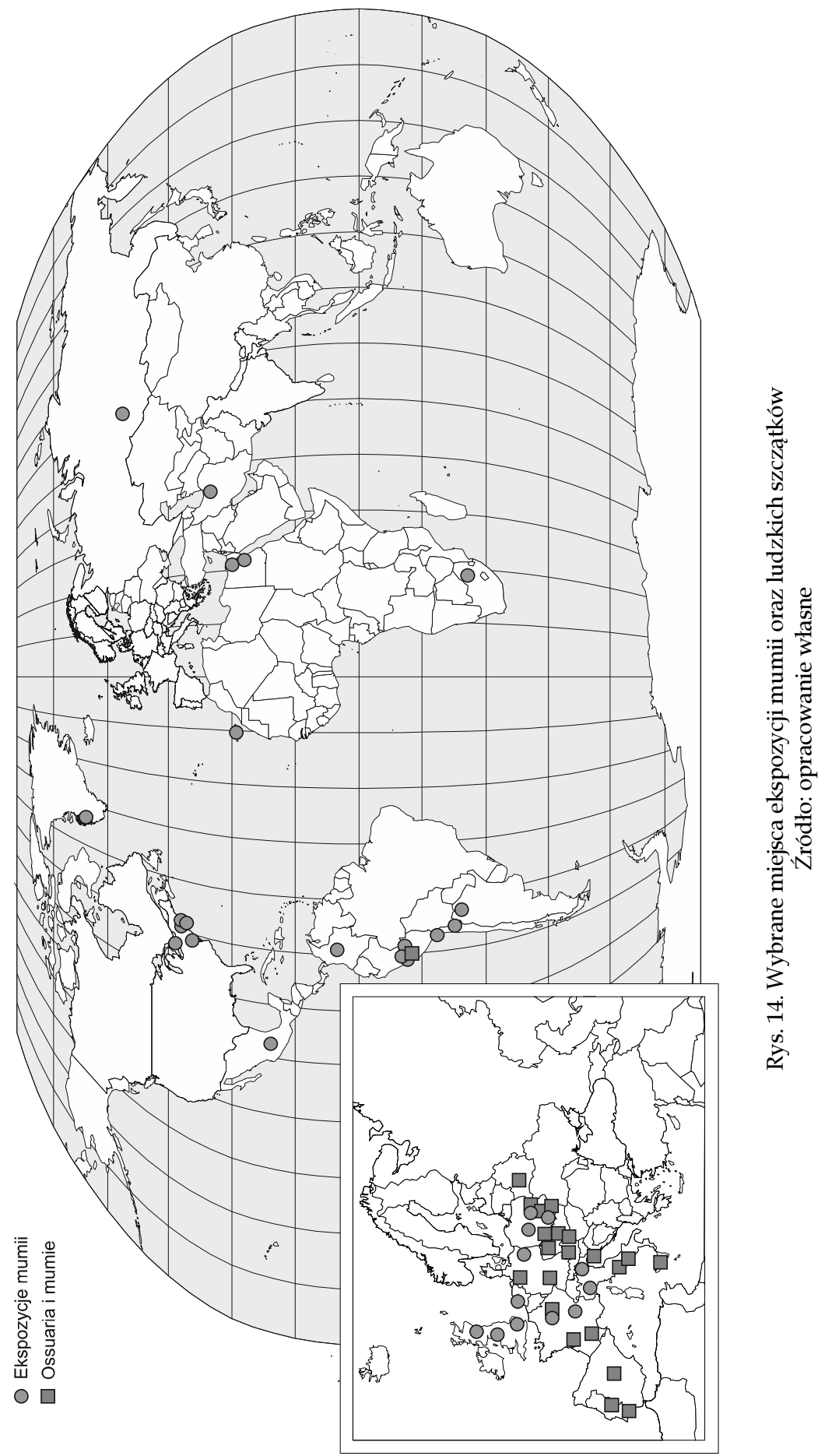


Tab. 9. Wybrane muzea na świecie z ekspozycjami mumii

\begin{tabular}{|l|l|}
\hline \multicolumn{1}{|c|}{ Muzeum } & \multicolumn{1}{c|}{ Kraj } \\
\hline Museo de Arqueología de Alta Montaña - Salta & Argentyna \\
\hline Muzeum San Pedro - San Pedro de Atacama & Chile \\
\hline Muzeum Cuzco - Cuzco & Ekwador \\
\hline Muzeum Narodowe Grenlandii - Nuuk & Grenlandia (Dania) \\
\hline Muzeum Narodowe Iranu - Teheran & Iran \\
\hline Muzeum Narodowe - Bogota & Kolumbia \\
\hline Muzeum Mumii - Guanajuato & Meksyk \\
\hline Muzeum Archeologii i Antropologii - Lima & Peru \\
\hline Muzeum Narodowe - Lima & Peru \\
\hline Muzeum Archeologiczne - San Miguel de Azapa & Peru \\
\hline Muzeum Archeologiczne i Etnograficzne - Nowosybirsk & Rosja \\
\hline Museo de la Naturaleza y el Hombre - Santa Cruz de Tenerife & Teneryfa \\
\hline Muzeum Narodowe i Historii Naturalnej - Waszyngton & USA \\
\hline Amerykańskie Muzeum Historii Naturalnej - Nowy Jork & USA \\
\hline Muzeum Archeologiczne - Bolzano & Włochy \\
\hline
\end{tabular}

Źródło: opracowanie własne.

Obrzędy związane ze śmiercią pozwalają żywym znaleźć się w sytuacji bezpośredniego kontaktu ze zjawiskiem śmierci. Zwłoki są ciągłym przypomnieniem osoby zmarłej, jednocześnie podmiotem licznych wyobrażeń związanych ze śmiercią. Martwe ciało jest również przedmiotem wielu różnorodnych zabiegów rytualnych, których charakter zależy od przestrzeni kulturowej, w której się rozgrywają (GRYGLEWSKI 2005, s. 66).

Społeczności oddalone i odizolowane od siebie geograficznie i historycznie poddawały ciała zmarłych mumifikacji nadając samemu procesowi, jak również zabalsamowanym zwłokom określoną wartość symboliczną. Kościół chrześcijański dbał o właściwe zabezpieczenie ciała zmarłych, których życie i śmierć nabierała znamion świętości. Popularny od średniowiecza kult świętych i związanych z nim tradycji tworzenia relikwiarzy sprzyjał mumifikacji ciał. W samych Włoszech jest co najmniej 25 zmumifikowanych ciał osób uznanych przez chrześcijan za świętych (GRYGLEWSKI 2005, s. 191).

W Europie zmumifikowane ciała turysta odnajdzie najczęściej w kryptach kościelnych i mauzoleach. Przykładem mogą być mumie z Sycylii, przechowywane w kościele Kapucynów w Palermo (ok. 8000), kościołach w Savoca, Venzone, Comiso i Neapolu.

Funkcję, jaką pełniły kostnice (ossuaria) podlegały zmianom. Początkowo były to magazyny, które pozwalały pozbyć się wykopanych na cmentarzach lub z grobów kości, poczynając od XIV stulecia, pod wpływem wzrastającego zainteresowania makabrycznością, były wykorzystywane w religijnym 
przekazie memento mori. Kostnice, takie jak Santa Maria Della Concezione w Rzymie, stały się rodzajem dekoracji, w której kości ludzkie stały się częścią artystycznych instalacji sztuki barokowej i rokokowej, gdzie szczątki ludzkie stanowily element widowiska sakralnego (tab. 10).

Tab. 10. Wybrane ossuaria oraz miejsca ekspozycji mumii i ludzkich szczątków na świecie

\begin{tabular}{|l|l|}
\hline \multicolumn{1}{|c|}{ Miejsce ekspozycji } & \multicolumn{1}{c|}{ Kraj } \\
\hline Kościół św. Stefana - Wiedeń & Austria \\
\hline Kaplica św. Michała - Hallstatt & Austria \\
\hline Kościół Bożego Ciała - Nieśwież & Białoruś \\
\hline Kościół św. Błażeja - Vodnjan & Chorwacja \\
\hline Kaplica Wszystkich Świętych - Kutna Hora & Czechy \\
\hline Kościół Kapucynów - Brno & Czechy \\
\hline Saint Denis - Paryż & Francja \\
\hline Kościół Kordelierów - Tuluza & Francja \\
\hline Kościół Saint Michel - Bordeaux & Francja \\
\hline Katakumby - Paryż & Francja \\
\hline Escorial - San Lorenzo de El Escorial & Hiszpania \\
\hline Katedra - Brema & Niemcy \\
\hline Kaplica św. Michała - Oppenheim & Niemcy \\
\hline Katakumby św. Franciszka - Lima & Peru \\
\hline Kościół św. Jana - Warszawa & Polska \\
\hline Kościół Reformatów - Kraków & Polska \\
\hline Kaplica Czaszek - Czermna (Kudowa Zdrój) & Polska \\
\hline Kościół św. Krzyża - G. Świętokrzyskie & Polska \\
\hline Kaplice Kości - Evora, Faro & Portugalia \\
\hline Ławra Peczarska - Kijów & Ukraina \\
\hline Klasztor Kapucynów - Palermo & Włochy \\
\hline Bazylika św. Dominika - Neapol & Włochy \\
\hline Kościół Santa Maria Della Concezione - Rzym & Włochy \\
\hline Katakumby - Rzym & Włochy \\
\hline Katakumby - Neapol & Włochy \\
\hline
\end{tabular}

Źródło: opracowanie własne.

Odkrywanie śmierci poprzez artyzm ma bogatą historię. Początkowo, od XI wieku śmierć w europejskiej sztuce plastycznej była personifikowana w postaci zmarłego człowieka. Począwszy od średniowiecza, kiedy widok martwego ciała był codziennością, zmysł wzroku odgrywał niebagatelną rolę w percypowaniu śmierci. Dopiero w XV i XVI stuleciach upowszechnił się kościotrup, szkielet i rozkładające się ciało (vanitas). Średniowieczny "taniec śmierci" był inspirowany codzienną makabrą wyobraźni - umierający ludzie 
na ulicach, ofiary wojen i chorób, powszechność ekshumacji na cmentarzach, obyczajowość pochówku, publiczna kaźń i egzekucja. Wpływało to na powszechność śmierci, która była doznawana wieloma zmysłami. Jednocześnie taniec, jako ekspresja ludu, ciemna strona ludzkiej zmysłowości, był obecny powszechnie - zarówno w miejscach sakralnych, jak i asakralnych. Motyw "tańca śmierci”, łączący wizerunek śmierci tańczącej z ludźmi, upowszechnił się w Europie wraz z pojawieniem się fresków kościelnych w opactwie La Chaise Dieu w Owerni (1390-1410) czy malowideł w krużgankach cmentarza św. Niewiniątek w Paryżu (1424) (BARAŃSKI 2000, s. 18). Motywami ars moriendi, triumfu śmierci i „tańca śmierci” ozdabiane były krużganki klasztorów, ściany kostnic lub kościołów (w Polsce motyw „tańca śmierci” odnajdziemy m.in. w kościele Bernardynów w Krakowie, w klasztorze w Kalwarii Pacławskiej koło Przemyśla, w kaplicy Pana Jezusa w kościele parafialnym w Tarłowie). Średniowieczne ars moriendi było początkiem dyskursu o formie wyobrażeń śmierci personifikowanej, artystycznej wizji przenoszonej w sferę obrazu. Od wieku XII przez cztery stulecia ikonografia ukazywała tematy o kresie życia. Pojawiały się sceny Sądu Ostatecznego, Apokalipsy, przeludnionego piekła i strzegącego anioła. W wiekach XIV-XVI dominowały w sztuce odpychające obrazy rozkładu, nagie zwłoki toczone przez robactwo, zwane transi, "ozdabiały” w tym czasie grobowce. Widowiska pasyjne, kalwarie, groby pańskie były wszechobecne w średniowiecznej i nowożytnej Europie, stanowiąc również współcześnie zespół artefaktów religijno-artystycznych oddziałujących na zmysły wiernych (KURYLUK 2002, s. 75-77).

Renesans, pomimo apoteozy życia, również niósł ze sobą śmierć w sztuce, szczególnie w aspekcie upamiętnienia umarłej osoby w pozie jak najbardziej urzeczywistniającej jej żywot. Sztuka baroku była pełna symboliki eschatologicznej, nakazów, nauk. Atrybuty śmierci - czaszka, kościotrup, demony, diabły, anioły i święci - sytuowano w malarstwie w określonej konwencji nauki drogi właściwego postępowania. Barokowa sztuka wanitatywna (KAZBERUK 2012, MOISAN-JABŁOŃSKA 2001) miała również swoje odbicie w malarstwie, rzeźbie i w sakralnej sztuce użytkowej - ornatach, sztandarach, trumnach, katafalkach. W XVII wieku motywem przewodnim ikonografii było ponadto zmartwychwstanie. Oświecenie wprowadziło do malarstwa temat medykalizacji śmierci, anatomii ciała ludzkiego, demonstracji zwłok (np. malarstwo Rembrandta - lekcje anatomii doktora Tulpa i doktora Dejmana), natomiast romantyzm - fascynację makabrą, sensacyjnością śmierci i fantazmatami. Makabryczne dekoracje wywoływały lęk przed śmiercią, a portrety zmarłych powodowały złudzenie śmierci. Wniosek z tego, że sztuka prezentująca śmierć już w średniowieczu i później budziła emocje podob- 
ne do tych, jakie dziś wywołują obrazy okrucieństwa i makabrycznej śmierci. Cel był i jest ten sam - wywołać lęk przed śmiercią i szacunek do życia.

Wyrazem kulturowego i społecznego stosunku do śmierci w XIX stuleciu była sztuka sepulkralna (cmentarna, grobowa), przejawiająca się w rzeźbie nagrobnej, począwszy od prostych płyt nagrobnych, po dekoracyjne kaplice grobowe i alegoryczne epitafia. W Polsce szczególną rolę odegrał sarmacki portret trumienny (DZIUBKOWA, red. 1996). XVIII i XIX wiek to czas śmierci bohatera, śmierci za ojczyznę, tematyki bitewnej w sztukach plastycznych. Jednak powoli, wraz z końcem XIX stulecia zaczęło pojawiać się tabu śmierci w sztuce i zastępowanie wyrazistego jej obrazu alegorią (PIEŃKOS 1996).

Pierwsza wojna światowa ukazała bezsensowność śmierci, która pozostała w pamięci poprzez mogiły i cmentarze wojenne. Podobnie II wojna światowa stała się $\mathrm{w}$ konsekwencji przyczyną odrzucenia tematyki śmierci w sztuce europejskiej, z wyjątkiem przestrzeni pamięci. Śmierć powróciła w sztuce, szczególnie w filmie i literaturze, w drugiej połowie wieku XX. Jest to jednak odmienny od historii obraz śmierci okrutnej, widowiskowej, makabrycznej, wręcz uwielbienie okrucieństwa społeczeństwa lat sześćdziesiątych XX wieku i późniejszych, objawiające się pociągiem do krwi, przestępstw, wypadków drogowych, katastrof.

Temat śmierci we współczesnej sztuce jest nadal powszechny (GUTOWSKI 2002, LEWANDOWSKI 2004). Artystyczna wizja śmierci jest często kontrowersyjna, przekracza określone granice moralności, szokuje. Wystawy „Body Worlds" Gintera von Hagensa, prezentujące spreparowane ciała ludzkie i zwierzęce, wzbudzają jednocześnie opór i zachwyt. Obcowanie z preparowanymi ciałami jest wzmacniane możliwością zakupu pocztówek, albumów, koszulek. G. KAZBERUK (2012) zwraca uwagę na niebezpieczeństwo, jakie pojawiło się wraz z wystawami von Hagensa. Precedensem jest wprowadzenie trupa do galerii, uczynienie go tworzywem sztuki i estetyzacja śmierci. Ciała są kształtowane, tak aby się podobały.

Do artystycznego przedstawiania "fikcyjnej" śmierci, śmierci historycznej, ale odtwarzanej „na niby” można również zaliczyć widowiskowe rekonstrukcje historyczne, w trakcie których prezentowana jest śmierć - mord, walka, cierpienie.

Wytwory sztuki artystycznej będące szczególnym walorem turystycznym stanowią często o atrakcyjności pobytu turystycznego. Oglądanie dzieł artystycznych niesie ze sobą rozmaite cele i motywy, w tym memoratywne, edukacyjne, wychowawcze, socjalizacyjne, estetyczne, emocjonalne i rozrywkowe. Opisane przykłady wizji śmierci są potwierdzeniem jej widowiskowego, częstokroć makabrycznego charakteru oraz związku śmierci ze sztuką, odkrywanych w trakcie podróży kulturowych i tanatoturystycznych. 


\subsection{GEOGRAFIA ŚMIERCI}

Analizowana do tej pory kultura śmierci, w szczególności jej wytwory, które decydują o zainteresowaniu poznawczym zarówno religijnym, historycznym, jak i turystycznym jest różnicowana geograficznie. $Z$ tego względu należy rozważyć przestrzenne uwarunkowania, determinujące charakter i specyfikę określonych elementów kultury śmierci, poprzez próbę konceptualizacji geografii śmierci, stanowiącej wyodrębniony ze względu na przedmiot badań, obszar geografii człowieka i geografii humanistycznej.

\subsubsection{PRZESTRZEŃ ŚMIERCI}

Przestrzeń jest kluczową kategorią koncepcji teoretycznych i metodologicznych w geografii. Kultura w znaczeniu antropologicznym ma wymiar przestrzenny. Istotnym terminem dla relacji kultura-przestrzeń jest obszar kulturowy, nawiązujący do pojęcia "region geograficzny”, na terenie którego można zidentyfikować kulturowe cechy grupy ludzkiej (REMBOWSKA 2002b, s. 99). Granice obszarów kulturowych są płynne, nieciągłe. Nakładają się one przestrzennie na siebie bądź przecinają się wewnątrz obszarów kulturowych, co stwarza trudności w procesie ich delimitacji. Kultury mają często określone jedynie granice społeczne, a nie przestrzenne.

Obszar kulturowy wiąże się z rozprzestrzenianiem cech kulturowych, a więc aspektem dyfuzji i dystrybucji przestrzennej elementów kultury. Każda kultura (również kultura śmierci) jest wytworem niezliczonych innowacji, które rozprzestrzeniają się z miejsca ich pochodzenia i obejmują coraz większe obszary. Badanie dyfuzji skupia się na mechanizmach przemieszczania się elementów kultury, które są bardziej bądź mniej podatne na dyfuzję (CZARNOWSKI 1956, KŁOSKOWSKA 2005).

Jedną z form dyfuzji kulturowej jest akulturacja zachodząca wówczas, gdy w bliski kontakt wchodzą dwa odmienne społeczeństwa, które dzieli znaczny dystans kulturowy, społeczny lub geograficzny. Proces ten polega na gwałtownym przeobrażeniu się jednej kultury pod wpływem innej lub pod wpływem zmienionych warunków społecznych bądź środowiskowych (REMBOWSKA 2002b, s. 103). Następstwem dyfuzji jest synkretyzm kulturowy, który polega na wiązaniu się $\mathrm{w}$ jednorodne całości elementów pochodzących z różnych kultur.

Przestrzeń kulturowa $w$ geografii człowieka może być ujmowana jako przestrzeń fizyczna, będąca nosicielem znaczeń, lub przestrzeń formalna. Podstawy koncepcji przestrzeni kulturowej znajdziemy w fenomenologii. Człowiek dzięki tworzeniu znaczeń i symboli adaptuje się do świata rzeczy. 
Zdolność porządkowania rzeczy poprzez nadawanie im określonych wartości i znaczeń zapewnia społeczeństwu porządkowanie świata, co z kolei ma wpływ na kontrolę nad nim i poczucie sensu życia (REMBOWSKA 2006).

W przeciwieństwie do geografii człowieka geografia humanistyczna określa przestrzeń przez włączenie subiektywnej oceny. W sensie ontologicznym przestrzenność jest relacją bycia, która łączy człowieka z miejscem (KACZMAREK 2005). Geografia humanistyczna wprowadziła pojęcie przestrzeni doświadczonej, której istotą jest jej rozumienie (JĘDRZEJCZYK 2001, 2008).

Dla rozważań podejmowanych $\mathrm{w}$ niniejszej pracy istotna jest przestrzeń realna, z której wyodrębniona została przestrzeń niefizyczna (relacyjna), heteroteliczna. $W$ ramach przestrzeni niefizycznej można wyróżnić przestrzeń fenomenalną, a w niej z kolei ekologiczną, społeczną i kulturową. Wszystkie trzy wymienione przestrzenie stanowią przedmiot podjętych badań $\mathrm{z}$ wyróżnieniem przestrzeni kulturowej (rys. 15 i 16).

Krajobraz kulturowy jest formą obrazu przestrzeni, która można interpretować jako zapis działalności człowieka w środowisku geograficznym (MYGA-PIĄTEK, red. 2001, 2005). Geografia krajobrazu kulturowego wiąże się obecnie z działaniami na rzecz rozwoju zrównoważonego i ze stałym pogarszaniem się warunków życia człowieka (RICHLING 2008, OSTASZEWSKA 2002, WOJCIECHOWSKI 1986). Badania geografów dotyczą również zagadnień percepcji krajobrazu kulturowego, tożsamości kulturowej i różnic w zachowaniach społecznych. W kontekście krajobrazu kulturowego należy rozpatrywać istotę geografii kultury, której reprezentanci zajmują się przestrzennym

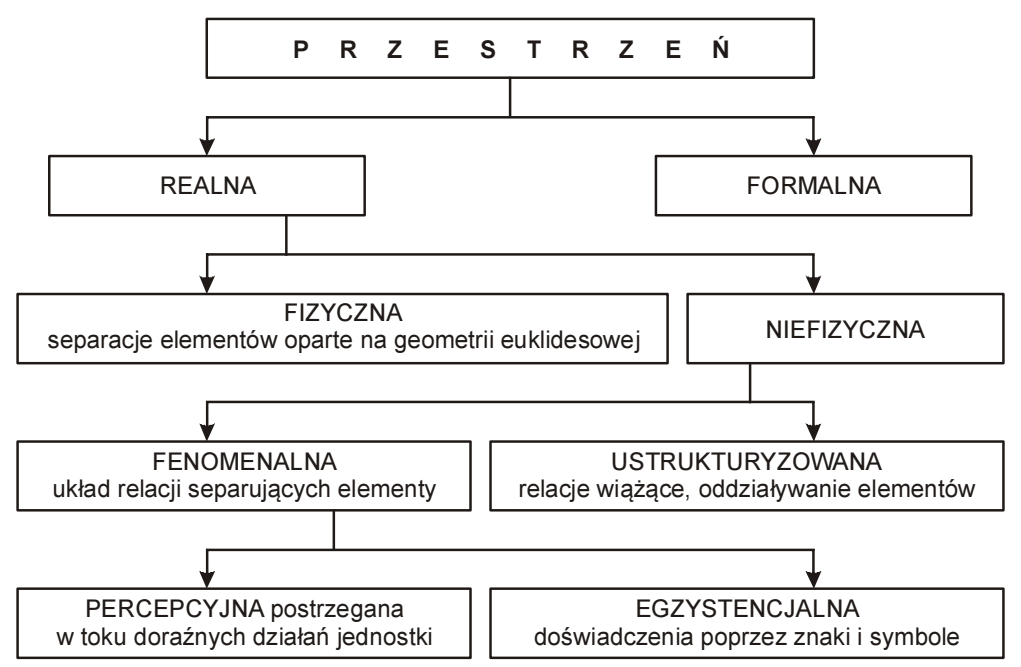

Rys. 15. Typologia przestrzeni w geografii społeczno-ekonomicznej Źródło: A. LISOWSKI (2003, s. 39; na podstawie Z. Chojnicki 1999) 


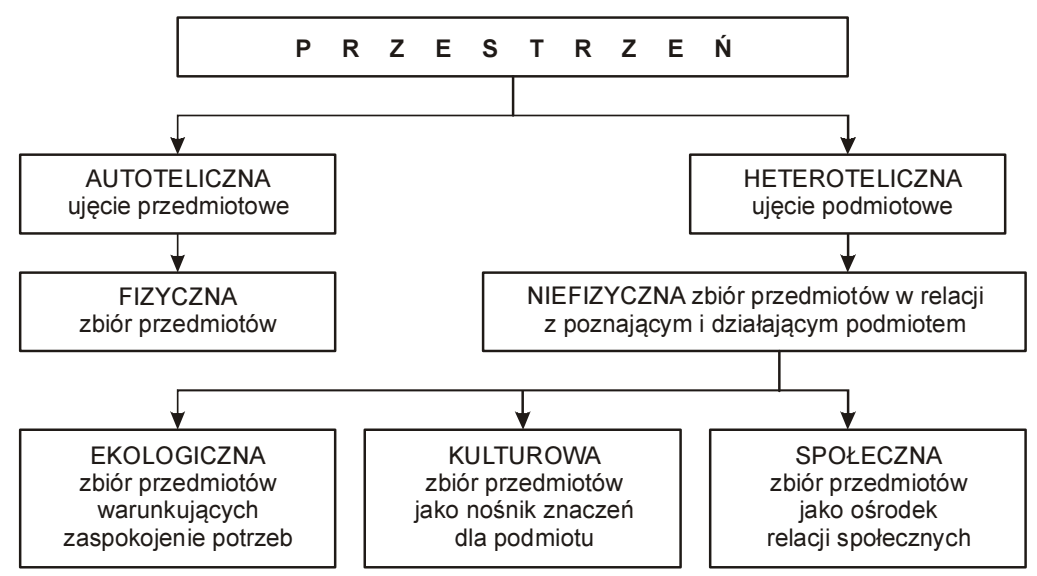

Rys. 16. Podstawowe typy przestrzeni w geografii człowieka Źródło: A. LISOWSKI (2003, s. 44)

zróżnicowaniem kultur wynikającym z procesu poszerzania ekumeny (REMBOWSKA 2002a). W ramach krajobrazu kulturowego można wyróżnić krajobraz, w którym identyfikowana jest pamięć o śmierci. Tym samym analogicznie można wyróżnić w ramach geografii kultury geografię śmierci.

Fenomenologiczna interpretacja przestrzeni śmierci dotyczy roli ludzkiego doświadczenia, które decyduje o klasyfikacji przestrzeni i jej zróżnicowaniu (KOLBUSZEWSKI 1994). Przestrzeń śmierci dzielić możemy na dwie sfery: sacrum i profanum. Sacrum jest absolutne, profanum względne i nierzeczywiste. Pozazmysłowy świat śmierci przeciwstawia sobie zmysłowy i praktyczny świat zjawisk. Miejsca sacrum śmierci stanowią wzorzec porządku świata, czego przykładem jest chociażby miejsce śmierci Jezusa (ELIADE 1993). Miejsca świeckie pozbawione są świętości, czego przykładem może być laicki wizerunek śmierci w obiektach muzealnych.

We współczesnej kulturze doświadczamy fundamentalnej zmiany w rozumieniu śmierci, czasu i przestrzeni. Cechą definiującą współczesną kulturę jest prędkość. Większa złożoność, indywidualizm oraz rewolucja wielokulturowości odcina tożsamość od tradycji i korzeni. Tendencje te odrywają kulturę śmierci od miejsca. W świecie zlaicyzowanej kultury, podporządkowanej nie sacrum tradycji a profanum nowoczesności, śmierć ulega trywializacji.

Początkiem badań geografów nad przestrzenią śmierci (deathspace) (RAGON 1983, TANAŚ 2006b), "przestrzenią umarlych” (deadspace) i „krajobrazem śmierci" (deathscape) (HOWETT 1977, KONG 1999, MADDRELL, SIDAWAY 2010, TREMLETT 2007) były prace z zakresu wcześniej opisanej amerykańskiej szkoły nekrogeografii (KNIFFEN 1967, WARNER 1959, NAKAGAWA 1987). 
Autor niniejszej pracy definiuje przestrzeń śmierci jako:

Fragment przestrzeni geograficznej, w której znajduje się zbiór przedmiotów będących nośnikiem znaczeń określających identyfikację kresu życia zarówno podmiotowego (człowieka, zwierzęcia, rośliny), jak i przedmiotowego (rzeczy, przestrzeni), identyfikowanego przez system znaków (symboli). Interpretacja przestrzeni śmierci zależy od czynników kulturowych, społecznych, ekonomicznych, geograficznych (przestrzennych) i czasu. Przestrzeń śmierci jest terminem ogólnym, ale nasyconym znaczeniami, w zależności od określającego je środowiska ludzkiego. Dopiero składowe tej przestrzeni (np. groby, cmentarze, pomniki, muzea) nadają charakter przestrzeni śmierci.

Ontologia egzystencjonalna M. HEIDEGGERA (2004) jest bardzo pomocna w zrozumieniu i analizowaniu przestrzeni śmierci. Czas i przestrzeń należy rozpatrywać z punku widzenia kwestii bycia człowieka. „Byt ku życiu” versus „byt ku śmierci” - tak rozumiana i interpretowana czasoprzestrzeń jest polem badań geografii śmierci, ponieważ w odróżnieniu od biologicznej śmierci ulega zmianom w czasie i przestrzeni.

Bycie człowieka w przestrzeni śmierci jest zarazem życiem tej przestrzeni w nas. Miejsce jako pewna treść duchowa nie ma bowiem innego sposobu istnienia, jak tylko poprzez jej rozumienie (JĘDRZEJCZYK 2008, s. 37). Cmentarz bez treści duchowych jest tylko „składowiskiem trupów”. Dzięki przypisaniu wartości duchowych cmentarzom, człowiek nadaje kolejny sens swej egzystencji (KOLBUSZEWSKI 1996).

Badania nad przestrzenią śmierci związane są z nurtem behawioralnym $\mathrm{w}$ geografii człowieka, mającym swoje początki w latach sześćdziesiątych ubiegłego wieku (SAUER 1986). Geografowie zajmują się w tych badaniach m.in. analizą postaw, podejmowania decyzji, znaczenia miejsca i krajobrazu. Studia nad wykorzystaniem przestrzeni śmierci w turystyce wpisują się w koncepcję behawioralnej geografii człowieka, gdzie zrozumienie rozkładu przestrzennego zjawiska antropogenicznego opiera się na wiedzy na temat decyzji i zachowań ludzkich mających wpływ na te zjawiska, a w mniejszym stopniu na rozmieszczeniu samych zjawisk (Golledge, Brown, Williamson 1972, za: WALMSLEY, LEWIS 1997, s. 15). Oznacza to, że do zrozumienia przestrzennych układów zjawisk (przestrzeni turystycznej) nie wystarczają prawa morfologiczne opisujące ich geometrię, a poznanie procesu wytwarzającego dany układ polega na badaniu decyzji podejmowanych przez ludzi (turystów) uczestniczących w tworzeniu tego układu.

Jedną z koncepcji opisujących przebieg procesu poznania środowiska sformułował J.R. GOLD (1980). Jego zdaniem informacja pochodząca ze środowiska przepuszczana jest przez filtr osobowości, kultury i poznania oraz tworzy reprezentacje poznawcze: wyobrażenia i schematy. Przedmiotem ba- 
dań geografii behawioralnej jest zatem człowiek wraz z jego interakcjami ze środowiskiem (WALMSLEY, LEWIS 1997, s. 30).

Badanie przestrzeni śmierci wymaga za każdym razem bardzo indywidualnego podejścia, zorientowanego na działanie pozostawiające człowiekowi swobodę $w$ interpretacji i ustaleniu znaczenia odwiedzanego środowiska (przestrzeni śmierci). Konstrukcja takiego modelu wymaga wyboru zmiennych wyjaśniających wykorzystujących nie tylko dane opisujące środowisko, ale również podmiot w nim działający (człowieka). Temu może służyć zastosowanie metod $\mathrm{i}$ analiz socjologicznych wykorzystywanych $\mathrm{w}$ badaniach nad geografią kultury. Badania mikroskalowe interakcji człowieka i środowiska (turysty i przestrzeni śmierci) winny uwzględniać środowisko jako źródło informacji, proces przetwarzania informacji oraz zachowanie człowieka wynikające $\mathrm{z}$ tych procesów. Niestety, przestrzeń śmierci może być inna dla każdego człowieka, co stanowi trudność w dochodzeniu do uogólnienia.

Ważnym problemem badawczym przestrzeni śmierci jest moralność przestrzeni i miejsca (DRIVER 1988), wynikająca z aspektu symbolicznego kultury związanej z kwestią wartości. Czy wykorzystywanie przestrzeni śmierci na potrzeby turystyki jest moralne? (STONE 2009a).

Jednym ze sposobów, opisujących obszary związane ze śmiercią w kontekście geograficznym jest doprowadzenie w koncepcji krajobrazu do stosowania terminu "krajobraz śmierci” (ang. deathscape). Głównym tematem dotychczasowych badań geograficznych nad przestrzenią śmierci była właśnie analiza krajobrazów śmierci, którą zajmowali się m.in. P. CLOKE, E. PAWSON (2008), K.V. HartiG, K.M. DunN (1998), L. Kong (1999), A. MAdDrelL, J.D. SiDAWAy (2010), E.K. TeATHER (2001), E.K. TEATHER, H.U. RII, E.H. KiM (2001), P. GROOTE (2012).

Krajobraz jest pojęciem bardzo zróżnicowanym, w geografii często wyrazem kultury i władzy i/lub relacji między naturą i społeczeństwem (ERIKSSON 2010). E.K. TEATHER (2001) używa terminu "deathscape" i „deadspace” pisząc o historycznym rozwoju cmentarzy na obszarach miejskich Hong Kongu, Seulu i Guangzhou oraz znaczeniu, jakie niosą one ze sobą dla ludzi tam mieszkających. Badania geograficzne nie tylko używają krajobrazu śmierci w celu wyrażenia ekspresji śmierci w pejzażu, poprzez palenie lub grzebanie zwłok, ale także aby dokonać opisu krajobrazów, w których ginęli ludzie i w których fakt ten został upamiętniony, np. przy drogach (HARTIG, DUNN 1998).

Krajobraz śmierci jest bardzo indywidualny. Jego postrzeganie, rozumienie uzależnione jest od indywidualnych doświadczen, wiedzy i postaw kulturowych. W turystyce rozumienie krajobrazu przez turystę jest determinowane jego pochodzeniem, wiedzą i pośrednio informacją przekazywaną 
przez otoczenie zewnętrzne (przewodnika, informacje turystyczną). We współczesnym świecie obserwować można nowe i unikatowe formy współżycia społecznego, w którym ogromne populacje są narażone na cierpienie i śmierć. Krajobrazy śmierci w tym kontekście pojawily się w Bośni, Czeczenii, Palestynie, Kolumbii, Sri Lance, Iraku (FARRER 2009). Również P.F. TREMLETT (2007) omawia inne wpływy niż lokalna kultura. Studiuje miasta Tajpej (Tajwan) i Manila (Filipiny) oraz bada krajobrazy śmierci jako „postmodernistyczny" krajobraz, wynikający z czynników politycznych i ekonomicznych.

Temat śmierci w badaniach geograficznych łączy się zazwyczaj z krajobrazem śmierci i analizowany jest przez pryzmat innych dyscyplin badających kultury i symbolikę widoczną w krajobrazie (ERRIKSON 2010). Studia geografów (HARTIG, DUNN 1998, TEATHER, RII, KIM 2001) wydają się sygnalizować wzrost zainteresowania krajobrazem śmierci, lokując go w geografii kultury.

Krajobraz śmierci został szczegółowo opisany w książce Deathscapes: Spaces for Death Mourning and Remembrance pod redakcją A. MADDRELL i J.D. SIDAWAY (2010). Opierając się na pracach autorów z różnych środowisk, w tym geografii, socjologii, sztuki, historii, psychologii, zdrowia, planowania i architektury, praca rozpatruje krajobraz śmierci z perspektywy relacji miejsca i śmierci. Deathscape (krajobraz śmierci) jako koncepcja krajobrazu kładzie nacisk na kreowanie miejsca przez formy kulturowe i ich wzajemne relacje $\mathrm{z}$ krajobrazami $\mathrm{w}$ nawiązaniu do zagadnień teoretycznych i praktycznych związanych ze śmiercią. Krajobraz ten obejmuje zarówno cmentarze, miejsca pamięci, miejsca śmierci, miejsca, w których znajduje się symbol śmierci, w tym sztuka. Analiza śmierci jest podejmowana przez wiele dyscyplin naukowych, jednak przestrzeń i miejsce są badane przede wszystkim przez geografów, przy współpracy z reprezentantami nauk społecznych i humanistycznych. Jednak krajobraz śmierci podlega również zmianom w czasie, tak jak śmierć jest ściśle skorelowana z czasem. $Z$ tego względu badania nad krajobrazem śmierci odwołują się do zmienności przestrzeni w czasie.

A. MADDRELL i J.D. SIDAWAY (2010) zdefiniowali deathscape jako krajobraz związany z umarłymi i żywymi, przesiąknięty znaczeniami i symboliką: przestrzeń pogrzebu, ostatecznego pochówki i pamięci. Mogą to być formalne przestrzenie publiczne, w których lokowane są pomniki, cmentarze i krematoria, ale także różne nieformalne przestrzenie, np. domowa lub związana z życiem i śmiercią zmarłego (znaczone w krajobrazie przez kapliczki, tablice pamiątkowe).

Śmierć jest rejestrowana $\mathrm{w}$ określonych przestrzeniach, np. szpitala, cmentarza, ceremonii pogrzebowej, jednak śmierć wpływa także i rozwija się $\mathrm{w}$ wielu innych miejscach $-\mathrm{w}$ domu, przestrzeni publicznej i miejscach kul- 
tu, miejscach wypadku, tragedii i przemocy. Krajobrazy śmierci są wielokrotnie bardzo mentalne, indywidualne, powiązane $\mathrm{z}$ osobistymi wspomnieniami i miejscami. Jednocześnie są publiczne, szczególnie w sferze upamiętnienia. Krajobraz śmierci można podzielić na trzy główne typy:

- miejsca śmierci,

- miejsca pochówku,

- miejsca pamięci.

Krajobraz jako kulturowa konstrukcja w szczególny sposób komponuje struktury, nadając im sens dla zewnętrznego świata. Konsekwencją tego podejścia jest nacisk na krajobraz jako konstrukcję i konieczność uznania roli "symbolicznych pejzaży", które „wytwarzają i podtrzymują znaczenia spoleczne" (COSGROVE, JACKSON 1987, s. 96).

Umarli służą też jako symbole porządku politycznego, wielokrotnie prowadząc "pośmiertne życie polityczne w służbie narodu” (VERDERY 1999). Przemieszczanie i miejsce pochówku wskazuje często na polityczne wykorzystanie zwłok (YOUNG, LIGHT 2013), co jest jednym ze sposobów na stałą obecność zmarłego w społeczeństwie (DAVIES 2002, VERDERY 1999). K. VERDERY (1999) twierdzi, że umarli są wielokrotnie wykorzystywani w procesie budowania tożsamości politycznej, poprzez kreowanie pośmiertnej pozycji zmarlego, jako męża stanu, autorytetu, którego postawy winno naśladować społeczeństwo. Służy temu instytucjonalizacja umarłego w postaci budowania pomników, mauzoleów, grobowców, stanowiących cel politycznych "pielgrzymek" i będących przedmiotem politycznego kultu. Przykłady mamy również w historii Polski, m.in. konflikt wokół miejsca pochówku Prezydenta Lecha Kaczyńskiego.

\subsubsection{NEKROGEOGRAFIA - IDEA GEOGRAFICZNYCH BADAŃ NEKROPOLII}

Zdefiniowana poniżej geografia śmierci obejmuje również badania przestrzeni umarłych (deadspace) i krajobrazów umarłych (deadscapes), które obejmują miejsca grzebalne. Nekropolie i ich lokalizacja w środowisku geograficznym były m.in. przedmiotem studiów z zakresu geografii religii (m.in. JACKOWSKI 2003, KLIMA 2012, SOŁJAN 2012) i badań krajobrazów kulturowych (SULIBORSKI 2005, TANAŚ 2008a).

Humanistyczną interpretacją przestrzeni kultury, której składnikiem są nekropolie, zajął się J. KACZMAREK (2002b). Według niego „nekropolie są przestrzenią kultury życia”, pozwalającą zachować pamięć o zmarłych w życiu społeczeństwa. Lokalizację $\mathrm{w}$ przestrzeni geograficznej symboli upamięt- 
niających śmierć określono nawet mianem tanatotopografii (MATYKOWSKI, DURA 2010).

Badania cmentarzy $\mathrm{w}$ naukach społecznych i humanistycznych można podzielić na dwie kategorie. Pierwsza, to architektoniczna analiza stylu i stylistycznej zmiany nagrobków lub grobowców; jest przede wszystkim wykorzystywana przez historyków, etnologów i archeologów (KOLBUSZEWSKI 1996). Druga jest bardziej czysto geograficzną analizą cmentarza będącego kategorią użytkowania gruntów i składowej krajobrazu. Nekropolia jest obiektem badań geografów od połowy lat sześćdziesiątych XX wieku. Zainteresowania cmentarzami przez geografów kultury mają odzwierciedlenie w nekrogeografii (KNIFFEN 1967, FRANCAVIGLIA 1971, HECKEL 1972, HEATHcote 1986, NAKAGAWA 1987, Kong 1999, TREMLETT 2007, HupKOVÁ 2008, JARVIS 2009). Począwszy od analizy morfologii nekropolii (KNIFFEN 1967), po badania nad ich znaczeniem w przestrzeni miejskiej (WIĘCEK 2005), w przestrzeni społeczno-kulturowej (KACZMAREK 2002b, SULIBORSKI 2005) czy w przestrzeni turystycznej (TANAŚ 2004), istotą badań geograficznych cmentarzy są ich funkcje, krajobraz i analizy przestrzenne.

Termin necrogeography (nekrogeografia) został użyty po raz pierwszy przez F. KNIFFENA (1967) do opisu krajobrazu cmentarzy w aspekcie przestrzennym i kulturowym, począwszy od form pochówku lub grobów, po złożoność krajobrazową terenów cmentarnych. Nekrogeografia, którą można nazwać również "geografią umarłych", zajmuje się analizą przestrzenną np. rozkładu grobów, pochodzenia i losów zmarłych, powiązań genealogicznych wykorzystując m.in. informacje odczytywane $z$ inskrypcji nagrobnych lub dostępne w księgach cmentarnych, takie jak: daty urodzin i śmierci, pochodzenie etniczne, płeć, wiek, migracje, zawód, status społeczny, religię $\mathrm{i}$ inne. $\mathrm{Z}$ tego względu jest powszechnie wykorzystywana w turystyce "genealogicznej" (sentymentalnej - ang. roots tourism, genealogy tourism). Nekrogeografia opiera się na symbolice i znakach pomocnych w odczytywaniu historii człowieka. Nekrogeografia to studia nad morfologią cmentarzy będących odbiciem realnego świata (FRANCAVIGLIA 1971, s. 501), których istotą są różnice morfologiczne i przestrzenne w obrębie cmentarzy, wskazujące na zróżnicowanie społeczne. Badania nad nią wykorzystują do opisu przestrzeni cmentarza takie dziedziny, jak: architektura, socjologia, psychologia, literatura, ekonomia i geografia kultury. R.V. FRANCAVIGLIA (1971) zwraca uwagę na to, że geograf kultury pracujący z literaturą z wymienionych dziedzin może znaleźć wiele interesujących aspektów nekropolii. Badany przez geografów emocjonalny (sacrum) i funkcjonalny (profanum) sens cmentarza, jako wspólnej przestrzeni żywych i umarłych, nawiązuje m.in. do koncepcji 
M. ELIADE (1996), który rozpatrywał wspólistnienie w przestrzeni sacrum i profanum.

Cmentarz jest analizowany jako krajobraz kulturowy określony indywidualnymi cechami i formami, takimi jak: grobowce i materiał wykorzystany do ich budowy, roślinność, ogrodzenie, infrastruktura techniczna, plan. Analiza ta jest podstawą do poszukiwania odpowiedzi na fundamentalne pytania, jakie stawia nekrogeografia. Jak cmentarz zmienia się $w$ czasie lub jak ewoluuje krajobraz cmentarza w określonym czasie, na określonym obszarze? Jak się zmieniają poszczególne części cmentarzy w określonym czasie? Jakie różnice występują między cmentarzami? (TANAŚ 2008b). Tak więc zasadniczym przedmiotem badań nekrogeografii są cmentarze, a w szczególności ich przestrzenna organizacja, materiały wykorzystane przy budowie, style grobowców i ich zróżnicowanie, kompozycje roślinne i terenowe składające się na krajobraz zwany deadscape.

Cmentarze są jednymi z najciekawszych krajobrazów kulturowych analizowanych przez geografów (MEYER 1993). Przegląd piśmiennictwa wskazuje, że większość publikacji koncentruje się na poszczególnych nekropoliach lub ich grupach na poziomie lokalnym (np. wieś, miasto) lub regionalnym. Badania F. KNIFFENA (1967) potwierdzają inni autorzy wskazując, że cmentarze odpowiadają regionalnym wzorcom kulturowym. Badania $\mathrm{w}$ ramach nekrogeografii utrzymują różnorodność i koncentrują się również na przestrzennych aspektach śmiertelności, dystrybucji i rozpowszechnianiu toponimów związanych ze śmiercią i pochówkiem, które były przedmiotem studiów również geografów kultury (ZELINSKY 1994).

Pomimo rosnącego zainteresowania nekropoliami w Polsce było do tej pory niewiele prób syntezy i interpretacji danych, jakie gromadzą cmentarze. Przede wszystkim popularne metody GIS nie są jeszcze szeroko stosowane w opisie nekropolii, tak jak w Stanach Zjednoczonych, gdzie wykorzystuje się je do dokładnej analizy przestrzennej, włącznie $\mathrm{z}$ analizami architektonicznymi wykorzystywanymi w pracach konserwatorskich (MATERO, PETERS 2003, JAŻDŻEWSKA 2010) (fot. 5).

Cyfrowe opracowania geodezyjne i kartograficzne mogą wspierać analizę baz danych wykorzystywanych w ochronie i zarządzaniu zabytkowymi cmentarzami. Projekty pomników, grobowców i nagrobków, motywy i napisy oraz nasadzenia roślinne ujawniają kulturowo uwarunkowane społeczne reakcje na śmierć. Dla wielu zabytkowych cmentarzy zmiany, jakie przyniósł ruch turystyczny $\mathrm{w}$ ich obrębie wywołują wiele problemów natury konserwatorskiej. Niewłaściwa rekonstrukcja nagrobków, komercjalizacja przestrzeni cmentarzy może wpływać na zatarcie pierwotnego charakteru nekropolii i bezpowrotnego zniszczenia ich historycznych walorów. Analiza 


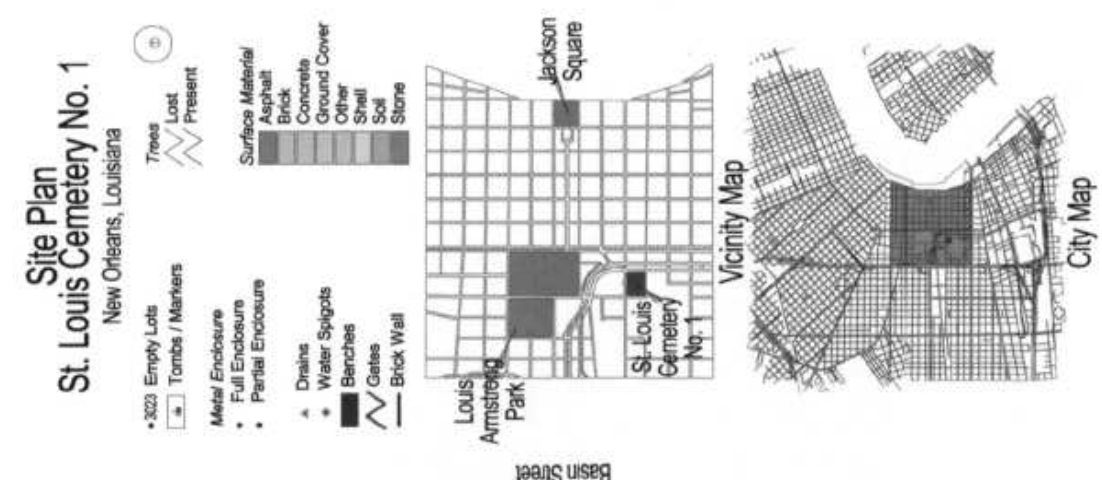

pans uiseg

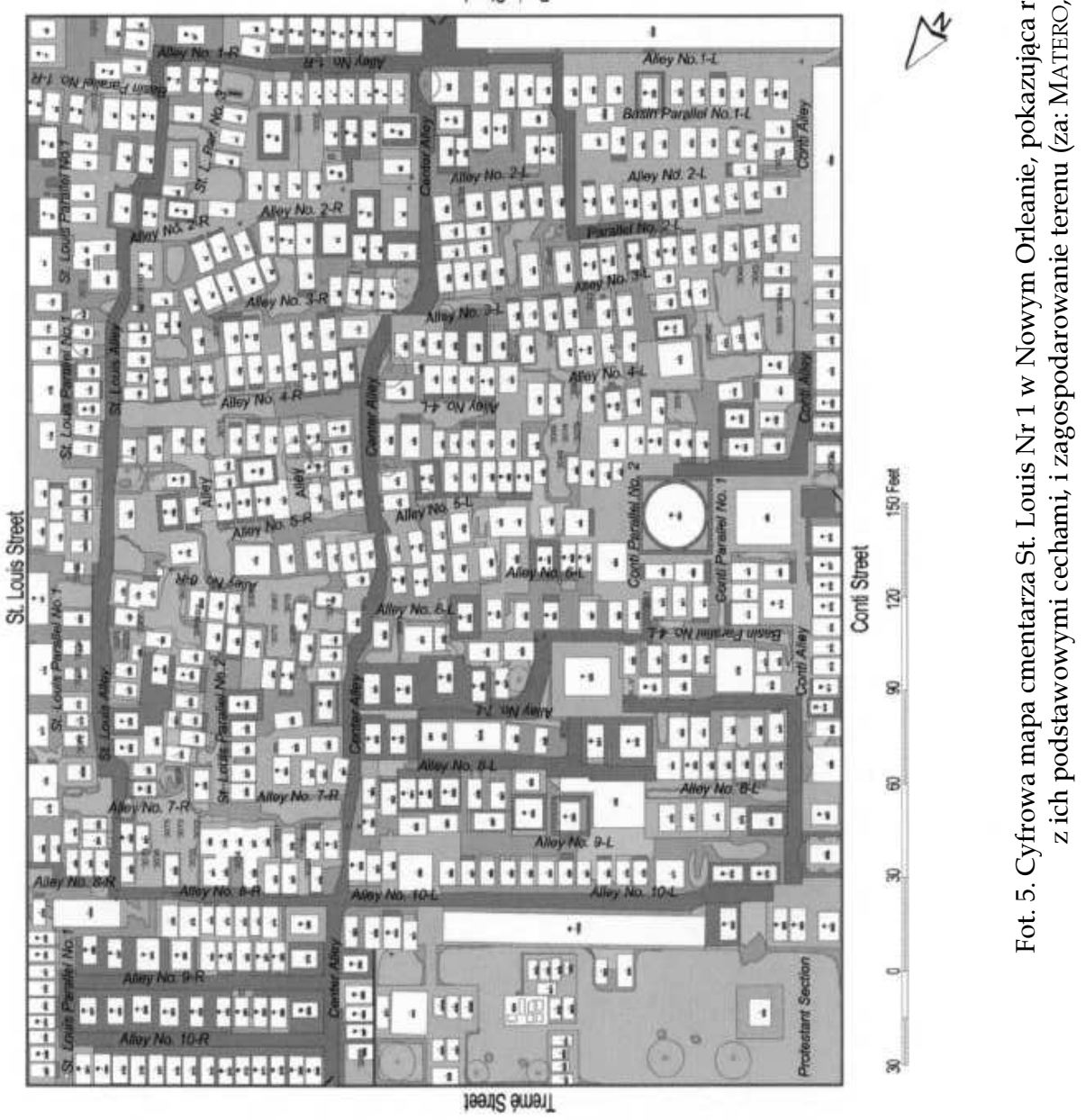


przestrzenna cmentarza wraz z korelacją danych jakościowych i ilościowych przy wykorzystaniu narzędzi GIS prowadzi do tworzenia bardzo dokładnych, czytelnych i nacechowanych wielowątkowością map nekropolii, które mogą być wykorzystane w zależności od określonych potrzeb, np. w poszukiwaniach mogil, genealogii, konserwacji, ochronie, turystyce i edukacji.

Historyczne cmentarze zazwyczaj mają znaczny zasób informacji, które po odpowiednim przetworzeniu można gromadzić za pomocą narzędzi cyfrowych do archiwizacji, analizy, zarządzania informacjami oraz sporządzania opracowań. Powiązanie tego typu programów z narzędziami GIS pozwalają na mapowanie i skomplikowane analizy przestrzenne nekropolii, zwiększając efektywność badań historycznych, archeologicznych czy społecznych. Służyć mogą również planowaniu zagospodarowania cmentarzy, szczególnie tych, w obrębie których występuje ciągła rotacja miejsc pochówku przy jednoczesnej ochronie konserwatorskiej (fot. 6).

Określenie tego, co stanowi właściwą ochronę i zarządzanie wyjątkową grupą dóbr kultury, jak cmentarze i inne obiekty przestrzeni śmierci, wymaga zrozumienia ich genezy, a także tego, w jaki sposób następowały zmiany zwyczajów i postaw wobec śmierci. Brak lub niedostateczna ewidencja konserwatorska polskich cmentarzy i nagrobków wynikają z trudności $\mathrm{w}$ archiwizowaniu danych opisowych i kontrolowaniu aktualnego stanu wykorzystania miejsc grzebalnych. Przykładem może być łódzki Stary Cmentarz, którego zabytkowa część nie doczekała się rzetelnej i wyczerpującej ewidencji, konsekwencją czego jest dewastacja nagrobków i ponowne zagospodarowanie miejsc grobowych na pochówek.

Niedostateczny stąpień wykorzystania narzędzi GIS $\mathrm{w}$ analizie przestrzeni cmentarzy i praktycznego wykorzystania nekrogeografii, która w Stanach Zjednoczonych Ameryki jest stosunkowo popularna, świadczy być może o słabości współczesnych geografów, niechętnie podejmujących badania nad przestrzennymi aspektami dziedzin takich, jak np. antropologia, folklor, historia architektury. Dlatego autor postuluje w dalszej części pracy o podjęcie badań geograficznych, przedmiotem których byłyby polskie nekropolie, ponieważ zarówno metodologia badań, jak i wyniki mogą być użyteczne $\mathrm{w}$ interpretacji i ochronie krajobrazu kulturowego.

L. KONG (1999), która dokonała przeglądu badań nekrogeograficznych od 1990 roku, zwraca uwagę na to, że odwołują się one wielokrotnie do innych dyscyplin geografii. W szczególności badania pokazują znaczenie krajobrazów śmierci (deathscapes) w systemach społecznych zróżnicowanych pod względem rasy, klasy, płci, narodu i charakteru. Jednak ze względu na silne powiązania $\mathrm{z}$ innymi obszarami badań geograficznych nekrogeografia sama w sobie nie może być koncepcyjnie uznaną dziedziną geografii. Istnieje 
zatem potrzeba włączenia jej do dyskusji w różnych dyscyplinach i koncepcjach geografii, m.in. w geografii kultury, człowieka, czasu.

Termin „nekrogeografia” jest również wykorzystywany w badaniach podejmujących problematykę przestrzennego zróżnicowania śmierci w ramach geografii śmierci (ERIKSSON 2010).

Oprócz celów i ich praktycznego znaczenia kulturowego badania nekrogeograficzne przynoszą wiele ważnych informacji. Inskrypcje nagrobne określają datę narodzin i śmierci, pochodzenie etniczne, płeć, długość życia, migracje, zawód, status społeczny, wyznanie i inne informacje demograficzne. Groby, grobowce, epitafia mogą stanowić swego rodzaju laboratorium
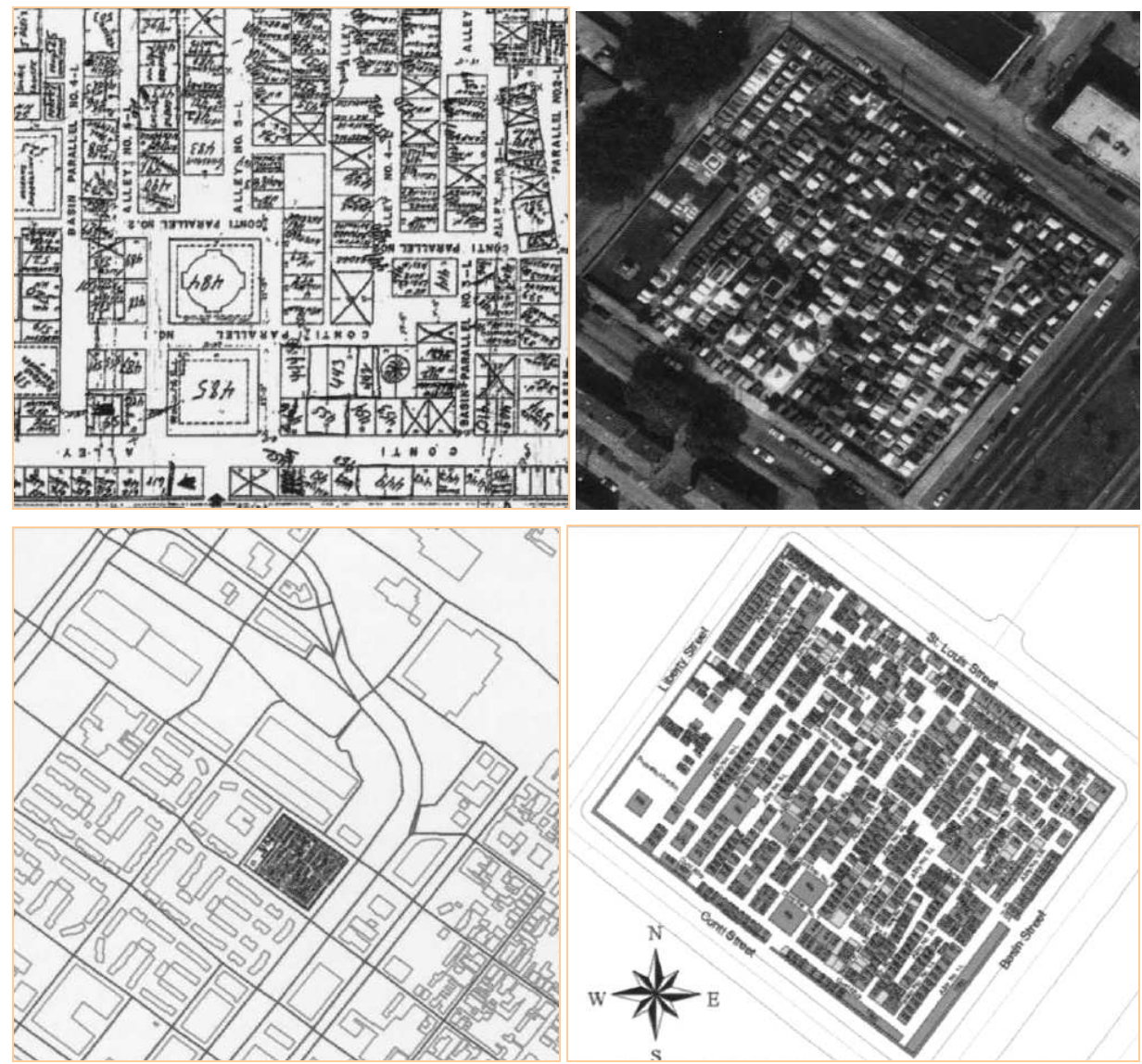

Fot. 6. Przykład wykorzystania narzędzi GIS w opracowaniu mapy lokalizacji grobów na cmentarzu St. Louis Nr 1 w Nowym Orleanie (USA);

zdjęcie przedstawia odręczny plan cmentarza, zdjęcie lotnicze, lokalizację cmentarza na planie miasta oraz cyfrowe opracowanie rozmieszczenia grobów wraz ich charakterystyką i ewidencją GPS (MATERO, PETERS 2003) 
dla naukowców, konserwatorów, architektów i rzeźbiarzy badających wytrzymałość stosowanych materiałów, zwłaszcza kamienia (piaskowca, marmuru, granitu) i metalu, które są poddawane surowym warunkom atmosferycznym przez setki lat (MATERO, PETERS 2003).

Style cmentarzy są urozmaicone na całym świecie. W większości tradycyjnych i współczesnych kultur przestrzeń umarłych jest wyraźnie oddzielona od przestrzeni żywych. J.R. PITTE (2004) zwraca uwagę na geograficzne zróżnicowanie cmentarzy, będących nagromadzeniem materialnych wartości kultury śmierci, stanowiące podstawową problematykę badawczą nekrogeografii. Podane poniżej przykłady zróżnicowania krajobrazowego cmentarzy wskazują na zainteresowanie nekrogeografii krajobrazem nekropolii. Cmentarze, które wyróżniają się oryginalnością stanowią jednocześnie walor wykorzystywany w turystyce (fot. 7).

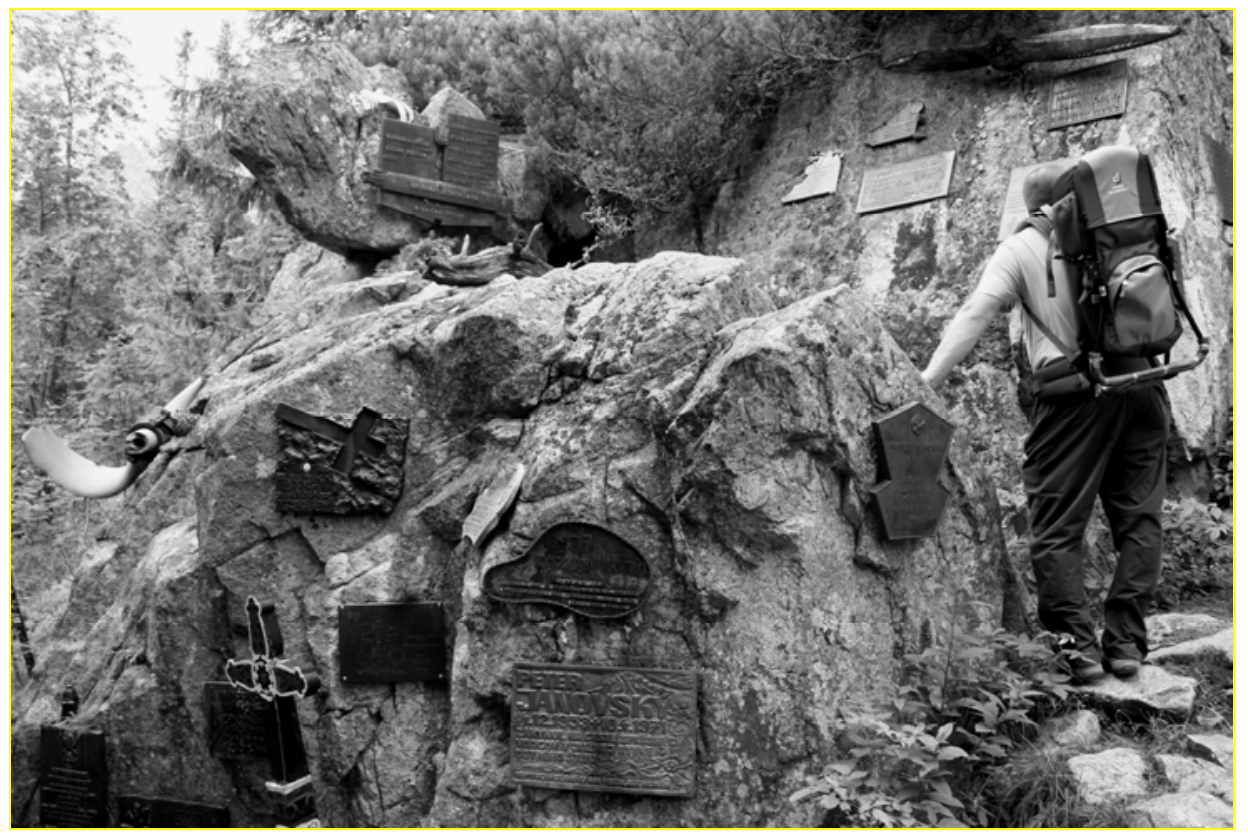

Fot. 7. Tatrzański Cmentarz Symboliczny - Słowacja (autor: S. Tanaś)

Już jaskinie kumulowały praktyki pogrzebowe z powodu ich tajemniczości i niedostępności. Przykłady można znaleźć w Azji Południowo-Wschodniej, ale także w prekolonialnych cywilizacjach Ameryki. W krajach germańskich, z głęboko zakorzenionym mitem pierwotnego lasu i dziewiczej przyrody, cmentarze były często zorganizowane w lesie. W całej Europie 
Północnej i Ameryce Północnej cmentarze są dość rozległe, a groby wtopione są dyskretnie w zieleń. W Japonii dobrze utrzymane cmentarze są zazwyczaj położone wokół buddyjskich świątyń, które, z wyjątkiem dużych miast, są budowane na peryferiach miast. W Korei natomiast cmentarze są przestrzenią bardzo rodzinną, groby są indywidualne, w postaci tumulusów porośniętych trawą symbolizujących łono matki, otoczone pionowymi fallicznymi stelami. Większość cywilizacji grzebie zmarłych poza miastem i wsią. Zasadą jest oddzielenie przestrzeni żywych od umarłych, ale także przyświecają tej idei względy higieniczne i planistyczne, niepozwalające na organizowanie cmentarzy w mieście. Odległość również sprzyja organizacji kultu zmarłego. Cmentarz położony na Górze Oliwnej w Jerozolimie naprzeciwko Wzgórza Świątynnego gromadzi groby już od trzech tysięcy lat. Wielu Izraelczyków i Żydów z diaspory chce być pochowana w tym błogosławionym miejscu. Chrześcijanie, chociaż religijnie bardziej przywiązani do ducha niż ciała, jako pierwsi wprowadzili zmarłych do miasta. Prawdopodobnie dlatego, że narodziny ich religii były ściśle powiązane z kultem męczenników i żywili nadzieję na błogosławieństwo zmarłego poprzez bliskość jego miejsca spoczyn$\mathrm{ku} \mathrm{z}$ najświętszym sakramentem przechowywanym $\mathrm{w}$ prezbiterium świątyni. Na świecie odnajdziemy również cmentarze symboliczne gromadzące mogiły osób, których ciała nie zostały odnalezione lub z określonych powodów nie mogły być sprowadzone i złożone $\mathrm{w}$ grobach rodzinnych.

Reasumując powyższe należy podkreślić, że ocena i planowanie $\mathrm{w}$ zakresie ochrony zabytkowych cmentarzy oraz ich krajobrazów może być znacznie utrudniona, szczególnie $\mathrm{w}$ miastach, ze względu na potrzebę racjonalnego gospodarowania przestrzenią grzebalną. Nekrogeografia wraz z zastosowaniem kartograficznych narzędzi analiz przestrzennych może być pomocna w efektywnym gospodarowaniu przestrzenią nekropolii, przy jednoczesnym zachowaniu ich zabytkowego układu i charakteru. Nekrogeografia analizuje również krajobraz cmentarzy $\mathrm{i}$ innych przestrzeni śmierci z perspektywy geografii kultury, zagospodarowania przestrzennego i pozostałych dyscyplin, których przedmiotem badań są przestrzenie śmierci, w szczególności cmentarze.

\subsubsection{KONCEPCJA GEOGRAFII ŚMIERCI}

Geografia śmierci obejmować winna identyfikację ontologii śmierci w ujęciu zróżnicowania przestrzennego i kulturowego. W każdym środowisku społecznym można bowiem wyróżnić wyraźne cechy społeczne, takie jak mity, przesądy, praktyki religijne, które wpływają na budowanie modelu powszechnie obowiązującego sposobu myślenia w obrębie tejże kultury. Poczu- 
cie wspólnoty dla określonego społeczeństwa, które można dostrzec w materialnych wytworach kulturowych, jest tym, co można określić krajobrazem intelektualnym (KENZER 1985), którego interpretacja jest subiektywna (TUAN 1978).

Zróżnicowanie geograficzne przestrzeni śmierci może dotyczyć:

- aspektów medycznych: chorób, tempa starzenia się, eutanazji, handlu narządami;

- aspektów kulturowych: form żałoby, pochówku i pamięci, systemu wierzeń, mediatyzacji śmierci;

- aspektów politycznych: ataków terrorystycznych, wojen, ludobójstwa;

- aspektów środowiskowych: środowisko życia człowieka.

Liczne na świecie publikacje, które zaliczyć można do prac nad geografią śmierci, nie są niczym nowym. Można do nich zaliczyć prace z kręgu geografii kultury, badającej przestrzenne rozmieszczenie śmierci ludzi (PITTE 2004). W Stanach Zjednoczonych prowadzone są badania nad geograficznymi aspektami kary śmierci, m.in. nad zależnościami pomiędzy rasą, pochodzeniem, miejscem zamieszkania, przestępczością a miejscem wykonania kary śmierci (COHEN, SMITH 2010). Stosunek Kościoła do umieralności i następstw społeczno-religijnych związanych $\mathrm{z}$ nią był przedmiotem badań w Szwecji (GRASSMAN, WHITAKER 2007), natomiast skutki działalności organów państwa i związane z tym przestrzenne aspekty zabójstw prowadzili J.C. VARGAS i A.J. AMPARO (2010). Tych kilka przykładów potwierdza działalność badawczą prowadzoną przez geografów w zakresie przestrzennych aspektów śmierci, odwołujących się do różnych problemów specjalistycznych. Najczęściej geografia śmierci obejmuje zagadnienia związane z umieralnością ludzi i wpływem postępu medycznego na wydłużenie życia lub z czynnikami decydującymi o jego skróceniu. Czynniki te zaliczymy nie tylko do grupy medycznych, ale również cywilizacyjnych. Są bowiem regiony na świecie, gdzie długość życia jest skrócona ze względu na działania wojenne (czynnik polityczny), niedobory żywności i wody, nieprzestrzeganie podstawowych norm higieny, rozwój chorób cywilizacyjnych, takich jak HIV, otyłość, cukrzyca itp. W oparciu o statystyki konstruowane są mapy umieralności według przyczyn zgonu w ramach geografii medycznej w Stanach Zjednoczonych, Wielkiej Brytani, Holandii (MURRAY 1962, 1967, FOSTER, EDGELL, red. 1992, HOWE 1968).

Zróżnicowanie przestrzenne obejmuje również rytualizację śmierci (np. postępowanie ze zwłokami, obrzędy pogrzebowe, żałoba, formy pochówku), wyraźnie skorelowaną z geografią religii. Jednak sposób postępowania ze zwłokami może być zdeterminowany nie tyle religią i wierzeniami, co skutkami postępu cywilizacyjnego (np. kremacja w świecie Zachodu wymuszona 
jest brakiem miejsc grzebalnych bądź laicyzacją życia i rozwojem przemysłu pogrzebowego, odrzucającego tradycyjny pochówek, a przyjmującego pragmatyczny sposób postępowania ze zwłokami).

Sposoby umierania, rytualizacja śmierci, upamiętnienie zmarlych są przedmiotami badań historyków, etnologów, antropologów czy architektów. Geografowie zajmowali się również badaniami nad przestrzennym zróżnicowaniem kulturowym postępowania wobec zmarlych, zwracając uwagę na różnorodność form pochówku (JACKOWSKI 2003).

Jednym z tematów podejmowanych przez geografię śmierci jest geografia miejsc śmierci i sposobów umierania. Umieranie może odbywać się w różnych warunkach - w spokojnym otoczeniu najbliższej rodziny, na polu walki, w gwałtowny i brutalny sposób. Ludzie umierają cierpiąc lub łagodząc cierpienie $\mathrm{w}$ szpitalu, ale także gwałtownie - $\mathrm{w}$ wyniku nagłego zdarzenia. Śmierć może nastąpić z głodu, pragnienia, w wyniku chorób. Umierać można cierpiąc tortury i będąc poniżanym. Geografię śmierci również można uznać za dział geografii kultury obejmujący badania nad przestrzennymi aspektami śmierci, w szczególności:

- aktem śmierci (miejsca nagłej śmierci, zbrodni, ludobójstwa itd.);

- kulturą śmierci i kulturowym dziedzictwem śmierci (np. rytuał, metody pochówku, organizacja cmentarzy);

- realną i symboliczną przestrzenią śmierci.

Rozpatrując zagadnienia geografii śmierci należy ulokować ją w naukach geograficznych, w szczególności związanych z geografią społeczną (rys. 17).

Analizy geograficzne aktów śmierci, przyczyn zgonów i migracji zmarłych, w tym analiza przestrzennego zróżnicowania organizacji pogrzebów (rytuałów i obrzędów pogrzebowych) podejmowane są przez wielu badaczy na świecie (DAVIES 2002), również w zakresie organizacji przestrzeni śmierci (MADDRELL, SIDAWAY 2010, TEATHER 2001), a także praktyk upamiętniających, mających wpływ na politykę pamięci, zwłaszcza w zakresie budowy tożsamości narodowej (FOREST, JOHNSON 2002).

Ważnym zagadnieniem poddawanym badaniu $\mathrm{w}$ geografii śmierci jest miejsce, rozpatrywane wieloaspektowo. Miejsce jest częścią podległej ludziom jednostkom przestrzeni, którą poznają i w ramach której działają (LISOWSKI 2005). Miejsce jako stacja w biografii jednostek zostało określone wyraźnie w geografii czasu T. Hägerstranda. Prace geograficzne i socjologiczne odwołujące się do geografii czasu ukazują najczęściej możliwości tkwiące w człowieku, jako kreatorze swojego miejsca, i wyjaśniają funkcjonowanie jednostki $\mathrm{w}$ miejscu $\mathrm{w}$ ramach określonych społeczności oraz zwrotne oddziaływanie przestrzeni miejsca na zachowania i wyobrażenia człowieka (KACZMAREK 2005, THRIFT 1983). 


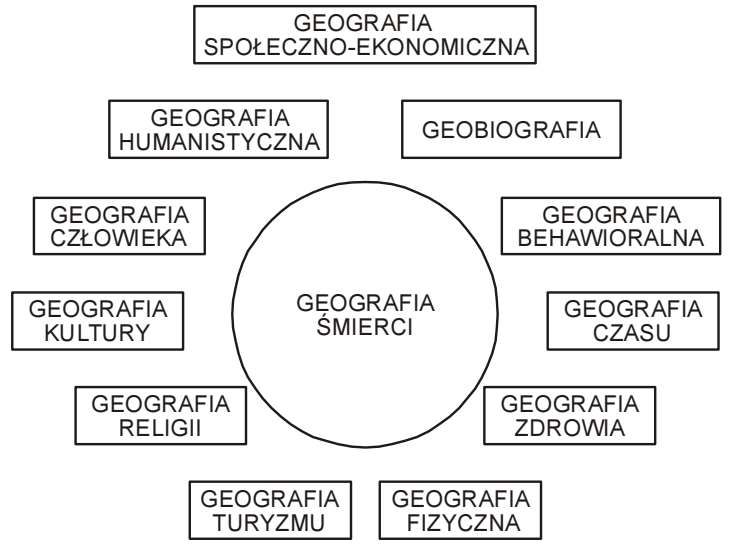

Rys. 17. Miejsce geografii śmierci w koncepcjach geograficznych Źródło: opracowanie własne

Śmierć określa miejsce bytu-niebytu człowieka w czasie i przestrzeni. $\mathrm{Z}$ tego względu geografię śmierci należałoby ściśle wiązać z geografią czasu. Śmierć człowieka pozostaje bowiem w pamięci żyjących w ograniczony sposób. Pamięć jest z kolei determinowana wieloma czynnikami społecznymi i kulturowymi. Utrwalanie $\mathrm{w}$ pamięci zdarzeń, również pamięć o śmierci, wzbudza w jednostce emocje pozytywne i negatywne. Miejsce w kategorii humanistycznej jest zatem pewną kategorią świadomości, której zmienność i wielorakość wyobrażeniowa zależy od postawy człowieka wobec świata i jego doświadczeń. Miejsce powstaje jako wyraz przeżyć oraz świadomości jednostkowej i społecznej. Jest niepowtarzalną przestrzenią istniejącą w samych ludziach, a zarazem na zewnątrz nich, poprzez przypisywanie określonym elementom znaczeń (WójcIK 2008, s. 52).

Miejsca śmierci spełniają wymienione warunki indywidualnej przestrzeni wyobrażeń. Trwanie miejsca (np. miejsca pamięci) daje poczucie stabilności, identyfikacji i tożsamości. Trwałość nadaje więc miejscu społeczną tożsamość. Miejsca nie można zatem oderwać od trwałości czasu (KACZMAREK 2005). Podobnie jak śmierć, miejsce jest kategorią egzystencjonalną, a koncepcja miejsca jest nierozerwalnie związana $\mathrm{z}$ humanistyczną koncepcją geografii (JĘDRZEJCZYK 2001).

Geografia śmierci obejmuje problematykę badań nad przestrzennym rozmieszczeniem dziedzictwa śmierci w aspekcie:

- kultury materialnej i niematerialnej;

- medycyny - śmiertelność człowieka, choroby, głód;

- wojny, terroryzmu;

- zabójstw; 
- katastrof, wypadków;

- śmierci krajobrazu (antropogenicznego i przyrodniczego).

Geografia śmierci może zatem zostać określona jako przestrzenne rozmieszczenie zjawisk związanych ze śmiercią podmiotową i przedmiotową, determinowane czynnikami kulturowymi, społecznymi, religijnymi i przyrodniczymi.

Istotnym zagadnieniem, z perspektywy problemu badawczego, jakim zajmuje się geografia śmierci, jest określenie przedmiotu badań, który można podzielić ze względu na kryterium aktu śmierci i artefaktu śmierci:

A. Przedmiotem badań aktu śmierci, jego formy, instytucjonalizacji, lokalizacji będą:

1) zgony:
a) naturalne,
b) chorobowe;

2) zdarzenia losowe:
a) wypadki komunikacyjne,
b) inne wypadki,
c) naturalne kataklizmy;

3) morderstwa;

4) akty zbrojne:
a) wojny,
b) ludobójstwo,
c) zamachy terrorystyczne,
d) inne zamachy;

5) prawo:
a) kara śmierci,
b) tortury,
c) rytuał.

B. Przedmiotem badań, którym są artefakty związane ze śmiercią będą:

1) miejsca kultu, w tym miejsca gromadzące ludzkie szczątki:
a) świątynie,
b) cmentarze,
c) groby,
d) ossuaria,
e) krypty,
f) katakumby;

2) miejsca pamięci:
a) pomniki,
b) mauzolea,
c) tablice; 
3) zbiory dokumentujące:
a) muzea,
b) wystawy,
c) izby pamięci;

4) rytualizacja:
a) obrzędy,
b) tradycje,
c) zachowania;

5) miejsca rozrywkowe:
a) "fabryki mrocznej zabawy”,
b) lunaparki,
c) muzea;

6) inne:
a) miejsca katastrof,
b) miejsca indywidualnej i masowej śmierci,
c) "przestrzenie wymarłe” - świadczące o minionym życiu.

Geografia śmierci, tak jak geografia humanistyczna, próbuje uchwycić elementarną strukturę relacji zachodzących między ludzką świadomością a środowiskiem geograficznym. Celem geografii śmierci jest zatem zrozumienie przestrzennego zróżnicowania kultury śmierci jako systemu znaków, wartości, działań i ich skutków oraz wpływu kultury śmierci na przestrzeń geograficzną i samego człowieka.

O komplementarności geografii i etnologii pisali M.Z. PULIANOWA i Z. KŁODNICKI (2005). Metoda przestrzennego ujmowania zjawisk w etnografii polega na interpretacji elementów kulturowych na określonym obszarze, przy uwzględnieniu czynników geograficznych i historycznych.

Śmierć jako podróż oraz świat po śmierci istnieje w wielu kulturach. Można z pewnością wręcz mówić o nieziemskiej geografii świata śmierci, która przenika do świata żywych w postaci wyobrażeń w literaturze, malarstwie i rzeźbie. Praktycznie każda religia ma swój świat pozagrobowy (KLIMA 2012). Grecy przedstawiali rzekę Styks i Acheron oraz królestwo Hadesu. Greckie mity ukazywały wizję Hesperyd i Wysp Szczęśliwych oraz Pól Elizejskich. Wikongowie mieli swój Niflheim - królestwo zmarłych. Aztekowie ziemię zwaną Mictlan, do której aby dotrzeć dusza musiała pokonać wysokie góry i rwące rzeki, wspinając się po ścianach zbudowanych $\mathrm{z}$ obsydianu (KERRIGAN 2009, s. 23). Egipcjanie wierzyli w "Ziemię Trzciny” rządzoną przez Ozyrysa, na wzór faraona rządzącego Egiptem.

Mity i folklor obfitują w dramatyczne opowieści, w których mowa jest o podróżach do baśniowych krain, gdzieś za oceanem lub na końcu świata. Te mityczne krainy symbolizują najczęściej królestwo umarłych. Nie sposób 
jednak odtworzyć początki lub historię "funeralnych geografii", odnoszących się do postrzegania świata umarlych (ELIADE 1992, s. 47). Religie różnie umieszczają cel duszy zmarłego. Są to drogi prowadzące przez rzekę, most, morze, drzewo, urwisko, podczas ostatecznej wędrówki pojawia się łódź, strażnik, granica. Od lat dwudziestych $X X$ wieku w literaturze zaistniała identyfikacja geografii śmierci w powieściach, teatrze i poezji (ELIADE 1992, s. 51).

Badania prowadzone $w$ ramach geografii śmierci implikują konieczność posługiwania się metodami badań geografii człowieka i geografii humanistycznej, czerpiąc wzorce z fenomenologii, hermeneutyki, semiologii i antropologii. Śmierć ma wpływ na wszystkie aspekty życia, dotyka naszych emocji i wpływa na naszą tożsamość. Jest ważnym nowym obszarem badań w wielu dyscyplinach (DAVIS, PARK 2012). Autor wyraża nadzieję, że nakreślone ramy koncepcyjne geografii śmierci zachęcą do prowadzenia badań przestrzennych (geograficznych) nad wieloaspektowymi zagadnieniami związanymi ze śmiercią i jej następstwami, mającymi swoje odzwierciedlenie $\mathrm{w}$ przestrzeni geograficznej. 


\section{CZŁOWIEK W PRZESTRZENI TANATOTURYSTYKI}

Turystyka, która jest przede wszystkim zjawiskiem przestrzennym, pozostającym w głównym nurcie badawczym autora, jest również zjawiskiem społecznym (PRZECŁAWSKI 1996, WINIARSKI, ZDEBSKI 2008), kulturowym i ekonomicznym. Jak już wielokrotnie podkreślano, przestrzeń śmierci, podobnie jak przestrzeń turystyczna jest wytworem działalności człowieka, zróżnicowanym geograficznie i zmiennym $\mathrm{w}$ czasie. Zachowania ludzkie podlegają ciągłym zmianom determinowanym wieloma czynnikami, w tym geograficznymi, przyrodniczymi i kulturowymi. Autor podejmując próbę analizy tanatoturystyki posiłkuje się zmiennością pokoleniową, którą odnosi do zachowań turystycznych i w której upatruje źródła zmian w turystycznym postrzeganiu przestrzeni śmierci. Z racji geograficznego charakteru pracy autor ograniczył charakterystykę badań prowadzonych nad kulturowymi i socjologicznymi aspektami turystyki, a następnie dokonał próby uporządkowania zagadnień związanych $\mathrm{z}$ kulturową przestrzenią turystyczną, $\mathrm{w}$ ramach której można wyodrębnić przestrzeń tanatoturystyki.

Zmiany zachodzące $\mathrm{w}$ postawach turystycznych człowieka można opisać za pomocą studium dystansu międzypokoleniowego, jaki przedstawiła M. MEAD (1978) w zbiorze szkiców pt. Kultura i tożsamość. Jej spostrzeżenia i analizy pozwalają zrozumieć mechanizmy i prawidłowości funkcjonowania międzygeneracyjnego przekazu kulturowego, które w zachodnich społeczeństwach doprowadziło do kryzysu społecznego i wychowawczego. Kryzys dotknął również szeroko rozumianych podstaw ideologicznych i funkcji społecznych turystyki, widocznych m.in. w marginalizacji krajoznawstwa. Postrzeganie i definiowanie atrakcyjności turystycznej jest zmienne. To co dla współczesnego turysty z Europy Zachodniej jest atrakcyjne, dla turysty z innego obszaru kulturowego może być interpretowane na odwrót. Tanatoturystyka jest bardzo wyrazistym przykładem zmienności $\mathrm{w}$ rozumieniu atrakcyjności turystycznej, wywołując dyskusję nad granicami etycznymi i moralnymi wykorzystywania w turystyce tworów życia społeczno-kulturowego. 
Ze względu na różnorodność środowisk, w których przebiega socjalizacja młodego pokolenia oraz sposobów, w jaki dokonuje się przekaz kultury między pokoleniami M. MEAD (1978) wyodrębniła trzy typy kultur: postfiguratywną (tradycyjną, konserwatywną), kofiguratywną (nowoczesną, tolerancyjną) i prefiguratywną (ponowoczesną, liberalną).

Model M. MEAD (1978) wskazuje na skutki różnic pokoleniowych w kultywowaniu tradycji oraz respektowaniu ustalonych norm społecznych. Różnice są szczególnie widoczne wśród dojrzałych i ukształtowanych kulturowo grup społecznych, w których nowości zazwyczaj uznawane są przez młode i średnie pokolenia, z trudem tolerowane przez pokolenia starsze. Nowe postawy kulturowe szczególnie łatwo akceptują grupy dopiero odnajdujące swoje miejsce w systemie społecznym. Do nich zaliczyć można młode pokolenia odrzucające tradycyjne sposoby postrzegania porządku świata, naśladujące i przyjmujące normy kulturowe innych grup, tolerujące odmienność i akceptujące postawy, nieakceptowane przez pokolenia konserwatywne.

Badania M. MEAD (1978) posłużyły autorowi do stworzenia koncepcji turystycznego dystansu międzypokoleniowego, m.in. w odniesieniu do atrakcyjności turystycznej, turystycznej interpretacji dziedzictwa kulturowego, wychowawczych funkcji turystyki i przemian zachodzących w rozumieniu indywidualnej przestrzeni turystycznej. Wcześniej należy zastanowić się nad związkami kultury z turystyką, rolą, jaką odgrywa kultura w turystyce, oraz nad kulturową różnorodnością interpretacji walorów turystycznych.

\subsection{TURYSTYKA KULTUROWA}

Jednym z zagadnień opisujących zainteresowanie turystyczne przestrzenią śmierci jest kontakt międzykulturowy, który można określić jako interakcyjne zetknięcie się kultur. Kontakt międzykulturowy determinowany jest ruchem ludności, w tym ruchem turystycznym.

A. KOWALCZYK $(2008$, s. 13) turystykę kulturową definiuje jako „zespół zachowań turystów związanych $\mathrm{z}$ ich autentycznym zainteresowaniem dziedzictwem kulturowym oraz ich uczestnictwem w szeroko rozumianym współczesnym życiu kulturalnym".

Zdaniem autora, turystykę kulturową wyróżnia przedmiot zainteresowania turystycznego, który wywołuje potrzebę przemieszczenia się w przestrzeni geograficznej. Wobec tego turystyką kulturową będzie zespół zachowań turystów, których przedmiotem zainteresowania jest geograficznie zróżnicowana kultura i jej dziedzictwo. 
K. PODEMSKI (2004) w socjologicznym opisie podróży turystycznych zwraca uwagę na takie zagadnienia, jak: zmienność kulturowa, konflikt kulturowy, zderzenie kultur, akulturacja, dyfuzja kulturowa, szok kulturowy, które stosunkowo rzadko używane są $\mathrm{w}$ badaniach geograficznych podróży turystycznych. $\mathrm{W}$ odniesieniu do tanatoturystyki mają one znaczenie $\mathrm{w}$ analizie procesów wyjaśniających podróże kulturowe do przestrzeni śmierci.

Kontakt z nieznaną wcześniej przestrzenią kulturową prowadzić może do szoku kulturowego, definiowanego przez Lexicon zur Sociologie (1975; za: PODEMSKI 2004, s. 35) jako „[...] bardziej lub mniej nagłe, budzące lęk pojawienie się zupełnie odmiennej rzeczywistości właściwej innej kulturze przy bezpośrednim kontakcie z kulturą obcą. Szok jest ważnym wydarzeniem egzystencjonalnym, który umożliwia zrozumienie obcych kultur, a przez to i własnej kultury."

Turystyka kulturowa odgrywa kulturotwórczą rolę w procesie poznawania kultur. Odbywa się to m.in. poprzez (PRZECŁAWSKI 1996, GOLKA 2008):

- wprowadzanie elementów poznawanej kultury do szerszej świadomości społecznej;

- odkrywanie kultur poprzez przekraczanie granic;

- identyfikację elementów kultury;

- pobudzanie mechanizmów jej obiegu;

- rozbudzanie potrzeb kulturalnych;

- interpretację kultury;

- poznanie i wzbogacenie wartości kultury.

Poszczególne elementy kultury wytwarzane są początkowo w wyizolowanych, niewielkich zbiorowościach społecznych. Ich upowszechnieniu sprzyja opis, dokumentacja, informacja, co ma miejsce $\mathrm{w}$ działalności poznawczo-turystycznej człowieka. Niestety, w wyniku upowszechniania określonych elementów kultury w ramach działalności turystycznej dochodzi wielokrotnie do oderwania ich od pierwotnego kontekstu. Turysta docierający do przestrzeni śmierci niejednokrotnie może ją źle zrozumieć, zinterpretować na opak i wybrać tylko wyróżniające się elementy sensacyjne i szokujące, utrwalić je i przenieść w oderwaniu od rzeczywistego celu, jaki spełniają. Wytwory kultury śmierci mogą być inaczej interpretowane przez turystę, niż zakłada to pierwotna ideologia. Przykładem jest utrwalanie za pomocą filmu lub fotografii archaicznych obrzędów rytualnych związanych z tradycją pogrzebu, np. sposobu traktowania ciała zmarłego, i prezentowanie obrazów w kontekście sensacyjności podróży, bez wcześniejszego przygotowania odbiorcy do ich interpretacji.

Podróż kulturowa jest odkrywaniem kultur poprzez przekraczanie granic. W wyniku globalizacji współczesny turysta poznaje nieznane elementy 
kultury, które do niedawna były poza jego zasięgiem, poza nieprzekraczalną granicą polityczną, kulturową, religijną. Obecnie obieg informacji i działalność poznawcza nie ma właściwie granic. Turystyka poznawcza w swoisty sposób neutralizuje odmienność kultur, powoduje, że nawet najbardziej egzotyczne formy kulturowe uznajemy za własne. Jednak, jak wspomniano wcześniej, towarzyszy temu procesowi bardzo często zbyt duże uproszczenie obrazu (GOLKA 2008, s. 11). Przykładami mogą być krypty klasztorne otwierane dla turystów, rytualne ciałopalenie w Indiach czy popkulturowe święto Halloween (fot. 8).

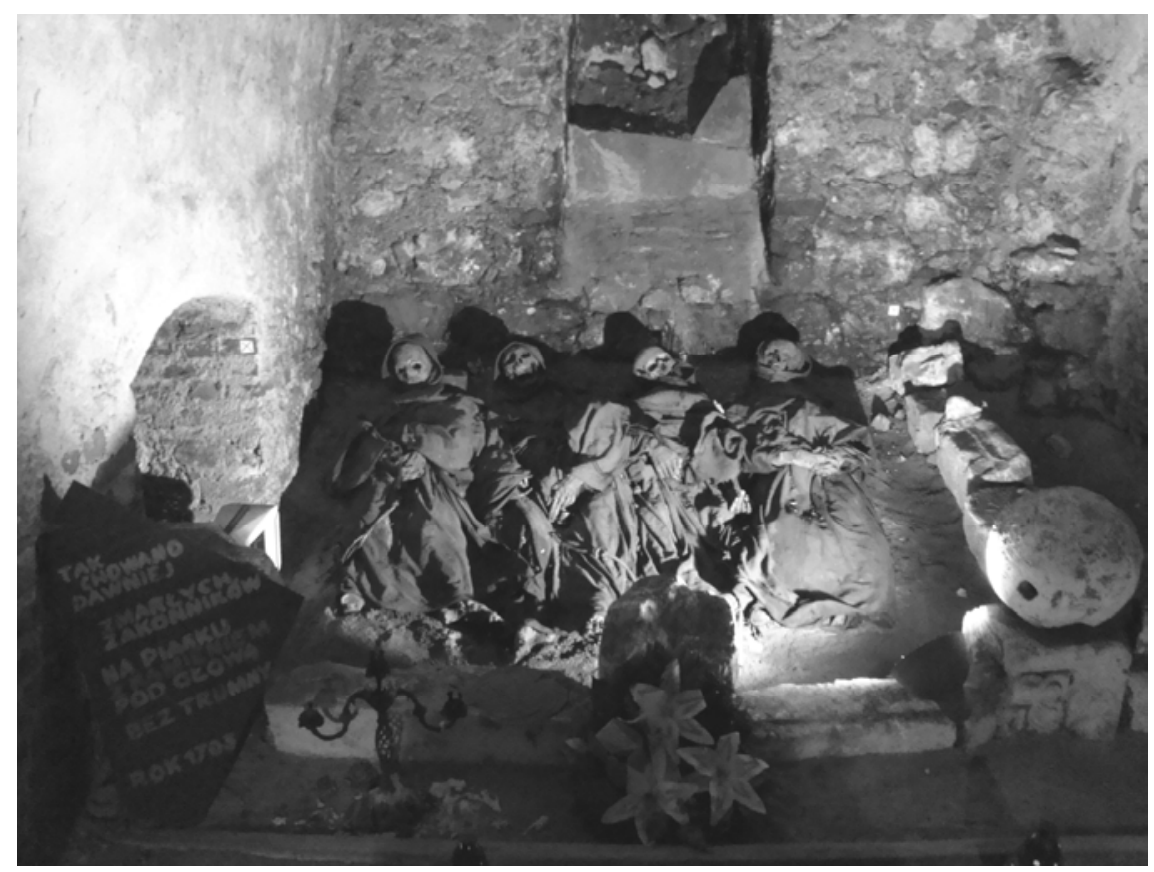

Fot. 8. Krypta w kościele oo. Reformatów w Krakowie - Polska (autor: S. Tanaś)

Kultura w wymiarze symbolicznym jest zróżnicowana, co może implikować trudności $\mathrm{w}$ jej wartościowaniu. Widz, którym jest również turysta, polega w swej ocenie na wartościowaniu kultury, najczęściej przez pryzmat zawartych $\mathrm{w}$ przekazie sugestii dostosowanych do masowego odbioru. $\mathrm{W}$ trakcie spotkań z odmiennymi lub nieznanymi aspektami kultury turysta ma szansę na identyfikację i interpretację jej elementów. Nowo poznana kultura jest dla turysty niefunkcjonalna. Jednak poprzez zmianę własnych przekonań i oderwanie od bezpośredniego użytkowania elementy kultury 
otrzymują nowe zastosowanie. Cmentarz nie pełni tylko funkcji grzebalnej czy religijnej, jest także odkrywaną przestrzenią poznawczą i rekreacyjną (TANAŚ 2008b). Użytkowe i symboliczne znaczenie przestrzeni śmierci wraz z postępującym procesem poznawczym staje się oczywiste, jednak zrozumienie tego może nastręczać turyście kłopotu, szczególnie wówczas gdy wytwór kultury funkcjonuje $\mathrm{w}$ innym kontekście, niż w którym powstał. Turysta poszukuje wtedy klucza do zrozumienia znaczenia elementu kultury, niejednokrotnie $\mathrm{w}$ sposób etnocentryczny. Turysta może mieć trudności z interpretacją i oceną, np. przetrzymywania zwłok zmarłego członka rodziny w domu do momentu jego naturalnej mumifikacji i czasu zebrania odpowiedniej liczby zwierząt hodowlanych wystarczającej do rytualnego pogrzebu (Indochiny). Mimo to dąży do bezpośredniego kontaktu z makabrycznym, $w$ jego rozumieniu, rytuałem pogrzebowym.

Podróże turystyczne pobudzają mechanizmy obiegu kultur i rozbudzają potrzeby kulturalne. Tak jak kultura artystyczna i niematerialne dziedzictwo kulturowe, również sztuka sepulkralna funkcjonuje w systemie obiegu poprzez wystawy, zbiory czy obiekty sakralne skomercjalizowane pod wpływem turystyki (np. wystawy sztuki sepulkralnej i funeralnej, krypty kościelne, ossuaria, cmentarze). Działania poznawcze, poprzez fakt obiektywizacji wytworów kulturowych i ich opis odpowiednio przygotowanym językiem, przyczyniają się do obiegu wiedzy na poziomie kultury masowej i skutkują rozbudzaniem kolejnych potrzeb kulturalnych. Poznanie symboliki i filozoficznych aspektów śmierci, tradycji pogrzebowych, śmierci dzięki podróżom tanatoturystycznym może przyczynić się do dalszego zainteresowania eschatologią, tanatologią, religią i skutkować zmianami osobowości, postaw wobec życia itp. Bezpośredni kontakt z przedmiotem poznania, w tym przypadku z kulturą funeralną i sepulkralną, może przyczynić się do zwiększonego zainteresowania określonymi elementami kultury.

Kulturotwórcza rola turystyki kulturowej, polegającą na jej uspołecznianiu, może prowadzić do upublicznienia stosunkowo marginalnych cech kultur, a taką cechą europejskiej kultury jest współczesna marginalizacja śmierci.

\subsubsection{TURYSTYCZNA PERCEPCJA KULTURY}

Komercjalizacja kultury, czyli przekształcanie jej w produkt rynkowy, jest zjawiskiem powszechnym wszędzie tam, gdzie powstał i rozwija się przemysł i gospodarka rynkowa, jest czynnikiem homogenizacji kultur za pośrednictwem środków masowego przekazu działających w skali globalnej (ROMANISZYN 2010, s. 42-43). 
Kultura elitarna (wysoka) i kultura popularna (niska) definiowane były przez wielu autorów (KŁOSKOWSKA 2005, GOLKA 2008). Kultura elitarna jest wyrafinowanym elementem systemu kultury, wyodrębnionym ze względu na treść, cechy formalne oraz przesłanie moralne. Kultura popularna to kultura lokalna, służąca rozrywce, upowszechniona przez masowe media. Wyróżnia się przeciętnością i niekoniecznie zawiera przekaz moralny. Obie przesądzają o swoistości kultury, której komercjalizacja prowadzi do dewaluacji symboli i wartości podstawowych (np. dewaluacja szacunku wobec śmierci).

J. URRY (2007) uważa, że zwiedzane miejsca wybiera się ze względu na oczekiwane przeżycie doświadczeń odmiennych od codziennych. Turysta jest bardziej uwrażliwiony na wizualność, reprodukcję fotograficzną. Spojrzenie turysty koncentruje się na znakach, symbolach, a sektor turystyczny zajmuje się produkcją artefaktów przeznaczonych dla tego spojrzenia. Turysta jest uwrażliwiony na wizualność reprodukowaną przez fotografię i rysunki. Istotnym aspektem badań J. URRY'EGO (2007) jest twierdzenie, że $\mathrm{w}$ doświadczeniu turystycznym najistotniejsze są zmysły wzroku i słuchu.

Wizualizacja cechuje współczesną turystykę ponowoczesną (COHEN 2011, WIECZORKIEWICZ 2008), która narodziła się wraz z rozwojem społeczeństwa ponowoczesnego (BAUMAN 2000b, 2006a, GIDDENS 2001, SMART 1998). Charakteryzują ją (URRY 2007):

a) konsumpcja - „konsumujemy” raczej znaki i obrazy niż prawdziwe rzeczy; są to kopie oryginału (śmierci), a idea tego, czym był oryginał zostaje stopniowo utracona;

b) zmieniająca się tożsamość - społeczeństwo jest znacznie mniej zakorzenione w czasie i przestrzeni niż ludy żyjące w poprzednich epokach; dzięki mediom i częstym podróżom znajome są dla nas rozmaite reprezentacje różnych kultur i miejsc; tracimy poczucie siebie i zostajemy wciągnięci $\mathrm{w}$ grę $\mathrm{z}$ różnymi doświadczeniami i obrazami, która paradoksalnie może wyzwalać pragnienie autentycznego przeżycia;

c) wzrastający wpływ klasy średniej - rośnie konsumpcja klasy średniej uważanej za klasę „usługową”.

Spojrzenie związane z grozą J. URRY (2007) klasyfikuje jako spojrzenie romantyczne, widowiskowe oraz zbiorowe. Spojrzenie romantyczne kieruje się na "piękno" lub „widowisko", spojrzenie zbiorowe związane jest z liczbą odbiorców, a interakcja między spojrzeniem romantycznym i zbiorowym tworzy atmosferę miejsca (rys. 18).

To co widzimy, jest uwarunkowane tym, co wiemy, a to co wiemy, jest skutkiem procesu edukacji i socjalizacji. Sposób patrzenia i wyciągania wniosków z obserwacji jest ściśle powiązany z kulturą wizualną opartą na 
patrzeniu i interpretowaniu obrazu (SIMMEL 2006), również przestrzeni geograficznej.

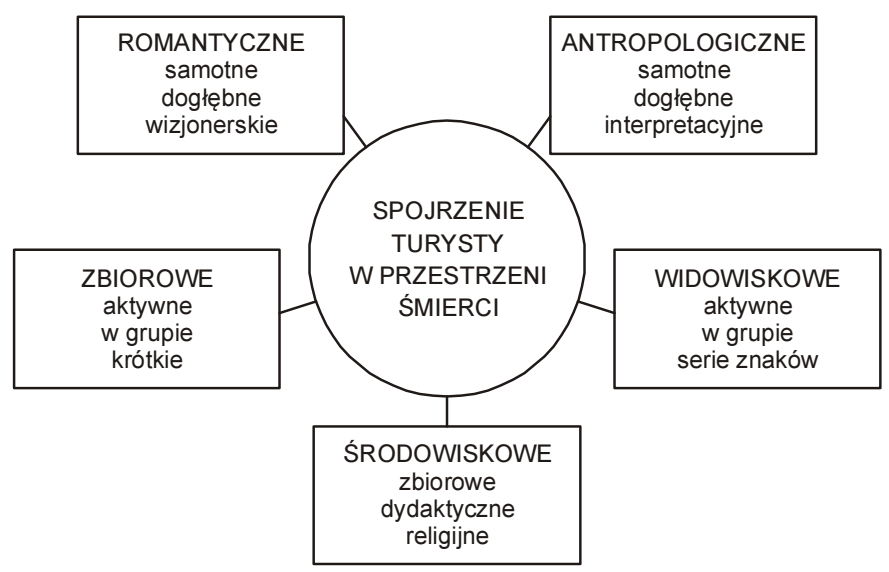

Rys. 18. Rodzaje spojrzenia turystycznego w przestrzeni śmierci Źródło: opracowanie własne na podstawie J. URRY'EGO (2007)

Kreowanie sztucznych atrakcji turystycznych, kulturowo jałowych, nieprzypisanych do miejsca i pozbawionych historii tworzy nowy typ turysty, jakim jest turysta ponowoczesny (WINIARSKI, ZDEBSKI 2008). Typ ten widoczny jest w mrocznej turystyce, w której kreowane są repliki i atrakcje dostarczające wyrafinowanych i doskonale skalkulowanych przeżyć oraz doświadczeń. Są to m.in. wizyty w obiektach rozrywki i muzeach, w których można zobaczyć artefakty zastępujące kontakt $\mathrm{z}$ realnym cierpieniem i śmiercią. Współczesna popkulturowa turystyka masowa stała się wyreżyserowanym widowiskiem (MACCANNELL 2002), realizowanym według ustalonego scenariusza. Tworzenie sztucznych przestrzeni śmierci stanowi alternatywę dla tradycyjnych przestrzeni turystycznych, w których turysta doznaje kontaktu $\mathrm{z}$,"kreacją" cierpienia i śmierci. W rzeczywistości kontakt ten służy zabawie, mniej edukacji czy wychowaniu.

\subsubsection{TURYSTYCZNY DYSTANS MIĘDZYPOKOLENIOWY}

W życiu społecznym, również w działalności turystycznej (poznawczej i wypoczynkowej), zachodzą zmiany mające charakter ewolucyjny (stopniowe przejście z jednego porządku do drugiego) lub rewolucyjny (załamanie się dawnego ładu i zastąpienie go innym). Charakter turystyki kulturowej zmienia się wraz ze zmieniającymi się turystycznymi preferencjami kolejnych po- 
koleń. Wpływ na te zmiany mają przede wszystkim motywy podróży turystycznych, które determinowane są m.in. walorami turystycznymi, dostępnością komunikacyjną i zagospodarowaniem turystycznym. Rozwój technologii informatycznych i przekazu medialnego skutkuje dostępem do informacji i wiedzy o skali, która 30 lat temu była jeszcze niemożliwa. Idące $\mathrm{w}$ parze z rewolucją medialną przemiany kulturowe dystansują szczególnie od siebie pokolenia najstarsze i najmłodsze. Przestrzeń geograficzna jest dziś dostępna dla turysty jak nigdy wcześniej, jednak możliwości i jakość eksploracji i penetracji tej przestrzeni uzależniona jest w dużej mierze od czynników społecznych.

R. WINIARSKI i J. ZDEBSKI (2008) dokonali próby przyporządkowania charakteru aktywności turystycznej do fazy życia (ZDEBSKI 2006), wyodrębniając:

- późne dzieciństwo jako fazę przygotowawczą do rozwoju aktywności turystycznej;

- fazę spontanicznej aktywności turystycznej i kształtowanie się specjalizacji w wieku młodzieńczym;

- fazę stabilizacji aktywności turystycznej w wieku średnim;

- fazę ożywienia aktywności turystycznej w wieku dojrzałym;

- fazę inwolucji i zaniku aktywności turystycznej w wieku starczym.

Opierając się na koncepcji dystansu międzypokoleniowego M. MEAD (1978), różnicującej społeczeństwo na trzy typy pokoleniowe, oraz na przedstawionych wcześniej zagadnieniach związanych z turystyką i kulturą autor wyróżnia trzy etapy ewolucji turystyki: postfiguratywny, kofiguratywny i prefiguratywny.

Turystyka postfiguratywna - kształtująca się na podstawie odchodzącej kultury przodków - występuje przede wszystkim w społeczeństwach tradycyjnych, wąskich grupach religijnych i ideologicznych, które są już po okresie intensywnej ekspansji i wchodzą $\mathrm{w}$ fazę schyłkową (przemijającą "post"). Znany jest w nich jeden sposób życia, wspólny dla wszystkich, pokolenie dzieci kształtowane jest $\mathrm{w}$ procesie socjalizacji na wzór i podobieństwo rodziców, czego skutkiem jest bezwzględne uznanie obowiązujących norm społecznych. Zmiany zachodzą z tego powodu wolno lub wcale. Jest to wyizolowana kultura, w której pamięć o przeszłości przechowywana jest w pamięci członków rodziny. Charakterystyczna jest domena zwyczaju i tradycji, kultu starszyzny łączącej generacje. Dzięki tradycji przenoszone są wzorce ról społecznych.

W kulturze postfiguratywnej mamy tradycyjny pogląd na turystykę. Młoda generacja turystów kształtowana jest na wzór utartego modelu turystyki, którą można określić turystyką tradycyjną. Z braku konkurencyjnych wzorów zachowań turystycznych, w warunkach pewnej izolacji środowiska 
wychowawczego, młodzież z reguły naśladuje swoich mentorów - rodziców, nauczycieli, przewodników. Turystykę postfiguratywną (przemijającą) charakteryzują tradycyjne, $\mathrm{w}$ formie i motywie, kulturowe podróże poznawcze i rekreacyjne podróże wypoczynkowe.

Turystyka kofiguratywna - kształtująca się w kulturze rówieśników występuje m.in. w społeczeństwach przemysłowych, gdzie młoda i średnia generacja współpracuje na zasadach równorzędnych partnerów. Młode pokolenie jest mobilne, zmienia miejsce zamieszkania nabywając nowych nawyków. Wśród grupy rówieśników pojawia się kultura masowa (LUTY-MICHALAK 2010). We wszystkich kulturach kofiguratywnych starsi, traktowani jako rówieśnicy, nadal odgrywają podstawową rolę, określając formy i granice, w których może wystąpić kofiguracja w zachowaniu młodych ludzi, przyjmujących typowe dla swojej generacji normy jako naturalne. Kofiguracja powstaje $\mathrm{w}$ wyniku rozpadu systemu postfiguratywnego na skutek pojawienia się rewolucyjnych bodźców. Przodkowie nie są w stanie dostarczyć młodemu pokoleniu wzorców zachowań odpowiednich dla ich wieku, dlatego występując w roli rówieśników muszą odkryć nowe style postępowania i przekazywać je jako wzór.

W kulturze kofiguratywnej rodzi się różny od tradycyjnego pogląd na turystykę, który podlega modyfikacjom uzależnionym od charakteru zainteresowania i potrzeb turystycznych. Turystyka kofiguratywna polega na wspólistnieniu zachowań turystycznych młodej, średniej i starszej generacji. Warunkiem wspólistnienia jest stosunkowo duża tolerancja wobec postaw i zachowań generacji młodych turystów. Jest to sytuacja, w której turyści przyjmują jako normę, że każda generacja różni się od poprzedniej potrzebami, motywami i zainteresowaniami.

Turystyka prefiguratywna - nowoczesna turystyka młodych pokoleń w rodzącej się kulturze "zagadkowych potomków", będących na etapie kształtowania się, przed intensywną ekspansją. Starsze i średnie pokolenia zmuszane są do uznania niezależności młodzieży, ucząc się od niej nowych postaw i zachowań, narzuconych przez zmieniający się rytm życia społecznego. Skutkiem tego jest rozłam międzypokoleniowy, w wyniku którego następuje odwrócenie socjalizacji, ponieważ to młode pokolenie staje się nauczycielem pokoleń starszych. Tradycja i doświadczenie zdobywane przez całe życie może być przeszkodą $\mathrm{w}$ adaptacji do szybko zmieniających się warunków życia. Młode pokolenie odrzuca wiedzę i doświadczenie swoich rodziców czy dziadków. Nabyte w przeszłości postawy i doświadczenia turystyczne przestają być powodem do dumy, wręcz stają się przeszkodą w teraźniejszym doświadczeniu podróżniczym. Turysta prefiguratywny to nieprzewidywalny turysta ponowoczesny, postindustrialny. 
Rysunek 19 przedstawia turystyczny dystans pokoleniowy, wynikający z postępujących zmian kulturowych i cywilizacyjnych (niejednokrotnie rewolucyjnych), wraz z charakterystyką poszczególnych typów turystyki obejmującą przykładowy czas występowania, cechy, specyfikę podróży i sposób interpretacji śmierci.

\begin{tabular}{|c|c|c|c|c|}
\hline $\begin{array}{c}\text { TURYSTYKA } \\
\text { POSTFIGURATYWNA }\end{array}$ & & $\begin{array}{c}\text { TURYSTYKA } \\
\text { KOFIGURATYWNA }\end{array}$ & & $\begin{array}{c}\text { TURYSTYKA } \\
\text { PREFIGURATYWNA }\end{array}$ \\
\hline $\mathrm{XIX} / \mathrm{XX}$ & \multirow{5}{*}{ 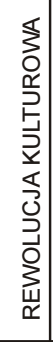 } & $x x$ & \multirow{5}{*}{ 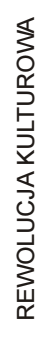 } & $X X / X X I$ \\
\hline $\begin{array}{c}\text { kult tradycji } \\
\text { ograniczone potrzeby } \\
\text { ograniczona komunikacja }\end{array}$ & & $\begin{array}{c}\text { wolność } \\
\text { wzrost potrzeb } \\
\text { rozwój komunikacji }\end{array}$ & & $\begin{array}{l}\text { negacja tradycji } \\
\text { rozwój informacji } \\
\text { konsumpcjonizm }\end{array}$ \\
\hline TURYSTA TRADYCYJNY & & TURYSTA NOWOCZESNY & & TURYSTA PONOWOCZESNY \\
\hline TURYSTYKA ELITARNA & & TURYSTYKA MASOWA & & $\begin{array}{l}\text { INDYWIDUALIZACJA } \\
\text { TURYSTYKI MASOWEJ }\end{array}$ \\
\hline EKSPLORACJA & & PENETRACJA & & $\begin{array}{c}\text { PENETRACJA } \\
\text { REEKSPLORACJA }\end{array}$ \\
\hline śmierć romantyczna & & $\begin{array}{c}\text { śmierć brutalna } \\
\text { tabu }\end{array}$ & & $\begin{array}{c}\text { śmierć odległa } \\
\text { przełamywanie tabu }\end{array}$ \\
\hline
\end{tabular}

Rys. 19. Turystyczny dystans międzypokoleniowy w powiązaniu z interpretacją śmierci Źródło: opracowanie własne

Turystyka postfiguratywna jest turystyką tradycyjną i elitarną. Jeżeli przyjmiemy kryterium czasowe, to można nią określić turystykę XIX i początku XX stulecia. Turystyka postfiguratywna nie jest, podobnie jak pozostałe wyróżnione przez autora etapy turystyki, rozróżniana wyłącznie za pomocą kryterium czasu. Figuratywność jest względna, co oznacza, że może być rozpatrywana zarówno historycznie, jak i przestrzennie. Charakterystyczna dla turystyki postfiguratywnej jest eksploracja, odkrywanie przestrzeni geograficznej (przestrzeń eksploracji), ale rozumiane przede wszystkim w aspekcie indywidualnej i mentalnej przestrzeni turystycznej. Podróże do przestrzeni śmierci mają $\mathrm{w}$ tym przypadku charakter romantyczny, uduchowiony, nacechowany kontemplacją, zadumą nad życiem i śmiercią.

Turystyka kofiguratywna jest turystyką nowoczesną, XX-wieczną, masową i popularną. Turysta poszukuje nowych doznań i doświadczeń, korzystając z przygotowanego produktu turystycznego. Podróże mają raczej charakter masowej penetracji, podczas której zainteresowanie wzbudza obiekt lub miejsce szokujące, rodzące emocje (strach, żal, zabawę). W centrum zainteresowania jest popkulturowy charakter kultury śmierci. Emocje wzbudzają nie tylko doświadczenia wzniosłe - poznanie, edukacja, kontemplacja, ale przede wszystkim widok, obraz, narracja. Interpretacja miejsca opiera się głównie na spojrzeniu i doznaniach. Dominuje zainteresowanie obrazem 
śmierci brutalnej przy jednoczesnym traktowaniu własnej śmiertelności jako tematu tabu.

Turystyka prefiguratywna, która rozpatrywana w kategoriach czasu jest turystyką przełomu wieków XX i XXI, a w kategoriach socjologicznych będzie turystyką ponowoczesną, o wyraźnym zabarwieniu konsumpcyjnym i postmodernistycznym, jest turystyką negowaną przez turystów postfiguratywnych i kofiguratywnych. Turysta prefiguratywny, który odwraca się od tradycji, poszukuje nieznanych dotąd doznań (rozwój turystyki ekstremalnej, niebezpiecznej, zakazanej). Następuje indywidualizacja turystyki masowej (MAZURKIEWICZ 2007). Podczas masowych podróży rodzi się indywidualne postrzeganie przestrzeni turystycznej. Indywidualny turysta dysponuje swoim planem podróży, nie uwzględnia w nim w takim stopniu jak turysta grupowy oferty biur podróży, a równocześnie w nieco większym stopniu jest wrażliwy na informację tranzytową i miejscową. Jest to turysta zarówno penetrujący przestrzeń geograficzną, jak i reeksplorujący, indywidualnie odkrywający na nowo walory już poznane i masowo penetrowane, lub odkrywający nowe, wcześniej nieturystyczne przestrzenie. W przypadku przestrzeni śmierci, motywem podróży do niej będzie traktowanie śmierci jako odległej, niedotykającej turysty „śmierci odrzuconej”, przy jednoczesnym przełamywaniu tabu śmierci istniejącego w kulturach kofiguratywnych.

Zaprezentowana koncepcja turystycznego dystansu międzypokoleniowego ma na celu wyjaśnienie przyczyn i skutków, jakie są związane z turystycznym zainteresowaniem wytworami kultur, w szczególności wytworami kultury śmierci. Koncepcja ta zostanie wykorzystana również do próby analizy zmian zachodzących $\mathrm{w}$ indywidualnej i kulturowej przestrzeni turystycznej, dyskutowanej w ramach geografii turyzmu.

\subsection{ZWIAZZKI PRZESTRZENI ŚMIERCI Z PRZESTRZENIĄ TURYSTYCZNA}

Prowadzone od lat pięćdziesiątych XX wieku badania nad przestrzenią turystyczną obejmują szerokie spektrum zagadnień przestrzennych związanych $z$ badaniami geografii turyzmu (WŁODARCZYK 2009). Nawiązując do geograficzno-kulturowego charakteru badań nad przekształceniami przestrzeni śmierci w przestrzeń turystyczną autor skupi się jedynie na analizie wybranych koncepcji przestrzeni turystycznej, które mogą służyć wyjaśnieniu jej związków z przestrzenią śmierci. 
Istotę, koncepcje i determinanty rozwoju przestrzeni turystycznej w ujęciu geograficznym badał B. WŁODARCZYK (2006), który w obszernym opracowaniu (WŁODARCZYK 2009) dokonał szczegółowej analizy dorobku naukowego obejmującego studia nad przestrzenią turystyczną. Na uwagę zasługują publikacje S. LISZEWSKIEGO $(1995,1999,2005,2006)$ i A. KOWALCZYKA (2000, 2011), w których autorzy dokonali konceptualizacji przestrzeni turystycznej. S. LISZEWSKI (1995) wyróżniał typy przestrzeni turystycznej, z których istotna dla tanatoturystyki jest przestrzeń eksploracji i penetracji. A. KOWALCZYK (2000) oparł swoją koncepcję na etapach poznawania przestrzeni turystycznej (eksploracji, penetracji, segregacji i specjalizacji). Koncepcja czasoprzestrzeni turystycznej opisana została przez R. KNAFOU (1998). Ekonomiczne koncepcje przestrzeni turystycznej, uwzględniające relacje między podażą a popytem turystycznym, przedstawiły B. MEYER (2004) i A. NIEZGODA (2006). Badania nad przestrzenią turystyczną $w$ aspekcie religijnym prowadził A. JACKOWSKI (2003), a N. LEIPER (1979) opisał przestrzeń, w ramach której wyodrębnił środowisko kulturowe. A. LISOWSKI (2003) lokuje przestrzeń turystyczną w przestrzeni ekologicznej, definiowanej jako zbiór przedmiotów warunkujących zaspokojenie potrzeb podmiotu (turysty). Przestrzeń ekologiczna, obok przestrzeni kulturowej i społecznej, jest częścią przestrzeni niefizycznej, obejmującej zbiór przedmiotów będących $\mathrm{w}$ relacji z poznającym i działającym podmiotem, np. turystą czy pielgrzymem.

Przestrzeń turystyczna nie jest jednorodna (LISZEWSKI 1995). W aspekcie badania związków i współzależności przestrzeni turystycznej z przestrzenią śmierci można odwołać się do modelu M. OPPERMANNA (1993). Wyróżnił on przestrzeń nieturystyczną, z której może wykształcić się przestrzeń turystyczna nieformalna (równoległa), obejmująca wszelkie działania i formy zagospodarowania niemające charakteru instytucjonalnego, oraz przestrzeń turystyczna formalna (oficjalna), zawierająca zinstytucjonalizowane elementy zagospodarowania turystycznego.

Zdaniem autora przestrzeń śmierci można sytuować w przestrzeni nieturystycznej, choć nie jest to jedyny warunek. Wraz z pojawieniem się zainteresowania poznawczego $\mathrm{w}$ przestrzeni śmierci zacznie rozwijać się początkowo nieformalna przestrzeń tanatoturystyki, wynikająca z kulturowych ogranczeń wykorzystania wytworów kultury śmierci do celów komercyjnych. Z czasem jednak przestrzeń ta zostanie $\mathrm{w}$ pewnym stopniu sformalizowana, zinstytucjonalizowana, głównie w wyniku działających czynników ekonomicznych prowadzących do wykorzystania dziedzictwa kultury śmierci na potrzeby określonych produktów, w tym produktów turystycznych (rys. 20).

Koncepcja przestrzeni turystycznej H. ALDSKOGIUSA (1977) dotyczy prawidłowości w wyborze indywidualnej przestrzeni turystycznej. Determinan- 
ty kształtujące tego rodzaju przestrzeń prowadzą do wytworzenia wyobrażeń poznawczych o charakterze przestrzennym, konsekwencją czego jest ukształtowanie tzw. przestrzeni akcji, czyli zbioru potencjalnych możliwości rozpatrywanych przez turystę jako powód wyjazdu turystycznego. W dalszej kolejności następuje uwzględnienie wszelkich uwarunkowań zewnętrznych wpływających na wybór tzw. przestrzeni aktywności, która w wyniku konsumpcji staje się indywidualną przestrzenią turystyczną człowieka (WŁODARCZYK 2009, s. 44-47). Koncepcja ta może wyjaśniać indywidualny sposób wyboru i percepcji odwiedzanych turystycznie przestrzeni śmierci. Czynnikami kształtującymi indywidualną przestrzeń tanatoturystyki mogą być np. informacje medialne, moda, pamięć, historia, kultura.

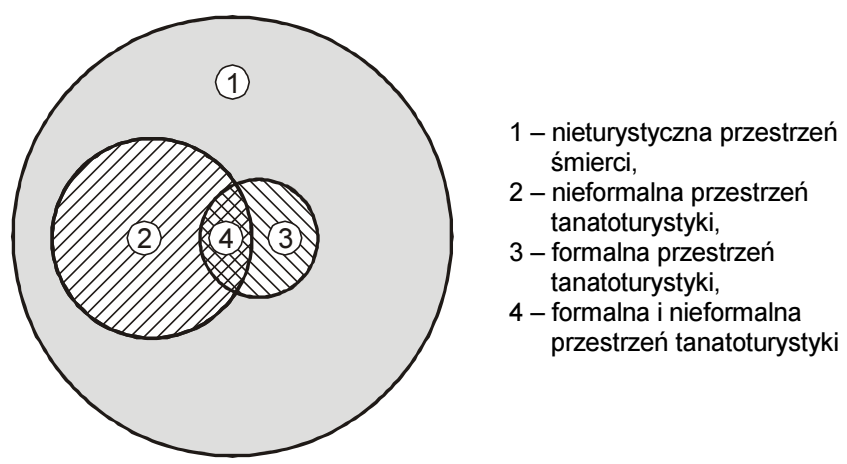

Rys. 20. Schematyczny model przestrzeni tanatoturystyki na podstawie M. OPPERMANNA (1993)

Przestrzeń aktywności turystycznej jest bardzo zindywidualizowana, subiektywna, tak jak jest nią przestrzeń śmierci. Wybór miejsca podróży turystycznej jest determinowany informacją, wiedzą i doświadczeniem, które poprzez określone filtry zewnętrzne (źródła informacji, środowisko społecznokulturowe) i wewnętrzne (cechy społeczno-demograficzne człowieka, jego historia) określają preferencje podróżnicze (np. poznawcze, religijne czy rozrywkowe). Opierając się na stworzonym systemie preferencji i potrzeb turysta wchodząc $\mathrm{w}$ kontakt $\mathrm{z}$ kulturą śmierci kształtuje swoje wyobrażenia o śmierci i cierpieniu, które modyfikowane są przez walory mogące stanowić o atrakcyjności miejsca. Turysta w zależności od określonych potrzeb dokonuje wyboru formy aktywności (turystycznej, rekreacyjnej), które z kolei po uwzględnieniu dostępności miejsca do realizacji postawionych celów kształtują indywidualną przestrzeń turystyczną $\mathrm{w}$ ramach przestrzeni śmierci (rys. 21). 


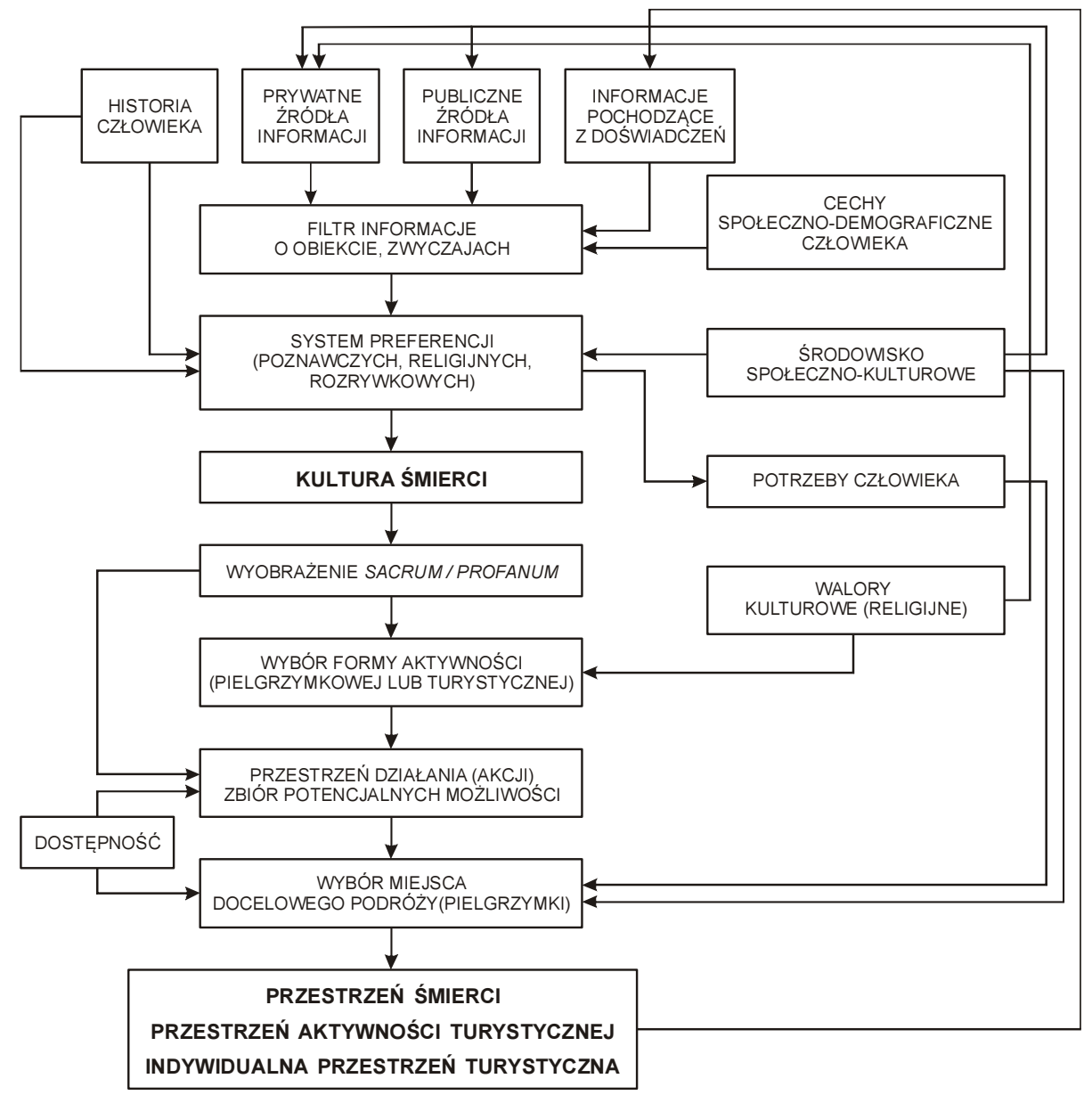

Rys. 21. Teoretyczny model zachowań turystycznych a kształtowanie indywidualnej przestrzeni turystycznej w przestrzeni śmierci

Źródło: opracowanie własne na podstawie prac H. ALDSKOGIUSA (1977)

i B. WEODARCZYKA (2009)

Cykl życia obszaru turystycznego R. BUTLERA (1980) może być pomocny w wyjaśnieniu zależności zmian wielkości ruchu turystycznego, również w odniesieniu do cyklu życia produktu. Przykładem analizy może być taki wycinek przestrzeni geograficznej, który na skutej degradacji lub umownej "śmierci" wzbudzi zainteresowanie turystyczne i doprowadzi do przemian funkcjonalnych uwzględniających funkcję turystyczną. Choć teoria R. Butlera dotyczyła kurortów nadmorskich, to jej wykorzystanie, w przypadku zaburzeń związanych z katastrofą, wojną, atakiem terrorystycznym i innymi czynnikami niosącymi zagrożenie życia ludzkiego lub w przypadku funkcjo- 


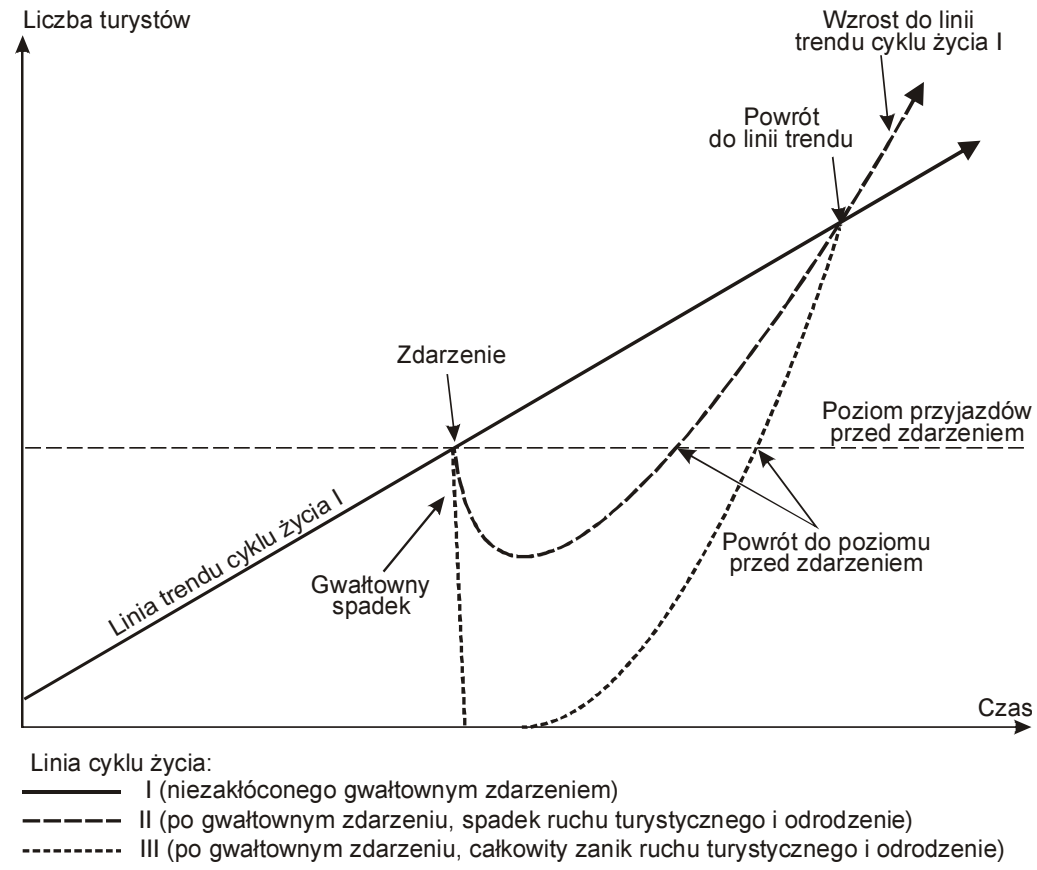

Rys. 22. Cykl życia obszaru turystycznego zachwianego gwałtownym zdarzeniem (katastrofą, aktem przemocy, śmiercią)

Źródło: opracowanie własne na podstawie R. BUTLERA (1980)

nalnej „śmierci” fragmentu przestrzeni geograficznej, wydaje się stosunkowo ciekawe.

Rysunek 22 przedstawia cykl ustabilizowanego rozwoju przestrzeni turystycznej zachwianego gwałtownym zdarzeniem, niosącego ze sobą destrukcję zagospodarowania, zagrożenie bezpieczeństwa lub śmierć turystów. Konsekwencją tego jest gwałtowne zahamowanie rozwoju przestrzeni turystycznej lub jej całkowity upadek. Jednak wraz z upływam czasu przestrzeń turystyczna może się odrodzić, a wielkość ruchu turystycznego może powrócić do wcześniejszej linii trendu. Możliwy jest ponadto scenariusz, w którym gwałtowne zdarzenie będzie impulsem do szybszego rozwoju obszaru turystycznego, niż wynikałoby to z pierwotnego trendu. Wtórną przyczyną może być powstanie np. obiektu upamiętniającego śmierć, ulepszenie zagospodarowania turystycznego lub dostępności komunikacyjnej. Należy założyć, że w przypadku zaistnienia w przestrzeni geograficznej, nieposiadającej cech przestrzeni turystycznej, zdarzenia, konsekwencją którego jest śmierć podmiotowa lub przedmiotowa, przestrzeń ta $\mathrm{w}$ wyniku pojawienia się ruchu turystycznego przekształci się początkowo w nieformalną prze- 
strzeń turystyczną, która z czasem może zostać uznana za formalną przestrzeń tanatoturystyki.

Zgodnie z wcześniejszymi ustaleniami, przestrzeń śmierci obejmuje również przestrzeń przedmiotową (rzeczy, budynki, miejsca, obszary). Przestrzeń geograficzna, zarówno przyrodnicza, jak i antropogeniczna, podlegając procesom społeczno-ekonomicznym może ulec degradacji, efektem czego będzie „śmierć" tej przestrzeni. Konsekwencją „śmierci” przestrzeni społeczno-geograficznej może być jej odrodzenie w zupełnie nowej formie. S. KACZMAREK (2001) wskazała na możliwości odrodzenia przestrzeni poprzemysłowych przez rewitalizację. $W$ ten sposób obiekty przeznaczone do wyburzenia („uśmiercenia”) odzyskują nowe życie. Model Butlera można zastosować do analizy cyklu życia „uśmierconych” przestrzeni, które w wyniku procesów rewitalizacyjnych otrzymały nowe funkcje, m.in. bazujące na dziedzictwie i historii miejsca, funkcje turystyczne. Przykładem może być strefa World Trade Center w Nowym Jorku (LISLE 2004), na terenie której po zamachu terrorystycznym z 2001 roku zorganizowano nową przestrzeń, pełniącą również funkcję memoratywną, czy zrewitalizowane doki londyńskie, na obszar których po okresie upadku, wprowadzono m.in. handel, usługi i rekreację, tworząc nową strefę miejskiego życia społecznego.

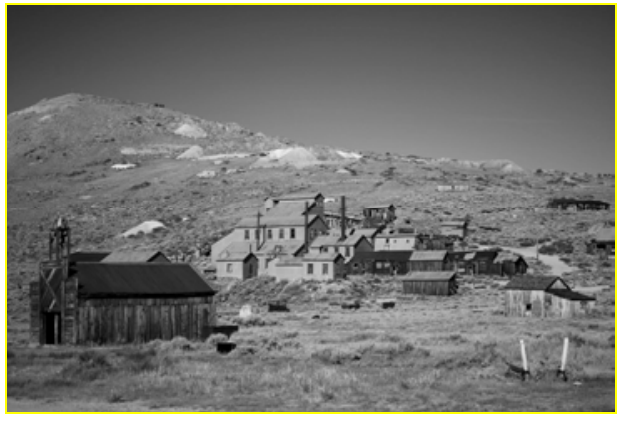

Fot. 9. Wymarła osada górnicza Bodie w Kalifornii (USA); obecnie park historyczny Źródło: materiały informacyjne Bodie State Historic Park

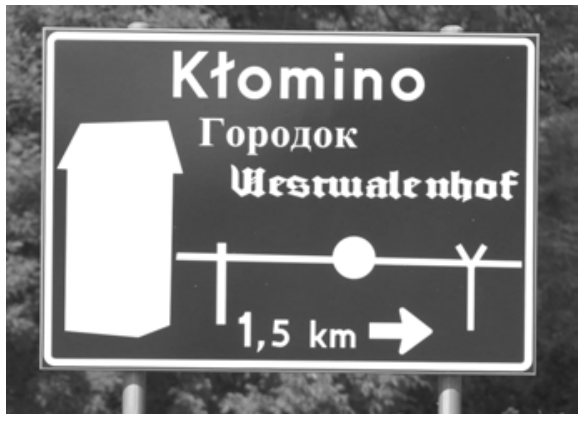

Fot. 10. Tablica informacyjna kierująca do osady Kłomino (autor: S. Tanaś)

Do przedmiotowej przestrzeni śmierci zaliczyć można obszary wymarłych i opuszczonych miast, w których z czasem rozwinęla się nieformalna funkcja turystyczna (np. Prypeć - Ukraina, Hashima - Japonia, Varosha Cypr, Agdam - Azerbejdżan, Craco - Włochy, Oradour-sur-Glane - Francja) (SMOLEŃSKA 2012). W Stanach Zjednoczonych powszechne są opuszczone miasteczka pokopalniane, zwane ghost towns - „miasta duchów”, ",wymarłe 
miasta" (DELYSER 1999, EBERHART 1981), które niejednokrotnie zostały objęte ochroną w postaci parków historycznych, jak np. osada górnicza Bodie w Kalifornii (fot. 9). W Polsce popularnym miejscem odwiedzanym turystycznie jest dawna osada garnizonowa Armii Czerwonej w Kłominie k. Bornego Sulinowa (fot. 10).

W ograniczonym stopniu można zastosować w analizie rozwoju przestrzeni tanatoturystyki modelowe ujęcie przestrzeni turystycznej S. LISZEWSKIEGO (1995). Przestrzeń śmierci może być zaadaptowana turystycznie jedynie $w$ ramach przestrzeni eksploracji turystycznej (odkrywania nowych przestrzeni w ramach działalności poznawczej) i penetracji turystycznej (masowego odwiedzania przestrzeni śmierci przez turystów). Przykładem wykorzystania tej koncepcji jest turystyczna eksploracja i penetracja nekropolii (TANAŚ 2008b).

Aby jednoznacznie zdefiniować pojęcie przestrzeni turystycznej na potrzeby pracy przyjęto zmodyfikowaną definicję S. LISZEWSKIEGO (1995) i B. WŁODARCZYKA (2009):

Przestrzeń turystyczna jest funkcjonalnie wyróżniającą się podprzestrzenią przestrzeni geograficznej, na którą składają się elementy przyrodnicze i trwałe efekty działalności ludzkiej w jej środowisku, a także środowisko człowieka $\mathrm{w}$ rozumieniu społecznym. Jest to przestrzeń geograficzna, w której występuje zjawisko ruchu turystycznego, niezależnie od jego wielkości i charakteru. Ruch turystyczny może być wspomagany zagospodarowaniem turystycznym, choć nie jest to warunek konieczny.

B. WŁODARCZYK (2009) uważa, że obiektywnym atrybutem przestrzeni turystycznej jest zaklasyfikowanie jej do przestrzeni geograficznej, subiektywnym natomiast fakt konieczności występowania w tej przestrzeni człowieka, uczestnika ruchu turystycznego, którego obecność pozwala nie tylko na jej delimitację, ale także poprzez podejmowanie określonych decyzji kształtuje własną, indywidualną przestrzeń aktywności turystycznej. Do składników tej przestrzeni, wydzielonej również w obrębie przestrzeni śmierci, zaliczymy:

- dziedzictwo przyrodnicze (budowa geologiczna, ukształtowanie terenu, wody, warunki klimatyczne, szata roślinna i świat zwierzęcy, w szczególności świat ożywiony podlegający procesom, efektem których jest śmierć w rozumieniu biologicznym);

- dziedzictwo kulturowe (zasoby powstałe w wyniku działalności ludzkiej, w tym materialne i duchowe dziedzictwo kulturowe, będące następstwem śmierci, głównie upamiętniające i rytualizujące śmierć, jak również śmierć w rozumieniu zdarzenia stanowiącego o kresie życia podmiotowego i przedmiotowego); 
- infrastrukturę (zasoby uzupełniające elementy pierwotne, udostępniające dziedzictwo przyrodnicze i kulturowe na potrzeby turystyki, warunkujące jego wykorzystanie);

- człowieka (podmiot przestrzeni turystycznej, będący konsumentem-turystą, oraz organizatorem i zarządcą tej przestrzeni).

\subsubsection{KULTUROWA PRZESTRZEŃ TURYSTYCZNA}

Autor proponuje, $\mathrm{w}$ odniesieniu do analizy przestrzeni tanatoturystyki i próby jej konceptualizacji, typologię kulturowej przestrzeni turystycznej opartą na studium dystansu międzypokoleniowego M. MEAD (1978) (rys. 23).

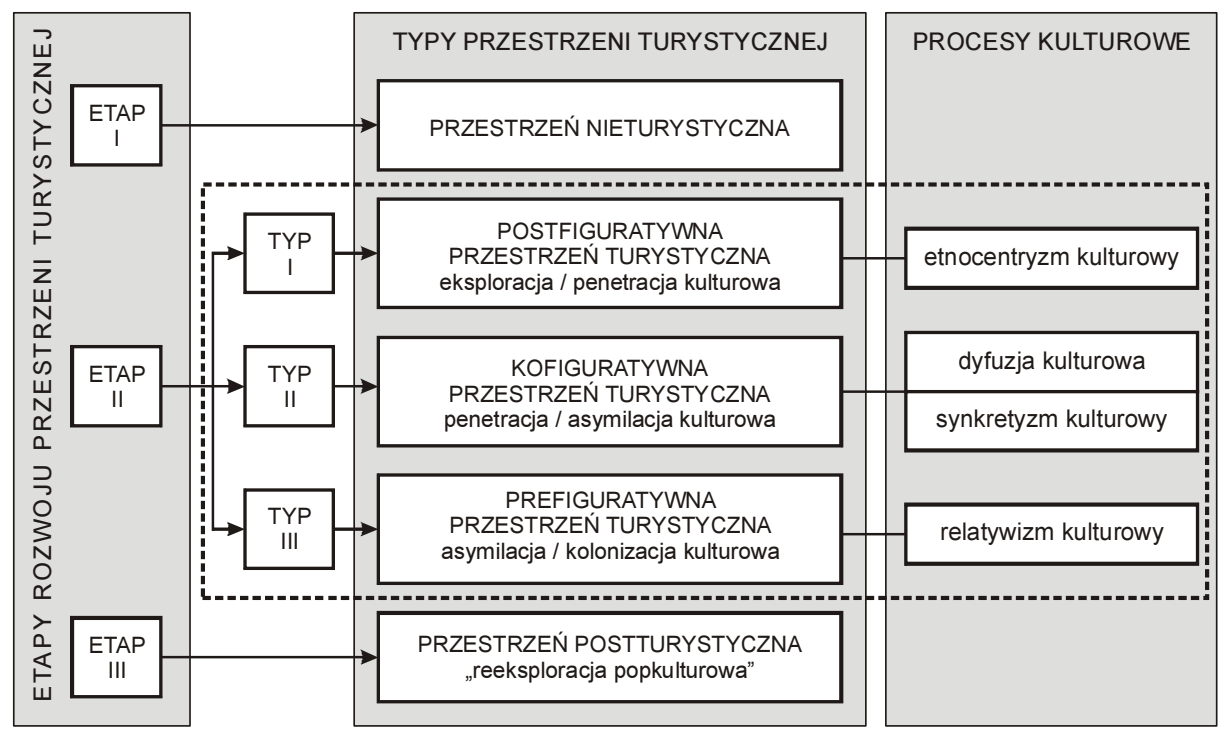

Rys. 23. Typologia kulturowej przestrzeni turystycznej

Źródło: opracowanie własne

Etap pierwszy: przestrzeń nieturystyczna - przestrzeń kulturowa pozbawiona funkcji turystycznych, brak ruchu turystycznego. Mogą to być przestrzenie jeszcze nieodkryte przez turystów lub izolowane. Powodem izolacji może być np. negatywna ocena analizowanej przestrzeni, determinowana etnocentryzmem, która nie pozwala na jej turystyczne wykorzystanie ze względów moralnych i etycznych. Fragment przestrzeni geograficznej poddany czynnikom zewnętrznym (moda, aktywność turystyczna, informacja) i wewnętrznym (dziedzictwo, propagowanie idei, religii, kultury) ze 
względu na specyficzne zasoby kulturowe zostaje w określonym czasie odkryty turystycznie i ulega przekształceniu w przestrzeń turystyczną. Przykładem są zapomniane obszary, na których odbywały się w historii tragiczne zdarzenia, historyczne cmentarze lub opuszczone obiekty poprzemysłowe. Przestrzenie te nie są odwiedzane turystycznie do czasu powiązania określonego faktu historycznego, społecznego lub przyrodniczego z konkretnym obszarem lub obiektem.

Etap drugi: przestrzeń turystyczna - przestrzeń kulturowa delimitowana geograficznie, w której rejestrowany jest ruch turystyczny (niezależnie od jego wielkości i charakteru). Przestrzeń ta ma cechy indywidualnej (osobistej) przestrzeni turystycznej i obszaru turystycznego. W zależności od etapu rozwoju zmiany w przestrzeni turystycznej zachodzące pod wpływem dyfuzji i synkretyzmu kultur kształtują nowe postawy i potrzeby turystyczne. $W$ zależności od cech uczestnika ruchu turystycznego możemy wyróżnić trzy typy kulturowej przestrzeni turystycznej:

Typ I to postfiguratywna przestrzeń turystyczna - przestrzeń turystyczna kształtowana przez mijające społeczeństwa tradycyjne. Sposób organizacji i percepcji zasobów kulturowych jest wspólny dla wszystkich, występuje bezwzględne uznanie tradycyjnego porządku przestrzeni kulturowej. Jest to zagospodarowana turystycznie przestrzeń, eksplorowana (odkrywana) lub penetrowana kulturowo, w której wiedza o przeszłości przekazywana jest przede wszystkim za pomocą autentycznej wizualizacji i narracji słownej. Przestrzeń turystyczna kształtowana jest na wzór utartego, tradycyjnego modelu przestrzeni turystycznej. Z braku konkurencyjnych wzorów zachowań turystycznych, w warunkach pewnej izolacji środowiskowej organizatorzy i zarządzający atrakcjami turystycznymi $\mathrm{z}$ reguły powielają sprawdzone schematy organizacji przestrzeni turystycznej. Jest to przestrzeń generująca tradycyjne podróże turystyczne, wartościowane etnocentrycznie.

W postfiguratywnej przestrzeni turystycznej występuje tradycyjna wizualizacja i narracja kultury śmierci. Przykładem są obiekty historyczne i sakralne, jak krypty katedry na Wawelu lub kościoła Paulinów na Skałce w Krakowie, historycznie identyfikowane z pamięcią narodową i patriotyzmem.

Typ II to kofiguratywna przestrzeń turystyczna - przestrzeń turystyczna kształtowana w społeczeństwach krajów rozwiniętych (przemysłowych), gdzie młoda i starsza generacja organizatorów i konsumentów przestrzeni kulturowej współpracuje na zasadach równorzędnych partnerów. W kofiguratywnej przestrzeni turystycznej tradycyjni kreatorzy przestrzeni turystycznych odgrywają podstawową rolę, określając formy i granice, w których organizacja przestrzeni turystycznej jest akceptowalna. Prekursorzy przestrzeni turystycznych nie są w stanie dostarczyć nowych wzorców organi- 
zacji tych przestrzeni zgodnych ze zmieniającymi się trendami kulturowymi. Nowi organizatorzy muszą znaleźć sposoby organizacji przestrzeni turystycznej podporządkowane oczekiwaniom młodych pokoleń. Kofiguratywna przestrzeń turystyczna jest charakterystyczna przede wszystkim dla społeczeństw przemysłowych i miejskich. Jej istota polega na wspólistnieniu kulturowych przestrzeni turystycznych młodej i starszej generacji. Dominuje turystyczna penetracja, z elementami kulturowej asymilacji (upowszechnianie i nabywanie wytworów kultury, podlegających dostosowaniu do odbiorcy), wynikająca z dyfuzji i synkretyzmu kultur. Przykładami będą obiekty muzealne, szlaki turystyczne, parki historyczne prezentujące artefakty kultury śmierci z wykorzystaniem nowoczesnych technologii prezentacji (Muzeum Powstania Warszawskiego) lub zagospodarowane turystycznie miejsca historycznie związane ze śmiercią, takie jak pola bitewne, szlaki wojenne itp. Treść przekazu i narracja są raczej podporządkowane historycznej autentyczności i kulturowej tradycji, ale upowszechniane w atrakcyjny sposób, docierający do masowego odbiorcy.

Typ III to prefiguratywna przestrzeń turystyczna - nowocześnie i multikulturowo zorganizowana przestrzeń turystyczna, w której występuje asymilacja i kolonizacja kulturowa (wartości kulturowe przenikają do kultur odmiennych, zakorzeniając się w nich, efektem czego jest akceptacja relatywizmu kulturowego). Organizatorzy tradycyjnych przestrzeni turystycznych, których forma zostaje uznana za „przestarzałą”, zmuszeni są do uznania niezależnych form nowych przestrzeni turystycznych organizowanych i konsumowanych przez młode pokolenie, ucząc się od nich nowych postaw i zachowań turystycznych. Nowe przestrzenie turystyczne są jeszcze w fazie początkowego rozwoju, nie są dobrze rozpoznane i trudno w pełni ocenić skutki społeczne, jakie generują.

Prefiguratywna przestrzeń turystyczna, która jest często nieautentyczna, to również przestrzeń ponowoczesna, narzucona i kształtowana przez masową i popularną kulturę. Przykładami są muzea horroru, obiekty rozrywkowe, wystawy ludzkich ciał, krypty grobowe i ossuaria, które zostały komercyjnie udostępnione turystom $\mathrm{w}$ celu realizacji potrzeb emocjonalnych. Przekaz historyczny i kulturowy może być zafałszowany, podporządkowany oczekiwaniom odbiorcy, ważna jest atrakcyjność formy przekazu.

Etap trzeci: przestrzeń postturystyczna - fragment przestrzeni geograficznej, w której ruch turystyczny został zahamowany ze względu na gwałtowne zdarzenie (kataklizm, katastrofę, upadek funkcji, zmiany polityczne, kulturowe). Przestrzeń, która nie pełni funkcji turystycznej z czasem zostanie odkryta na nowo, podlegać będzie reeksploracji turystycznej, czyli odkrywaniu przez turystę znanych wcześniej walorów, ale zapomnianych. Odkrywa- 
nie to następuje w zupełnie inny sposób, łamiący utarte schematy i normy. Można wręcz mówić o swego rodzaju "rewitalizacji” przestrzeni turystycznej. Za przestrzeń postturystyczną mogą służyć przestrzenie kulturowe, które interpretowane są $\mathrm{w}$ przewrotny sposób, np. zapomniane obiekty historyczne stanowiące tło dla funkcji rozrywkowych, handlowych czy usługowych, z zatarciem pamięci o ich pierwotnych funkcjach. Są to przestrzenie uznane za nieturystyczne, np. ze względu na zagrożenie życia, ograniczenia polityczne, kulturowe, stanowiące jednak cele indywidualnych podróży turystycznych (np. „miasta duchów”, opuszczone fabryki, zamknięte obszary). Przestrzeń postturystyczna to również ta, do której odbywają się wirtualne podróże bez opuszczania miejsca stałego zamieszkania, dzięki globalnej sieci Internetu (co przeczy współczesnym definicjom turystyki, zakładającym przemieszczanie się w przestrzeni geograficznej).

Zaproponowana typologia kulturowej przestrzeni turystycznej wraz z jej cyklem życia opisują sposoby narodzin, ewolucji i śmierci przestrzeni turystycznych uwarunkowanych zmianami pokoleniowymi i czynnikami społeczno-kulturowymi. Procesy decydujące o charakterze przestrzeni turystycznej mogą prowadzić do jej degradacji (,śmierci"), powodując upadek funkcji lub restrukturyzację (odrodzenie) i wywołując zazwyczaj pożądane zmiany (WŁODARCZYK 2009, s. 103).

Przestrzeń tanatoturystyki można uznać za przestrzeń zarówno postfiguratywną (gdy jest interpretowana jako przestrzeń sacrum), kofiguratywną (gdy jest przestrzenią traktowaną i jako sacrum, i jako profanum) oraz prefiguratywną (gdy zdecydowanie będzie przestrzenią profanum). Przyporządkowanie typu przestrzeni turystycznej do konkretnych fragmentów przestrzeni geograficznych uzależnione będzie od sposobu jej organizacji oraz indywidualnej interpretacji.

\subsubsection{PRZESTRZEŃ TANATOTURYSTYKI}

Przestrzeń śmierci wykorzystywana $\mathrm{w}$ turystyce definiuje charakter wykształconej przestrzeni turystycznej. Autor, opierając się na opracowaniu B. WŁODARCZYKA (2009, s. 80-82) uważa, że przestrzeń, w której człowiek (turysta) percypuje wartości związane ze śmiercią, jest przestrzenią turystyczną człowieka odbieraną i interpretowaną bardzo indywidualnie, będącą sumą miejsc (obszarów) odwiedzanych przez konkretnego turystę. Dlatego charakter tej przestrzeni i jej delimitacja nie musi być tylko obiektywna, ale może być również subiektywna (mentalna), niepodlegająca warunkom, jakie spełnia przestrzeń turystyczna obszaru będąca zbiorem miejsc (obszarów) i procesów w nich zachodzących. 
Tak więc turystyczna przestrzeń śmierci (przestrzeń tanatoturystyki) jest przestrzenią postrzeganą indywidualnie (jest subiektywna, będąca swoistym wyobrażeniem powstającym na podstawie wcześniejszych doświadczeń). Może być zarówno przestrzenią wyobrażeń, przestrzenią realną, jak i przestrzenią o ograniczonej dostępności (LISZEWSKI 2005, 2006, WŁODARCZYK 2009). Przestrzeń śmierci może być także indywidualną przestrzenią niepostrzeganą, niechcianą, nieakceptowaną, najczęściej z uwagi na czynniki kulturowe, wówczas nie będzie traktowana jako przestrzeń turystyczna (rys. 24).

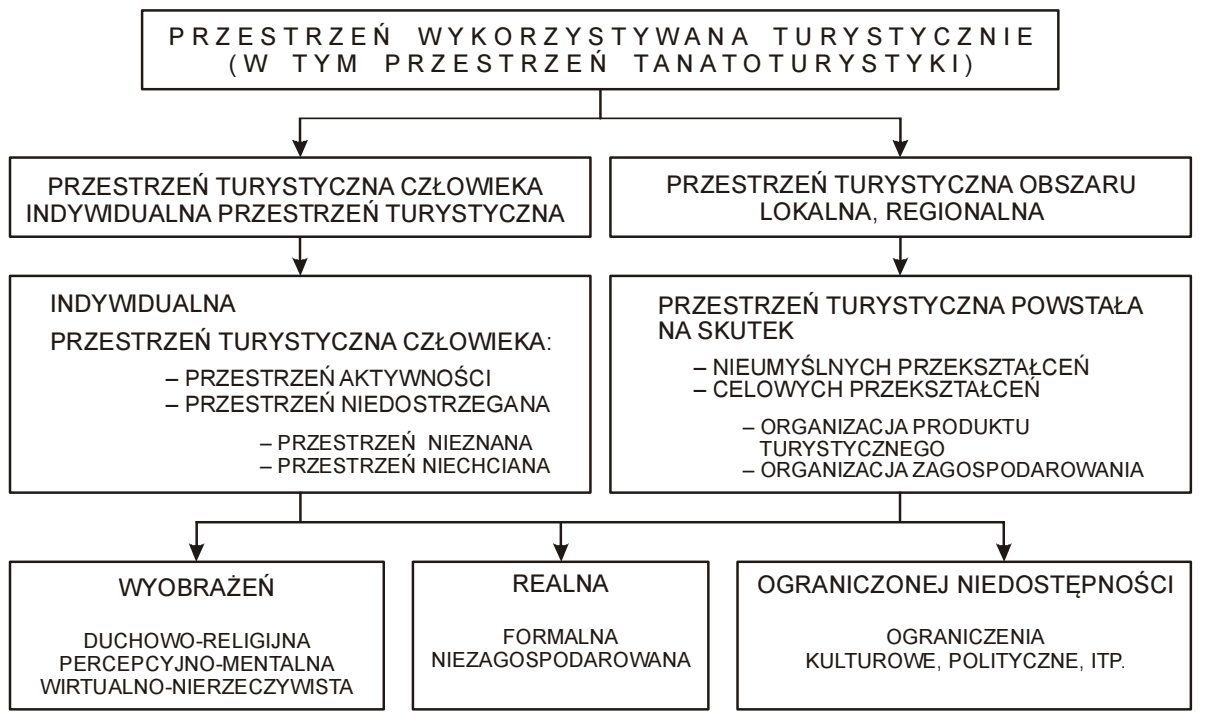

Rys. 24. Przestrzeń tanatoturystyki z perspektywy człowieka i obszaru Źródło: na podstawie S. LISZEWSKIEGO (2006) i B. WŁODARCZYKA (2009)

Przestrzeń wyobrażeń, którą S. LISZEWSKI (2006) podzielił na duchoworeligijną, percepcyjno-mentalną i wirtualno-rzeczywistą, jest stosunkowo często kreowana $\mathrm{w}$ ramach przestrzeni tanatoturystyki. Duchowo-religijną przestrzenią tanatoturystyki będzie każda przestrzeń śmierci mająca wymiar sacrum, gromadząca mogiły, relikwie świętych, upamiętniająca męczeństwo itp. Przestrzeń ta zazwyczaj nie ma formalnych granic. Jest wyrazem systemu wartości człowieka, jego tożsamości. Percepcyjno-mentalną przestrzenią tanatoturystyki może być każda nekropolia, która będzie postrzegana jako atrakcja turystyczna. Wirtualno-nierzeczywistą przestrzenią tanatoturystyki będzie przestrzeń, która albo gromadzi zbiór artefaktów i działań ludzkich nawiązujących do emocjonalnego aspektu śmierci (strachu, odrazy, zabawy), albo jest przestrzenią potencjalnie stwarzającą realne zagrożenie życia, bazują- 


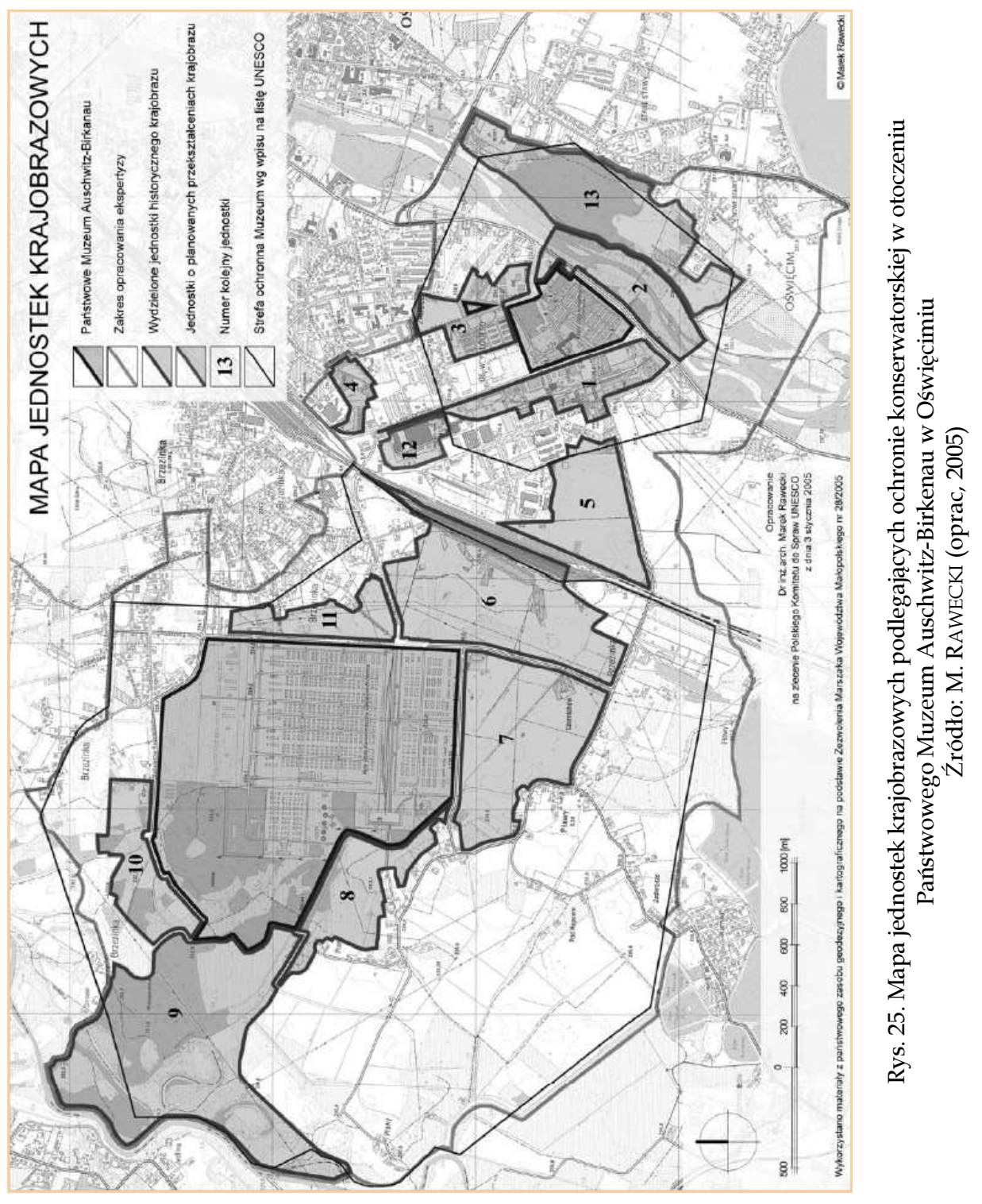


cą na wyobrażeniach opartych m.in. na przekazie historycznym przekształconym na potrzeby komercyjnego produktu. Przykładami przestrzeni wirtualno-nierzeczywistych będą muzea śmierci, horroru, miejsca niebezpieczne, miejsca katastrof, morderstw, aktów przemocy, determinując poprzez odpowiednie zagospodarowanie rozwój przestrzeni turystycznej.

Do realnej przestrzeni tanatoturystyki (formalnej lub niezagospodarowanej) będą należały atrakcje turystyczne oparte na historycznym dziedzictwie - np. na terenie dawnej wsi Czermna (dziś część Kudowy Zdrój) znajduje się Kaplica Czaszek, która jest atrakcją turystyczną determinującą rozwój lokalnego zagospodarowania turystycznego. Innym przykładem realnej przestrzeni tanatoturystyki jest przestrzeń Państwowego Muzeum Auschwitz-Birkenau w Oświęcimiu i jego otoczenia, podlegająca ochronie konserwatorskiej, a obejmująca znacznie większy obszar niż teren samego muzeum (rys. 25).

Przykładem niezagospodarowanej przestrzeni tanatoturystyki są np. pola bitewne lub zapomniane cmentarze i mogily wojenne. Przestrzeniami o ograniczonej dostępności będą przestrzenie bardzo rzadko wykorzystywane na potrzeby tanatoturystyki, m.in. ze względu na ograniczenia kulturowe lub polityczne (np. miejsca rytualne związane z ceremoniami pogrzebowymi lub miejsca ograniczone przez instytucje polityczne, takie jak obszary konfliktów zbrojnych i niebezpieczne dla życia).

\subsubsection{DETERMINANTY ROZWOJU PRZESTRZENI TANATOTURYSTYKI}

Rozwój turystyki i przestrzeni turystycznej uwarunkowany jest wieloma zmiennymi. Należą do nich m.in. determinanty, a więc „elementy (czynniki), których funkcja polega na wyznaczaniu (determinowaniu - określaniu, wyznaczaniu) czegoś" (SZYMCZAK, red. 1982). Determinanty można podzielić na wewnętrzne (endogeniczne), wynikające z właściwości opisywanego zjawiska lub przestrzeni, oraz na egzogeniczne (zewnętrzne), niewynikające z ich właściwości.

B. WŁODARCZYK (2009, s. 140), dokonując klasyfikacji i charakterystyki determinant rozwoju przestrzeni turystycznej, wyróżnił dwie zasadnicze grupy:

1) determinanty właściwe, do których zaliczyć można:

a) stymulatory - będące impulsem pobudzającym podejmowanie aktywności turystycznej oraz działanie na rzecz turystyki,

b) bariery - będące przeszkodą uniemożliwiającą lub ograniczającą aktywność turystyczną i rozwój przestrzeni turystycznej;

2) katalizatory obejmujące: 
a) aktywatory - wspomagające i przyśpieszające oddziaływanie determinant właściwych,

b) inhibitory - spowalniające lub ograniczające działanie determinant właściwych.

Cechą katalizatorów występujących samodzielnie jest niewielki ich wpływ na rozwój i charakter przestrzeni turystycznej. Ich działanie jest widoczne, gdy występują wspólnie z którąś z determinant właściwych. Przykładami katalizatorów są media i reklama, które przez przekaz informacyjny i promocyjny wpływają na zachowania turystów, inwestorów lub lokalnych społeczności.

Moc oddziaływania determinant jest uzależniona od czasu, w którym je obserwujemy oraz od zróżnicowania geograficznego (kulturowego, fizjograficznego, klimatycznego). B. WŁODARCZYK (2009, s. 141) wyróżnia:

a) determinanty ciągłe - występujące stale, nie podlegają gwałtownym zmianom; mogą nimi być: historyczne dziedzictwo kulturowe, bariery kulturowe, izolacja geograficzna;

b) determinanty okresowe - występujące cyklicznie, mają wpływ na zmiany stanu i charakteru przestrzeni turystycznej w długim okresie, jak np. determinanty występujące $\mathrm{z}$ różnym natężeniem i w różnych przedziałach czasowych; determinanty okresowe mają wplyw na ewolucję przestrzeni turystycznej i jej fazy; mogą to być działania wojenne, masowa lub indywidualna śmierć, zmiany polityczne i kulturowe itd.;

c) determinanty incydentalne - występujące jednorazowo (powtarzalnie lub nie) w stosunkowo krótkim czasie; zmiany wynikające $\mathrm{z}$ występowania tych czynników mogą mieć charakter gwałtowny i krańcowy (zmiana fazy rozwoju przestrzeni turystycznej); mogą to być akty przemocy, terrorystyczne, kataklizmy, wyjątkowa w swym charakterze masowa i indywidualna śmierć.

W przypadku kształtowania się funkcji turystycznej przestrzeni śmierci istotne są wszystkie trzy grupy determinant.

Determinanty ciągłe mają przede wszystkim charakter kulturowy. W długim okresie gromadzone są wytwory kultury i obowiązują ustalone normy oraz tradycje kulturowe determinujące sposób postrzegania i interpretacji śmierci, a także śmiertelności. Są to m.in. religia, światopogląd, moralność, uwarunkowania geograficzne, takie jak klimat, ukształtowanie powierzchni, biosfera. Kultura jest determinowana czynnikami przyrodniczymi i geograficznymi, a ich zróżnicowanie ma odzwierciedlenie $\mathrm{w}$ różnorodności rytuałów, wierzeń, ekspresji i norm społecznych określających miejsce śmierci i zmarłego w życiu człowieka. Determinanty okresowe i incydentalne wy- 
stępują w cyklach lub jednorazowo wpływają na stopniowe przekształcanie przestrzeni nieturystycznych (np. przestrzeni śmierci) w przestrzenie o charakterze turystycznym. Akty gwałtownej śmierci lub śmierci indywidualnej człowieka, ale również zwierząt, roślin, a nawet przestrzeni, poddane są pewnej powtarzalności, cyklom (w kulturze hinduskiej i buddyjskiej cykl kołowrót - narodzin i śmierci określa się terminem samsara). Cykliczne zmiany polityczne, kulturowe i społeczne mają wpływ na nową organizację przestrzeni, determinowaną wewnętrznymi i zewnętrznymi czynnikami. Czynniki determinujące śmierć (kres życia) decydują o narodzinach przestrzeni śmierci, która pod wpływem pamięci i ruchu turystycznego może przejść w turystyczną przestrzeń śmierci (przestrzeń tanatoturystyki). Przestrzeń ta nacechowana kresem, końcem kogoś lub czegoś, staje się początkiem turystycznej przestrzeni życia odwiedzanej przez turystów i pielgrzymów, zrewitalizowanej i zagospodarowywanej na nowo. Przykładem są miejsca reprezentujące kres życia $\mathrm{w}$ najrozmaitszym wymiarze. $\mathrm{Z}$ czasem $\mathrm{w}$ ramach przestrzeni śmierci kształtuje się przestrzeń pamięci powstająca $w$ wyniku procesu upamiętniania lub rewitalizacji, która pod wpływem ruchu turystycznego stanie się przestrzenią turystyczną, tym samym nową przestrzenią życia (rys. 26).

W zależności od charakteru i natężenia determinant (stymulatorów i barier) oraz zastosowania określonych katalizatorów (np. informacji), na podstawie opracowania B. WŁODARCZYKA (2009, s. 142), można wyróżnić:

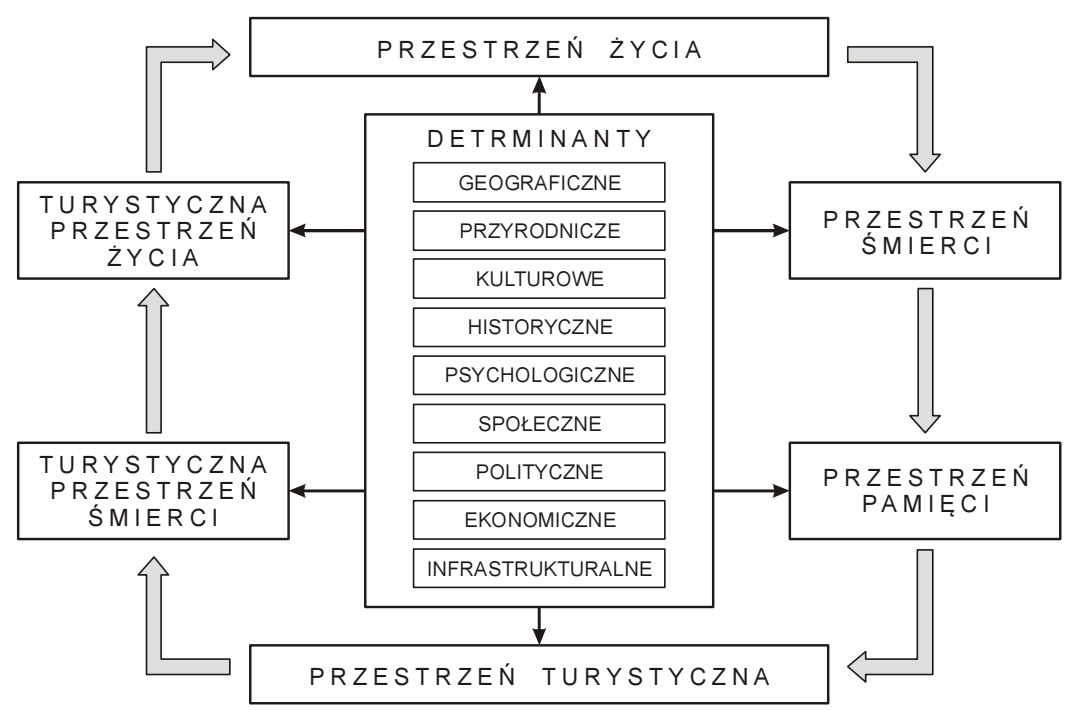

Rys. 26. Wpływ determinant na samsarę przestrzeni życia i śmierci Źródło: opracowanie własne 
- turystyczne przestrzenie ograniczone, w których bariery i inhibitory przeważają; do takich przestrzeni należą początkowo przestrzenie śmierci, czasem przestrzenie pamięci i przestrzenie życia;

- turystyczne przestrzenie otwarte, w których przeważają stymulatory i aktywatory; mogą to być przestrzenie nowego życia, przestrzenie turystyczne i turystyczne przestrzenie śmierci (tanatoturystyki).

$\mathrm{W}$ kształtowaniu przestrzeni tanatoturystyki $\mathrm{w}$ grupie wymienionych determinant mają znaczenie:

1) determinanty geograficzne - czynniki zróżnicowane przestrzennie, takie jak stopień urbanizacji i uprzemysłowienia (lokalizacja i charakter cmentarzy, rewitalizacja przestrzeni), wysokość nad poziomem morza i rzeźba terenu (determinująca charakter kultury, wierzeń, rytuału), rozmieszczenie siedlisk ludzkich, wpływ człowieka na przekształcenia na powierzchni Ziemi;

2) determinanty przyrodnicze - czynniki klimatyczne (sposób postępowania ze zmarlymi, susze i powodzie), kataklizmy (erupcje wulkanów, tsunami, trzęsienia ziemi, huragany);

3) determinanty kulturowe - wytwory kultury materialnej i niematerialnej (religie, rytuały, obrzędy, artefakty, wydarzenia), percepcja śmierci (tabu śmierci, pornografia śmierci, śmierć oswojona);

4) determinanty historyczne - dziedzictwo historyczne, znaczenie pamięci historycznej, martyrologia, działania na rzecz upamiętnienia ludzi, wydarzeń, przestrzeni;

5) determinanty psychologiczne - percepcja przestrzeni, wiedza, interpretacja przestrzeni śmierci, stereotypy, świadomość;

6) determinanty społeczne - charakter społeczności lokalnej i turystów, wiek, wykształcenie, charakter życia społecznego, więzi międzyludzkie, tolerancja, otwartość, bierność, niechęć wobec innych modeli życia, organizacji przestrzeni życia;

7) determinanty polityczne - działania podejmowane przez władze państwowe i samorządowe, prawo, historia polityczna, znaczenie polityki w życiu społecznym, zakazy i nakazy;

8) determinanty ekonomiczne - udostępnienie lub niedostępność dla funkcji turystycznych, religijnych, rozrywkowych, udogodnienia dla producentów usług turystycznych, obsługi odwiedzających, potrzeby ekonomiczne warunkujące przekształcenie przestrzeni nieturystycznej w turystyczną;

9) determinanty infrastrukturalne - optymalne zagospodarowanie przestrzeni śmierci, infrastruktura, dostępność komunikacyjna, ograniczenia lub udogodnienia w ruchu turystycznym i pielgrzymkowym. 
Zarówno stymulatory, jak i bariery rozwoju przestrzeni tanatoturystyki są zróżnicowane w zależności od obszaru kulturowego. Do stymulatorów rozwoju przestrzeni tanatoturystyki zaliczymy:

- dziedzictwo kulturowe w postaci artefaktów kultury śmierci, obrzędów i wierzeń; pamięć historyczną;

- zagospodarowanie i infrastrukturę ułatwiające dostęp do wytworów kultury śmierci (np. szlaki, informacja, obsługa);

- działalność marketingową zwiększającą atrakcyjność odwiedzanej przestrzeni (np. pamiątki, wizualizacja, teatralizacja, promocja);

- organizację i zarządzanie umożliwiające funkcjonowanie przestrzeni w określonych realiach społeczno-gospodarczych.

Przestrzeń tanatoturystyki ze względu na swoją specyfikę obciążona jest wieloma barierami rozwoju, do których zaliczyć można czynniki hamujące:

- ograniczenia społeczne: moralne, etyczne, religijne, prawne i polityczne;

- warunki techniczne, logistyczne i infrastrukturalne;

- stopień bezpieczeństwa;

- warunki przyrodnicze i geograficzne.

\subsection{EDUKACJA W PRZESTRZENI TANATOTURYSTYKI ${ }^{7}$}

$\mathrm{Z}$ perspektywy pedagogiki turystyka ma istotne walory wychowawcze. Nie bez przyczyny powiedzenie "podróże kształcą" jest jednym z najbardziej popularnych haseł zachęcających do uprawiania turystyki poznawczej. Turystyka ma lub może mieć wpływ na sposób, w jaki człowiek określa swój stosunek do śmierci, pod warunkiem, że przedmiotem zainteresowania turystycznego będzie przestrzeń śmierci w ramach turystyki religijnej, edukacyjnej, krajoznawczej i rozrywkowej.

\subsubsection{PRZESTRZEŃ PAMIĘCI}

Przestrzeń kulturowa jest m.in. obszarem nagromadzenia elementów dziedzictwa kulturowego i historycznego będących przedmiotem zainteresowań

${ }^{7}$ Fragmenty rozdziału zostały zaprezentowane przez autora w artykułach: Znaczenie pamięci w przestrzeni turystycznej miasta, [w:] B. Włodarczyk (red.), Turystyka. Księga jubileuszowa w 70. rocznice urodzin Profesora Stanistawa Liszewskiego, Wydawnictwo UŁ, Łódź 2011, s. 121-133; Edukacyjne i wychowawcze aspekty tanatoturystyki, [w:] Z. Rudnicki (red.), Ars moriendi, ars vivendi, ars educandi, Wydawnictwo Naukowe UAM, Poznań 2012, s. 427-442. 
poznawczych. Warto pamiętać, że kultury nie można rozpatrywać wyłącznie w sferze przedmiotowej (wytworów człowieka), ale również w sferze treści i wzorów wartości, idei i symbolicznie znaczących systemów kształtujących ludzkie zachowania. Wobec tego dziedzictwo kulturowe można rozumieć jako ogół dorobku kulturowego, materialnego i duchowego odziedziczonego po przodkach. Dziedzictwo historyczne to ogół zgromadzonej wiedzy na temat przeszłości utrwalonej w przestrzeni, spisanej, zarejestrowanej lub pozostającej w pamięci ludzkiej. Materialne elementy dziedzictwa historycznego i kulturowego składają się na krajobraz kulturowy i stanowią o istocie przestrzeni pamięci.

Przestrzeń śmierci wraz z krajobrazem śmierci są jednocześnie przestrzenią i krajobrazem pamięci. Pamięć o procesach i zdarzeniach w zmieniających się konfiguracjach historycznych, o ludziach - swiadkach tych procesów, i o faktach lokalnej przeszłości, zwiększa poczucie osadzenia w ojczystej historii, wzmacnia emocjonalne więzi niezbędne do kształtowania dalszych losów społeczności, dla których dziedzictwo przeszłości stanowi grunt do budowania oczekiwań przyszłości.

Szczególnie na obszarach miast i wsi obserwujemy ścieranie się sił społecznych, próbujących bronić tożsamości społeczno-kulturowej własnych „małych ojczyzn”, z siłami działającymi na tym obszarze dla własnych, prywatnych lub wąsko pojmowanych partykularnych interesów. Aby przeciwdziałać negatywnym siłom dezintegrującym dziedzictwo należy zadbać o odpowiednie zagospodarowanie przestrzeni pamięci zarówno na potrzeby mieszkańców, jak i turystów. Obszar zamieszkany, poszczególne jego fragmenty są nośnikami wartości ważnych dla jego mieszkańców. Ze względu na osobisty stosunek i obdarzenie emocjami miejsca identyfikowane pamięcią stają się "miejscami własnymi”. Są wartościami, które sprzyjają budowaniu więzi "małej ojczyzny". Jako miejsca przechowujące pamięć stają się naturalnym przekaźnikiem lokalnych kultur i tradycji (KŁOSEK-KOZŁOWSKA 2002). Należy pamiętać jednak, że są obszary, które stanowią sacrum nie tylko dla jego mieszkańców, ale są również dziedzictwem ogólnonarodowym. Za przykład może posłużyć Wzgórze Wawelskie, które jest nie tylko przestrzenią pamięci Krakowa, ale również pamięci narodowej Polaków.

W jaki sposób dziedzictwo śmierci jest eksponowane w przestrzeni geograficznej? Jak funkcjonuje i jakie formy przyjmuje $\mathrm{w}$ tej przestrzeni pamięć o przodkach, wydarzeniach i miejscach? Kto jest odbiorcą przestrzeni pamięci? Poszukując odpowiedzi na postawione pytania autor posłużył się przykładem przestrzeni pamięci miasta.

W każdym mieście można odnaleźć symbolikę świadczącą o pielęgnowaniu pamięci historycznej wyrażanej m.in. w formie pomników i tablic pa- 
miątkowych, muzeów czy uroczystości i inscenizacji upamiętniających wydarzenia z przeszłości. $W$ przestrzeni miasta znajdziemy również obiekty, miejsca, wydarzenia i postawy społeczne świadczące o jego specyfice kulturowej. Turystyka historyczna, kulturowa i krajoznawcza nie może istnieć bez wykorzystania pamięci, bez zaznaczenia tej pamięci w sposób symboliczny i trwały w przestrzeni geograficznej. Można sformułować tezę, że miasto będące antropogenicznie ukształtowaną jednostką osadniczą ma własną pamięć zapisaną materialnie $\mathrm{w}$ przestrzeni lub zachowaną w pamięci mieszkańców. Miasto składa się z wyobrażeń i rzeczywistości, jest „pisane” i jest „czytane”.

Mieszkaniec lub turysta podczas swoich poznawczych wędrówek oczekuje kontaktu z autentyczną przestrzenią, z materialnymi pozostałościami świadczącymi o historii określonego miejsca lub człowieka, czyli z tym wszystkim, co „było" lub „jest” i ma swoją historię. Im bardziej komunikatywnie historia jest przekazana, tym łatwiej zostanie zrozumiana i zinterpretowana. Istotnym przedmiotem poznania są wytwory kultury materialnej i niematerialnej pozostające $\mathrm{w}$ tej przestrzeni, najczęściej zgromadzone w muzeach, zlokalizowane na określonych obszarach lub wyrażane przez zachowania społeczne, język, tradycje czy ubiór.

Pamięć można zdefiniować jako „wspomnienie, pamiątkę, upamiętnienie kogoś lub czegoś" (DUBISZ, red. 2003), a więc przestrzenią pamięci będzie wyodrębniony obszar z przestrzeni geograficznej, w której zachowuje się wspomnienie, upamiętnia się kogoś lub coś. Czy można mówić o modelu miejsca pamięci? Z pewnością model miejsca pamięci jest efektem "prawa własności" do pamięci - ten, kto „dysponuje” pamięcią, decyduje o sposobie wyrażenia jej w przestrzeni geograficznej, co może stanowić przedmiot sporów. Symbolika pamięci miejskiej ma niewątpliwie wpływ na spójność miasta. Istotnym obszarem tej spójności jest przestrzeń publiczna stanowiąca o wartości krajobrazowej miasta. Należy pamiętać, że przestrzeń pamięci może znajdować się również w obrębie przestrzeni zamkniętej (niepublicznej, prywatnej).

W przestrzeni miasta główną rolę w kształtowaniu pamięci odgrywają obiekty architektoniczne, pomniki, obiekty muzealne, cmentarze i zieleń miejska, układ urbanistyczny, mała architektura, toponimia, wydarzenia i wszystkie te elementy, które niosą ze sobą przekaz o przeszłości. Nie każda rzeźba, kamienica czy nazwa ulicy może zostać uznana za składową przestrzeni pamięci. Będą to elementy przestrzeni miejskiej, które upamiętniają, a nie tylko symbolizują. Trudno uznać np. rzeźbę artystyczną w parku która sklasyfikowana zostanie jako pomnik - za składową przestrzeni pamięci miasta, jeżeli ma jedynie wartości estetyczne, bez związku z lokalną historią i kulturą. Jednak obiekty i miejsca wraz z upływającym czasem mo- 
gą zostać włączone w przestrzeń pamięci. Architektoniczna forma współczesnego miasta powstaje bowiem $\mathrm{w}$ rezultacie nakładania się na siebie wielu tradycji historycznych, odzwierciedla przemiany spoleczne i kulturowe. Jednym z założeń kształtowania przestrzeni miasta jest jego spójność w czasie - rozumiana jako historyczna ciągłość tożsamości w czasie, i społeczna wyrażająca się m.in. równowagą i zaangażowaniem społecznym, wielokulturowym bogactwem, utrzymywaniem związków międzypokoleniowych, dbałością o własny charakter społeczny i kulturowy przestrzeni miasta (DREWNIAK, SZUBA 2007).

Przestrzeń pamięci miasta jest zróżnicowana i niejednorodna, uzależniona od wielu czynników zarówno wewnętrznych, jak i zewnętrznych, mających wpływ na dokonujące się przemiany przestrzeni miejskiej. Rysunek 27 przedstawia zasoby miejskiej przestrzeni pamięci historycznej i kulturowej, które można podzielić na dwie zasadnicze grupy, elementy materialne mające odzwierciedlenie $\mathrm{w}$ przestrzeni, i niematerialne - wpływające na tożsamość przestrzeni miejskiej.

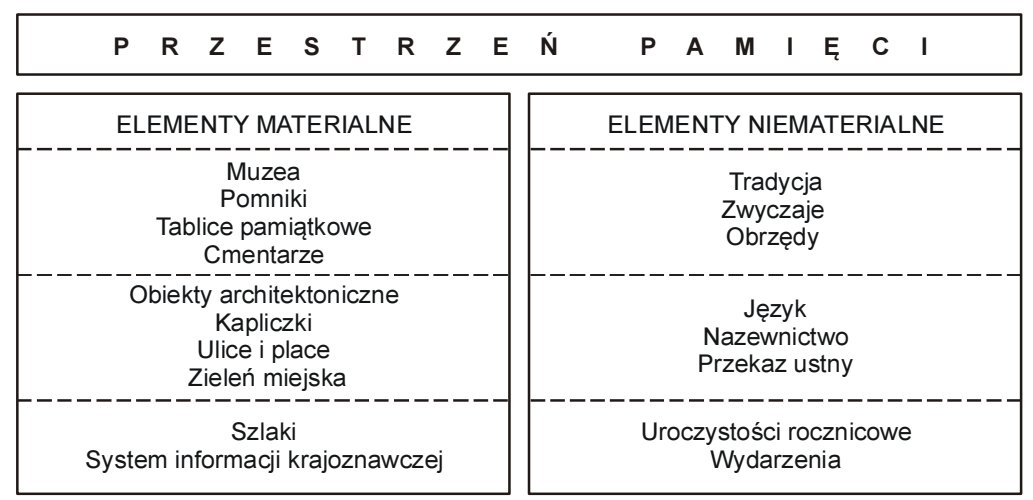

Rys. 27. Elementy przestrzeni pamięci miasta Źródło: S. TANAŚ (2011b)

Do grupy elementów materialnych przestrzeni pamięci należy zaliczyć obiekty, które powstają zwykle w celu podtrzymania pamięci, np. muzea, pomniki, tablice pamiątkowe i cmentarze. Ponadto wyróżnić należy składowe, które pośrednio stanowią przestrzeń pamięci, a ich geneza nie jest stricte memoratywna (obiekty architektoniczne, kapliczki, ulice, place), oraz elementy wspomagające pamięć o miejscu, wydarzeniu czy człowieku, jakim będzie np. szlak wspierany systemem informacji krajoznawczej (turystycznej).

Grupa elementów niematerialnych obejmuje dziedzictwo duchowe, do którego można zaliczyć tradycje, zwyczaje, obrzędy oraz język, toponimię 
(nazewnictwo) i przekaz słowny. Nieco inny charakter mają wydarzenia upamiętniające fakty historyczne i uroczystości rocznicowe, wpisane na stałe w kalendarz uroczystości miejskich.

Miejscami najbardziej intensywnych i owocnych poszukiwań dowodów pamięci są muzea, choć nie zawsze muzeum jest miejscem pamięci. Muzea i pomniki dokumentujące tragiczne wydarzenia mogą budzić kontrowersje wskutek odmiennej oceny historycznej, jak np. w Polsce pomniki pamięci żołnierzy Armii Czerwonej. Miejsca pamięci mają za zadanie wypełniać puste miejsca w zbiorowej świadomości społecznej, czego wyrazem są pomniki zbiorowych egzekucji.

Muzea pełniące funkcję miejsca pamięci poddane są określonym uwarunkowaniom i ograniczeniom uwzględniającym np. funkcje i parametry techniczne obiektu czy związek formy budynku z ekspozycją, określających charakter muzeum. Muzea historyczne lokalizowane m.in. w budynkach pofabrycznych pełnią funkcję miejsc koncentrujących "złą" i "dobrą" pamięć. Lokowane są niejednokrotnie w budynkach uchronionych przed wyburzeniem, dzięki rewitalizacji i zmianie funkcji. Jednym $\mathrm{z}$ najlepszych polskich przykładów muzeum historycznego jest zlokalizowane $\mathrm{w}$ budynku dawnej fabryki Muzeum Powstania Warszawskiego, prezentujące pamięć $\mathrm{o}$ „złym" czasie. Muzeum jako obiekt będący nośnikiem pamięci jest powszechnym narzędziem kształtowania polityki pamięci (KABROŃSKA 2008).

Pomnik definiowany jest jako „dzieło architektoniczno-rzeźbiarskie, wznoszone $\mathrm{w}$ formie posagu, obelisku, płyty czy budowli, ku czci jakiejś osoby lub dla upamiętnienia jakiegoś wydarzenia" (DuBISZ, red. 2003). Specyficzną formą pomnika jest nagrobek. Pomnik odwołuje się do symboliki, jest elementem szaty informacyjnej o historii miejsca. Do tej szaty należą również tablice upamiętniające wydarzenia i ludzi. Współczesne funkcje pomników są wieloaspektowe. Uzupełniają przestrzeń publiczną, materializują pamięć, kształtują tożsamość mieszkańców miasta, są narzędziem walki ideologicznej w przestrzeni publicznej. Pomnik, podobnie jak budynek czy nazwa ulicy, może zostać usunięty z przestrzeni publicznej, jest więc nietrwałym sposobem upamiętniania historii.

Pomniki można skategoryzować według różnych kryteriów. W zależności od przedmiotu upamiętnienia możemy wyróżnić m.in. pomniki wojenne, martyrologiczne, bohaterów indywidualnych i zbiorowych, postaci historycznych, artystów, uczonych, lokalnych osobistości, postaci literackich i fikcyjnych, zwierząt $i$ inne. Ze względu na formę dzielimy pomniki na: monumentalne, figuralne, popiersia, kamienie pamiątkowe i pomniki nietypowe (KAZIMIERCZAK 2009). 
W Polsce po II wojnie światowej pomniki odgrywały znaczącą rolę w kształtowaniu postaw ideologicznych oraz utrwalaniu pamięci martyrologicznej. Dopiero trzy ostatnie dekady XX wieku przyniosły zmiany w definiowaniu pomnika, który zaczął pełnić funkcję upamiętniającą nie tylko wydarzenia historyczne, ale również inne, często związane z kulturą popularną (postaci filmowe, artystów, zwierzęta). Pomnik może podnieść lub obniżyć rangę miejsca, niekoniecznie musi wiązać się z miejscem historycznie.

Poza pomnikami w przestrzeni miasta powszechne są tablice pamiątkowe i wotywne, epitafia lub kapliczki. Tablica pamiątkowa to „płyta wykonana z drewna, wykuta z kamienia lub odlana $\mathrm{z}$ metalu, pokryta odpowiednią inskrypcją, upamiętniająca doniosłe wydarzenie lub zasłużoną osobistość" (SZOLGINIA 1982). Stosunkowo rzadko tablica pamiątkowa traktowana jest jako walor poznawczy (turystyczny). Najczęściej odkrywana jest podczas uroczystości rocznicowych, bywa nietrwale umocowana $\mathrm{w}$ świadomości ludzkiej.

Szczególne znaczenie dla dziedzictwa historycznego i kulturowego, dla zachowania i przekazania następnym pokoleniom świadectwa historii, źródeł i dokumentów mają cmentarze. Niejednokrotnie są cennym zabytkiem architektonicznym, na który składają się rzeźby, pomniki, nagrobki, grobowce i kaplice świadczące o cechach i pochodzeniu zmarlego oraz o okresie, w którym powstały. Przestrzeń cmentarza zawiera istotny pierwiastek estetyczny, na który składa się architektura krajobrazu tworząca tożsamość nekropolii. Wraz z rozwojem cmentarzy pojawiały się formy zdobnictwa grobów (sarkofagi, epitafia), rozkwitała sztuka grobowa, zwana sepulkralną, charakteryzująca się różnymi formami nagrobków i specyficznym zdobieniem symbolicznym. Przestrzeń sepulkralna generuje wartości historyczne i krajoznawcze, takie jak architekturę, sztukę, słowo pisane, oprawę roślinną. Jest wytworem pracy ludzkiej i stanowi istotny element dziedzictwa lokalnej społeczności.

Cmentarz jest pewnym fragmentem przestrzeni miejskiej, w ramach którego realizowana jest przez określoną społeczność praktyka grzebania zmarłych odpowiadająca wyznaniowym, etniczno-kulturowym i innym potrzebom danej społeczności. Wobec tego za najważniejszą cechę cmentarza należy uznać jego znakową rozpoznawalność. Nekropolie są efektem realizacji potrzeb kulturowych wyższego rzędu, $\mathrm{z}$ tego względu mają istotne znaczenie $\mathrm{w}$ zaspokajaniu potrzeb poznawczych związanych $\mathrm{z}$ kulturą $\mathrm{i}$ historią. Walorem poznawczym cmentarza jest $\mathrm{w}$ rzeczywistości jego infrastruktura stanowiąca o jego charakterze. Można wręcz wysunąć tezę, że wzmacnia on więzi ludzkie, budując tożsamość kulturową miasta. 
Zabytkowe obiekty architektoniczne świadczą o sposobie kształtowania przestrzeni miejskiej w przeszłości i stanowią istotną składową przestrzeni pamięci. Obiekty architektoniczne są opisywane w przewodnikach i folderach turystycznych, są istotnymi elementami szlaków tematycznych i historycznych. Niestety, są również przykładem braku ciągłości pamięci, wielokrotnie wraz z upływającym czasem tracąc swą historyczną tożsamość, której podtrzymanie ogranicza się do lakonicznej informacji krajoznawczej.

Toponimia miejska jest także istotnym elementem przestrzeni pamięci miejskiej. Nazwy ulic, placów, skwerów, dzielnic miasta przypominają o historii ludzi, wydarzeń i miejsc bezpośrednio lub pośrednio związanych $\mathrm{z}$ miastem. Toponimia zachowuje ślady historyczno-topograficznego obrazu przestrzeni, w której założono miasto, dokumentuje działalność człowieka i fakty historyczne. Jednocześnie nazewnictwo ulega następującym zmianom w zależności od decyzji aktualnego „właściciela” przestrzeni.

Przestrzeń pamięci podlega procesom konsolidacji, która polega m.in. na organizowaniu szlaków tematycznych, historycznych, pamięci, łączących odległe od siebie miejsca historyczne i cząstkowe przestrzenie pamięci. Organizacja szlaków może stać się impulsem do odnowienia pamięci o zapomnianym miejscu lub obiekcie, istotnym z perspektywy geograficznej, historycznej czy kulturowej. Turystyczną wartość szlaku zwiększa zawsze system informacji krajoznawczej (turystycznej).

Odmienną grupą kształtującą przestrzeń pamięci są jej elementy niematerialne (duchowe), takie jak np. zwyczaje, obrzędy, język, zachowane w ludzkiej pamięci nazwy, historie, opowieści stanowiące o tożsamości lokalnej i przekazywane z pokolenia na pokolenie. Specyficzną grupą elementów niematerialnych są wydarzenia i uroczystości rocznicowe, mające na celu utrwalanie pamięci zbiorowej o wydarzeniach historycznych (np. działalność historycznych grup rekonstrukcyjnych). Niestety, są mniej trwałe i mogą podlegać szybszej degradacji niż zasoby materialne.

Trwałość dawnych struktur i form przestrzennych należy do wartości i cech wyjątkowych, składających się na współcześnie definiowaną tożsamość kulturowo-historyczną przestrzeni geograficznej. Postępująca od XIX wieku industrializacja i nowa urbanizacja wywołały presję na historyczne przestrzenie. Następowała radykalna zmiana struktury miast, co doprowadziło do zacierania istniejących przestrzeni pamięci, ich modyfikowania lub ograniczania - przekształcone lub zlikwidowane obiekty, miejsca zastępowane tablicami, pomnikami, świadczącymi o ciągłości pamięci. Proces zachowania pamięci w topografii miasta nie zawsze jest możliwy, co w konsekwencji prowadziło do jej zatarcia. Przykładem zatarcia pamięci w topografii miasta jest Warszawa, która po II wojnie światowej, szczególne jej le- 
wobrzeżna część, otrzymała swego rodzaju nową tożsamość, a przestrzeń pamięci historycznej sprzed II wojny światowej uległa znacznej modyfikacji lub całkowitej likwidacji. W tym aspekcie można mówić również o przestrzeni wymarlej, opuszczonej lub diametralnie przekształconej.

\subsubsection{EDUKACJA I WYCHOWANIE}

Kontakt turysty lub krajoznawcy z przestrzenią śmierci rodzi wiele skutków wychowawczych i socjalizacyjnych. Turystyka ma wszechstronne możliwości oddziaływania na rozwój osobowości człowieka, a jej wychowawcze skutki dotyczą nie tylko samych turystów, ale również mieszkańców obszarów turystycznych. K. PRZECŁAWSKI (1996), opisując wychowawcze aspekty turystyki, zwraca uwagę na cele wychowania przez turystykę - pozytywne (eufunkcje) i negatywne (dysfunkcje) - oraz na czynniki determinujące wychowawcze efekty turystyki.

Głównym celem wychowawczym turystyki jest poznanie nieznanej zbiorowości, kultury i ich zrozumienie. Przez bezpośredni kontakt z przestrzenią śmierci turysta jest zmuszony do jej interpretacji. Jeżeli proces ten jest dodatkowo wspomagany przekazem wiedzy (np. za pośrednictwem opisu przewodnickiego), to percepcja śmierci może mieć zobiektywizowany charakter.

Do pozytywnych funkcji tanatoturystyki (eufunkcji) zaliczymy kształtowanie określonych postaw wobec śmierci, kształtowanie empatii do drugiego człowieka, kreacje działalności twórczej oraz poznanie problematyki eschatologicznej. Proces poznawczy kultury śmierci, ważny zwłaszcza dla młodych turystów, polega na bezpośrednim poznaniu i zrozumieniu semiotyki śmierci, jej symboliki, tradycji i obrzędowości.

Tanatoturystyka kształtuje określone postawy wobec różnych sfer rzeczywistości, w tym postawy altruistyczne wobec różnic kulturowych w postrzeganiu i ocenie śmierci. W oparciu o działalność krajoznawczą kształtuje świadomość narodową i postawę patriotyczną, utrwalając pamięć o „śmierci za ojczyznę". Wycieczki do miejsc zagłady czy na cmentarze wyznaniowe mogą prowadzić do lepszej integracji członków społeczności, składającej się z przedstawicieli różnych wyznań, kultur czy narodów. Tanatoturystyka dostarczając emocjonalnych przeżyć kształtuje uczucia, które są świadomą interpretacją emocji, uwrażliwia na sacrum śmierci, wyzwala empatię wobec cierpienia i bólu po śmierci drugiego człowieka. Działalność twórcza może objawiać się w postaci konkretnych prac na rzecz odwiedzanych miejsc. Może to być porządkowanie cmentarzy, grobów, mogił w trakcie wakacyjnych obozów, organizowanie szlaków tematycznych upamiętniających wydarzenia i ludzi, upowszechniających tragiczną historię. Działalność w zakresie 
porządkowania lub organizowania przestrzeni śmierci może być istotnym czynnikiem resocjalizacyjnym. Wycieczki tanatoturystyczne mogą kształtować i rozwijać zainteresowanie eschatologią, mogą być pomocne $\mathrm{w}$ zrozumieniu sensu życia i w przygotowaniu do „śmierci drugiego", tym samym wspierać pedagogikę śmierci.

Wychowawcze i edukacyjne funkcje tanatoturystyki nie ograniczają się tylko do kształtowania osobowości turysty. Tanatoturystyka oddziałuje wychowawczo również na ludność miejscową. Zetknięcie kultur, systemów wartości, wzorów zachowania powoduje u mieszkańców rozbudzenie zainteresowań i wzbogacenie wiedzy. Zmiany te zachodzą na gruncie poznawczym, kształtowania postaw i działania twórczego. Przykładem może być zmiana $\mathrm{w}$ ocenie cmentarzy wojennych $\mathrm{z}$ I wojny światowej $\mathrm{w}$ Beskidzie Niskim. Cmentarze te jeszcze w latach dziewięćdziesiątych XX wieku pozostawały zdewastowane i zapomniane, traktowane były przez lokalną społeczność jak obcy element miejscowego krajobrazu. Dziś cmentarze są odrestaurowywane, stanowią materialne dziedzictwo Bitwy Gorlickiej, której historia stała się podstawą zorganizowania produktu turystycznego, jakim jest Szlak Cmentarzy Wojskowych I Wojny Światowej. Proces zmian został zapoczątkowany przez zainteresowanych cmentarzami turystów i krajoznawców.
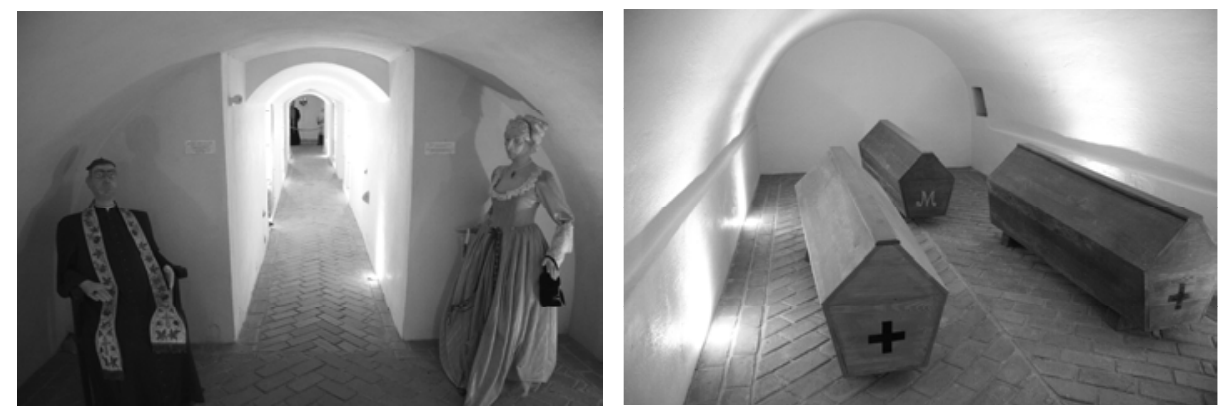

Fot. 11, 12. Krypty w Sanktuarium Matki Bożej Kodeńskiej - Polska (autor: S. Tanaś)

Niestety ruch turystyczny generuje również niepożądane, negatywne funkcje. Dysfunkcje tanatoturystyki wynikać mogą z powierzchownego poznania przestrzeni śmierci, traktowanej jako przestrzeń niechciana, naładowanej negatywnymi emocjami. Przestrzeń śmierci może być uważana za miejsce kontaktu z popkulturowym wizerunkiem śmierci. Ruch turystyczny może prowadzić do nadmiernego i niepożądanego eksploatowania tej przestrzeni, jej komercjalizacji turystycznej i profanacji. Z tego względu lokalna 
społeczność może negatywnie odnosić się do wykorzystania przestrzeni sacrum na potrzeby turystyki (fot. 10, 11).

O sile wychowawczego oddziaływania turystyki decydują: turysta (jego rola i pozycja społeczna, doświadczenie turystyczne), wartości odwiedzanego miejsca, organizacja wycieczki oraz osobowość wychowawcy (przewodnika, organizatora) (PRZECŁAWSKI 1996). Wymienione czynniki mogą wywoływać określone zachowania pożądane (socjalizacyjne) lub niepożądane (dewiacyjne). W przypadku przestrzeni śmierci obserwujemy niepożądane zachowania turystów, najczęściej nierespektujących powagi miejsca lub traktujących przestrzeń śmierci za niezwykłą atrakcję turystyczną.

Celem poznawczej wizyty $\mathrm{w}$ przestrzeni śmierci, z perspektywy problematyki pedagogicznej i edukacyjnej, jest m.in. uświadomienie i przekazanie wzorów postępowania, zachowania wobec śmierci, ochrona przestrzeni śmierci, obrzędowości, tradycji będących elementami dziedzictwa kulturowego utrwalającego tożsamość narodową, regionalną i lokalną. Efektem tego powinno być zrozumienie potrzeby organizowania infrastruktury turystycznej, szlaków, tablic, przewodników służących propagowaniu wiedzy historycznej oraz zrozumienie działań instytucji pracujących na rzecz ochrony i zachowania dziedzictwa kulturowego, w tym na rzecz ochrony, np. zabytkowej przestrzeni sepulkralnej. Jednym z celów interpretacji jest obalanie mitów, błędnych przekonań, które są powszechne w sferze percepcji śmierci. Edukacja tanatologiczna z zakresu historii śmierci, umiejętności "czytania” przestrzeni cmentarzy, odkodowywania symboliki sztuki sepulkralnej powinna $\mathrm{z}$ tego względu obejmować również przewodników turystycznych, których jakość przekazu determinuje stosunek odbiorcy (turysty) do śmierci, zmieniając jego postawę $\mathrm{i}$ zachowanie $\mathrm{w}$ obrębie przestrzeni śmierci. Działalność edukacyjna i wychowawcza $w$ ramach tanatoturystyki winna zmierzać do zaangażowania turysty lub krajoznawcy $\mathrm{w}$ interpretację dziedzictwa kulturowego w takim stopniu, aby zachęcić do ochrony i racjonalnego zarządzania walorami kultury śmierci.

\subsubsection{KRAJOZNAWSTWO W PRZESTRZENI TANATOTURYSTYKI}

Krajoznawstwo to opis szczegółowy kraju bądź jego regionu lub wszechstronna wiedza o kraju rodzinnym, w szczególności o swoim regionie (Międzynarodowy... 1961). Krajoznawstwo nie musi być tożsame z turystyką, ponieważ zdobywanie wiedzy o regionie nie musi odbywać się w czasie wolnym od pracy. Współcześnie krajoznawstwo pełni funkcję przede wszystkim edukacyjną i kulturalną, pobudzając zainteresowanie dziedzictwem kulturowym, propagując wartości, normy i wzorce kulturowe. Krajoznawstwo uczy 
umiejętności wyboru tego, co z dóbr kultury jest najcenniejsze i najbardziej wartościowe, co prowadzi do wszechstronnego rozwoju osobowości (KRUCZEK, KUREK, NOWACKI 2007, s. 21). W. LIPNIACKI (1985) wskazuje na działalność poznawczą w krajoznawstwie jako przyczynek do integracji wiedzy. Uogólniające spojrzenie krajoznawcze może wpływać na zmiany w dotychczasowym sposobie myślenia o poznawanym świecie, w tym również o śmierci.

Organizowanie zajęć dydaktycznych lub wychowawczych w określonych przestrzeniach tanatoturystyki wzmacnia przekaz historyczny, światopoglądowy i religijny doprowadzając do socjalizacji społecznej i kształcenia postaw patriotycznych.

Wycieczki do Państwowego Muzeum Auschwitz-Birkenau w Oświęcimiu mają m.in. na celu uświadomienie ogromu zbrodni popełnionej przez hitlerowców, ale również mają przestrzegać przed „powtórką z historii”. Obserwacja odwiedzających muzeum i jego otoczenie (wykazujących się m.in. brakiem refleksji i niedostatecznym zachowaniem powagi, czy nadmiernym filmowaniem i fotografowaniem), zagospodarowanie turystyczne otoczenia muzeum (płatne parkingi, baza gastronomiczna i noclegowa, sklepy z pamiątkami, obsługa i informacja turystyczna), turystyczny motyw odwiedzin muzeum (komercyjny produkt turystyczny) świadczą o traktowaniu byłego obozu zagłady jak produktu turystycznego. Ocena takiego wykorzystania przestrzeni śmierci jest bardzo trudna, ponieważ forma organizacji wycieczki może być uproszczoną próbą wsparcia świadomego przekazu wiedzy o historycznym miejscu lub sposobem na komercjalizację przestrzeni śmierci.

Poznanie krajoznawcze jest umiejscowione w czasie i w przestrzeni geograficznej. Krajoznawstwo obejmuje każdy wymiar czasowy - zarówno przeszłość, teraźniejszość, jak i przyszłość. Przeszłość należy rozpatrywać jako skarbiec wiedzy, nie jako grobowiec przeszłości. Uczy bowiem rozumieć historię i teraźniejszość, będącą jedynie etapem niezbyt odległej przyszłości. Wobec tego, poprzez zrozumienie przeszłości i działanie teraźniejsze, krajoznawca pomnaża zasoby kulturowe dla przyszłych pokolen. $Z$ tego względu poznanie i zrozumienie historii śmierci, znaczenia śmierci w kulturze regionu powinno być bodźcem do poszanowania i afirmacji życia oraz pracy na rzecz przyszłych pokoleń.

Krajoznawca interesuje się w szczególności ziemią ojczystą, wobec czego umacnia odrębność kulturową, narodową i regionalną, natomiast kraj rozumie jako środowisko wychowawcze, jednolite terytorialnie, społecznie i kulturowo, do którego przystosował się w trakcie swojego życia. To przystosowanie ma wpływ na emocjonalne związki ze swoją "małą ojczyzną", z lokalną społecznością, lokalnym dziedzictwem kulturowym. W przypadku 
śmierci będzie to np. tradycja obrzędowości żałobnej. Krajoznawca nie zadowoli się wiedzą przekazaną, lecz odkrywa ją na własny sposób, dążąc do szczegółowego poznania rzeczy i nieznanych faktów. Jego poznanie ma charakter interdyscyplinarny. Krajoznawca nie tylko poznaje otaczająca go rzeczywistość, ale również poprzez przetwarzanie pozyskanych informacji może kształtować ją od nowa. Poznawane środowisko wychowuje go, wzbogaca i uszlachetnia (LIPNIACKI 1985).

W przypadku działalności turystyczno-krajoznawczej ideałem wychowania jest ukształtowanie człowieka wrażliwego intelektualnie i społecznie, przygotowanego do świadomego życia w konkretnym środowisku geograficznym, przyrodniczym i społecznym, jak również rozwinięcie jego motywacji do ciągłego samowychowania i samokształcenia. W przypadku zainteresowania przestrzenią śmierci jako naczelny cel należy przyjąć nabycie wartości humanistycznych, takich jak szacunek do życia i śmierci, poszanowanie człowieka, jego godności i wolności. Godność i wolność człowieka jest ściśle skorelowana ze stosunkiem do historii państwa i narodu.

Cmentarze, pomniki, muzea winny być miejscem wykorzystywanym $\mathrm{w}$ procesie kształcenia postaw humanistycznych, w tym patriotycznych. W kanonie krajoznawczym powinny znaleźć się przestrzenie i artefakty upamiętniające "śmierć narodową", jak np. cmentarze (w tym nekropolie narodowe), grobowce, krypty i kaplice grobowe (groby władców i ich rodzin, groby pisarzy i artystów, przywódców i działaczy politycznych, groby duchownych, błogosławionych i świętych, groby symboliczne, kaplice i grobowce rodowe, krypty kościelne i ossuaria), miejsca masowej śmierci i zbiorowe mogiły (obozy koncentracyjne, obozy zagłady, obozy jenieckie, mogiły partyzanckie), muzea, wystawy i wydarzenia historyczne (kolekcje portretów trumiennych, krzyże, sarkofagi, płyty nagrobne i epitafia, starodruki z mowami pogrzebowymi, rytuały pogrzebowe, misteria, święta religijne) oraz inne obiekty upamiętniające narodową kulturę śmierci (fot. 13, 14).

Postawa patriotyczna przejawia się również w przeciwstawianiu się działaniom destrukcyjnym oraz traktowaniu przejawów życia społecznego i efektów działania narodu jako rezultatów własnej pracy. W tym przypadku przestrzenie tanatoturystyki są miejscem kształtowania postaw tolerancji i szacunku do innych przekonań, tradycji i religii, miejscem uznania prawa drugiego do odmiennych poglądów („Wszyscy jesteśmy równi wobec śmierci”). Gotowość niesienia opieki i pomocy jednostkom słabszym, potrzebującym dotyczy również "umierających" cmentarzy, osamotnionych po zakrętach historycznych, opuszczonych w konsekwencji przesiedleń. Stosunek do dziedzictwa kulturowego winien uwzględniać postawy niezbędne do racjonalnego i efektywnego korzystania z dóbr kultury będących własnością i skarbem narodu. 

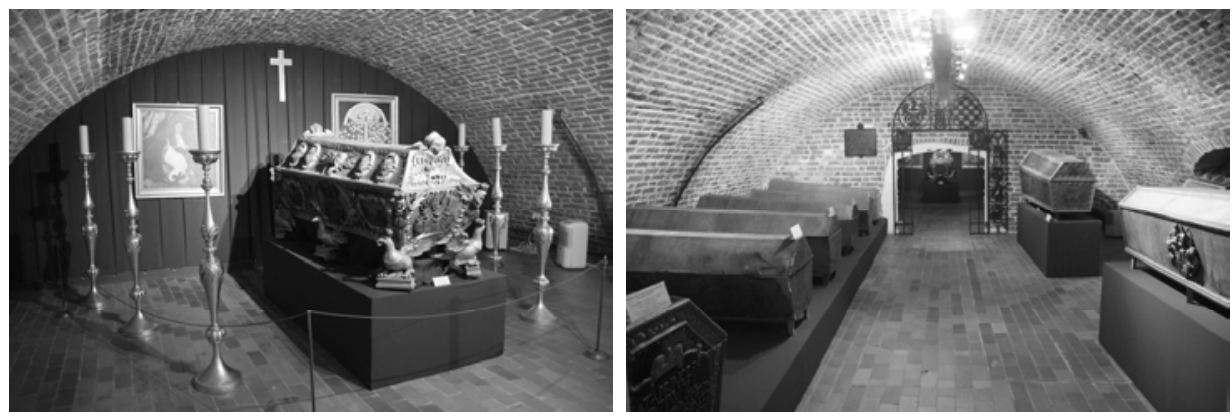

Fot. 13, 14. Wystawa „Memoriae Piastorum Principum Silesiae” w Muzeum Piastów Śląskich w Brzegu

(autor: S. Tanaś)

Poza wymienionymi celami działalności krajoznawczej ważny jest cel dokumentacyjny i popularyzacyjny. Cel dokumentacyjny realizowany jest poprzez kompletowanie kartotek, fotografii, filmów, rycin stanowiących podstawę zachowania $\mathrm{w}$ pamięci zastanej lub historycznej rzeczywistości, którą można by wykorzystać w przyszłości do jej odtworzenia. Temu służyć może kolekcjonowanie fotografii obiektów sepulkralnych. Cel popularyzacyjny realizowany jest przez przekazywanie społeczeństwu zdobytej wiedzy na temat przestrzeni śmierci i jej percepcji.

Reasumując rozważania zagadnień krajoznawczych w przestrzeni śmierci można powiedzieć, że przestrzeń tanatoturystyki sprzyja realizacji celów krajoznawczych, tym samym wspomaga proces edukacji i wychowania w poczuciu tożsamości lokalnej i narodowej oraz budowania, szczególnie wśród młodego pokolenia, postaw patriotycznych opartych na historii „małej ojczyzny" i historii całego narodu.

\subsection{ROZWÓJ PRZESTRZENI TANATOTURYSTYKI NA PRZYKŁADZIE PAMIĘCI O AKTACH TERRORYSTYCZNYCH I LUDOBÓJSTWIE}

W latach osiemdziesiątych minionego wieku zaczęto odnotowywać podróże poznawcze do miejsc, w których w stosunkowo nieodległej przeszłości miał miejsce akt terroru lub zbrodni wojennej. Choć podróże do miejsc terroru, ludobójstwa czy zdarzeń zbrojnych mają długą historię, to wycieczki w celu poznania miejsca zbrodni - o której pamięć, szczególnie wśród lokalnej społeczności jest nadal żywa wywołując silne emocje - były i są kontrowersyjną nowością (SHARPLEY, STONE, red. 2009, STONE 2012). Chęć odbycia tego typu 
podróży może wynikać z różnych motywów, np. z potrzeby oddania czci ofiarom, empatii wobec nich i ich bliskich czy upamiętnienia faktu zbrodni. Potrzeby turystów mogą mieć jednak charakter czysto emocjonalny, m.in. chęć dotarcia do miejsca napiętnowanego złem, okrucieństwem, noszącego etykietę miejsca niebezpiecznego lub zakazanego, budzącego strach i odrazę.

Konflikty zbrojne i terroryzm należą do grupy czynników mających wpływ na ograniczenie lub regresję ruchu turystycznego, pozostałe to m.in. czynniki społeczne (przestępczość, różnice kulturowe), polityczne (konflikty na tle politycznym lub religijnym), zdrowotne (epidemie, choroby zakaźne), przemysłowe (zagrożenia chemiczne i jądrowe) i środowiskowe (klęski żywiołowe). Głównym powodem takiego stanu rzeczy jest brak możliwości zagwarantowania bezpieczeństwa turystom i organizatorom podróży oraz utrudnienia logistyczne $\mathrm{w}$ zorganizowaniu pobytu turystycznego na obszarach niebezpiecznych.

Do czynników ograniczających rozwój turystyki należy również zaliczyć bariery natury etycznej. Czy turysta, realizując cele poznawczo-turystyczne, powinien odwiedzać miejsca, w których cierpią i giną ludzie, jednocześnie obserwując skutki przemocy, niekoniecznie łącząc pobyt z celami wyższymi, chociażby takimi, jak pomoc humanitarna? Najczęściej, ze względów bezpieczeństwa lub politycznych turyści są w takich sytuacjach izolowani od świata zewnętrznego, są kwaterowani w zamkniętych, bezpiecznych ośrodkach, które można określić "gattami turystycznymi”, podróżują w konwojach chronionych przez uzbrojone jednostki policyjne, wojskowe lub prywatne, obserwując rzeczywistość z „bezpiecznej” odległości, choć w bezpośrednim kontakcie. W takiej sytuacji możemy mówić wręcz o teatralizacji cierpienia ludzkiego.

We współczesnym świecie turystyka jest uważana za jeden z najbardziej dochodowych sektorów gospodarki. W roku 2012 turystyka wygenerowała 9\% światowego PKB oraz 8\% eksportu najsłabiej rozwiniętych państw (LDC), przynosząc rocznie 1,2 biliona dolarów wpływów z eksportu, przy 1,035 miliarda przyjazdów turystów zagranicznych. Jedno na 12 miejsc pracy na świecie jest zorganizowane w sektorze turystyki. W roku 2012 wzrost przyjazdów turystów zagranicznych w stosunku do ubiegłego roku był silniejszy w gospodarkach rozwijających się $(+4,1 \%)$. W Afryce wzrost osiągnął 6\%, po dużym, 9-procentowym spadku w 2011 roku, głównie ze względu na niepokoje w Afryce Północnej. W roku 2011 obserwowano wyraźny spadek przyjazdów do Tunezji (-31\%) i Egiptu (-32\%) w stosunku do 2010 roku, będący konsekwencją niepokojów politycznych i aktów przemocy. Podobny trend obserwowano w 2011 roku w Jordanii (-13\%), Libanie (-24\%), Palestynie (-15\%) i Syrii (-41\%) (UNWTO 2012, 2013). 
Sektor turystyki jest jednym z głównych działów wielu gospodarek świata, w szczególności krajów o nieustabilizowanej sytuacji społeczno-politycznej i słabo rozwiniętych gospodarczo, ale atrakcyjnych z perspektywy realizowania potrzeb turystycznych. Przytoczone wyniki przyjazdów zagranicznych w 2011 i 2012 roku tylko w Afryce Północnej pokazują, w jakim stopniu turystyka jest wrażliwa na niepokoje polityczne i brak bezpieczeństwa, będące konsekwencją działalności terrorystycznej, zbrojnej lub kryminalnej.

Akty przemocy, wojna i terroryzm z pewnością ograniczają ruch turystyczny w relatywnie krótkich okresach. Na zmiany w ruchu turystycznym w regionie Azji Południowo-Wschodniej, jakie były konsekwencją ataku terrorystycznego na Światowe Centrum Handlu (WTC) w Nowym Jorku w roku 2001, wskazują C. EDMOND i J. MAK (2006). Jednoznacznie wykazują, że ruch turystyczny w krótkiej perspektywie czasu spada, lecz z czasem powraca do wcześniej wyznaczonego trendu. Niestety wiążą się z tym znaczne straty finansowe w wielu sektorach gospodarki (rys. 28).

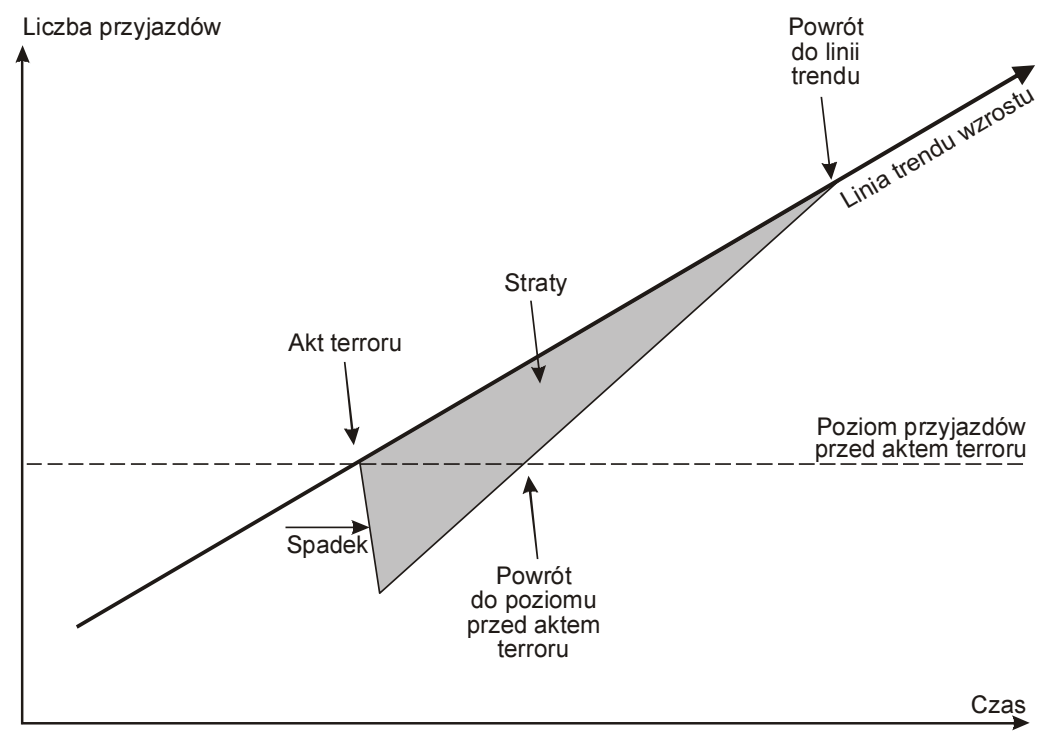

Rys. 28. Schemat spadku i wzrostu ruchu turystycznego po akcie terroru Źródło: opracowanie własne na podstawie C. EDMOND, J. MAK (2006, s. 12)

W dłuższej perspektywie akty przemocy (ludobójstwa, terroru) mogą zostać upamiętnione $\mathrm{w}$ przestrzeni geograficznej poprzez symbole - pomniki, mogily, muzea czy parki tematyczne (historyczne). Z perspektywy czasu zdarzenia tego typu mogą stać się impulsem do rozwoju historycznego wa- 
loru związanego z aktem przemocy, następnie ewoluując do atrakcji turystycznej i produktu turystycznego. Możemy mówić wówczas o powstaniu przestrzeni pamięci lub przestrzeni symbolicznej, wielokrotnie odwiedzanej poznawczo przez turystów.

\subsubsection{TERROR I LUDOBÓJSTWO JAKO BARIERA RUCHU TURYSTYCZNEGO}

W drugiej połowie XX i na początku XXI wieku w dobie intensywnego rozwoju gospodarczego świata, $w$ tym turystyki, mamy wciąż do czynienia z konfliktami zbrojnymi, niejednokrotnie skutkiem których są akty zbrodni wojennych i ludobójstwa. Niepokoje wojenne skutecznie odstraszają potencjalnych turystów, choć zdarzają się wyjazdy na obszary konfliktów w celu bezpośredniego kontaktu "turysty” z rzeczywistością wojenną (współcześnie jest to m.in. pogranicze Korei Północnej i Południowej, Syria, Afganistan, Pakistan, Irak).

Istotna dla opisywanego problemu jest skala współczesnych zbrodni wobec ludzkości, które, zgodnie z postawioną tezą, stanowią czynnik znacznie lub całkowicie ograniczający ruch turystyczny. Niestety stosunkowo nieodległe czasowo zbrodnie ludobójstwa miały i mają miejsce na obszarach o znaczących walorach turystycznych (BEECH 2009)8. Akty ludobójstwa w ostatnim półwieczu miały miejsce m.in. w Bangaldeszu, Kambodży (zbrodnie ludobójstwa popełnione przez Czerwonych Khmerów), północnym Iraku (masakra Kurdów), byłej Jugosławii (masakra w Srebrenicy), Rwandzie (konflikt między Tutsi i Hutu), Darfurze (konflikt w Sudanie), Syrii (wojna domowa) i na wielu innych obszarach Afryki i Azji (BRUNETEAU 2005).

Terroryzm jest formą przemocy politycznej polegającej na stosowaniu morderstwa lub zniszczenia (albo na groźbie zastosowania takich środków) w celu wywołania szoku i ekstremalnego zastraszenia jednostek, grup, społeczeństw lub rządów, czego efektem mają być wymuszenia pożądanych ustępstw politycznych, sprowokowanie nieprzemyślanych działań i zademonstrowanie własnych politycznych przekonań (BOLECHÓW 2002, s. 35). W grupie ludności cywilnej atakowanej poprzez akty terrorystyczne znaleźli się w latach sześćdziesiątych $\mathrm{XX}$ wieku również turyści, którzy stali się celem bojówek terrorystycznych, partyzantów i kryminalistów, porywających lub uśmiercających dla rozgłosu czy osiągnięcia własnych celów politycznych lub korzyści majątkowych. W przypadku ataków na turystów możemy

${ }^{8}$ Turystyka do miejsc dokumentujących ludobójstwo w anglojęzycznej literaturze przedmiotu nosi nazwę genocide tourism (turystyka ludobójstwa) (BEECH 2009). 
mówić o terroryzmie międzynarodowym, angażującym obywateli lub terytorium więcej niż jednego kraju. Terroryzm religijny może z kolei godzić w turystykę pielgrzymkową.

Tab. 11. Wybrane ataki terrorystyczne na turystów na świecie

\begin{tabular}{|c|c|c|}
\hline Data & Miejsce ataku & Opis zdarzenia \\
\hline 5 III 1970 & Tel Awiw (Izrael) & Atak na Hotel Savoy w Tel Awiwie \\
\hline 13 II 1978 & Sydney (Australia) & Zamach na hotel Hilton w Sydney \\
\hline 2 XI 1979 & $\begin{array}{l}\text { Mekka (Arabia Sau- } \\
\text { dyjska) }\end{array}$ & $\begin{array}{l}\text { Zajęcie Wielkiego Meczetu w Mekce przez } \\
\text { islamskich terrorystów }\end{array}$ \\
\hline 26 IX 1980 & Monachium (Niemcy) & Zamach bombowy podczas Oktoberfest \\
\hline $7 \times 1985$ & Aleksandria (Egipt) & Porwanie statku Achille Lauro \\
\hline 22 IX 1989 & Deal (Irlandia) & $\begin{array}{l}\text { Wybuch bomby podłożonej przez IRA w } \\
\text { ośrodku wczasowym Royal Marines w Deal }\end{array}$ \\
\hline 18 IV 1996 & Giza (Egipt) & $\begin{array}{l}\text { Zastrzelenie w pobliżu piramid w Gizie grec- } \\
\text { kich turystów, których islamiści wzięli za } \\
\text { Izraelczyków }\end{array}$ \\
\hline 28 VII 1996 & Atlanta (USA) & $\begin{array}{l}\text { Wybuch bomby w czasie koncertu Atlanta } \\
\text { Olympic Games }\end{array}$ \\
\hline 18 IX 1997 & Kair (Egipt) & $\begin{array}{l}\text { Zamach przed Muzeum Egipskim, w wyniku } \\
\text { którego zginęli niemieccy turyści }\end{array}$ \\
\hline 17 XI 1997 & Luksor (Egipt) & Atak na turystów \\
\hline $15 \times 1997$ & Kolombo (Sri Lanka) & Atak na Hotel Galedari Meridian \\
\hline 11 IX 2001 & Nowy York (USA) & Atak na Światowe Centrum Handlu (WTC) \\
\hline $23-26 \times 2002$ & Moskwa (Rosja) & $\begin{array}{l}\text { Atak czeczeńskich terrorystów na Centrum } \\
\text { Teatralne na Dubrowce w Moskwie }\end{array}$ \\
\hline $28 \times 2002$ & Mombasa (Kenia) & $\begin{array}{l}\text { Zamach na hotel i turystów izraelskich oraz } \\
\text { próba zestrzelenia samolotu w Mombasie }\end{array}$ \\
\hline $12 \times 2002$ & Kuta (Bali - Indonezja) & Dwa zamachy bombowe na bar i klub \\
\hline $16 \mathrm{~V} 2003$ & Casablanca (Maroko) & Atak samobójczy \\
\hline 5 VIII 2003 & Dżakarta (Indonezja) & Atak bombowy na Hotel Marriott \\
\hline 11 III 2004 & Madryt (Hiszpania) & $\begin{array}{l}\text { Zamachy bombowe w pociągach } \\
\text { podmiejskich w Madrycie }\end{array}$ \\
\hline $7 \times 2004$ & Taba (Egipt) & Zamach bombowy \\
\hline 23 VII 2005 & Sharm El Shejk (Egipt) & Zamachy bombowe \\
\hline 11 VII 2006 & $\begin{array}{l}\text { Srinagar, Jammu, } \\
\text { Kashmir (Indie) }\end{array}$ & Zamachy bombowe na turystów \\
\hline 24 IV 2006 & Dahab (Egipt) & Zamachy bombowe \\
\hline 31 XII 2006 & Bangkok (Tajlandia) & Zamachy bombowe \\
\hline 20 IX 2008 & Islamabad (Pakistan) & Zamach na hotel Marriott \\
\hline $26-29$ XI 2008 & Bombaj (Indie) & Ataki na hotele w centrum Bombaju \\
\hline 17 VII 2009 & Dżakarta (Indonezja) & $\begin{array}{l}\text { Wybuchy bomb w luksusowych hotelach } \\
\text { Marriott i Ritz-Carlton }\end{array}$ \\
\hline 18 VII 2012 & Burgas (Bułgaria) & $\begin{array}{l}\text { Zamach samobójczy na autokar z turystami z } \\
\text { Izraela autobus eksplodował przed lotniskiem }\end{array}$ \\
\hline
\end{tabular}

Źródło: opracowanie własne. 
Turystyka przyjazdowa i wyjazdowa jest bardzo podatna na niestabilność polityczną, np. wojny, akty przemocy, zamieszki, przewroty czy strajki. Przykłady najkrwawszych i najbardziej spektakularnych ataków terrorystycznych wobec turystów wskazują, że niestabilność polityczna jest jednym $\mathrm{z}$ elementów, który niszczy turystykę $\mathrm{w}$ dowolnym miejscu świata. Terroryści za cel swych ataków wybierają hotele, restauracje, bary, kluby, dworce, w taki sposób, żeby wśród ofiar byli turyści wielu narodowości (tab. 11).

W XX wieku terroryzm stał się akceptowaną taktyką powstańczą, szczególnie w krajach rozwijających się na obszarach kolonialnych Afryki i Azji Południowej, gdzie celem ataków stały się osoby przyjezdne. W krajach wysoko rozwiniętych terroryzm rozwinął się m.in. za sprawą baskijskiej organizacji terrorystycznej ETA (Kraj Basków i Wolność) oraz Irlandzkiej Armii Republikańskiej (IRA), które również atakowały cele turystyczne (np. ETA w 1996 roku rozpoczęła zmasowane ataki na kurorty turystyczne Hiszpanii, w tym na Majorce, a IRA podkładała bomby w centrach rozrywki i restauracjach na obszarze Wielkiej Brytanii). Od lat siedemdziesiątych minionego stulecia Front Wyzwolenia Narodowego Korsyki (FLNC) atakuje kompleksy turystyczne na Korsyce.

W latach sześćdziesiątych i siedemdziesiątych $X X$ wieku organizacje palestyńskie zainteresowały się transportem lotniczym, wydarzeniami sportowymi i centrami ruchu turystycznego jako łatwymi celami ataków o znaczeniu międzynarodowym $\mathrm{w}$ wojnie $\mathrm{z}$ Izraelem. Ataki na izraelskie cele turystyczne mają miejsce do dziś (najczęściej w Jerozolimie, Tel Awiwie, Hajfie).

$\mathrm{W}$ latach siedemdziesiątych kolejna fala terroru związana była z rozwojem fundamentalizmu islamskiego, którego głównym ośrodkiem stał się pod koniec dekady Iran. Podobne działania podjęły ugrupowania partyzanckie w Ameryce Łacińskiej i Azji Południowej, atakując cele turystyczne lub uprowadzając turystów dla rozgłosu lub pozyskania środków finansowych na walkę zbrojną. Niejednokrotnie porwań turystów dokonywały kartele narkotykowe $\mathrm{w}$ wojnie z miejscową władzą.

Od 1975 roku Ormiańska Tajna Armia na rzecz Wyzwolenia Armenii (ASALA) atakowała przez 10 lat biura linii lotniczych. W latach dziewięćdziesiątych miały miejsce ataki w Turcji (wcześniej również na Cyprze), były to uprowadzenia turystów lub zamachy na hotele i restauracje $\mathrm{w}$ miejscowościach wypoczynkowych, przeprowadzane m.in. przez członków Partii Pracujących Kurdystanu. W Egipcie w latach dziewięćdziesiątych minionego wieku jednym z głównych celów islamistycznego terroru byli również turyści. Pomijając tradycyjną niechęć fundamentalistów do szerzenia „zachodniej kultury" na islamskiej ziemi, gospodarka turystyczna jest jednak jednym z najważniejszych źródeł dochodów budżetowych Egiptu. W październiku 
1992 roku bojownicy islamscy zorganizowali zasadzkę na autobus turystyczny, zabijając jedną i raniąc kilka osób. Zabita kobieta była pierwszym cudzoziemcem zamordowanym $\mathrm{w}$ Egipcie $\mathrm{w}$ latach dziewięćdziesiątych, co tym samym rozpoczęło serię ataków na zagranicznych turystów, mających dać rozgłos medialny egipskim bojownikom walczącym z ówczesnym reżimem Hosniego Mubaraka.

W marcu 1993 roku walczący islamiści nakazali wszystkim cudzoziemcom wyjazd z kraju. Rozpoczęto liczne ataki na turystów, realizując plan załamania gospodarczego kraju i obalenia rządu. Akty przemocy miały miejsce podczas rejsów po Nilu, w Kairze (m.in. w kwietniu fundamentaliści islamscy ostrzelali omyłkowo przed hotelem turystów greckich, myląc ich z grupą izraelską; zginęło 18 osób), w Hurgadzie w prowincji Asjot w Górnym Egipcie. W latach 1992-1997 zginęło w Egipcie ponad 90 obcokrajowców. W rok po rozpoczęciu kampanii terroru, w 1993 roku, wpływy z turystyki spadły o połowę, tj. o 1,5 mld dolarów (Encyklopedia ... 2002, s. 403). Do najkrwawszych zamachów w Egipcie doszło w Luksorze (17 listopada 1997 r., przed kompleksem świątyń Deir el-Bahari miał miejsce atak członków Grupy Islamskiej na turystów; zginęły 62 osoby), Tabie (w październiku 2004 r. 34 ofiary śmiertelne ataków bombowych) i w Sharm el-Sheikh (23 lipca 2005 r. w wyniku wybuchów bomb zginęło 88 osób, a ponad 200 zostało rannych).

Ataki na turystów miały miejsce również $\mathrm{w}$ innych regionach świata. 16 maja 2003 roku w Casablance w Maroku w wyniku serii samobójczych zamachów bombowych terrorystów z grupy Jihadia Salafia, zginęło 33 cywilów, w tym zagraniczni turyści. 18 stycznia 2012 roku uzbrojeni napastnicy na północy Etiopii zaatakowali grupę europejskich turystów, zabijając pięciu, raniąc dwóch i porywając kolejnych dwóch. W archiwach prasowych można odnaleźć wiele informacji na temat ataków wobec turystów lub ich porwan, np. na Bali (w 2002 r. zamachy bombowe), w Islamabadzie, Bombaju i w wielu innych zakątkach świata, gdzie europejscy turyści zostali zaatakowani przez fundamentalistów islamskich mających na celu zastraszenie i zniechęcenie do przyjazdów. Przykładem wyłączenia obszaru dla turystyki w ostatnich latach jest jedna z najważniejszych atrakcji turystycznych w Pakistanie Dolina Swat, która okazała się być również jednym z najważniejszych celów Al Kaidy. Tym samym znany obszar trekkingu wysokogórskiego w północnym Pakistanie oraz brama do najwyższych partii Himalajów zostały zamknięte dla ruchu turystycznego. Najtragiczniejszy w historii atak terrorystyczny na himalaistów miał miejsce w czerwcu 2013 roku w bazie pod Nanga Parbat, w konsekwencji którego zginęło 10 obcokrajowców.

Najczęstszą metodą działania terrorystów są zamachy bombowe, ale w latach siedemdziesiątych XX wieku popularną metodą stały się upro- 
wadzenia zakładników oraz porwania samolotów i statków, dające dostęp do środków masowego przekazu (tab. 12).

W latach 1969-1981 doszło na świecie do ponad 550 porwań samolotów (Encyklopedia ... 2002, s. 225-226), w tym wielokrotnie z turystami na pokładzie. Spadek liczby porwań nastąpił w drugiej połowie lat osiemdziesiątych, przede wszystkim ze względu na rozwój środków bezpieczeństwa w lot-

Tab. 12. Wybrane ataki terrorystyczne na samoloty pasażerskie i terminale lotnisk na świecie, w których ucierpieli turyści

\begin{tabular}{|c|c|c|}
\hline Data & $\begin{array}{c}\text { Nazwa linii } \\
\text { lotniczych/ lotnisko }\end{array}$ & Opis (grupa terrorystyczna) \\
\hline 28 VII 1968 & EL AL & $\begin{array}{l}\text { Porwanie pierwszego samolotu izraelskiego (Ludowy } \\
\text { Front Wyzwolenia Palestyny - LFWP) }\end{array}$ \\
\hline $12 \times 1967$ & Cyprus Airways & $\begin{array}{l}\text { Katastrofa samolotu de Havilland DH } 106 \text { Comet, lot } \\
284, \text { w wyniku wybuchu bomby }\end{array}$ \\
\hline 21 II 1970 & Swissair & $\begin{array}{l}\text { Katastrofa samolotu Convair 990, lot 330, w wyniku } \\
\text { wybuchu bomby w luku bagażowym (LFWP) }\end{array}$ \\
\hline 6-9 IX 1970 & $\begin{array}{l}\text { ElAl, Swissair, BOAC, } \\
\text { TWA, Pan Am }\end{array}$ & $\begin{array}{l}\text { Porwanie pięciu samolotów i wysadzenie trzech z nich } \\
\text { na lotnisku Dawsons Field w Jordani (LFWP) }\end{array}$ \\
\hline 26 I 1972 & $\begin{array}{l}\text { Jugoslovenski } \\
\text { Aerotransport } \\
\end{array}$ & $\begin{array}{l}\text { Katastrofa samolotu McDonnel Douglas DC-9 w wy- } \\
\text { niku wybuchu bomby w luku bagażowym (Utaszy) }\end{array}$ \\
\hline $30 \mathrm{~V} 1972$ & Lod (Izrael) & Masakra na lotnisku Lod (Japońska Armia Czerwona) \\
\hline 27 VI 1976 & Air France & Uprowadzenie samolotu Airbus A-300, lot 139 (LFWP) \\
\hline 7 IX 1974 & TWA & $\begin{array}{l}\text { Katastrofa samolotu w wyniku wybuchu bomby } \\
\text { (LFWP) }\end{array}$ \\
\hline $13 \times 1977$ & Lufthansa & Uprowadzenie samolotu Boeing 737 (LFWP) \\
\hline 12 II 1979 & Air Rhodesia & Zestrzelony samolot Vickers Viscount, lot 825 (ZIPRA) \\
\hline 7 VIII 1982 & Ankara (Turcja) & Podłożenie bomby na lotnisku w Ankarze (ASALA) \\
\hline 23 VI 1985 & Air India & $\begin{array}{l}\text { Katastrofa samolotu Boeinga 747, lot 182, w wyniku } \\
\text { wybuchu bomby (Babbar Khalsa) }\end{array}$ \\
\hline 23 XI 1985 & Egypt Air & Uprowadzenie samolotu (Grupa Abu Nidala) \\
\hline 27 XII 1985 & $\begin{array}{l}\text { Wiedeń (Austria), } \\
\text { Rzym (Włochy) }\end{array}$ & Zamachy na lotniskach (Grupa Abu Nidala) \\
\hline 25 XII 1986 & Iraqi Airways & Uprowadzenie i katastrofa samolotu \\
\hline 29 XI 1986 & Korean Air & $\begin{array}{l}\text { Katastrofa samolotu Boeing 747, lot 858, w wyniku } \\
\text { wybuchu bomby (agenci Pn. Korei) }\end{array}$ \\
\hline 21 XII 1988 & $\begin{array}{l}\text { Pan American World } \\
\text { Airways (Lockerbie) }\end{array}$ & $\begin{array}{l}\text { Katastrofa samolotu Boeing 747, lot 103, w wyniku } \\
\text { wybuchu bomby (agenci libijscy) }\end{array}$ \\
\hline 19 IX 1989 & UTA & $\begin{array}{l}\text { Katastrofa samolotu McDonnell Douglas DC-10, lot } \\
772, \text { w wyniku wybuchu bomby (Libia) }\end{array}$ \\
\hline 24 XII 1994 & Air France & Uprowadzenie samolotu (Zbrojna Grupa Islamska) \\
\hline 23 XI 1996 & Ethiopian Airlines & $\begin{array}{l}\text { Uprowadzenie i katastrofa samolotu Boeing 767, lot } \\
961 \text { (etiopscy terroryści) }\end{array}$ \\
\hline 11 IX 2001 & $\begin{array}{l}\text { United Airlines, } \\
\text { American Airlines }\end{array}$ & $\begin{array}{l}\text { Uprowadzenie czterech samolotów amerykańskich } \\
\text { linii lotniczych i ich katastrofy (Al Kaida) }\end{array}$ \\
\hline
\end{tabular}

Źródło: opracowanie własne. 
nictwie. W latach 1969-1994 porwano 850 samolotów, w efekcie czego ofiarą padło 50 tys. ludzi, w tym 600 straciło życie (STRZEMIENIECKI 1994, s. 51). Większość ataków na turystów miała lub ma miejsce w najbiedniejszych krajach świata, gdzie turystyka odgrywa kluczową rolę w lokalnej gospodarce. Terroryści, chcąc zniechęcić turystów do przyjazdu, tym samym blokują rozwój gospodarczy i społeczny danego regionu. Turystyka międzynarodowa jest sektorem, który opiera się na kontaktach międzyludzkich i dialogu międzykulturowym. Sukces w turystyce potrzebuje stabilności politycznej, pokoju i bezpieczeństwa, z tego względu międzynarodowy terroryzm rodzi negatywne skutki gospodarcze, polityczne i społeczne, w szczególności w turystyce międzynarodowej (BACZWAROW, NAPIERAŁA 2002). Potwierdzają to przykłady największych zamachów terrorystycznych, godzących bezpośrednio lub pośrednio w gospodarkę turystyczną. Przełom wieków XX i XXI zapisał najbardziej krwawe akty terroru, takie jak ataki terrorystyczne w Egipcie w latach dziewięćdziesiątych i 2004-2005, największy $\mathrm{w}$ historii zamach terrorystyczny $\mathrm{z}$ wykorzystaniem samolotów pasażerskich we wrześniu 2001 roku w Stanach Zjednoczonych Ameryki czy najtragiczniejsze zamachy współczesnej Europy - w Madrycie w 2004 i w Londynie w 2005 roku.

Wyniki badań przeprowadzonych w Jordanii na grupie zagranicznych turystów z sześciu kontynentów (ALSARAYREH, JAWABREH, HELALAT 2010, s. 157) wskazują na polityczną niestabilność jako istotny czynnik oddziałujący na turystykę. Wojny między krajami są destrukcyjne nie tylko dla gospodarki turystycznej walczących państw, ale również dla krajów sąsiednich. Potwierdzeniem mogą być wojny w Zatoce Perskiej w latach 1991 i 2003. Ruch turystyczny w Iraku został prawie całkowicie ograniczony, również w krajach sąsiednich - Jordania i Syria. Podobnie niestabilna sytuacja w Palestynie, Syrii i Iranie ogranicza ruch turystyczny do Izraela. Oprócz bezpośrednich zagrożeń dla turystów oraz niszczenia infrastruktury turystycznej i historycznych atrakcji konflikty i akty terroru mają również długofalowy wpływ na wizerunek kraju lub regionu. Turystyka jest zawsze jedna z pierwszych ofiar zbrojnych konfliktów i aktów przemocy oraz jednym z głównych sektorów gospodarki, na jaki mają wpływ wojny, działania terrory-styczne lub niestabilność polityczna. Powołując się na cytowane wyniki badań stwierdzono, że aż 78\% respondentów pytało o sytuację polityczną w kraju przed wizytą, a 61\% respondentów posłuchało politycznych ostrze-żeń, aby nie wybierać się do określonego kraju w trakcie kryzysu.

Wymierne korzyści zamachów na turystów to:

a) gwarancja rozgłosu; 
b) zaszkodzenie rozwojowi branży turystycznej i jednocześnie całej gospodarce, powodując napięcia społeczne i osłabiając tym samym władze danego kraju;

c) brak ryzyka utraty poparcia ludności miejscowej ze względu na nieakceptowane i budzące głęboki sprzeciw zachowania turystów wynikające z różnic kulturowych oraz wskazanie na nierówności pomiędzy krajami rozwiniętymi i rozwijającymi się, czego symbolem jest luksusowa baza hotelowa;

d) fakt, że sektor turystyczny jest relatywnie łatwym celem ataków.

Biorąc po uwagę celowość ataków terrorystycznych wobec turystów można wyróżnić kategorie ataków ze względu na:

a) miejsce - atak $w$ docelowym miejscu wypoczynku lub w strefie tranzytowej między miejscem zamieszkania a miejscem wypoczynku (np. na lotniskach lub w środkach transportu);

b) cel - $\mathrm{w}$ trakcie ataku turysta jest bezpośrednim celem albo przypadkową ofiarą;

c) rozgłos - informacja o ataku wstrzymuje lub ogranicza ruch turystyczny do miejsca, w którym do niego doszło.

Turysta jest wielokrotnie przypadkową ofiarą ataku. Może zdarzyć się jednak, że terroryści według przemyślanego planu atakują wcześniej ustaloną grupę turystów lub turystów indywidualnych w celu uzyskania konkretnych korzyści, nierzadko korzyści majątkowych (porwanie i zagrożenie straceniem zakładników dla okupu). Najczęściej są to kraje, w których mają miejsce konflikty na tle gospodarczym, etnicznym, politycznym czy religijnym. Przykłady płyną z Turcji, Izraela, Palestyny, krajów Bliskiego Wschodu i Afryki, Peru, Meksyku i pozostałych krajów Ameryki Łacińskiej, Sri Lanki, Filipin i innych krajów Azji.

Nawet przy zachowaniu odpowiednich środków bezpieczeństwa w sektorze podróży i turystyki, zagrożenia terrorystycznego nie można całkowicie wyeliminować. Działalność odpowiednio przygotowanych służb może $\mathrm{z}$ pewnością pomóc $\mathrm{w}$ złagodzeniu społecznych i gospodarczych konsekwencji ataków terrorystycznych. Jednocześnie ważne jest, aby umacniać i upowszechniać pozytywne efekty turystyki przynoszącej korzyści finansowe zarówno ludności miejscowej, jak i systemowi społeczno-gospodarczemu państwa, potrzebującemu pomocy $\mathrm{w}$ stabilizacji polityczno-ekonomicznej. Podróże i turystyka przyczynia się do osłabienia czynników prowadzących do terroryzmu, poprzez wspieranie rozwoju społeczno-gospodarczego, tworzenie możliwości zatrudnienia oraz wspieranie wzajemnego zrozumienia i tolerancji. 


\subsubsection{PAMIĘĆ O LUDOBÓJSTWIE I TERRORZE JAKO STYMULATOR RUCHU TURYSTYCZNEGO}

B. BOLECHÓW (2002, s. 17) zwraca uwagę na subiektywne rozumienie niewinności i winy ofiar terroru. Winnymi mogą być turyści, ponieważ wspierają finansowo reżim, podobnie jak winą może być przynależność etniczna albo klasowa ofiar. Niektóre formy terroryzmu związane są z uderzeniem w ludzi niezaangażowanych bezpośrednio w konflikt, ale zaangażowaniem może być chociażby wspieranie gospodarki poprzez przyjazd turystyczny. Ten kto dla jednego jest terrorystą, dla innego jest bojownikiem o wolność. $\mathrm{Z}$ tej perspektywy obiekty dokumentujące terror mogą być pomnikami zbrodni i jednocześnie chwały. Rozumienie terroryzmu jest bardzo trudne, choć $\mathrm{z}$ perspektywy Zachodu jednoznacznie terroryzm jest zbrodnią.

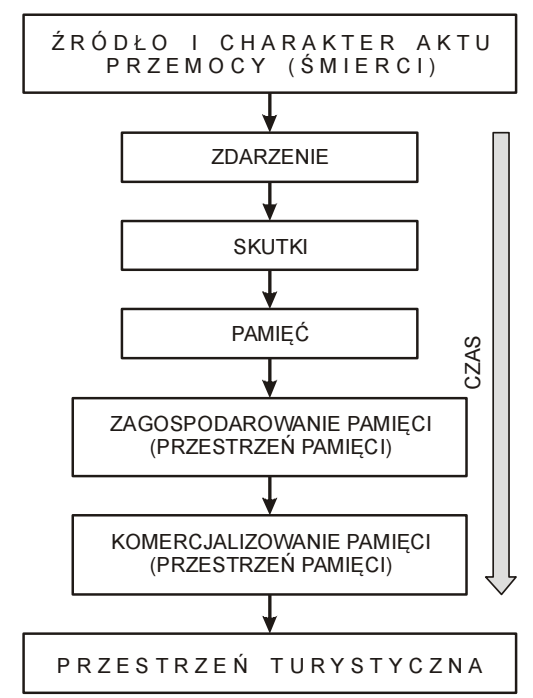

Rys. 29. Turystyczne wykorzystanie aktu przemocy w perspektywie czasu Źródło: opracowanie własne

Konsekwencją terroryzmu są miejsca pamięci odnotowujące zbrodnie, $\mathrm{z}$ czasem organizowane $\mathrm{w}$ muzea, mauzolea, miejsca pamięci odwiedzane w różnych celach przez rodziny ofiar, miejscową ludność lub turystów. Podróże do miejsc historycznie związanych z konfliktami zbrojnymi stały się popularne już $\mathrm{w}$ wieku XIX. Jednak dopiero $\mathrm{w}$ drugiej połowie XX wieku zarówno organizatorzy przestrzeni turystycznej, jak i sami turyści zaczęli traktować cmentarze, pomniki i miejsca dokumentujące akty przemocy w kategoriach atrakcji turystycznych. Dla upamiętnienia terroru lub innej zbrodni 
organizowana jest przestrzeń pamięci, która może podlegać komercjalizacji, tym samym przekształcając się $\mathrm{w}$ przestrzeń turystyczną i produkt turystyczny (rys. 29).

W ciągu ostatnich kilkudziesięciu lat odnotowano niezwykłą modę na nowy rodzaj muzeów, jakimi są muzea-pomniki. Celem ich tworzenia jest uczczenie, upamiętnienie, udokumentowanie i badanie historii przemocy (WILLIAMS 2007). W Europie powstało wiele muzeów i miejsc pamięci ludobójstwa XX wieku. W Polsce do grupy najbardziej znanych i najczęściej odwiedzanych należą muzea upamiętniające ofiary zbrodni wojennych $\mathrm{z}$ lat 1939-1945, m.in. Państwowe Muzeum Auschwitz-Birkenau w Oświęcimiu, były obóz jeniecki (więzienie) na górze Święty Krzyż w Górach Świętokrzyskich czy nowo organizowane Mauzoleum Martyrologii Wsi Polskich w Michniowie. W latach dziewięćdziesiątych po zmianach ustrojowych pojawiły się izby pamięci zbrodni stalinowskich (np. Oddział Muzeum Historycznego Miasta Krakowa ze stałą wystawą „Krakowianie wobec terroru 1939-1945-1956") i muzea walki zbrojnej Polski Podziemnej (m.in. nowoczesne i interaktywne Muzeum Powstania Warszawskiego), choć nadal nie zostało zorganizowane w Polsce centralne muzeum zbrodni stalinowskich.
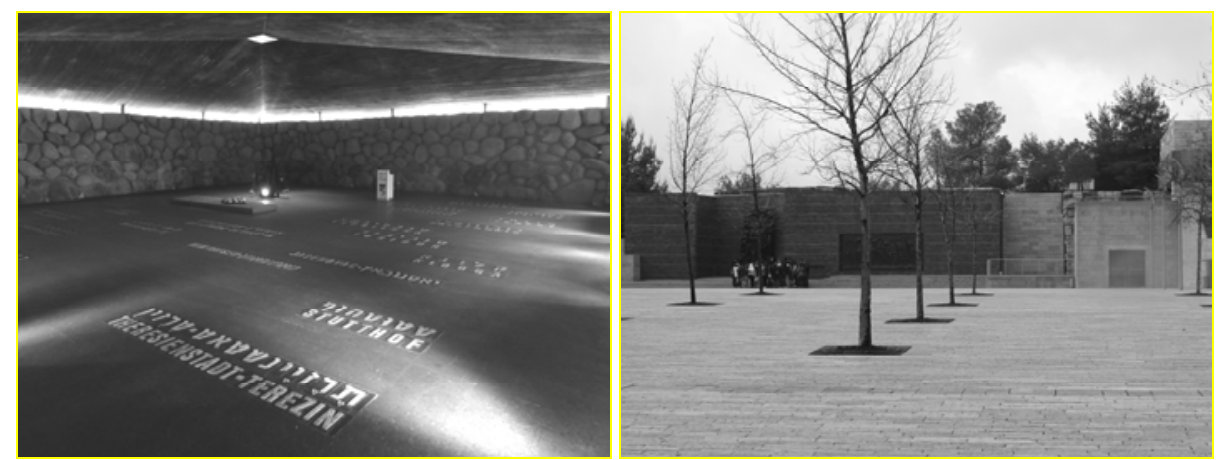

Fot. 15, 16. Muzeum Historii Holokaustu Yad Vashem w Tel Awiwie - Izrael (autor: S. Tanaś)

$\mathrm{Na}$ świecie muzea-pomniki zagłady i ludobójstwa są stosunkowo popularne, co wiąże się z zainteresowaniem społeczeństw własnym dziedzictwem i niejednokrotnie tragiczną historią. Najciekawsze tego typu obiekty, stanowiące jednocześnie ważny cel wycieczek turystycznych, to m.in. Muzeum Historii Holokaustu Yad Vashem w Tel Awiwie (Izrael) (fot. 15, 16), w Erewaniu Muzeum Ludobójstwa Ormian - Cicernakaberd (Armenia), pola śmierci - grupa kilkudziesięciu pomników, muzeów i parków pamięci w Kambodży (m.in. Tuol Sleng, Choeung Ek), Kigali Memorial Center 
w Rwandzie, na Bałkanach Cmentarz-Pomnik Ofiar Masakry w Srebrenicy w Potočarach. Muzeum Topografii Terroru w Berlinie (Topographie des Terrors) upamiętnia ofiary gestapo i SS. W Budapeszcie znajduje się Muzeum Represji Komunistycznych - Dom Terroru (Terror Háza Múzeum), poświęcone pamięci ofiar totalitaryzmu na Węgrzech w latach 1945-1956. Muzeum i pomnik "Czerwonego Terroru” (Red Terror Martyrs Memorial Museum) w Addis Abebie w Etiopii jest upamiętnieniem ofiar junty wojskowej z lat 1974-1978.

Muzeum techniki terrorystycznej Hezbollahu w Mlicie w Libanie (Hezbollah's Terror Tech Museum) jest nowoczesnym muzeum, będącym wizytówką działalności terrorystycznej i zbrojnej Hezbollahu. Muzeum Antyterrorystyczne w Denver w Stanach Zjednoczonych Ameryki (The Counterterrorism Education Learning Lab), otwarte w 2009 roku, jest nowoczesnym centrum poświęconym edukacji w zakresie działalności antyterrorystycznej. Muzeum "Narodowy Pomnik Oklahoma City” (Oklahoma City National Memorial) poświęcone zostało ofiarom zamachu bombowego w 1995 roku, w którym można oglądać oryginalne eksponaty świadczące o tragedii. W trakcie organizacji jest Muzeum-Pomnik Ofiar Zamachów z 11 września 2001 roku oraz 26 lutego 1993 roku na Światowe Centrum Handlu (WTC) w Nowym Jorku „The 9/11 Memorial”, które już jest jedną z głównych atrakcji turystycznych Nowego Jorku.

Nowoczesne, interaktywne muzea na miarę XXI wieku gromadzą pamiątki, artefakty dokumentują zdarzenia, upamiętniają ofiary, edukują, często przy wykorzystaniu najnowocześniejszych technik audiowizualnych. Właśnie ze względu na formę prezentacji oraz znaczenie edukacyjne muzea te są atrakcjami turystycznymi i wielokrotnie można je uznać za produkt turystyczny lub składowe większego produktu turystycznego.

Zainteresowanie obiektami dokumentującymi akty masowej zbrodni i terroryzmu wynika $z$ wielu potrzeb realizowanych $w$ trakcie wizyty. Najczęściej jest to połączenie poznania dziedzictwa i walorów kulturowych z poznaniem historycznych faktów; realizowane są motywy poznawczy i edukacyjny. Ale jednym z motywów jest również motyw emocji, zarówno $\mathrm{w}$ sferze sacrum - utożsamianie się z tragedią i cierpieniem ofiar, jak i profanum, czyli poczucie strachu i doznanie silnych bodźców psychicznych poprzez m.in. informację, obraz i dźwięk. Zainteresowanie śmiercią wynika z jej nieobecności w życiu codziennym przeciętnego turysty, przy jednoczesnej obecności w mediach, filmie, książkach, co wzbudza podświadome lub świadome zainteresowanie wielu osób tym tematem.

W Polsce brak jest, poza nielicznymi przykładami wystaw, obiektów dokumentujących współczesny terror, poza grupą miejsc upamiętniających ter- 
ror nazistowski i stalinowski (ŁABUSZEWSKI, red. 2012). Do grupy muzeów dokumentujących terror i ludobójstwo zaliczyć można muzea zorganizowane na terenach byłych obozów koncentracyjnych, zagłady i jenieckich. Najbardziej znanym w Polsce muzeum tego typu jest Państwowe Muzeum Auschwitz-Birkenau w Oświęcimiu, prezentujące nie tylko dowody ludobójstwa i zagłady ludności żydowskiej (Szoah), ale również metody terroru stosowane przez nazistów wobec ludności cywilnej.

Przeprowadzone badania nad motywami odwiedzin Muzeum Auschwitz-Birkenau (BERBEKA, red. 2012) potwierdzają stawiane wcześniej tezy. Połowa badanych przyznała, że muzeum jest jednym z punktów na trasie wycieczki turystycznej, wskazując na istotną atrakcyjność turystyczną miejsca i wagę obiektu jako produktu turystycznego, podnoszącą konkurencyjność turystyczną regionu małopolskiego. Większość respondentów, wypowiadając się na temat motywów wizyty, wskazała na potrzebę poznania historii obozu, pamięć o ofiarach i oddanie im hołdu. Natomiast po wizycie turyści mówili najczęściej o uczucie smutku, refleksji, wzruszenia, przy jednoczesnym wzbudzeniu szacunku dla życia, uwrażliwieniu na cierpienie ludzkie i ludobójstwo. Przytoczone wyniki badań potwierdzają, zarówno pedagogiczny, jak i andragogiczny efekt wizyty turystycznej w historycznej przestrzeni śmierci.

Należy zwrócić uwagę na fakt niejednorodności w ocenie podróży turystycznych do miejsc związanych z aktem terroru i ludobójstwa. Miejsca pamięci o komercyjnym charakterze wykorzystania skutków terroru i ludobójstwa do celów turystycznych nie zawsze oceniane są pozytywnie. Niestety, ruch turystyczny generuje również niepożądane dysfunkcje tanatoturystyki, które wynikać mogą z powierzchownego poznania przestrzeni śmierci, traktowanej jako niechciana, naładowana negatywnymi emocjami przestrzeń. Przestrzeń śmierci może być również uważana za miejsce kontaktu z popkulturowym wizerunkiem śmierci. Ruch turystyczny może prowadzić do nadmiernego i niepożądanego eksploatowania tej przestrzeni, jej uprzedmiotowienia i profanacji.

Z jednej strony terroryzm - jak wykazano wcześniej - jest barierą rozwoju przestrzeni turystycznej i gospodarki turystycznej. Wpływa na ograniczenie lub zahamowanie ruchu turystycznego na obszarach, gdzie dochodzi do aktów przemocy wobec turystów. Z czasem jednak zbrodnia i pamięć o ofiarach w wyniku działań dokumentujących i upamiętniających, kształtowania się przestrzeni pamięci, może stać się impulsem do odwiedzin memoratywnych, poznawczych i innych w ramach podróży turystycznych lub krajoznawczych. 



\section{ISTOTA TANATOTURYSTYKI}

Turystyka do miejsc dokumentujących i upamiętniających śmierć opisana została $\mathrm{w}$ literaturze angielskiej terminem thanatourism lub dark tourism (SEATON 1996, FOLEY, LENNON 1996, LENNON, FOLEY 2000). „Mroczna” turystyka, która jest konsekwencją globalnego rozwoju komunikacji i mediów oraz ewolucji potrzeb turystów, została zaklasyfikowana przez J. LENNONA i M. FOLEYA (2000) do turystyki kulturowej lub turystyki dziedzictwa (heritage tourism). $\mathrm{W}$ ten sposób $\mathrm{w}$ wyniku popytu na atrakcje turystyczne związane ze śmiercią, okrucieństwem i katastrofą organizowane są na całym świecie specyficzne produkty turystyczne. Jednocześnie J. LENNON i M. FOLEY (2000) zwracają uwagę na pewną sprzeczność wynikającą z przeciwstawiania sobie niepokoju i wątpliwości związanych $\mathrm{z}$ moralną interpretacją mrocznej turystyki z towarzyszącym jej pierwiastkiem edukacyjno-wychowawczym. Do mrocznej turystyki należy zaliczyć wizyty w miejscach, takich jak: pola bitew (historyczne i współczesne) oraz inne formy turystyki wojennej, muzea i wystawy muzealne prezentujące artefakty śmierci, cmentarze i groby, pomniki, więzienia, obozy koncentracyjne, miejsca katastrof, tragicznych wypadków, ataków terrorystycznych, zagrożenia życia oraz inne miejsca, które $\mathrm{w}$ tradycyjnej turystyce traktowane są jako nieturystyczne (TANAŚ 2006a, 2008b).

Thanatourism był po raz pierwszy zdefiniowany i opisany $w$ numerze „International Journal of Heritage Studies" w 1996 roku. Zawarte w nim artykuły opisują fenomen i etyczne problemy mrocznej turystyki (dark tourism) (FOLEY, LENNON 1996), historyczne podstawy, przemiany i główne formy tanatoturystyki (thanatourism) (SEATON 1996). Thanatourism to angielski termin, złożony z dwóch członów: Thanatos ( $\mathrm{w}$ mitologii greckiej Tanatos to uosobienie śmierci) i tourism (turystyka). A.V. SEATON (1996) zdefiniował tanatoturystykę jako:

Podróż do miejsca, całkowicie lub częściowo motywowaną potrzebą rzeczywistego lub symbolicznego „kontaktu” ze śmiercią, zwłaszcza, nagłą (brutalną). Podróż ta może być wywołana szczególnymi cechami osoby lub osób, których śmierć jest przedmiotem zainteresowania. 
A.V. SEATON (1996) uważal, że tanatoturystyka powinna być rozpatrywana raczej w aspekcie ludzkich zachowań i motywów wpływających na zaspokojenie określonych potrzeb, a nie $\mathrm{w}$ aspekcie charakterystyki celu podróży. Tanatoturystyka, która jest rodzajem turystyki poznawczej, opiera się na dwóch założeniach:

a) motywie - istnieje jeden konkretny motyw lub motyw jest jednym $\mathrm{z}$ wielu innych wpływających na potrzebę odwiedzenia „miejsca śmierci";

b) przedmiocie zainteresowania - zainteresowanie skoncentrowane jest na zmarłej osobie lub na szeroko pojętej śmierci.

Tanatoturystyka jest jedynie rodzajem turystyki poznawczej (kulturowej), a nie nadrzędnym w stosunku do niej zjawiskiem. Najczystszą kategorią tanatoturystyki jest podróż motywowana potrzebą odwiedzenia przestrzeni śmierci. Uczestnik podróży nie skupia się na zmarłym jako osobie o określonych cechach (choć jest to również możliwe), ale na miejscu upamiętniającym i dokumentującym śmierć, jej skalę lub formę (np. wizyty na cmentarzach, w katakumbach, w miejscach katastrof, w muzeach dokumentujących śmierć lub tortury). Podróż jest zatem podejmowana bez osobistej znajomości zmarłego. Odmienną kategorią tanatoturystyki jest podróż motywowana znajomością zmarłego, cenionego za jego zasługi.

A.V.SEATON $(1996,1999)$ wyróżnił pięć kategorii tanatoturystyki:

1. Podróże do miejsc publicznej śmierci lub miejsc będących jej świadectwem. Publiczne akty śmierci miały wielokrotnie charakter widowiska, np. walki gladiatorów, męczeńska śmierć chrześcijan i publiczne egzekucje. W ograniczonym stopniu współcześnie nadal obserwujemy potrzebę bycia świadkiem śmierci (np. zainteresowanie katastrofami i wypadkami komunikacyjnymi lub innymi zdarzeniami, konsekwencją których jest śmierć). Obserwowany jest ponadto ruch turystyczny na obszary działań wojennych, zamachów terrorystycznych czy naturalnych kataklizmów w celu bezpośredniego kontaktu z realną przestrzenią śmierci (ROJEK 1997, DUNKLEY, MORGAN, WESTWOOD 2007). Ta kategoria tanatoturystyki wiąże się przede wszystkim z ciekawością, która wpływa na powstanie potrzeby zobaczenia makabrycznego widoku z bliska, jak również często „bezpiecznego doświadczenia” czyjejś śmierci.

2. Podróże do miejsc, gdzie odnotowano lub odkryto fakt masowej lub indywidualnej śmierci. Mogą być to podróże do miejsc masowej śmierci (pól bitewnych, obozów zagłady, obozów koncentracyjnych, miejsc ludobójstwa, katastrof komunikacyjnych) lub indywidualnej śmierci (morderstw, tragicznych wypadków, egzekucji, tortur). 
3. Podróże do miejsc i pomników upamiętniających zmarlych. Są to wizyty na cmentarzach, w katakumbach, kryptach, przy pomnikach wojennych i mauzoleach. W tym przypadku ważna, choć niekonieczna, jest znajomość zmarlych, których groby są odwiedzane. Niektóre cmentarze są odwiedzane głównie ze względu na groby sławnych ludzi.

4. Podróże do miejsc niezwiązanych bezpośrednio ze zdarzeniem, prezentujących materialne dowody śmierci. Są to wizyty $\mathrm{w}$ obiektach muzealnych, na wystawach, gromadzących kolekcje narzędzi śmierci, tortur, dowody zbrodni, artefakty pogrzebowe i żałobne, mumie itp.

5. Podróże do miejsc inscenizacji śmierci. Są to wizyty na religijnych przedstawieniach śmierci, w tym najczęściej śmierci Chrystusa, inscenizacjach walk i bitew, aktów śmierci i cierpienia.

A.V. (2009) potwierdza, że choć tanatoturystyka ma długą historię, to na popularności zyskała dopiero $w$ ostatnich dwóch stuleciach. J. LENNON i M. FOLEY (2000) sugerują, że ważną rolę w popularyzacji tanatoturystyki odgrywają media, które dzięki globalnym technologiom komunikacyjnym upowszechniają wiedzę na temat śmierci traktowanej przez nie jako istotny element przekazu, widowisko, produkt, który musi zaistnieć w przekazie dziennikarskim i kulturze wizualnej. $\mathrm{W}$ ten sposób współczesny odbiorca przekazu medialnego obserwuje geograficzne zróżnicowanie kultury śmierci, co może prowadzić do pojawienia się potrzeby turystycznego odwiedzenia przestrzeni śmierci. A.V. SEATON $(1996,2009,2010)$ w swych pracach na temat tanatoturystyki wskazuje zarówno na jej behawioralny charakter, jak i rynkowy, konsumpcję i interpretację mrocznych atrakcji turystycznych organizowanych i zarządzanych według utartych schematów konstruowania produktu turystycznego. Uniwersalny charakter śmierci, ale jednocześnie jej różnorodność kulturowa oznacza, że tanatoturystyka ma potencjal, aby być jedną z najbardziej rozpowszechnionych rodzajów współczesnych podróży turystycznych.

P.R. STONE (2010) zwraca uwagę na grupę zagadnień wyjaśniających turystyczne wykorzystanie przestrzeni śmierci i mrocznych miejsc. Zalicza do nich:

- etykę (promocja tego typu miejsc i obiektów jako atrakcja turystyczna i ich komercjalizacja);

- informację i marketing (kreowanie przez media, reklamę przestrzeni śmierci, które nie są pierwotnie turystyczne, jako atrakcje warte zobaczenia); 
- interpretację i politykę (sposób interpretacji jest często podporządkowany celom politycznym);

- zarządzanie (sposób organizacji, udostępniania, wytwarzania produktu turystycznego);

- aspekty socjokulturowe i tanatologiczne (mnogość kontekstów ma wpływ na postawy społeczeństwa, w tym jego sekularyzację).

Autor dodałby jeszcze zagadnienia związane z geografią śmierci i zróżnicowaniem przestrzennym tanatoturystyki - geografią tanatoturystyki.

Tanatoturystyka obejmuje podróże turystyczne determinowane pośrednimi motywami, celami i przedmiotem zainteresowania. W literaturze klasyfikowane jako kategorie mrocznej turystyki (cierpienie, zagrożenie życia, katastrofa, strach, przerażenie, makabra, niewygoda, itp.) lub tanatoturystyki (śmierć, kultura śmierci, przestrzeń śmierci) są podróże obejmujące:

- war tourism (turystyka wojenna) i battlefield tourism (turystyka pól bitewnych) (CHRONIS 2005, GORDON 1998, HENDERSON 1997, 2000, LLOYD 1998, SEATON 1999, 2002a, SLADE 2003, SMITH 1996, 1998, WINTER 2011);

- phoenix tourism (turystyka do miejsc odradzających się) (CAUSEVIC, LYNCH 2011);

- Holocaust tourism (turystyka Holokaustu) (ASHWORTH 2002, BEECH 2000, LENNON, FOLEY 1999, KIDRON 2013, MILES 2002);

- genocide tourism (turystyka ludobójstwa) (BEECH 2009, WILLIAMS 2007, KNOX 2006, SHARPLEY 2012);

- slavery tourism (turystyka niewolnictwa) (DANN, SEATON 2001, RICE 2009);

- morbid tourism (patologiczna turystyka) (BLOM 2000);

- black spot tourism (turystyka mrocznych miejsc) (ROJEK 1993);

- cemetery tourism (turystyka cmentarna) (SEATON 2002b, TANAŚ 2008b);

- death tourism (turystyka śmierci) (ZIĘBIŃSKA-WITEK 2012);

- grief tourism (turystyka żalu) (DUNKLEY, MORGAN, WESTWOOD 2007, LEWIS 2008, KOWALCZYK 2009);

- ghost tourism (turystka miejsc upiornych, duchów) (SMOLEŃSKA 2012);

- terrorism tourism (turystyka terroru) (ADAMS 2003, KELLEY 1998, LiSLE 2013);

- prison tourism (turystyka więzienna) (STRANGE, KEMPA 2003).

Jak widać, głównym kryterium tych klasyfikacji jest przedmiot zainteresowania turysty lub motyw, jakim się kieruje. Brakuje w literaturze jednoznacznej typologii tanatoturystyki, która porządkowałaby kwestie motywu i celu podróży oraz walorów i atrakcyjności turystycznej. 
A.V. SEATON (2010) wykazuje, że mroczne oblicze turystyki może z powodzeniem kształtować postawy wobec śmierci w kontekście doświadczenia ze śmiercią innych, przy założeniu edukacyjnego charakteru podróży. R. SHARPLEY (2009) analizuje wpływ ideologii politycznej przemycanej w ramach mrocznej turystyki poprzez sposoby zarządzania i kontrolowania interpretacji cierpienia i śmierci w obiektach muzealnych. Na aspekt ten zwraca uwagę A. ZIĘBIŃSKA-WITEK $(2005,2012)$, analizując formy przedstawiania historii Holokaustu w muzeach i organizacji ekspozycji, nie zawsze spełniających kryterium autentyczności. Podobnie R. SHARPLEY i P.R. STONE (2009) - badali sposoby prezentacji tragedii i cierpienia w aspekcie komercjalizacji i popkulturowej wizualizacji, niejednokrotnie kiczowatej i nieadekwatnej do wagi problematyki. P.R. STONE (2009a) sugeruje, że etyczne dylematy dotyczące mrocznej turystyki wynikają z poszerzającej się sekularyzacji społeczeństwa i świeckiej interpretacji śmierci. Jednak w aspekcie socjalizacji mroczna turystyka może odgrywać rolę strażnika moralności i upowszechniania kulturowego dziedzictwa, pod warunkiem zachowania jej edukacyjnego charakteru. Tym samym mroczna turystyka, z wyłączeniem krytycznego popkulturowego jej wymiaru, kształtuje wśród turystów postawy wobec śmiertelności człowieka. Poprzez narrację w mrocznych atrakcjach turystycznych, miejscach pamięci, wystawach gromadzących artefakty kultury śmierci turysta, wykorzystując własne doświadczenie, może otrzymywać przekaz edukacyjny lub rozrywkowy kształtujący jego pokorę wobec śmierci (strach), pamięć historyczną, postawy moralne oraz myśl o własnej śmiertelności (STONE 2012).

\subsection{ATRAKCYJNOŚĆ TURYSTYCZNA KULTURY ŚMIERCI}

Atrakcyjność turystyczna jest czynnikiem decydującym o podejmowaniu podróży turystycznych. Można ją rozumieć jako grupę walorów turystycznych wspartą zagospodarowaniem turystycznym, dostępnością komunikacyjną i informacją turystyczną (WARSZYŃSKA, JACKOWSKI 1978, LIJEWSKI, MIKUŁOWSKI, WYRZYKOWSKI 2002, KRUCZEK, KUREK, NOWACKI 2007). Są to wszystkie obiekty materialne lub walory niematerialne, które stanowią przedmiot zainteresowania turystów. Szczegółową analizę atrakcji turystycznych przeprowadził M. NOWACKI (2012).

W typologiach walorów i atrakcji turystycznych bardzo rzadko odnaleźć można obiekty kojarzące się ze śmiercią. Najczęściej są to:

a) obiekty religijne - kościoły, kaplice, cmentarze; 
b) obiekty militarne - pola bitewne, obozy jenieckie, muzea militarne, pomniki poległych żołnierzy;

c) pomniki i muzea martyrologii - związane z masową eksterminacją, obozami koncentracyjnymi i ludobójstwem;

d) obiekty historyczne - zabytki architektury;

e) parki tematyczne - historyczne, nostalgii, horroru;

f) atrakcje kulturowe - jak muzea, wystawy, wydarzenia.

Pomimo braku literalnego wskazania w klasyfikacjach atrakcji i walorów turystycznych na wytwory kultury śmierci, należy pamiętać, że obiekty prezentujące, dokumentujące i upamiętniające śmierć oraz cierpienie człowieka od zarania dziejów stanowily atrakcję turystyczną. Egipcjanie podziwiali piramidy i uczestniczyli w festiwalach religijnych kultywujących śmierć. Grecy i Rzymianie uczestniczyli w krwawych igrzyskach i walkach gladiatorów. W okresie średniowiecza atrakcjami były obiekty sakralne i miejsca kultu religijnego. Wieki późniejsze upowszechniały wyjazdy do wykopalisk archeologicznych. W wieku XVIII prywatne kolekcje osobliwości przyrodniczych, w tym preparowane ciała i narządy ludzkie, były udostępniane szerszej publiczności (np. Muzeum Kunstkamera w St. Petersburgu) (fot. 17).

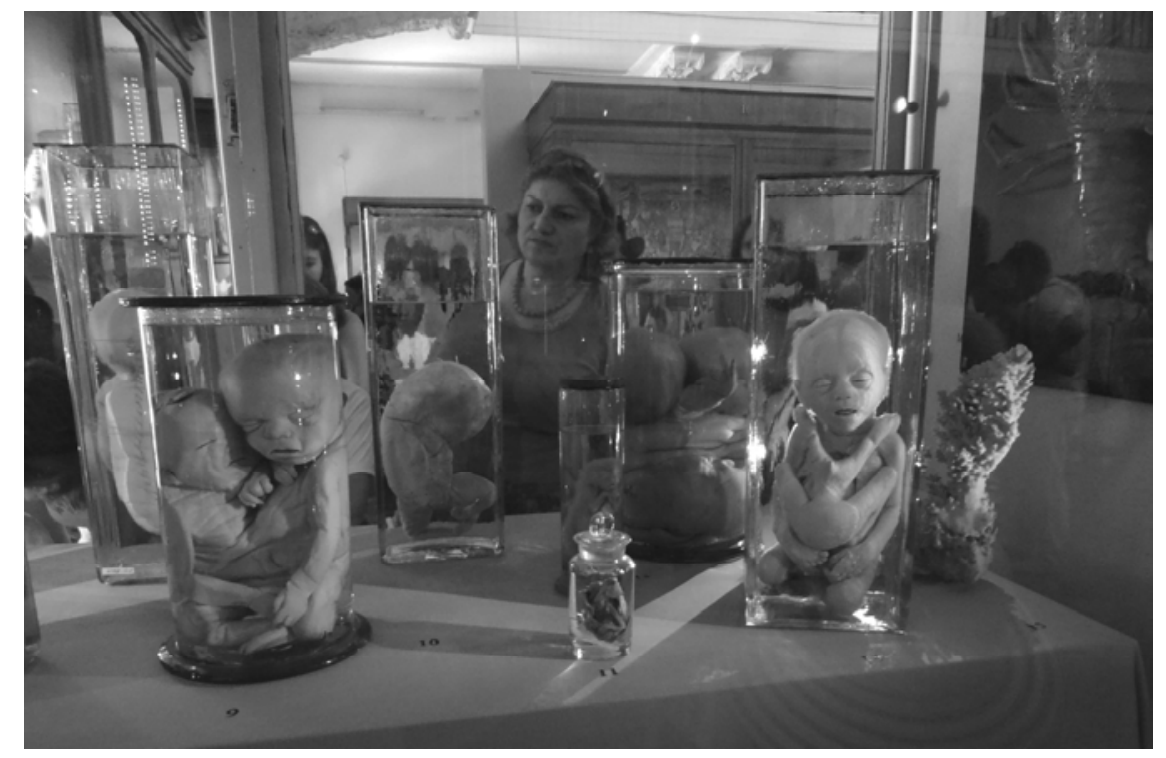

Fot. 17. Muzeum Kunstkamera w St. Petersburgu - Rosja (autor: Sławoj Tanaś)

XIX stulecie przyniosło rozwój muzealnictwa i popularyzację kolekcji artefaktów związanych ze śmiercią i pogrzebem. Upowszechniały się cmen- 
tarze będące galeriami rzeźby sepulkralnej. Pola bitew, katastrof i tragedii ludzkich stały się wybitnymi atrakcjami turystycznymi. Powstawały atrakcje o sztucznym charakterze, jak Muzeum Figur Woskowych Madame Tussauds w Londynie, gdzie pierwszymi eksponatami były głowy straconych podczas rewolucji francuskiej. Zaczęły powstawać atrakcje, w których próbowano przedstawiać autentyczną kulturę. Wydłużała się lista obiektów zyskujących zainteresowanie turystów. Pojawily się na niej krypty, ossuaria, obozy koncentracyjne, miejsca masowych mordów i inne obiekty historycznie związane ze śmiercią.

Jednym z pierwszych badaczy, który sformułował teorię powstania atrakcji turystycznej był D. MACCANNELL (2002). Wyróżnił on pięć faz formowania się atrakcji turystycznej (NOWACKI 2012, s. 43-44):

1) faza nazwania - miejsce lub obiekt zostaje wyróżniony spośród innych;

2) faza ujęcia w ramy i podniesienia - obiekt zostaje udostępniony do zwiedzania;

3) faza umieszczenia na ołtarzu - umieszczenie obiektu w szczególnie eksponowanym miejscu wśród innych obiektów;

4) faza reprodukcji mechanicznej - powielanie obiektu i reprodukcja mająca na celu promocję i stymulację przyjazdów;

5) faza reprodukcji społecznej - przyjmowanie nazewnictwa od znanych atrakcji.

Etapy rozwoju atrakcji turystycznej prześledził na przykładzie Waterloo A.V. SEATON (1999). A. KOWALCZYK (2009) założył z kolei przejście zasobów turystycznych do atrakcji poprzez wzrost zagospodarowania turystycznego, przy obecności turystów w trakcie tego procesu (zasoby turystyczne, walory turystyczne, atrakcje turystyczne, produkty turystyczne). Atrakcje turystyczne ewoluują według określonego cyklu życia nawiązującego do cyklu życia obszaru turystycznego R. BUTLERA (1980). Fazy te, to kolejno: odkrycie atrakcji, wprowadzenie na rynek turystyczny, rozwój, umocnienie pozycji, stagnacja rozwoju, odmłodzenie lub upadek (NoWACKI 2012, s. 45).

Elementy kultury śmierci również ze względu na zainteresowanie nimi turystów mogą osiągnąć miano atrakcji turystycznej, choć przez wielu określenie to będzie negowane. Przykładami polskich atrakcji turystycznych, będących obiektami związanymi ze śmiercią, są Państwowe Muzeum Auschwitz-Birkenau w Oświęcimiu, Kaplica Czaszek w Czermnej (Kudowa Zdrój), Cmentarz na Pęksowym Brzyzku w Zakopanem, Muzeum Martyrologii Wsi Polskich w Michniowie, Muzeum Horroru w Wojnowicach.

Odwiedzanie atrakcji jest formą swoistego obrzędu poszukiwania autentyczności (MACCANNELL 2002). Turysta może odczuwać obowiązek odbycia 
podróży do miejsc, które naznaczone zostało przez społeczeństwo w kategoriach atrakcyjności. A. WIECZORKIEWICZ (2008) przeanalizowała proces zwiedzania przestrzeni zamachu terrorystycznego z 11 września 2001 roku na World Trade Center w Nowym Jorku. Turysta przybywa do atrakcji z oczekiwaniami doznania określonych uczuć. Mając wyrobioną wcześniej koncepcję doświadczenia próbuje rozpoznać widok. Po rozpoznaniu widoku poszukuje znaczeń, które pozwolą na interpretację. Aby doświadczenie turystyczne, które jest efektem zwiedzania zostało dopełnione, musi nastąpić relacja pomiędzy oznacznikiem (znaczeniem) a zwiedzanym obiektem. Interpretacja znaczeń jest uzależniona od czasu, doświadczenia czy wiedzy turysty. Proces zwiedzania zamyka się po rozpoznaniu atrakcji. Zwiedzanie jest więc procesem wizualnym, budującym kolejne doświadczenia i przeżycia (WIECZORKIEWICZ 2008) (rys. 30).

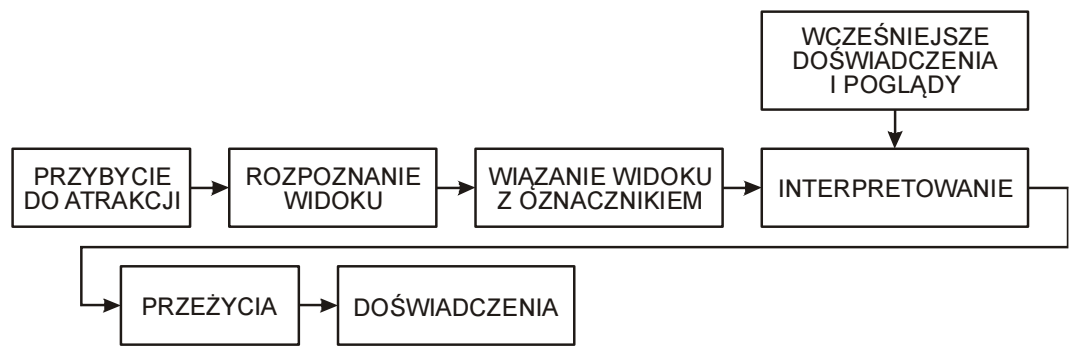

Rys. 30. Proces zwiedzania atrakcji turystycznej (NOWACKI 2012, s. 74)

Obiekty i miejsca związane ze śmiercią podlegają szczególnemu procesowi poznania i interpretacji, uzależnionemu nie tylko od wiedzy i doświadczenia turysty, ale również od jego światopoglądu, wiary i tolerancji. Ten sam obiekt może być interpretowany w różny sposób, może zaspokajać różne potrzeby, może w końcu generować różne, skrajnie odmienne reakcje.

Według J. URRY'EGO (2007), najważniejszym elementem aktywności turystycznej jest patrzenie, poszukiwanie miejsc różniących się od widzianych na co dzień. Z pewnością takimi miejscami współcześnie są przestrzenie śmierci. Potencjalne obiekty, takie jak atrakcje, aby zdobyć zainteresowanie turysty muszą wnosić jakąś różnicę, być niecodzienne. Mogą angażować inne zmysły niż na co dzień lub angażować je mocniej (NOWACKI 2012). Przedmiotem zainteresowania turysty są przede wszystkim obiekty wyjątkowe, unikatowe, np. muzea horroru czy miejsca prezentujące mumie. Inną cechą miejsca atrakcyjnego jest typowość, określone znaki wyróżniające miejsce lub obiekt spośród innych, np. typowy nagrobek, typowa dekoracja. Kolejną cechą jest 
niezwyczajność tego, co było kiedyś zwyczajne. Przykładem mogą być sale tortur, muzea więziennictwa, obrzędów pogrzebowych. Turystyczny widok, wyróżniający się z życia codziennego historyczną, kulturową czy przyrodniczą niezwykłością (ROJEK 1997, s. 52) jest konsekwencją percepcji miejsca turystycznego. C. Rojek (1997; za: PODEMSKI 2004, s. 89) przytacza przykład kreacji widoku poprzez społeczną mitologizację (fot. 18, 19). Film Lista Schindlera S. Spielberga stał się powodem do organizowania wycieczek po krakowskim Kazimierzu i po okolicy byłego obozu koncentracyjnego w Płaszowie, wykreowanego jako miejsce zagłady Żydów. Film pomija martyrologię Polaków stanowiących połowę więźniów obozu w Płaszowie. Nie historia, lecz mit kreuje turystyczny obraz.

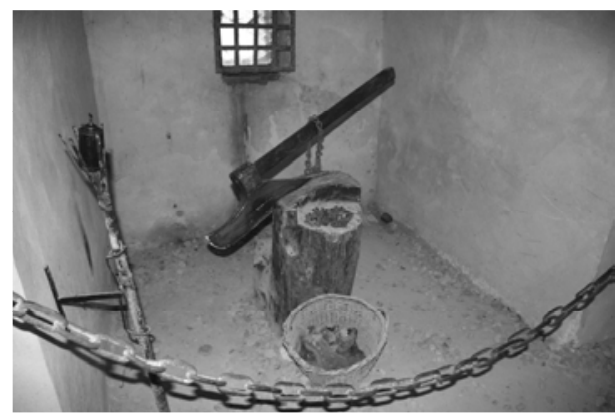

Fot. 18. Sala tortur w podziemiach zamku w Krasiczynie (autor: S. Tanaś)

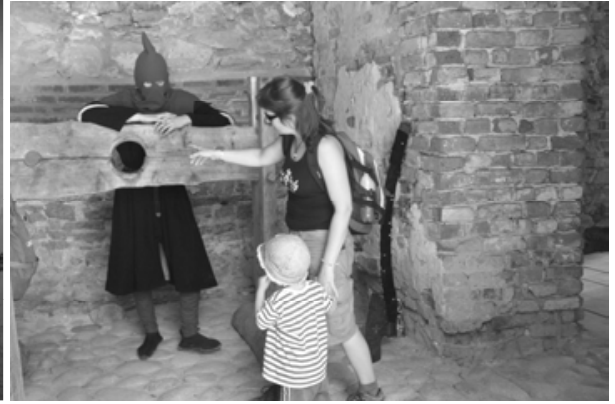

Fot. 19. Sala tortur na zamku w Niedzicy (autor: S. Tanaś)

W zwiedzaniu atrakcji turystycznych zorganizowanych $\mathrm{w}$ oparciu o śmierć człowieka znaczenie mają motywacje, bariery i zachowania (Davies, Prentice 1995, za: NOWACKI 2012, s. 80). Proces podjęcia decyzji o podróży do przestrzeni śmierci można podzielić na kilka etapów. Etap pierwszy dotyczy powstania motywacji po podjęciu aktywności; motywacja może być zarówno pozytywna, jak i negatywna. Etap drugi obejmuje istniejące w rzeczywistości bariery lub bariery fikcyjne oraz sposoby ich pokonywania. Etap trzeci to zachowania turysty wyrażające się aktywnością w zakresie odwiedzenia atrakcji lub jej brakiem. Najczęściej miejsca związane ze śmiercią generują motywacje negatywne, następnie kreację barier nie do pokonania, a w konsekwencji niezwiedzanie lub zwiedzanie bardzo okazjonalne przestrzeni śmierci. W przypadku motywacji pozytywnych zwiedzający pokonuje bariery lub ich nie spostrzega, konsekwencją czego jest zwiedzanie atrakcji turystycznych opartych na kulturze śmierci (rys. 31). 


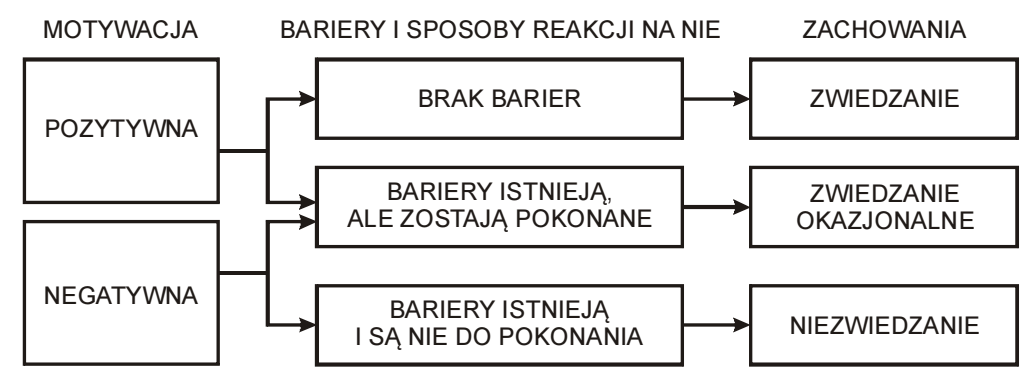

Rys. 31. Model i bariery zwiedzania atrakcji Źródło: opracowanie własne na podstawie A. Davies i R. Prentice

(1995; za: NOWACKI 2012, s. 81)

Wbrew wielu negatywnym ocenom tanatoturystyki, przestrzeń śmierci i kultura śmierci jest $\mathrm{w}$ wielu przypadkach oceniana jako turystycznie atrakcyjna. V. SMITH (1998) wręcz sugeruje, że miejsca związane z wojną prawdopodobnie stanowią "największą pojedynczą kategorię atrakcji turystycznych na świecie" (HENDERSON 2000, STONE 2006). Atrakcje związane z wojną, choć same w sobie są zróżnicowane, stanowią podzbiór atrakcji turystycznych związanych ze śmiercią i cierpieniem (DANN 1998).

Do atrakcji turystycznych bazujących na rozrywce, np. „fabryki mrocznej zabawy" (STONE 2006), do których zaliczymy Muzeum Horroru w Wojnowicach czy obiekty rozrywkowe należące do Merlin Entertainments Group, z których The Dungeons (Lochy) stanowią grupę ośmiu "fabryk rozrywki” w Europie. Turysta odwiedzając te obiekty może zagłębić się w najbardziej okropnej historii Europy oraz, poprzez połączenie historii, horroru i humoru, przenieść się w świat makabrycznych wydarzeń i scenerii (fot. 20, 21).

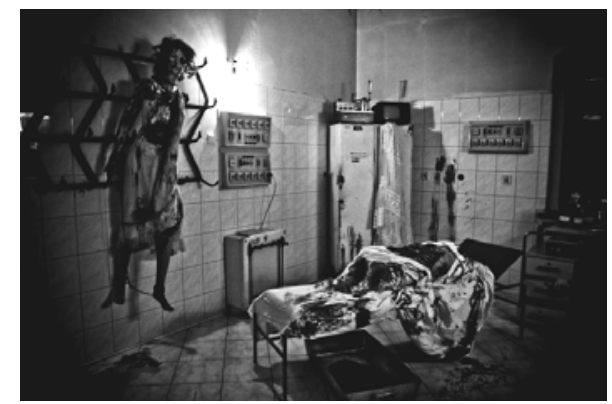

Fot. 20. Muzeum Horroru w Wojnowicach

Źródło: materiały informacyjne muzeum

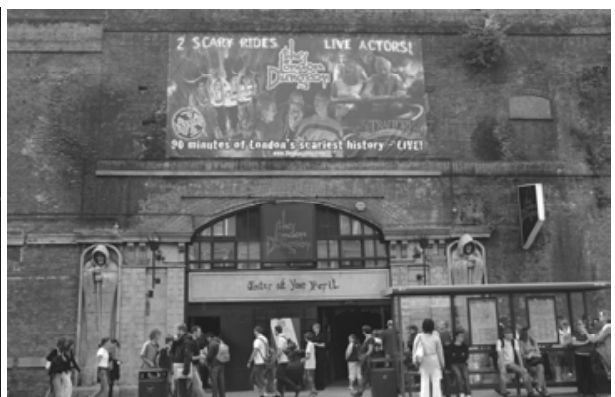

Fot. 21. The London Dungeon Źródło: materiały informacyjne MEG 
Pozostałe materialne elementy kultury śmierci, takie jak ossuaria, krypty, cmentarze, grobowce, artefakty pogrzebowe oraz obrzędy, rytuały i zwyczaje, stanowią atrakcje turystyczne traktowane jako ciekawe i oryginalne wytwory kultury i cenne dziedzictwo.

Kultura śmierci nacechowana jest emocjami, które mają wielowymiarowy charakter. Tanatoturystyka i mroczna turystyka, jak każdy inny rozdaj turystyki, funkcjonuje $\mathrm{w}$ oparciu o atrakcje turystyczne i zagospodarowanie turystyczne, choć to ostatnie nie jest warunkiem koniecznym, aby mówić o atrakcyjności miejsca.

Turystyczna „konsumpcja” kultury śmierci w perspektywie wyjaśnień tanatologicznych podjęta została $\mathrm{w}$ wielu publikacjach brytyjskich (m.in. STONE 2005, 2009b, 2012, STONE, SHARPLEY 2008). Badania te opierają się na tanatologicznym paradygmacie relacji między socjokulturowymi aspektami

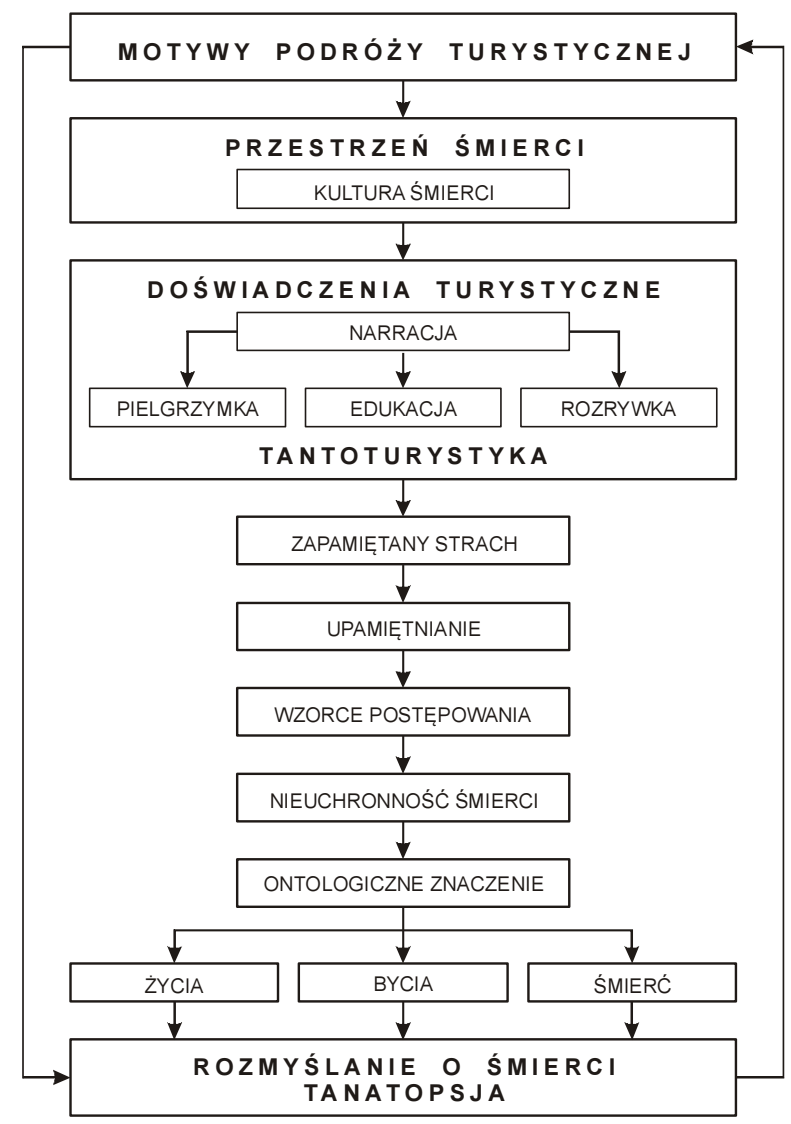

Rys. 32. Konsekwencje doświadczenia turystycznego w przestrzeni śmierci Źródło: opracowanie własne na podstawie P.R. STONE (2012) 
śmierci i śmiertelności a potencjalnej roli turystyki w relacjach między żywymi a śmiercią i umieraniem. Istotą doświadczenia turystycznego przestrzeni śmierci jest sposób jej narracji uzależniony od motywów odwiedzin. W zależności od tego, czy jest to motyw edukacyjny, pielgrzymkowy czy rozrywkowy turysta zinterpretuje przestrzeń i kulturę śmierci odmiennie, ale pobudzony zostanie w różnym stopniu i w różny sposób proces rozmyślania o śmierci (rys. 32).

Tanatoturystyka jest pomostem pomiędzy śmiercią a życiem, pomiędzy umarłymi a żywymi. Turysta jest zmuszony do kontemplacji śmierci, co ma wymiar nie tylko religijny, ale również, a może przede wszystkim, społeczny. Śmierci możemy się bać, możemy ją szanować, możemy ją rozumieć, ale również możemy się $\mathrm{z}$ niej śmiać. Turystyka jest $\mathrm{w}$ stanie wygenerować każdy z tych skutków, w zależności od potrzeb i zasobów, jakimi dysponują zarówno turyści, jak i organizatorzy atrakcji turystycznych. Z jednej strony nieobecność śmierci w prywatnym życiu ze względu na redukcję sacrum, laicyzację społeczeństwa zachodniego, medykalizację procesu umierania i komercjalizację śmierci; $\mathrm{z}$ drugiej strony wszechobecność śmierci w kulturze popularnej i mediach.

Paradoksalnie tanatoturystyka odgrywa istotną rolę w relacjach między sacrum a profanum śmierci, jest czynnikiem powodującym zainteresowanie śmiercią w różnych aspektach jej rozumienia i postrzegania, zarówno jako element edukacyjny, jak i pogłębiający tabu śmierci realnej poprzez tworzenie substytutu, materiału zastępującego prawdziwy, realny kontakt z faktem nieuchronnej śmierci. Tanatoturystyka pozwala na zrewidowanie naszego podejścia do śmierci, stymulując potrzebę kontemplacji śmierci (tanatopsji) od pierwotnego poczucia strachu i odrazy do zrozumienia i przygotowania się na śmierć. Również turystyczne atrakcje opierające się na fenomenie śmierci, poprzez kontemplację, edukację, upamiętnienie lub rozrywkę, mogą zmniejszać obawy przed śmiercią (STONE 2012).

Turysta, w zależności od potrzeb i motywów podróży spotka się z aspektem śmierci w bardzo wielu miejscach i w różny sposób. Turystyczne zainteresowanie śmiercią wynika najczęściej z odmienności kulturowej mającej wpływ na zróżnicowanie percepcji śmierci przez turystę $\mathrm{w}$ aspekcie religijnym, obrzędowym (w tym formy kultu i upamiętnienia zmarłego), wiary (kultura ludowa, życie pozagrobowe, duchy, siły nadprzyrodzone, fantazmaty, nieśmiertelność, reinkarnacja, legendy, kult śmierci), traktowania zwłok (sposób grzebania, kremacja, mumifikacja, kanibalizm, magazynowanie szczątków), sposobu wyrażania emocji wobec śmierci (powaga, smutek, strach, szacunek, zabawa). 


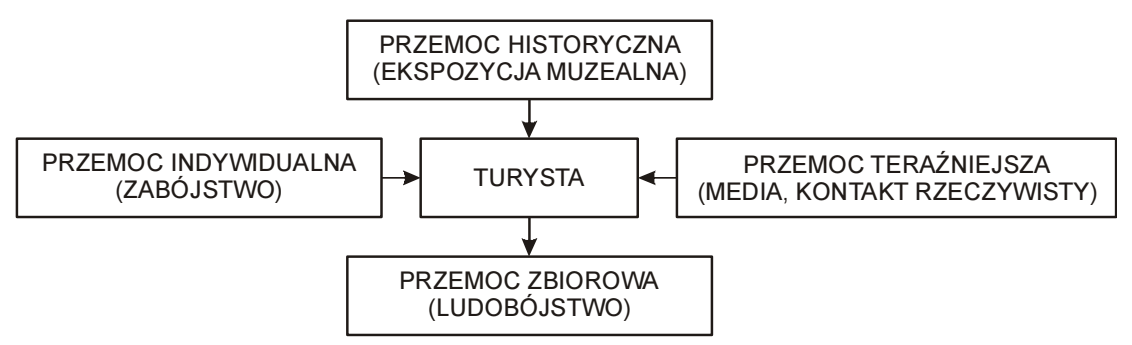

Rys. 33. Rodzaje przemocy oddziałujące na turystę Źródło: opracowanie własne

W kulturze śmierci, z jaką spotyka się turysta ma też swoje miejsce przemoc. Przemoc, konsekwencją której jest cierpienie lub śmierć, eksponowana jest $\mathrm{w}$ wielu miejscach lub obiektach dokumentujących i upamiętniających ją (rys. 33). Turysta lub pielgrzym spotyka się z czterema rodzajami przemocy, wyodrębnionymi według kryterium czasu i skali:

- przemoc historyczna dokumentowana w muzeach poprzez zgromadzone artefakty; ma charakter edukacyjny lub rozrywkowy;

- przemoc teraźniejsza dokumentowana przez media oraz oddziałująca bezpośrednio na turystę; ma charakter bezpośredniego doświadczenia;

- przemoc zbiorowa dokumentowana w muzeach i miejscach pamięci; ma charakter memoratywny (upamiętniający) i prewencyjny;

- przemoc indywidualna dokumentowana w muzeach i przestrzeni pamięci; ma charakter memoratywny i nostalgiczny.

\subsection{MOTYWY PODRÓŻY TANATOTURYSTYCZNYCH}

Podróż, według J. CLIFFORDA (1997), to mniej lub bardziej dobrowolna praktyka opuszczania "domu” w celu udania się do jakiegoś odmiennego miejsca. Takie przemieszczanie może mieć cel materialny, duchowy lub naukowy (PODEMSKI 2004). Podróż jest więc mobilnością przestrzenną człowieka, której rezultatem jest zmiana środowiska geograficznego, społecznego i kulturowego. Podróż tanatoturystyczną rozumieć należy jako podróż motywowaną zainteresowaniem kulturą śmierci, jej materialnym i duchowym dziedzictwem wynikającym z potrzeb społecznych i kulturowych, w tym np. poznawczych, edukacyjnych, wychowawczych, religijnych, patriotycznych czy rozrywkowych. 
We współczesnej literaturze zachowanie turystów traktowane jest jako rezultat działania dwu podstawowych grup czynników:

- wypychających turystów z miejsc stałego pobytu (zamieszkania);

- przyciągających ich do miejsc docelowych - turystycznych (MAZURKIEWICZ 2007, s. 101).

To, jak zachowuje się turysta, zależy od:

1) przyczyn wewnętrznych, osobowych, związanych $z$ nim samym, wypychających go $\mathrm{z}$ miejsca stałego pobytu i zapoczątkowujących zjawisko podróży turystycznej;

2) przyciągającej sily walorów turystycznych, odmiennej dla różnych miejsc i powodującej, że turysta wybiera jedne miejsca, nie poświęcając lub poświęcając niewiele uwagi innym.

Opierając się na przemyśleniach L. MAZURKIEWICZA (2007, s. 106), autor rozpatruje proces selekcji miejsca podróży tanatoturystycznej i jego wyboru. $\mathrm{Na}$ pierwszym etapie tego procesu turysta wyodrębnia trzy zbiory miejsc (atrakcji), mając na uwadze własne potrzeby, motywy i cele, jakie chce osiągnąć:

1) miejsca, których z różnych powodów nie akceptuje; do nich należą najczęściej miejsca nacechowane negatywnymi wartościami, w tym śmiercią i zagrożeniem;

2) miejsca, które traktuje obojętnie, głównie z powodu niedostatecznej informacji o ich walorach turystycznych; w tej grupie są np. cmentarze, które turysta traktuje jako przestrzenie nieturystyczne;

3) miejsca, które traktuje jako prawdopodobne miejsca docelowe, które chciałby ze względu na określone powody (motywy) odwiedzić, takie jak np. miejsca szokujące, niedostępne, wartościowe pod względem artyzmu, historyczne, rozrywkowe.

$\mathrm{Na}$ drugim etapie turysta rozpatruje jedynie zbiór miejsc docelowych, dzieląc go $\mathrm{z}$ jednej strony na zbiór miejsc, $\mathrm{w}$ stosunku do których nie zamierza podejmować podróży z różnych przyczyn (wynikających $\mathrm{z}$ aktualnych barier), oraz zbiór miejsc, w odniesieniu do których decyduje się na zbieranie informacji. Na trzecim etapie selekcji, opierając się na zebranej informacji, wyodrębnia miejsca docelowe stanowiące cel jego podróży.

W przypadku podróży tanatoturystycznej wielokrotnie pojawia się pierwiastek przypadkowości. Turysta może na swej drodze napotkać obiekt, który wcześniej nie funkcjonował w jego świadomości jako turystyczny, jednak ze względu na jego odmienność, oryginalność lub ciekawość stanie się pośrednim celem podróży. Nie tylko informacja i dotychczasowe doświadczenie mają wpływ na motywację turystyczną, równie ważne są cechy psychiczne i osobowe potencjalnego turysty. Stanowią one filtr, przez który 
przepływa informacja wyjściowa i turystyczne doświadczenie. Przyszły turysta ocenia jedno i drugie z punktu widzenia systemu wartości, jakie uznaje, swoich przekonań i postaw, cech osobowych oraz korzyści, których spodziewa się po walorach oferowanych przez poszczególne miejsca. $W$ efekcie otrzymuje obraz tych miejsc, określony w kategoriach swoich potrzeb i oczekiwań, i dopiero na podstawie tego obrazu może pojawić się, lub też nie, bodziec (motywacja) do podjęcia starań, aby wybrać się w podróż (MAZURKIEWICZ 2007, s. 108). Prawdopodobieństwo pojawienia się motywacji zależy od tego, w jakim stopniu pozytywna okazała się zawartość otrzymanego obrazu (rys. 34).

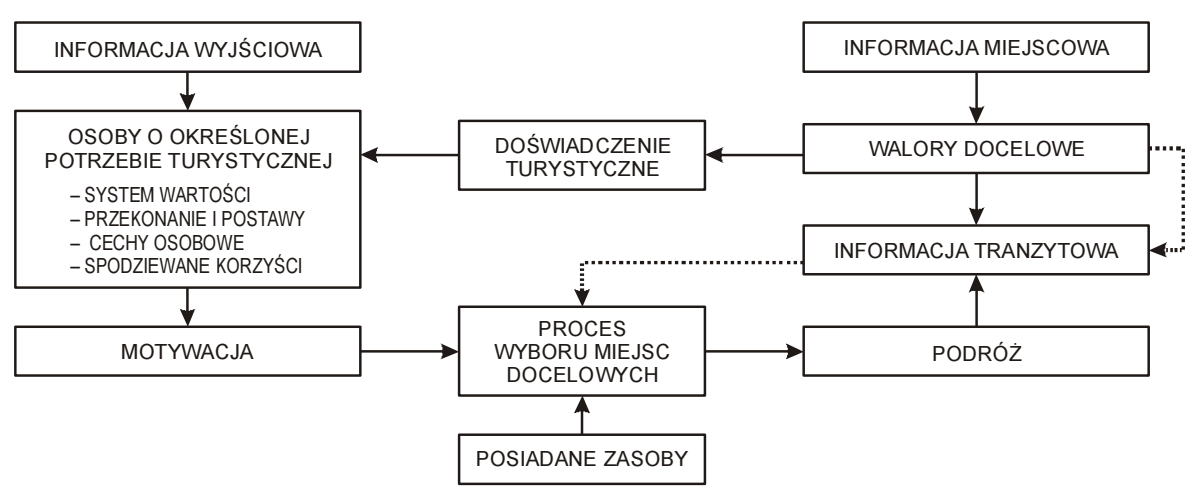

Rys. 34. Model przestrzennego zachowania turysty

Źródło: L. MAZURKIEWICZ (2007, s. 108)

Przestrzeń śmierci i wytwory kultury śmierci nie należą do typowych celów turystycznych. Wielokrotnie wzbudzają niechęć, odrazę i opór. Człowiek z natury $\mathrm{w}$ trakcie podróży turystycznych odwiedza miejsca nacechowane pozytywnie. Wielokrotnie wspominany już w książce przykład Państwowego Muzeum Auschwitz-Birkenau w Oświęcimiu wskazuje nie tylko na potrzebę odwiedzenia miejsca pamięci, ale również na niechęć osób słabszych psychicznie do miejsc nacechowanych negatywnymi walorami, nieakceptujących zaburzania właściwego rytmu turystycznej wycieczki. Oczywiście odmiennie należy traktować podróże o motywach poznawczych, edukacyjnych i memoratywnych.

Studia nad motywami podróży leżą w gestii psychologii i socjologii. Brak jest narzędzi pozwalających w sposób pewny określić motywy, jakimi jednostka kieruje się podejmując określone zachowania (PRZECŁAWSKI 1996, s. 40). Motywy odwiedzania przestrzeni śmierci zostały przeanalizowane 
przez autora (TANAŚ 2008b), który wyróżnił dwie grupy motywów: sacrum i profanum (rys. 35).

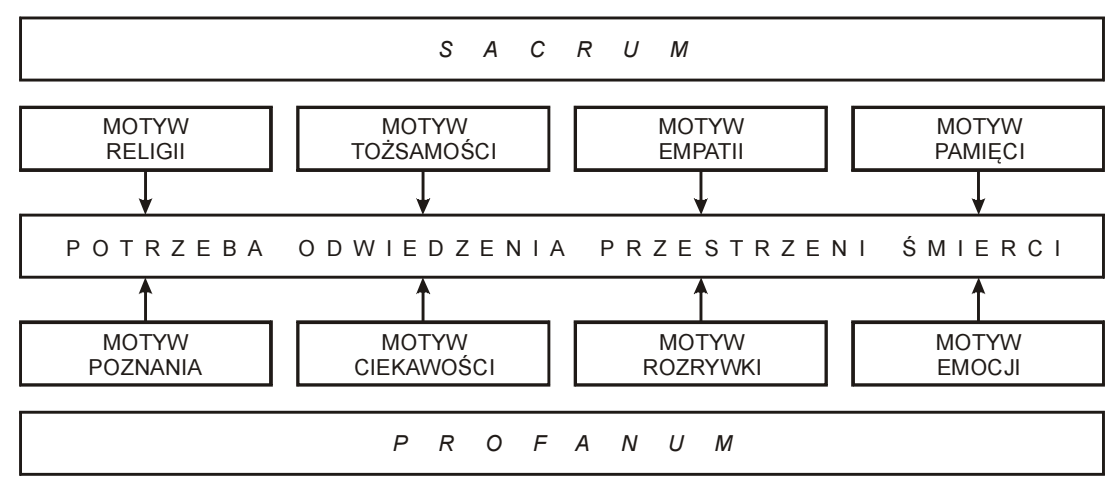

Rys. 35. Motywy odwiedzania przestrzeni śmierci

Źródło: S. TANAŚ (2008b), zmienione

W grupie motywów odwołujących się do sacrum przestrzeni śmierci wyróżnić można:

1) motyw religii - wynikający z potrzeb religijnych, który wiąże się ściśle z kultem zmarlego i relikwii, czego przejawem są pielgrzymki do miejsc śmierci, grobów i przechowywania relikwii;

2) motyw tożsamości - będący efektem poszukiwania przodków, odkrywania historii, kształtowania tożsamości rodzinnej, lokalnej czy narodowej; jest ściśle związany z turystyką sentymentalną, zwaną też turystyką korzeni (roots tourism);

3) motyw empatii - wynikający z potrzeby łączenia się w bólu z bliskimi zmarłych; są to podróże do grobów ofiar wojen, ludobójstwa, katastrof oraz miejsc dokumentujących tragiczne zdarzenia;

4) motyw pamięci - będący efektem podtrzymywania pamięci po zmarłym lub o wydarzeniu, najczęściej polegający na składaniu hołdu i odwiedzaniu przestrzeni pamięci (pomników, cmentarzy, miejsc pamięci).

W grupie motywów odwołujących się do sfery profanum przestrzeni śmierci znajdują się:

1) motyw poznania - kształtujący potrzebę poznania historii, kultury, przestrzeni lub zmarłego;

2) motyw ciekawości - przejawia się chęcią zobaczenia i zapamiętania miejsca lub zdarzenia niezwykłego, niecodziennego, unikatowego;

3) motyw rozrywki - tabu śmierci wywołuje potrzebę fikcyjnego kontaktu z nią poprzez zabawę; 
4) motyw emocji - motyw wynikający z globalnego rozwoju popkultury i kultury masowej; potrzeba doznania emocji strachu, przerażenia, odrazy, poprzez fikcyjny kontakt z cierpieniem i śmiercią.

K. PRZECŁAWSKI (1996) wyróżnił wiele motywów podróży, w grupie których można wyodrębnić mogące determinować podróże tanatoturystyczne. Autor zalicza do nich: motyw poznania kultury i życia społecznego (wejście w kontakt z kulturą i ludźmi), motyw opuszczenia środowiska lokalnego, społecznego (potrzeba kontaktu z odmiennym środowiskiem), motyw wyjazdu w określonej grupie ludzkiej (potrzeba kontaktu z grupą ludzi, mających podobne potrzeby, np. z pielgrzymami), motyw zaspokojenia potrzeb estetycznych i emocjonalnych (potrzeba przeżycia przygody lub ryzyka, kontaktu ze zwyczajami), motyw zaspokojenia potrzeb twórczych (praca na rzecz ludności odwiedzanego obszaru, praca artystyczna, naukowa) oraz motyw kultu (realizacja potrzeb religijnych i patriotycznych).

P.R. STONE (2010) przeprowadził badania w czterech wybranych obiektach, które można zaklasyfikować jako obiekty tanatoturystyczne. Były to The London Dungeon i Body Worlds Exhibition w Londynie, Tribute WTC Visitor Centre w Nowym Jorku oraz Państwowe Muzeum Auschwitz-Birkenau w Oświęcimiu. Pierwsze dwa obiekty można zaliczyć do atrakcji popkulturowych, dwa następne do obiektów pamięci. Zgodnie z oczekiwaniami, odpowiedzi wskazujące na motyw odwiedzin obiektu były zróżnicowane. Wspólnym motywem było poznanie i zrozumienie istoty prezentowanej śmierci ofiar.

Na pytanie o motywy odwiedzenia w przypadku The London Dungeon przeważały odpowiedzi wskazujące na rozrywkę i zabawę (73\%) oraz edukację w zakresie makabrycznych wydarzeń $(42 \%)$ oraz sposobów tortur i śmierci. Analizując odpowiedzi dotyczące wystawy Body Worlds, prezentującej spreparowane ciało ludzkie, stwierdzono, że $73 \%$ odpowiedzi wskazywało na zaspokojenie ciekawości, a $62 \%$ na motywy edukacyjne i naukowe oraz poznanie anatomii czlowieka. Tribute WTC Visitor Centre odwiedzano w celu oddania hołdu i szacunku ofiarom (56\%) oraz w celach edukacyjnych (52\%), poznania faktów historycznych. Muzeum Auschwitz-Birkenau odwiedzano $\mathrm{z}$ kolei $\mathrm{w}$ celach edukacyjnych, poznania historii (58\%) i zrozumienia Holokaustu, dla oddania hołdu ofiarom (40\%) oraz poznania życia ofiar zagłady (39\%). Badania wskazały, niezależnie od interpretacji miejsca, na pierwszorzędne znaczenie doświadczenia i przeżyć indywidualnych w kształtowaniu postaw i wiedzy dotyczącej śmiertelności człowieka oraz kreowania indywidualnej postawy wobec śmierci w przestrzeni turystycznej. 

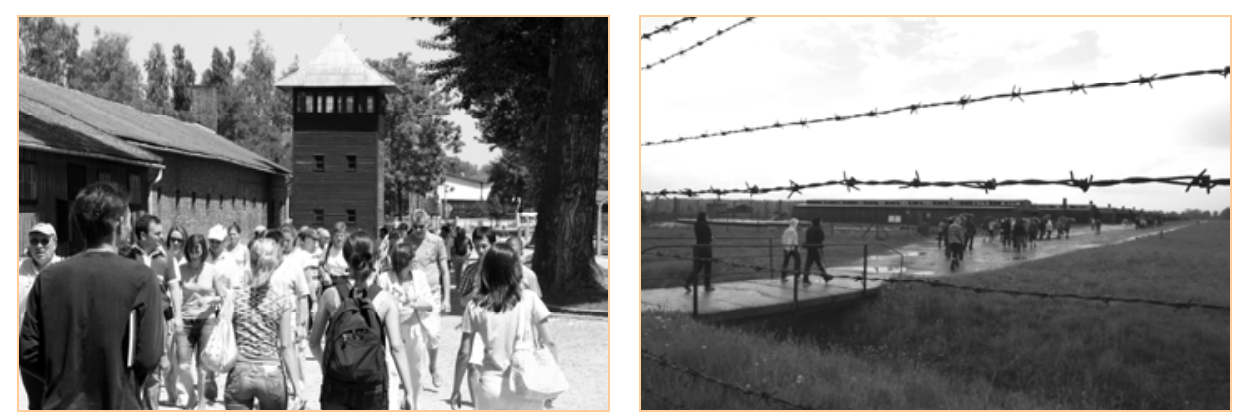

Fot. 22, 23. Turyści na terenie Państwowego Muzeum Auschwitz-Birkenau w Oświęcimiu (autorzy: S. Tanaś, R. Wiluś)

J. BERBEKA (red. 2012) przeprowadziła badania nad motywami odwiedzin Muzeum Auschwitz-Birkenau, które potwierdzają badania P.R. STONE'A (2010). Większość respondentów mających do wyboru cztery motywy wskazywała na poznanie historii obozu (63\%), pamięć o ofiarach zbrodni nazistowskich (49\%) i oddanie hołdu ofiarom obozu (45\%). Jednak aż $40 \%$ ankietowanych wskazała na ciekawość jako jeden z czterech głównych motywów odwiedzin muzeum. Pozostałe motywy, jakie wymieniali respondenci, to poszukiwania tożsamości i religia. Uzyskane rezultaty potwierdzają funkcje turystyki martyrologicznej stanowiącej podzbiór tanatoturystyki, jakimi są funkcje poznawcze, edukacyjne i religijne (fot. 22, 23).

Analizując zjawisko tanatoturystyki należy dokładnie interpretować zagadnienia związane z kulturą śmierci. Cechą współczesnego społeczeństwa jest próba zachowania ontologicznego bezpieczeństwa, co skutkuje swego rodzaju izolacją turysty od przestrzeni śmierci. Tym bardziej ciekawość i poznanie odgrywają istotną rolę $\mathrm{w}$ wymiarze profanum tanatoturystyki, a w skrajnych przypadkach również rozrywka i emocje, podobnie jak w wymiarze sacrum empatia, tożsamość, pamięć i religia.

\subsection{MORALNE DYLEMATY TANATOTURYSTYKI}

Turystyczne podróże do przestrzeni śmierci rodzą z pewnością moralne dylematy. Radykalne zmiany w strukturze społecznej i kulturze, w standardach życia i konsumpcji, w ilości i sposobach wykorzystywania czasu wolnego, $\mathrm{w}$ polityce i religijności nie pozostają bez wpływu na sferę wartości i zachowań moralnych. Moralność nie jest stała, nie jest nieczuła na zmiany 
społeczno-kulturowe. Im bardziej różnicuje się kontekst kulturowy, tym bardziej dostrzegalne są zmiany w moralności.

Zainteresowanie turystyczne przestrzeniami śmierci można rozpatrywać zarówno w kategoriach pozytywnych, jak i negatywnych. Pozytywny aspekt tanatoturystyki to kształcenie postaw patriotycznych, edukacja, wychowanie, socjalizacja, tanatopsja i wiele innych efektów kształcących postawy społeczno-religijne. Negatywne moralne kontrowersje wzbudza wykorzystanie przestrzeni śmierci do celów rozrywkowych, realizacji zainteresowań, ocenianych jako patologiczne. Podobnie postawy postmodernistyczne współczesnych turystów wielokrotnie wzbudzają moralne wątpliwości, np. odejście od tradycyjnych form turystyki, bagatelizowanie krajoznawstwa czy spłycanie postrzegania miejsc historycznych lub religijnych. Współczesny człowiek coraz częściej nie jest zainteresowany dogłębnym poznaniem i zinterpretowaniem odwiedzanej przestrzeni.

\subsubsection{TURYSTYCZNA POSTAWA WOBEC ŚMIERCI}

Ważną rolę w konstruowaniu norm moralnych odgrywa kontekst społecznokulturowy. Kontekst ten przyczynia się do pozytywnych lub negatywnych zmian $\mathrm{w}$ rozumieniu ustalonych praw. W określonym kontekście społeczno-kulturowym normy te są przyswajane lub odrzucane. Normy moralne ustalają stopień przyzwolenia na przejawianie się określonych zachowań i postaw w grupie turystów.

Zaprezentowany wcześniej model turystycznego dystansu międzypokoleniowego zdaniem autora właściwie obrazuje współczesne zachowania turystyczne i diagnozuje moralne konflikty wynikające z popkulturowego zainteresowania śmiercią. Postawy turystów zaprezentowane na rys. 36 można powiązać z postawami wobec śmierci i jej obecności w turystyce. Turysta postfiguratywny ma tradycyjny, zsakralizowany stosunek do śmierci, nie akceptuje nowoczesnych sposobów zagospodarowania i wykorzystania przestrzeni śmierci. Turysta kofiguratywny będzie miał obojętny pogląd na zmieniający się stosunek do śmierci, zwraca uwagę na edukacyjny i wychowawczy sposób interpretacji przestrzeni śmierci, która łączy pokolenia przez zrozumienie historii. Turysta prefiguratywny odrzuca tradycję, nie rozmawia o śmierci w aspekcie sacrum, traktuje śmierć jako przyczynek do popkulturowej rozrywki. Ten podział nie oznacza braku ciągłości i braku wzajemnych powiązań między poszczególnymi kategoriami pokoleniowymi. Nowoczesne podejście do śmierci może zachęcić pokolenie młodych do zainteresowania się "egzotycznym” dla niej aspektem tanatopsji, prowadzącym do zsakralizowania interpretacji śmierci w procesie edukacji. Sposób interpre- 
tacji przestrzeni śmierci determinuje ponadto sposób zagospodarowania przestrzeni historycznej, który ma swój wyraz w problematyce geografii historycznej.

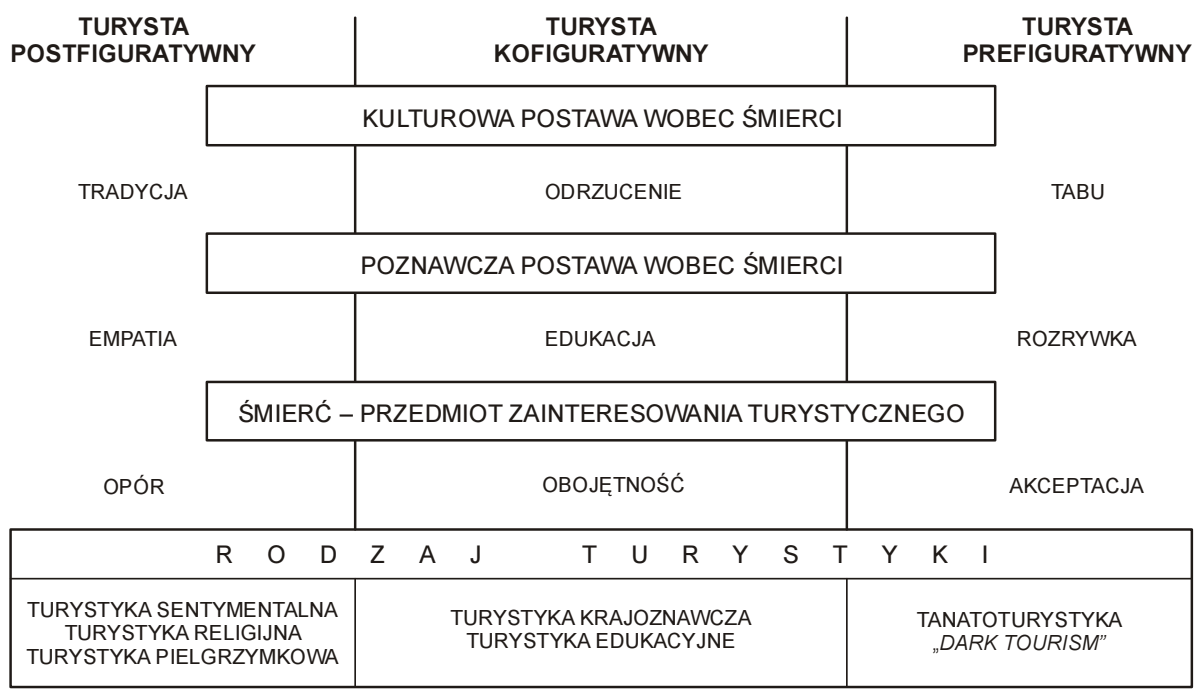

Rys. 36. Postawy turystów wobec śmierci

Źródło: opracowanie własne

Dla turystyki sentymentalnej istotna jest więź międzypokoleniowa. Jest to więź społeczna występująca między poszczególnymi generacjami. Są to powiązania pojawiające się między ludźmi, przeciwstawiające się indywidualizmowi, zorganizowane w system zdolny do trwania i rozwoju (SZCZEPAŃSKI 1970). Więź społeczna jest też równoznaczna z identyfikacją jednostki z grupą społeczną, aprobatą przynależności do grupy. W turystyce edukacyjnej istotny jest przekaz międzypokoleniowy oraz rówieśniczy. Dark tourism wprowadza śmierć w sferę profanum, emocji, co nie jest akceptowane przez starsze pokolenie, ale również nie musi być akceptowane przez pokolenie średnie, mające dobry kontakt ze starszym pokoleniem. Różnice postaw turystów wobec śmierci mogą wynikać z:

- historycznie uwarunkowanych zmian będących konsekwencją wpływów technologii i przemian społecznych;

- oddziaływania ideowego i wychowawczego dominujących grup na grupy nowatorskie;

- tendencji opozycyjnych wobec panującej kultury i systemu społecznego (negacja tradycji); 
- generacyjnych odrębności młodego pokolenia kształtującego nowe wartości społeczne, znajdujących wyraz $\mathrm{w}$ postawach i zachowaniach (ADAMSKI 1978).

Rozwój turystyki prefiguratywnej jest konsekwencją rozpadu rodziny, globalizacji i rewolucji naukowej. Ludzie będący nośnikami różnych tradycji kulturowych spotykają się w jednoczącej wszystkich teraźniejszości. W ten sposób starsze pokolenie jest swego rodzaju emigrantem, który zmuszony jest do dostosowania się do nieznanych warunków życia nowej ery (MEAD 1978, s. 115).

Dojrzałe pokolenie decyduje o tym, co jest atrakcją turystyczną, jakie produkty turystyczne tworzyć, co może wzbudzać bunt w liberalnym i wolnym pokoleniu młodych negującym sztywne ramy podróży turystycznych i narzucanych schematów turystyki. Tak rodzi się przejmowanie nawyków i fascynacja innymi kulturami. Fascynacja tym, co jest zakazane lub w ocenie starszego pokolenia nieakceptowalne lub niewykonalne. Tym samym zmianom podlega definicja atrakcyjności. To już nie jest bezpieczeństwo, wygoda, sprawdzony schemat, moda. To jest to, co nieznane, niebezpieczne, negowane - inne. W tych kategoriach atrakcyjności turystycznej odnajdziemy również rozumianą wieloaspektowo i łamiącą tabu fascynację śmiercią. Młode pokolenie "turystów-buntowników" zachowuje się jak pierwsze pokolenie, które urodziło się w nowej rzeczywistości. Dostęp do informacji, znajomość języków, nonkonformizm dostarcza bodźców do odbywania podróży do miejsc uznanych za nieturystyczne lub o ograniczonych możliwościach dotarcia. Według młodego pokolenia turystów definiowanie i rozróżnianie przedmiotów zainteresowania poznawczego $\mathrm{w}$ turystyce to anachronizm, a znajomość geografii turystycznej nie jest warunkiem odbywania świadomych podróży.

\subsubsection{MORALNY ASPEKT TANATOTURYSTYKI}

Procesy społeczne prowadzą niekiedy do zmian wartości i zachowań ludzkich, również w sferze moralnej. Społeczeństwo zachodnie jest $\mathrm{w}$ fazie przejścia od tradycji do ponowoczesności odrzucającej tradycję (MARIAŃSKI 2001). $\mathrm{W}$ turystyce $\mathrm{w}$ ostatnich kilkudziesięciu latach postępuje szybka ewolucja wynikająca z rozwoju komunikacji i globalizacji. Tym samym ponowoczesność wkroczyła już dawno do turystyki, czego wyrazem jest zainteresowanie turystyczne kulturą śmierci i cierpieniem ludzkim. Radykalne zmiany w strukturze społecznej i zawodowej, w standardach życia i konsumpcji, w ilości czasu wolnego, w kulturze, religii nie pozostają bez wpływu na sferę 
wartości i zachowań moralnych turystów. Moralność nie jest stała, podlega przemianom, często o charakterze konfliktowym wobec tradycjonalistycznych postaw starszego pokolenia. Moralność płynąca $\mathrm{z}$ wiary i religijności w Polsce traci powoli na znaczeniu w związku z sekularyzacją społeczeństwa. Proces ten określić można „kryzysem moralnym” lub „powrotem do normalności", w zależności od przyjętych poglądów na rzeczywistość.

Społeczeństwo ponowoczesne charakteryzuje się daleko idącym zróżnicowaniem poszczególnych dziedzin życia, w tym w czasie wolnym, kulturze, moralności i religijności, tworząc własne podsystemy $\mathrm{z}$ odrębnymi strukturami oczekiwań, z własnymi kodami i prawami, z własną logiką działania. Wymienione sfery życia nie tworzą już jedności. To co zakazane jest $\mathrm{w}$ jednej, dopuszczone może być w innej. Tradycyjne postawy wobec określonych działań są zmienione lub odwrócone. Na przykład seksturystyka wykorzystująca patologiczną i etycznie naganną potrzebę konsumpcji seksu z nieletnimi jest ze względów moralnych nieakceptowana $\mathrm{w}$ wielu społecznościach, w tym stanowiących zaplecze konsumpcyjne, przy jednoczesnej „cichej” akceptacji podmiotów organizujących i obsługujących tego typu podróże. Tanatoturystyka i mroczna turystyka wykorzystuje m.in. zapotrzebowanie na makabrę i kontakt ze śmiercią, co również wzbudza kontrowersje i moralny opór.

Moralność jest swoistym produktem komunikacji społecznej wynikającej $\mathrm{z}$ indywidualnych decyzji jednostek i międzyludzkiego współżycia. Jej najważniejszy składnik stanowią wartości moralne będące odzwierciedleniem tego, co w społeczeństwie jest uznawane za dobre lub złe, właściwe lub niewłaściwe, szlachetne lub nieszlachetne (MARIAŃSKI 2001, s. 19). Tak rozumiane wartości odzwierciedlają świadomość zbiorową, a nie obiektywne czy prawdziwe wartości (GRZEGORCZYK 1989). Wartości moralne ulegają zmianie w nowoczesnych społeczeństwach, szczególnie w społeczeństwach prefiguratywnych. J. MARIAŃSKI (2001, s. 27) proponuje cztery modele przemian wartości i norm moralnych, które w opinii autora bardzo dobrze opisują również przemiany w postawach społecznych wobec śmierci. Jest to:

- sekularyzacja moralności (interpretacji śmierci) - rozumiana jako odchodzenie od modelu moralności religijnej, określanego często jako kryzys moralny; nawiązywał do tego JAN PAWE€ II (1995) w Evangelium Vitae;

- indywidualizacja moralności (subiektywny sposób traktowania śmierci we współczesnym świecie) - wiązana z postmodernistycznym rozpadem wartości $\mathrm{w}$ kulturach prefiguratywnych, promocją wolności i autonomii jednostki; 
- przemiana wartości (tabu śmierci, pornografia śmierci) - rozpad dawnych wartości i tworzenie nowych dopasowanych do społeczeństwa pluralistycznego;

- reorientacja wartości moralnych $\mathrm{w}$ duchu religijności - sprzeciw wobec eutanazji, aborcji, popularyzacji kultury (cywilizacji) śmierci, niekiedy o charakterze fundamentalistycznym, lub ożywienie moralne bez zabarwienia religijnego.

Tanatoturystyka czy mroczna turystyka jest konsekwencją w pewnym sensie nowej fazy rozwoju społeczeństwa świata rozwiniętego, zwanej ponowoczesnością (postmodernizmem). Turysta ponowoczesny odkrywa świat na nowo, dysponując nowymi środkami informacji, komunikacji czy transportu. Globalizacja świata prowadzi do zachwiania tradycyjnych postaw moralnych, również w sferze turystyki. W społeczeństwach radykalnie nowoczesnych lub ponowoczesnych turystyka, tak jak inne sektory życia, są kierowane przez niespójne, czasem sprzeczne wartości i systemy znaczeń. Zinstytucjonalizowane wartości i normy, przekazywane $\mathrm{w}$ tradycji tracą w warunkach zmienności i ruchu swoją oczywistość kulturową. Śmierć, umarły, pogrzeb, cierpienie zyskały zupełnie nowy wymiar w młodym pokoleniu w stosunku do minionego czasu. Jest to wymiar wirtualny, nierzeczywisty, niedotyczący jednostki: „śmierć dotyka innych, nie mnie”. Dlatego rosnąca popularność mrocznej turystyki wymusza organizację nowych atrakcji turystycznych, moralnie nieakceptowanych, szczególnie przez starsze pokolenia. Poszerzanie się rynku mrocznej turystyki i tanatoturystyki rodzi moralny opór, szczególnie lansowaną przez media oceniające ten rodzaj turystyki jako patologia (SEATON, LENNON 2004, STONE, SHARPLEY 2008). Moralność rozumiana $\mathrm{w}$ aspekcie religijnym nie pozwala na wykorzystywanie śmierci dla sfery profanum życia. Z tej perspektywy moralne aspekty tanatoturystyki nawiązują do prac nad moralnością i religijnością Durkheima (OsSOWSKA 1969).

Zmniejszenie znaczenia religii $\mathrm{w}$ życiu społecznym prowadzi do sekularyzacji moralności, jest odchodzeniem od dotychczasowych, religijnie uzasadnionych wartości morlanych. Sekularyzacja oddziałuje destrukcyjnie na tradycyjne treści. $\mathrm{W}$ warunkach globalizacji i liberalizmu kulturowego religijne spojrzenie na śmierć zastępowane jest spojrzeniem pragmatycznym. Rozwój usług funeralnych i medykalizacja śmierci konsekwentnie doprowadza do odrzucenia obrzędowości w sferze publicznej, a co za tym idzie oddalania się jednostki od tradycyjnego szacunku do śmierci. Wyraźnym dowodem na odrzucenie religijności śmierci jest jej powszechność w mass mediach i kulturze wizualnej, co doprowadziło do obnażenia śmierci z sacrum i patologicznej interpretacji kultury śmierci. Tanatoturystyka, jak wcześniej 
wspominał autor, odgrywa rolę również $\mathrm{w}$ kreowaniu pożądanych postaw religijnych wobec śmierci.

Rzeczywiście, przy badaniu z perspektywy Durkheima, moralna panika wobec mrocznej turystyki prowokuje zarówno w aspekcie produkcji atrakcji, jak i ich konsumpcji, postrzeganej na poziomie jednostki jako nieetyczna. Należy jednak pamiętać, że poznanie przez turystę aspektów związanych z historią śmierci na poziomie zbiorowym ma głębokie znaczenie dla społeczeństwa, również w kategoriach próby ustanowienia lub utrwalenia określonych norm moralnych, norm postępowania wobec śmiertelności człowieka. Innymi słowy, moralna dyskusja nad wykorzystaniem przestrzeni śmierci $\mathrm{w}$ turystyce jest konsekwencją procesu interpretacji i dyskusji generowanych przez mroczną turystykę i tanatoturystykę.

W warunkach wzrastającej pluralizacji i indywidualizacji zachowań turystycznych kształtują się postawy charakterystyczne dla społeczeństwa doznań. Nieograniczony rynek podaży turystycznej (produktów i usług) sprawia, że turyści poszukują wciąż nowych ofert i propozycji, wśród których można dowolnie wybierać (rys. 37). Wraz z poszukiwaniem nowych doznań nasila się estetyzacja produktu turystycznego. Przedmioty będące w kręgu doznań turystycznych muszą mieć wartość estetyczną.

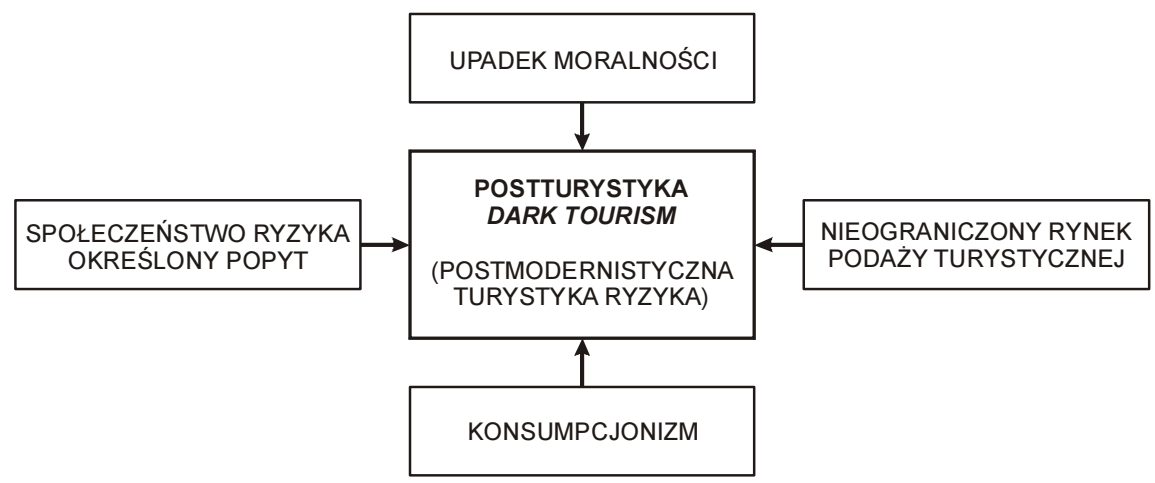

Rys. 37. Czynniki kształtujące modę na mroczną turystykę (dark tourism) Źródło: opracowanie własne

Jednym $\mathrm{z}$ istotnych elementów kultury jest religia. W tradycyjnych społeczeństwach ludzie akceptowali to, co prawo religijne nakazywało. Szczególnie sposoby postępowania ze zmarłym wynikały z narzuconych norm. $\mathrm{W}$ warunkach modernizacji społeczeństwa nastąpiło oddzielenie sfery sakralnej od świeckiej, religijności od moralności. Turystyka zyskała niezależność od religii. Należy pamiętać, że turystyka, której początki są upatrywane 
w religijnych pielgrzymkach, również współcześnie jest podporządkowana pewnym normom religijnym, czego potwierdzeniem są zasady zwiedzania obiektów sakralnych.

Odejście od norm religijnych sprzyja zmianie funkcji przestrzeni śmierci na rzecz funkcji poznawczych, rekreacyjnych czy rozrywkowych nieakceptowanych przez instytucje religijne. Turystyczne wykorzystanie przestrzeni śmierci nie może być jednak oceniane jedynie w kategoriach pejoratywnych. Wielokrotnie w książce autor zwracał uwagę na pozytywne aspekty odwiedzania przestrzeni śmierci. Tanatoturystyka ma również wartości prospołeczne, a więc "system takich wartości, który stanowi uzasadnienie moralnej słuszności czynów mających na względzie dobro innych ludzi, realizowane w mniejszym lub większym stopniu kosztem dobra działającej jednostki" (KICIŃSKI, KURCZEWSKI 1977, s. 72).

Zrozumienie i uszanowanie żałoby, pamięci o umarlych, obrzędów i rytuałów, łagodzących żal wynikający ze śmierci bliskich, jest takim właśnie działaniem. Dlatego poznawanie zwyczajów poprzez podróże i odwiedzanie miejsc związanych ze śmiercią można określić jako działalność edukacyjną, wychowawczą i prospołeczną.

W turystyce obserwowana jest indywidualizacja zachowań, polegająca na niezależności wobec systemów społecznych, która jest częścią życia skoncentrowanego na doznaniach, przyjemnościach, zaspokajaniu własnych potrzeb, krytycyzmie wobec autorytetów. W tych ramach indywidualizacja wartości moralnych powoduje własny, subiektywny sposób oceny postępowania, mogący odbiegać od ogólnych norm. Turystyczne poznanie stref śmierci i obszarów niebezpiecznych stoi w opozycji do przyjemnościowego charakteru podróży turystycznych. Społeczeństwo ryzyka wymaga kontaktu z ryzykiem i geograficzną odmiennością kulturową. $W$ tradycyjnym ujęciu turystyki nie mieści się np. wycieczka do Palestyny, Egiptu, Tunezji w celu bliskiego kontaktu $\mathrm{z}$ atmosferą zamieszek politycznych czy podróż na obszary zagrożone wojną, takie jak Afganistan, Irak czy Syria, albo spotkanie $\mathrm{z}$ agresywnie nastawionymi do intruzów tubylcami. Spotkania ze strefą śmierci odbywają się jednak wielokrotnie pod kontrolą organizatora turystycznego, dając turyście możliwość niecodziennych przeżyć, jednak mało autentycznych, chwilowych i stojących w sprzeczności z etyką zawodową.

Walory kulturowe podlegają jak każdy walor ocenie turysty. Ocenę walorów można rozumieć jako emocjonalny lub racjonalny mechanizm ich selekcji, konsekwencją czego jest dystans wobec nich, ich akceptacja lub odrzucenie. Ocena walorów kulturowych, w tym wytworów kultury śmierci, podlega modyfikacji wynikającej z wpływu czynników zewnętrznych (np. 
przekonania autorytetów, publiczna manifestacja poglądów określonych grup, ocena innych).

W 2010 roku, po katastrofie samolotu prezydenckiego w Smoleńsku, na pokładzie którego zginęło 96 osób, media kreowały negatywny obraz biur turystycznych organizujących wyjazdy na miejsce katastrofy. Ocena tych wyjazdów, traktowanych jako sposób na komercjalizację przestrzeni śmierci i pamięci o narodowej tragedii, była manipulowana przez polityków i dziennikarzy mających swobodny dostęp do mass mediów. Wyjazdy na miejsca tragedii są jednak powszechną praktyką oddania hołdu zmarlym oraz upamiętnienia ich śmierci i mają często charakter pielgrzymki rodzinnej, lokalnej, narodowej czy religijnej. Również tego typu podróże są zróżnicowane pod względem motywu jej odbycia.

Jedną z istotnych koncepcji oceny wytworów kulturowych, bardzo przydatnych $\mathrm{w}$ analizie tanatoturystyki, jest etnocentryzm i relatywizm kulturowy.

Etnocentryzm jest zespołem przekonań, na mocy których własna grupa jest uznawana za centrum wszystkiego oraz za miarę i skalę dla innych grup i zjawisk społecznych (GOLKA 2008, s. 213). Wyrasta z przekonania o wyższości własnej grupy i jej kultury nad innymi, traktowanymi jako gorsze. W turystyce spotykamy często postawy etnocentryczne zarówno wśród osób obsługujących wyjazd (np. przewodników), jak i samych turystów wchodzących w konflikt ze społecznościami lokalnymi. Etnocentryzm może objawiać się afirmacją postaw wobec własnej kultury lub hegemonią własnych wartości i nietolerancją wobec innych. W opozycji do etnocentryzmu stoi relatywizm kulturowy, zakładający równość nieporównywalnych kultur i obiektywizm w ich opisie.

Turystyka kulturowa winna prowadzić do przeciwstawiania się etnocentrycznemu przekonaniu o wyższości własnej kultury względem innych. Etnocentryzm prowadzi bowiem do stosowania reguł i wartości własnej kultury w ocenie zachowań i wartości innej kultury, podczas gdy relatywizm kulturowy nie dopuszcza oceny jednej kultury według standardów drugiej. Jednak trudno przyjmować pogląd, że skoro reguły obyczajowe i moralne są po części różne w kulturach, to wszystkie $\mathrm{z}$ nich należy uznawać. Rodzi się zatem pytanie, czy np. kanibalizm, mord i okaleczanie rytualne należałoby, wobec stosowania zasady relatywizmu kulturowego, uznać za uzasadnione i usankcjonować z perspektywy dziedzictwa cywilizacji Zachodu?

$\mathrm{W}$ turystyce widoczna jest masowa produkcja kopii, podobnie jak w pozostałych sferach działalności i zachowań społecznych. Dzieło (produkt) rodzi się w odtwarzalnej formie jako potencjalnie "nieograniczony nakład" kopii, pojawiające się masowo produkty wzbudzające kontrowersje i wywo- 
łujące moralną panikę. Do takich produktów i atrakcji należą produkty wykorzystywane $\mathrm{w}$ mrocznej turystyce i tanatoturystyce. Przyczyną takiego stanu rzeczy jest m.in. eksponowanie lub ukrywanie etycznych nakazów. Nakaz pobudza i potajemnie ukierunkowuje ekspresję życia. O ile ekspresja ta zachowuje swoją bezpośredniość, to obiekty ją wywołujące i przyciągające opuścily przestrzeń bliskości. Ekspresja śmierci występuje w pewnym oddaleniu od turysty. Oprócz tego, co może zobaczyć w najbliższej okolicy, potencjalny turysta otrzymuje pośrednią wiedzę o odległym cierpieniu i okrucieństwie za pomocą środków masowego przekazu. Z. BAUMAN (1998) zwraca uwagę na pośredniość zetknięcia się z ludzkim cierpieniem, co wzbudza abstrakcyjność moralnego wyboru: oglądać - nie oglądać. Ubocznym produktem komunikacyjno-informacyjnej eksterytorialności uprzywilejowanych grup społecznych są miejsca odcięte od źródeł informacji, pozostawione własnemu losowi. Wpływa to na rosnąca polaryzację społeczeństwa, czego konsekwencją jest również zainteresowanie społecznych elit obszarami uważanymi za odrażające i „niebezpieczne”, a to już prowadzi do mrocznej turystyki. Turysta z bezpiecznej, domowej perspektywy otrzymuje produkt pośredni $\mathrm{w}$ formie przekazu medialnego, który wpływa na wzbudzenie zainteresowania miejscem cierpienia. Mechanizm ten wywołuje potrzebę podróży do nieznanych bliżej przestrzeni niebezpiecznych. Dostęp do tych przestrzeni, podobnie jak informacja $\mathrm{z}$ nich płynąca, jest raczej nieograniczony. Zasada ta nie działa $\mathrm{w}$ przeciwnym kierunku. Mieszkańcy przestrzeni niebezpiecznych mogą mieć ograniczony dostęp do informacji z przestrzeni bezpiecznych, tak jak ograniczone możliwości podróży do nich (rys. 38).

Ci, którzy żyją w rozwiniętym „pierwszym świecie”, bez granic (przestrzeń warstw wyższych, globalnych turystów), gdy tylko zapragną mogą znaleźć się (duchowo, jak i cieleśnie) bez większych przeszkód w „drugim świecie" (przestrzeń warstw niższych, lokalnych społeczeństw), mającym ustalone geograficzne granice tożsamości. Mieszkańcy "drugiego świata" mogą znaleźć się w "pierwszym świecie” - ze względu na istniejące ograniczenia - zazwyczaj tylko duchowo (np. dzięki telewizji i Internetowi). Brak jest jednak ciągłości zainteresowania turystów "pierwszego świata” "drugim światem", z którego otrzymują praktycznie nieograniczone informacje. W odniesieniu do tanatoturystyki jest to prawidłowość występująca na różnych poziomach systemów społecznych. Może to być poziom turysta-społeczność archaiczna (tradycyjna), turystysta-społeczność zamknięta (izolowana). Informacja w systemie komunikacji dociera nieograniczenie $\mathrm{z}$ kierun$\mathrm{ku}$ producenta atrakcji turystycznych, ale ograniczoność informacji może wystąpić z kierunku konsumenta tych atrakcji (turysty), co prowadzić może do wzajemnie błędnej interpretacji wytworów kultury. 


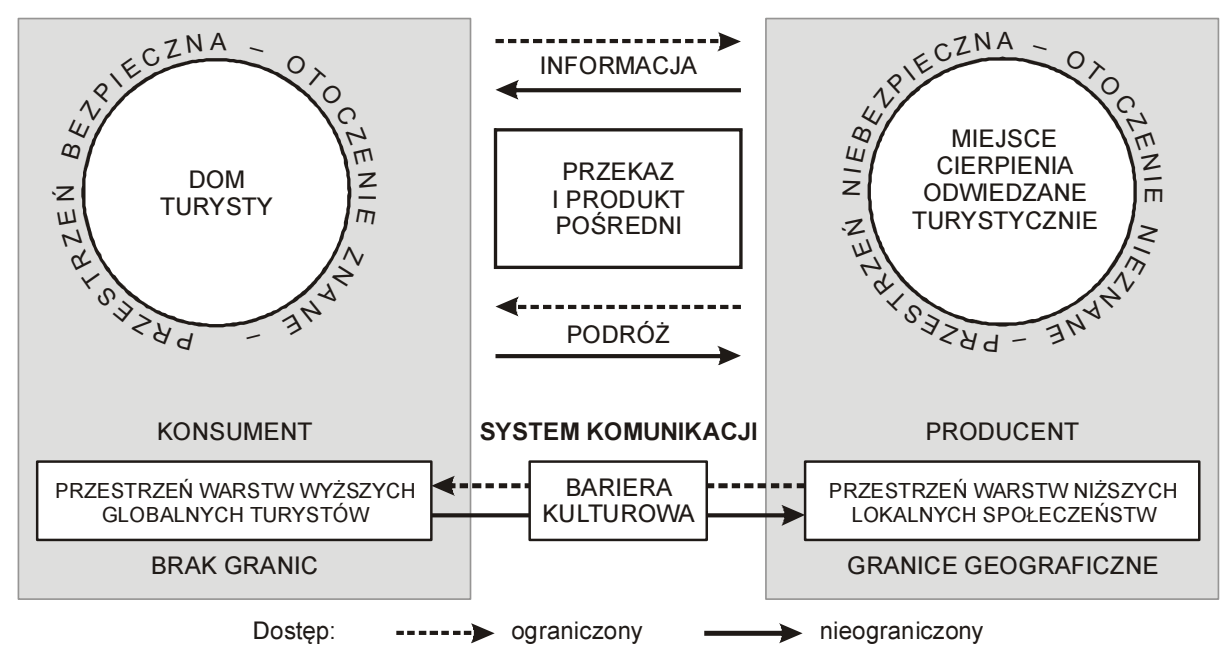

Rys. 38. Relacje między przestrzenią bezpieczną a niebezpieczną Źródło: opracowanie własne

Świat "produkujący” cierpienie i okrucieństwo generuje również biernych obserwatorów, doświadczających cierpienia innych za pośrednictwem szklanego ekranu. Obrazów docierających do odbiorcy jest bardzo dużo, tylko jak długo te obrazy tkwią w umysłach ludzkich i w jakim stopniu wyzwalają chęć kontaktu z bardziej urealnionym cierpieniem poprzez podróż turystyczną (TESTER 1997)?

Oglądanie obrazów śmierci i okrucieństwa stało się nową "tradycją" naszej epoki rządzonej przez media. Obrazy utraciły znaczną zdolność wstrząsania, nastąpiło znużenienie współczuciem (BAUMAN 2006b). W zależności od tego co oglądamy, przyswajanie obrazów może przeszkodzić, a nie ułatwić przyswajanie wiedzy. Może udaremnić proces rozumienia zjawiska lub poszukiwania jego przyczyn. Potwierdzeniem postawionej tezy są przekazy telewizyjne, które media kreują na widowiska wzmagające codzienną moralną obojętność wobec śmierci. Rozwinięta część świata otacza się kordonem nieangażowania. Informacje spoza owego kordonu to m.in. informacje o wojnach, zbrodniach, głodzie, cierpieniu, katastrofach - czyli zagrożeniach (BAUMAN 2000a). Obrazy te kreują wirtualne zainteresowanie śmiercią, którą chcemy poznać w bezpieczny sposób, czemu służą również obiekty muzealne i rozrywkowe lub podróże do miejsc już "ustabilizowanych", a mających w pamięci niedawne akty zbrodni, cierpienia i śmierci (turystyka wojenna, phenix tourism).

Obrazy barbarzyństwa panującego w krajach, gdzie żyją potencjalni imigranci podbudowują ego "turystów globalnych", dla którego poparcia brak 
jest argumentów natury racjonalnej i moralnej. Cierpiąca "ludność lokalna” jest utrzymywana w ryzach lokalności, pozwalając "turystom globalnym" podróżować bezpiecznie.

Turysta wielokrotnie płaci za prawo do ignorowania tubylczych uczuć i trosk, do otaczania się własną siecią znaczeń. To co dla tubylcy jest codzienną rutyną, dla turysty jest zbiorem egzotycznych ciekawostek i okazją do przeżywania emocji (BAUMAN 1996). Odpowiedzialność moralna turysty obciąża i psuje wizerunek wakacyjnej radości życia. Dlatego tak istotna jest powierzchowność poznania waloru, bez zagłębiania się w jego sens. Kraje turystyczne postrzegane są jako „wyspy szczęścia”, niestety, często lokalne społeczności cierpią i umierają, dotknięte są konflikatami i katastrofami. Śmierć i cierpienie są w takich sytuacjach pobieżnie, obrazowo, doznaniowo i emocjonalnie poznawane, bez efektu etycznej i moralnej nauki, z możliwością zmiany odwiedzanej rzeczywistości na lepszą. Z. BAUMAN (1996) wykazuje, że idealnym stanem dla turysty jest być turystą zawsze i wszędzie, nie należeć do miejsca, wobec którego utrzymuje się dystans duchowy, wbrew fizycznej bliskości. Zachowywać się z rezerwą, być wolnym i zaaplikować sumieniu moralnemu na czas podróży „proszki nasenne”.

Bezpieczeństwo turysty doświadczajacego zewnętrznej rzeczywistości, w jednoczesnym oderwaniu kulturowym od niej, określa się mianem „bańki środowiskowej" (BOORSTIN 1961), z której znakomita większość biur turystycznych korzysta, oferujac w ramach luksusowych pobytów turystycznych wycieczki fakultatywne, np. do faweli Rio de Janeiro, osad plemion afrykańskich czy innych obszarów skrajnego ubóstwa i ludzkiego cierpienia, również do miejsc nacechowanych zagrożeniem życia i śmiercią.

\subsubsection{ZNACZENIE TRAUMY W TANATOTURYSTYCE}

Śmierć jednoznacznie kojarzy się z negatywnymi przeżyciami, które mogą być powiązane $\mathrm{z}$ traumą. Trauma kulturowa ma miejsce wówczas, gdy członkowie zbiorowości czują, że zostali poddani straszliwemu wydarzeniu, pozostawiającemu nieusuwalne ślady na ich grupowej świadomości, na zawsze naznaczającemu ich wspomnienia, zmieniającemu ich przyszłą tożsamość nieodwołalnie. Są to znaczeniowe i przyczynowe związki pomiędzy poprzednio niepowiązanymi wydarzeniami, strukturami, spostrzeżeniami i działaniami (AlEXANDER 2010, s. 195). Poprzez konstrukcję traumy kulturowej grupy społeczne nie tylko rozpoznają istnienie oraz źródło ludzkiego cierpienia, ale przyjmują na siebie określoną dozę odpowiedzialności za nie. Budują więzi solidarności z cierpiącymi, podzielając $\mathrm{w}$ ten sposób cierpienie innych. Socjologowie podkreślają wagę znalezienia pewnych zbiorowych 
środków, służących cofnięciu represji i dopuszczeniu do wyrażania tłamszonych emocji straty i żałoby poprzez publiczne akty upamiętnienia wydarzenia lub człowieka. Sposobem na zaleczenie traumy jest pielgrzymka lub podróż turystyczna odbywana do miejsc związanych z cierpieniem i śmiercią $w$ celu upamiętnienia ofiar oraz podtrzymania pamięci o traumatycznych wydarzeniach poprzez proces edukacji (rys. 39).

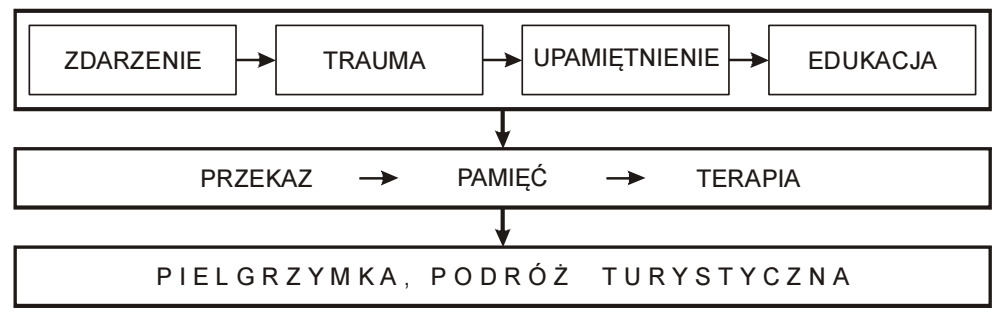

Rys. 39. Znaczenie traumy dla motywu podróży Źródło: opracowanie własne

Wysiłki upamiętnienia ofiar służą przywróceniu obiektywnej rzeczywistości brutalnych wydarzeń, oddzieleniu od nieświadomych wypaczeń pamięci. Przykładem mogą być pomniki, mauzolea i muzea upamiętniające ludobójstwa i zbiorowe mordy na tle etnicznym, religijnym lub politycznym, w tym m.in. Holokaust. Obiekty te są odpowiedzią na zbiorową traumę społeczeństw dotkniętych tragedią, są również sposobem upamiętnienia i edukacji, których odbiorcami są m.in. turyści i pielgrzymi.

Zjawiskom przypisuje się status traumy nie tylko z powodu jej faktycznej szkodliwości, ale również dlatego, że jest to zjawisko gwałtownie i ze szkodą oddziałujące na tożsamość zbiorową pokrzywdzonej grupy. Pamięć i znaczenie wydarzeń pozostaje pod wpływem struktur władzy oraz zdolności do refleksji grup społecznych (rys. 40).

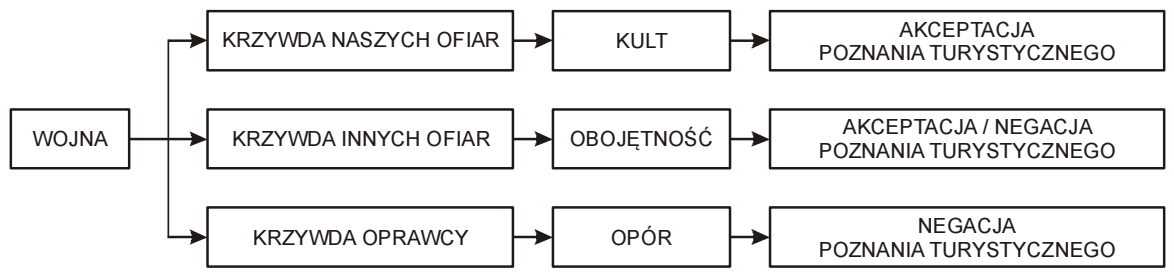

Rys. 40. Turystyczna interpretacja traumy Źródło: opracowanie własne 
Akceptujemy pomniki i cmentarze żołnierzy polskich, obojętnie lub niechętnie traktujemy sojuszników i ofiary niebędące Polakami, negujemy pamięć o przeciwnikach lub agresorach. Na obszarze Polski przykładami obiektów zarówno akceptacji, jak i negacji poznania turystycznego są np. pomniki pomordowanych w okresie II wojny światowej Żydów i Ukraińców, natomiast negacji poznania turystycznego przez część społeczeństwa podlegają głównie pomniki i cmentarze żołnierzy Wermachtu i Armii Czerwonej. Wynika $\mathrm{z}$ tego, iż istotnym czynnikiem interpretacji traumy jest charakter wydarzenia, charakter grupy roszczeniowej i transmitera (grup społecznych dokonujących przekazu). Efektem traumy jest zazwyczaj symboliczne przedstawienie i przekaz, który może mieć formę pomnika, muzeum, inscenizacji, wycieczki, tym samym atrakcji lub produktu turystycznego.

Lukę między wydarzeniem a przedstawieniem można postrzegać jako "proces traumy". W procesie transmisji tworzone są przedstawienia wydarzeń przeszłych, teraźniejszych i przyszłych, które mogą być postrzegane jako roszczenie co do kształtu rzeczywistości społecznej, jego przyczyn i odpowiedzialności za działania, jakie implikują (ALEXANDER 2010, s. 205). Roszczenia te mogą być wyrażane wobec profanacji określonych wartości sacrum, wywołując jednocześnie żądania emocjonalnego i symbolicznego odszkodowania. W ten sposób powstają np. obiekty martyrologiczne, które mają już u podstaw stanowić cel podróży turystycznych, podczas których ma następować upowszechnienie wiedzy o miejscu, wydarzeniu i ofiarach (ZIĘBINSKA-WITEK 2005, 2012). Na podstawie badań J.C. AlEXANDRA (2010, s. 207) można sklasyfikować przekaz mający miejsce w obiektach upamiętniających traumę, który dotyczy:

a) charakteru cierpienia - co faktycznie stało się określonej grupie?;

b) charakteru ofiary - jaką grupę osób dotknęło cierpienie (charakter i specyfika jednostki, zbiorowości?);

c) relacji między ofiarami traumy a szerszą publicznością - w jaki sposób publiczność utożsamia się z ofiarami lub wydarzeniem?;

d) przypisania odpowiedzialności - ustalenie tożsamości sprawcy (rys. 41). Zazwyczaj na początku przekazu traumy publiczność dostrzega niewielki bądź żaden związek z represjonowaną grupą. Dopiero gdy ofiary są przedstawione $\mathrm{w}$ kategoriach cenionych cech, podzielanych i utożsamianych przez publiczność, będzie ona $\mathrm{w}$ stanie uczestniczyć symbolicznie $\mathrm{w}$ doświadczeniu traumy. Wskazują na to badania prowadzone w Państwowym Muzeum Auschwitz-Birkenau (BERBEKA, red. 2012). Czy los Cyganów i ich trauma dotyka w taki sam sposób Polaków, jak ich samych? Kto był sprawcą Holokaustu - Niemcy czy naziści? 


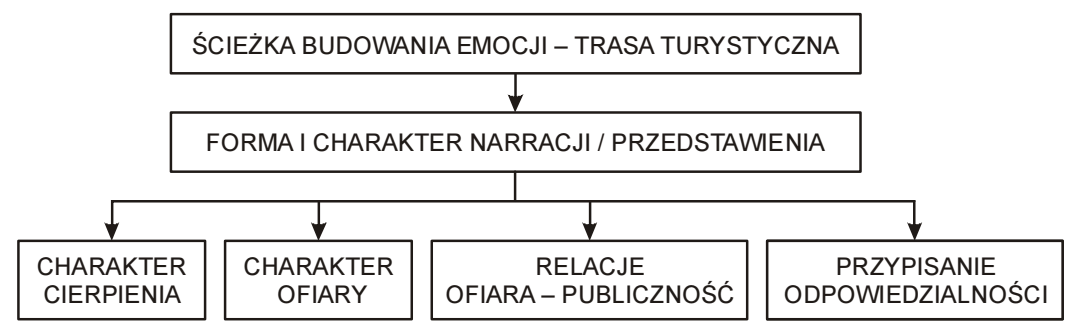

Rys. 41. Ścieżka przekazu w miejscach dokumentujących śmierć i cierpienie Źródło: opracowanie własne na podstawie J.C. ALEKSANDRA (2010, s. 207)

Pamięć i turystyka poznawcza mogą sprzyjać rozwojowi procesu traumy poprzez upowszechnianie roszczeń do traumy. Sprzyjają temu zgromadzone zasoby, wystąpienia autorytetów, kompetencja interpretacyjna uzależniona od wiedzy. Obiekty odwiedzane przez turystów tworzą narrację i przekaz publiczny o traumie. Rozpoznawalni stają się sprawcy zbiorowych cierpien, zmuszani do przyjmowania odpowiedzialności moralnej. Rosną więzi solidarności społecznej i tożsamości. Proces traumy pozwala zdefiniować zbiorowościom nowe formy odpowiedzialności moralnej i modyfikować politykę historyczną.

Forma przedstawienia śmierci i sposób narracji faktu historycznego są bardzo ważne dla interpretacji zdarzenia i odwiedzanego miejsca. Autentyczność przekazu o śmierci i jego odbiór, następujący w wyniku recepcji bodźców zewnętrznych, mają istotne znaczenie $\mathrm{w}$ zrozumieniu przyczyn i skutków określonej śmierci (STONE 2012). W przestrzeniach śmierci odwiedzanych poznawczo śmierć jest przedstawiana $\mathrm{w}$ taki sposób, aby poprzez doświadczenia turysty została przez niego w określony sposób „skonsumowana". Poprzez zapewnienie odpowiedniej narracji i jej oprawy organizator "przestrzeni pamięci o śmierci" może zrealizować wcześniej postawione cele. $W$ zależności od tego, czy cele są edukacyjne czy rozrywkowe, forma przekazu będzie odmienna, choć za każdym razem może być nastawiona na wywołanie określonych reakcji odbiorcy, często drastycznych - szoku, odrazy, strachu, smutku itp. W obiektach dokumentujących terror i ludobójstwo istotny jest przekaz edukacyjny $\mathrm{w}$ postaci obrazowego uświadomienia odbiorcy, w jakich warunkach, na jakich zasadach odbywała się zbrodnia. Celem tego przekazu jest nauka historii, zachowanie zdarzenia w pamięci, ale jednocześnie kształcenie określonych postaw społecznych. Oczywiście dyskusyjne jest stawianie tezy wskazującej na rozrywkowy charakter motywów odwiedzania opisywanych miejsc. Jednak wiele tego typu wizyt odbywa się w trakcie dłuższych pobytów wypoczynkowych lub podróży turystycznych, a odwiedzane miejsca pamięci-muzea traktowane są jako kolejne atrakcje 
turystyczne lub składowe większych produktów turystycznych. Pomijając aspekt etyczny obiekty takie, jak Państwowe Muzeum Auschwitz-Birkenau w Oświęcimiu, Strefa Zero, Toul Sleng, odwiedzane są również jako miejsca "mrocznej rozrywki" (STONE 2009a).

\subsection{TYPOLOGIA TANATOTURYSTYKI}

Na podstawie przedstawionych wcześniej analiz teoretycznych podróży turystycznych do przestrzeni śmierci autor ponownie definiuje tanatoturystykę:

Tanatoturystyka to specyficzny rodzaj turystyki kulturowej obejmującej podróże do przestrzeni śmierci $\mathrm{w}$ celach poznawczych, edukacyjnych, pielgrzymkowych i rozrywkowych, gdzie przedmiotem zainteresowania turysty jest kultura śmierci ${ }^{9}$.

Tanatoturystykę należy rozpatrywać z punktu widzenia:

- kresu życia (człowieka, zwierzęcia, rośliny, przestrzeni);

- interpretacji przestrzeni śmierci i kultury śmierci;

- motywów podróży;

- skutków podróży.

W kontekście ruchu turystycznego tanatoturystyka jest uwarunkowana charakterem środowiska emitującego i recepcyjnego, przede wszystkim w wymiarze społeczno-kulturowym (zachowania społeczne, światopogląd), historycznym (dziedzictwo i jego interpretacja), psychologicznym (motywy, potrzeby i celowość), ekonomicznym (produkt turystyczny) oraz geograficznym (zróżnicowanie przestrzenne i krajobraz).

Turystyka kulturowa stwarza możliwości lepszego poznania i zrozumienia wartości reprezentowanych przez wytwory kultury, w tym kultury śmierci. Miejsca upamiętniające śmierć lub tragedię ludzką turysta może odbierać jako interesujące, szokujące lub ważne. Mogą stanowić dla niego również wyłącznie popularną „,atrakcję turystyczną". Nawiązanie do badań K. PRZECŁAWSKIEGO $(1987,1996)$ jest bardzo ważne dla zrozumienia motywów i zachowań turystów odwiedzających przestrzenie śmierci, gdzie istotna jest interpretacja miejsca lub zdarzenia, szacunek do śmierci i zmarłych oraz zrozumienie ludzkiego cierpienia. Owa interpretacja wspomagana jest często przez materiały informacyjne, opis eksponatów, pracę przewodników. Potrzebę symbolicznego „kontaktu” ze śmiercią i przemocą w ramach tanatoturystyki M. FOLEY i J. LENNON (1997) tłumaczą chęcią doświadczenia

\footnotetext{
${ }^{9}$ Przestrzeń i kultura śmierci zostały zdefiniowane wcześniej. Definicja tanatoturystyki jest zmieniona i uproszczona w stosunku do wcześniejszych propozycji autora (TANAŚ 2006a, 2008b).
} 
odmiennej skrajności, w przeciwieństwie do monotonnego, codziennego życia i podróży, pragnienia spotkania czegoś nowego, odmiennego, stojącego w opozycji do konwencjonalnej i tradycyjnej (postfiguratywnej) turystyki.

Turystyka jest klasyfikowana w bardzo zróżnicowany sposób, w zależności od przyjętego kryterium (WARSZYŃSKA, JACKOWSKI 1978, KUREK, red. 2008, GAWORECKI 2006, KOWALCZYK 2000). Na potrzeby klasyfikacji tanatoturystyki autor posłuży się kryterium przedmiotowym, do którego zalicza motyw, cel podróży i przedmiot zainteresowania turystycznego. Motywem podróży tanatoturystycznej - jak już wcześniej wspominano - będzie przede wszystkim poznanie, edukacja, religia, rekreacja.

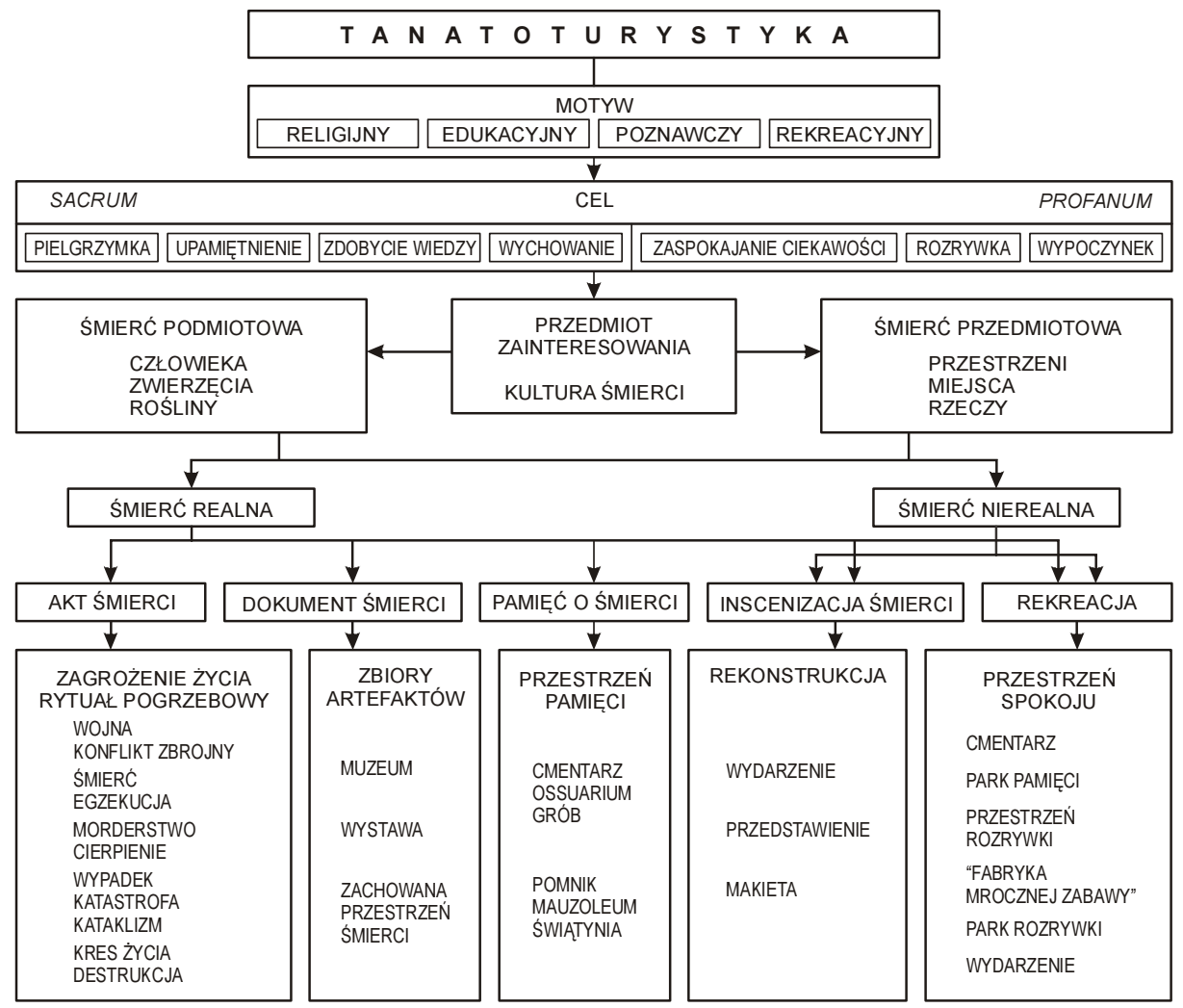

Rys. 42. Istota podróży tanatoturystycznych (motywy, cele, przedmiot zainteresowania) Źródło: opracowanie własne

Celem podróży może być upamiętnienie, pielgrzymowanie, wychowanie, zdobycie wiedzy i zaspokojenie ciekawości. W ograniczonym stopniu tanatoturystykę określa motyw rekreacyjny, a celem jest rozrywka i wypo- 
czynek. Uwzględniając przedmiot zainteresowania turystycznego można powiedzieć, że tanatoturystykę cechują śmierć podmiotowa (człowieka, zwierzęcia, rośliny) i przedmiotowa (obiektu, miejsca, przestrzeni), a w konsekwencji kultura śmierci i jej wytwory (rys. 42).

Tanatoturystyka obejmuje podróże nacechowane:

1. Aktem śmierci - miejsca, w których turysta:

- jest poddany realnemu zagrożeniu życia (bezpośrednia obserwacja działań wojennych, niebezpiecznych wydarzeń, takich jak potyczki zbrojne, kataklizmy, wypadki, katastrofy, zachowania społeczne);

- jest przygotowanym i świadomym świadkiem realnej śmierci (egzekucji, tortury, morderstwa, gwałtownej lub powolnej śmierci związanej z rytuałem odejścia, pogrzebu);

- jest świadkiem niespodziewanej śmierci (wypadek, katastrofa, kataklizm, atak terrorystyczny);

- jest świadkiem innego kresu życia, destrukcji (rytualnego uboju, niszczenia przestrzeni ożywionej i nieożywionej).

Jest to skrajnie „mroczna” kategoria tanatoturystyki, szczególnie jeżeli dotyczy ludzkiego życia. Współcześnie incydentalna i uznawana za niedopuszczalnie patologiczne zachowanie. Kategoria podróży niemieszcząca się w powszechnych klasyfikacjach podróży turystycznych, choć obserwowanych i badanych, a historycznie udokumentowanych.

2. Dokumentacją śmierci - miejsca, w których turysta spotyka się z artefaktami dokumentującymi śmierć, jej przyczyny i skutki, akt, rytuał, tradycje; do grupy tej zaliczamy zbiory w postaci dowodów zbrodni, narzędzi tortur, szczątków ludzkich, wytworów rytualnych:

- wystawy, muzea i inne obiekty dokumentujące ludobójstwo, Holokaust, zbrodnie, wojny, ataki terrorystyczne, morderstwa itp.;

- wystawy, muzea i inne obiekty dokumentujące działania, następstwem których była śmierć (niewolnictwo, więziennictwo, przymus, choroby, katastrofy, kataklizmy);

- wystawy, muzea i inne obiekty gromadzące materialne i niematerialne elementy kultury śmierci, do których zaliczamy przedmioty i tradycje związane z rytuałem odejścia i pogrzebu;

- miejsca gromadzące szczątki ludzkie (mumie, szczątki kostne, zabezpieczone narządy, fragmenty ciała itp.);

- zachowane, zabezpieczone, niezmienione przestrzenie, obiekty dokumentujące kres życia (budynki, ruiny, krajobrazy).

Ta kategoria tanatoturystyki, jej cel i przedmiot zainteresowania jest najpopularniejszą jej odmianą, powszechnie akceptowaną, choć wzbudzającą kontrowersje, szczególnie w przypadku komercyjnego wykorzystania doku- 
mentów śmierci. Obejmuje przede wszystkim wycieczki edukacyjne i poznawcze, choć należy do nich zaliczyć również wycieczki mające zabarwienie sensacyjne i motywowane "chorobliwą ciekawością", skrajnie - rozrywką.

3. Pamięcią o śmierci - turysta odwiedza miejsca upamiętniające życie (istoty, przedmioty, których już nie ma) i śmierć (przyczyny i sposób zakończenia życia); zaliczamy do tej kategorii obiekty tworzące przestrzeń pamięci:

- miejsca pochówku, takie jak cmentarze, groby, krypty, katakumby, ossuaria, świadczące o zgromadzonych szczątkach zindywidualizowanych lub anonimowych;

- pomniki, mauzolea, będące symbolicznym upamiętnieniem życia, działalności i śmierci człowieka (również zwierząt i roślin);

- świątynie, stanowiące przestrzeń grzebalną, symboliczną, religijną, w której zgromadzone są wytwory kultury śmierci;

- krajobrazy, przestrzenie świadczące o minionym życiu (zdegradowane środowisko, zrewitalizowana przestrzeń).

Równie popularna kategoria tanatoturystyki, wynikająca ze wspomnienia życia przerwanego śmiercią, to zainteresowanie architekturą sepulkralną oraz religią. Może odbywać się $\mathrm{w}$ nieświadomości turysty, który jeżeli nie jest przygotowany do odbioru przestrzeni $\mathrm{w}$ kategoriach tanatoturystycznych (poza miejscami pochówku), nie będzie wiązał tych podróży ze śmiercią, a raczej z minionymi wydarzeniami i krajobrazami (sentymentalnie).

4. Inscenizacją śmierci - kategoria podróży tanatoturystycznych, podczas których turysta ma kontakt zarówno z następstwami realnej śmierci, jak i ze śmiercią nierealną (fikcyjną); są to:

- wydarzenia kulturalne mające na celu rekonstrukcję zdarzeń historycznych, w których miała miejsce śmierć (rekonstrukcje historyczne bitew, pogromów);

- wydarzenia kulturalne lub religijne związane z obowiązującymi tradycjami, podczas których rekonstruowane jest cierpienie i akt śmierci (w Kościele rzymskokatolickim wielkanocna Droga Krzyżowa), pątnictwo, samookaleczenie, oraz inne tradycje, w których śmierć odgrywa istotną rolę, takie jak obrzędy związane z Dniem Zmarłych, Wszystkich Świętych, Halloween, voodoo, obrzędy pogrzebowe;

- przedstawienia artystyczne, w których śmierć odgrywa istotną rolę (wytwory sztuki artystycznej i ludowej - spektakle teatralne, film, literatura, rzeźba, malarstwo, pieśń, kulinaria, ubiór);

- wszelkie inscenizacje, obiekty i makiety nawiązujące do śmierci, mające na celu wzbudzenie określonych emocji - współczucia, empatii, żalu, strachu, przerażenia, odrazy. 
Jest to kategoria tanatoturystyki, która obejmuje elementy zarówno sacrum, jak i profanum - od religijnego obrzędu przejścia, po popkulturową rozrywkę.

5. Rekreacją - kategoria tanatoturystyki obejmująca pobyt rekreacyjny, wypoczynkowy, kontemplacyjny w określonych przestrzeniach śmierci traktowanych jako oazy spokoju, ciszy lub rozrywki i zabawy; do tej kategorii zalicza się:

- cmentarze, parki i pola pamięci, zadrzewione, z oprawą roślinną i artystyczną, układem alei nastrajających do spaceru i rekreacji (rekreację w tym przypadku należy rozumieć jako regenerację sił psychicznych i fizycznych, której formą jest spacer, a zachowanie człowieka niepozostające $\mathrm{w}$ konflikcie $\mathrm{z}$ normami przyjętymi w określonej kulturze, respektowanymi na obszarze nekropolii). Cmentarze stanowią wielokrotnie alternatywę dla parków miejskich, są przestrzeniami spotkań, terapii psychicznej po tragicznym zdarzeniu (Tanaś 2008b);

- przestrzenie rozrywki - miejsca rozrywkowe organizowane w celu wzbudzenia określonych emocji, np. strachu, przerażenia, odrazy, zabawy, ale również pełniące funkcje edukacyjne. Są to "fabryki mrocznej zabawy", muzea horroru, zamki strachu, sale tortur, obiekty gastronomiczne i noclegowe, szlaki turystyczne, fabularyzowane wycieczki, formy zabawy, w tle której jest śmierć (zabawa w wojnę, paintball). Mroczna rozrywka, źródłem której jest kultura śmierci, jej komercjalizacja, znaczenie i konsekwencje społeczne, może wzbudzać w określonych kręgach odbiorcy (turysta konserwatywny, postfiguratywny i kofiguratywny) kontrowersje oraz zainteresowanie i akceptację, szczególnie w kręgach prefiguratywnych, postnowoczesnych i liberalnych.

Tanatoturystykę należy zaklasyfikować do rodzaju turystyki poznawczej i edukacyjnej (motyw poznawczy, edukacyjny, wychowawczy, upamiętniający), w ramach turystyki kulturowej (przedmiotem zainteresowania jest kultura), której celem są miejsca mroczne, pierwotnie nieturystyczne (mroczna turystyka), w szczególności wytwory kultury śmierci. Jednocześnie tanatoturystykę można zaklasyfikować częściowo do turystyki religijnej (motyw religijny, zainteresowanie wytworami religii, cel pielgrzymkowy), turystyki rozrywkowej (zainteresowanie rozrywką) i krajoznawstwa (zainteresowanie lokalnym dziedzictwem) (rys. 43).

Zaproponowana klasyfikacja tanatoturystyki w szeroko rozumianej turystyce obejmuje też, w ograniczonym zakresie, turystykę wypoczynkową i specjalistyczną (kwalifikowaną) - np. cmentarz może pełnić funkcje rekreacyjne, a walory militarne mogą stanowić o specjalizacji (kwalifikacji) turystycznej. 


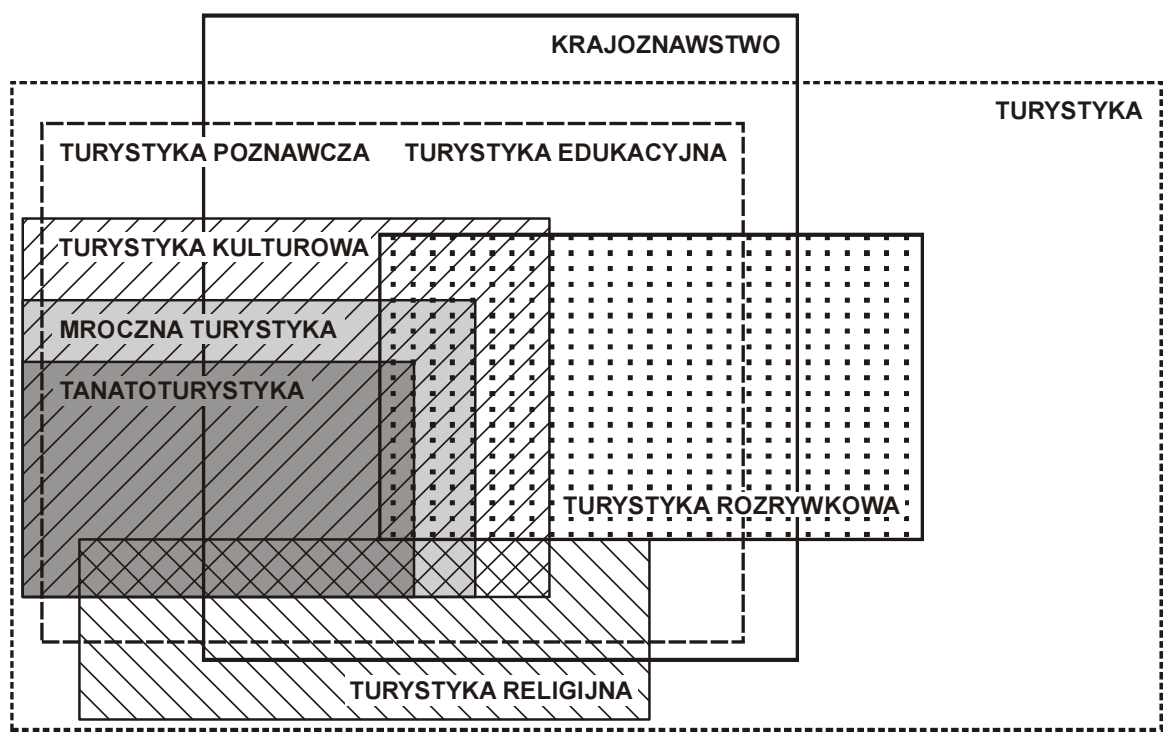

Rys. 43. Miejsce tanatoturystyki w klasyfikacji turystycznej kryterium motywu, celu i przedmiotu zainteresowania Źródło: opracowanie własne

P.R. STONE (2006), wykorzystując założenia R. SHARPLEY'A (2005), dokonał typologii mrocznej turystyki, która została opracowana na podstawie intensywności celów, jakie chcą osiągnąć zarówno dostawcy produktów turystycznych, jak i sami turyści. Jest to raczej swobodna interpretacja zjawiska zainteresowania turystycznego makabrą, jednak dająca wyobrażenie różnorodności i intensywności mrocznej turystyki, którą możemy określić wizyty w obiektach rozrywkowych, takich jak muzea horroru (najlżejsza kategoria tanatoturystyki), przez wizyty w muzeach ludobójstwa (ciężka kategoria tanatoturystyki), po pobyty $\mathrm{w}$ miejscach realnego zagrożenia życia (najcięższa kategoria tanatoturystyki). P.R. STONE (2006) stosuje określenia: „najjaśniejsza”, ,jaśniejsza”, ,jasna”, „ciemna”, „ciemniejsza”, „najciemniejsza” turystyka. W swej typologii wziął pod uwagę takie czynniki, jak: polityka, ideologia, autentyczność miejsca, cel wizyty, czas, oferta, infrastruktura (rys. 44).

$\mathrm{Na}$ podstawie skonstruowanego spektrum czynników kształtujących mroczną turystykę P.R. STONE (2006) wyodrębnił siedem jej typów:

Typ I: Dark Fun Factories (fabryki mrocznej zabawy) to obiekty i atrakcje, które mają wybitnie charakter rozrywkowy i komercyjny, a prezentują inscenizowaną śmierć i makabryczne sceny. Ten rodzaj produktów turystycznych charakteryzuje wysoki stopień zagospodarowania turystycznego. W związku z tym w typologii takie miejsca zajmują "najjaśniejsze" pole spektrum mrocznej turystyki. „Fabryki mrocznej zabawy” oferują produkty mało 
autentyczne i popkulturowe, przeznaczone dla masowego odbiorcy. Przykładem są Centra Dungeon organizowane w Europie przez Merlin Entertainments Group, muzea horroru (zorganizowane też w Polsce w Wojnowicach) czy liczne obwoźne lub stałe wystawy narzędzi tortur, których jedynym celem jest wzbudzenie emocji, przerażenia i zabawa.

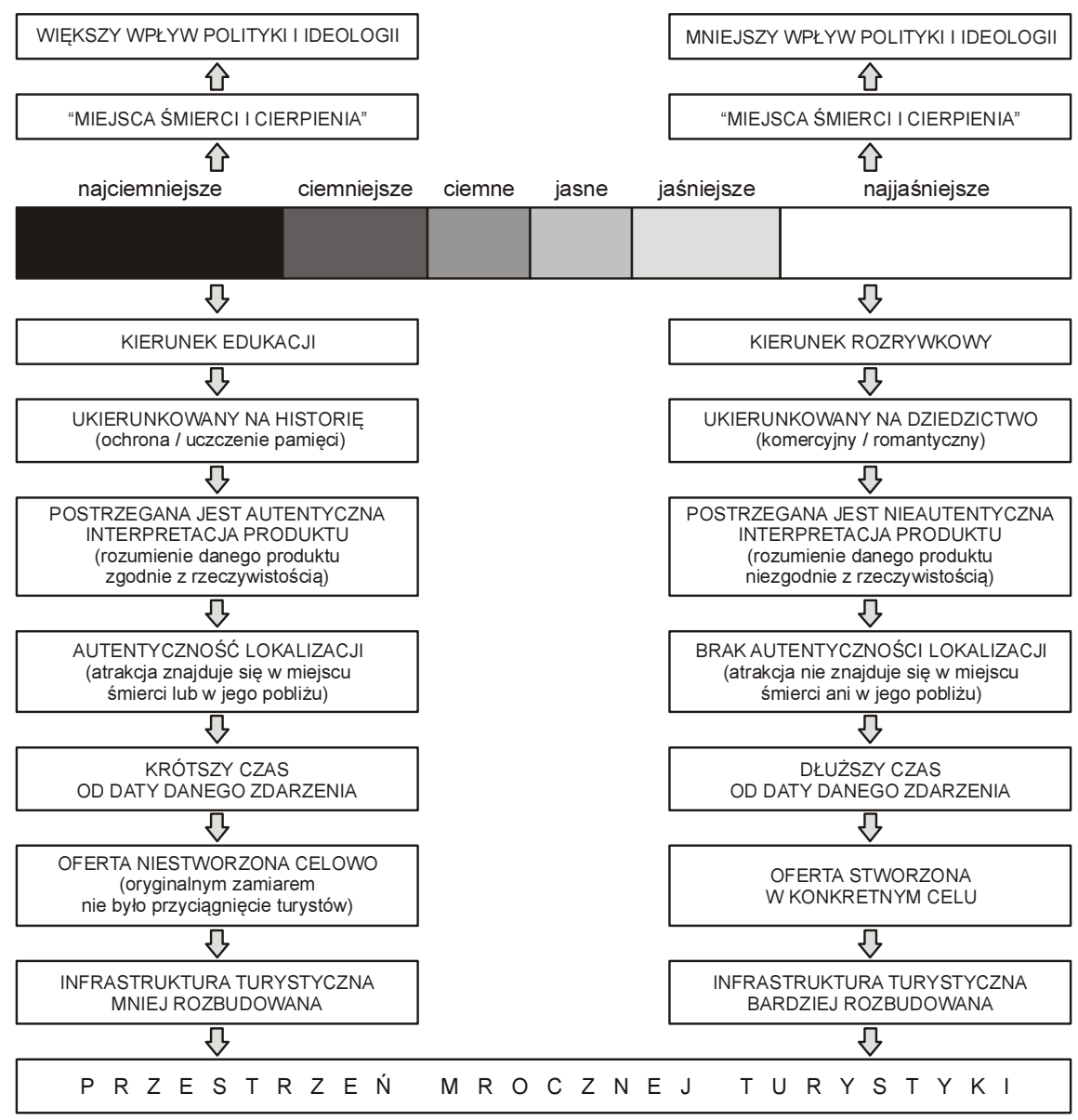

Rys. 44. Spektrum mrocznej turystyki

Źródło: na podstawie P.R. Stone (2006, za: KOMSTA 2013)

Typ II: Dark Exhibitions (mroczne wystawy) to wystawy i miejsca, które mają na celu edukacje poprzez rozrywkę. „Mroczne wystawy” oferują artefakty, które koncentrują się wokól śmierci, cierpienia i makabry, jednocześnie mając edukacyjny charakter. Dlatego obiekty te są postrzegane jako bardziej autentyczne, tym samym można je określić jako „jaśniejsze” pole spek- 
trum. Obiekty te są przygotowane do masowej obsługi i popularnonaukowego przekazu określonej wiedzy. Przykładowe obiekty to wystawy Body Worlds, katakumby kapucynów w Palermo i Neapolu.

Typ III: Dark Dungeons (mroczne lochy) miejsca prezentujące aspekty kar cielesnych, kar śmierci czy cierpienia ludzkiego w więzieniach i niewoli. "Mroczne lochy", prezentując dziedzictwo kulturowe i historię wymiaru sprawiedliwości oraz niewolnictwa, plasują się w ",jasnym" i "ciemnym" spektrum mrocznej turystyki.

Typ IV: Dark Resting Places (mroczne miejsca spoczynku) to głównie cmentarze, ossuaria, krypty grobowe. Wartość tych obiektów jest głównie historyczna i artystyczna. Są to miejsca upamiętniające zmarłych, prezentujące sztukę sepulkralną, stanowią jednocześnie istotne dziedzictwo kulturowe; pełnią funkcje poznawcze i krajoznawcze. Jednak tego typu miejsca są również wykorzystywane $\mathrm{w}$ celach rekreacyjnych, $\mathrm{np}$. zabytkowe zielone cmentarze (TANAŚ 2008b), oraz w celach rozrywkowych, szczególnie w krajach anglosaskich, gdzie organizowane są fabularyzowane wycieczki mające na celu wywołanie dreszczu emocji lub zobaczenie oryginalnej architektury cmentarnej łączonej z pozycją zmarłego. $Z$ tego względu "mroczne miejsca spoczynku" należy przyporządkować do „ciemnego" i ,jasnego" spektrum mrocznej turystki.

Typ V: Dark Shrines (mroczne kaplice) są lokalizowane blisko miejsca śmierci i powstają w krótkim czasie. Większość tego typu obiektów jest nieturystyczna, pobudowana $\mathrm{w}$ celu upamiętnienia zmarłego i aktu śmierci. Będą to zarówno kaplice grobowe, powypadkowe krzyże przydrożne czy pomniki pamięci. Autentyczny i aktualny charakter tych miejsc plasuje je w „ciemniejszym" spektrum.

Typ VI: Dark Conflict Sites (mroczne miejsca konfliktu) to miejsca historyczne związane $\mathrm{z}$ wojną. Pola bitew były jedną z pierwszych przestrzeni śmierci odwiedzanych turystycznie. Do grupy tej można również zaklasyfikować miejsca ataków terrorystycznych. Cechuje te miejsca często wysoka komercjalizacja i zagospodarowanie turystyczne, z tego względu mogą być klasyfikowane jako ,jaśniejsze" spektrum. Przykładami są tu zarówno turystycznie zagospodarowane pola bitew, jak i wydarzenia plenerowe typu rekonstrukcji wojennych.

Typ VII: Dark Camps of Genocide (mroczne obozy ludobójstwa) to obiekty zajmujące "najciemniejsze” spektrum mrocznej turystyki. Są to miejsca ludobójstwa, masowej śmierci, zbrodni i katastrof. Znajdują się w autentycznym miejscu śmierci i odznaczają się wysokim stopniem ideologii politycznej.

Poszczególne typy obiektów mrocznej turystyki w zależności od komercjalizacji, zagospodarowania, autentyczności i celowości mogą być umiesz- 
czane w sąsiednich spektrach mrocznej turystyki. Jednak im bardziej przestrzeń śmierci jest autentyczna i aktualna, tym spektrum bardziej ciemne.

R. SHARPLEY (2005) opracował typy mrocznej turystyki w oparciu o podaż mrocznych atrakcji i emocji. Te różnią się $\mathrm{w}$ zależności od przypadkowości i celowości podaży i popytu rynkowego. Wyróżnił grupę walorów, które są niezorganizowane i odkrywane przez turystów przypadkowo lub celowo, oraz grupę atrakcji przygotowanych do odbioru, lecz odwiedzanych przypadkowo lub celowo. W ten sposób określił mroczną turystykę stosując nomenklaturę jasnej, szarej i czarnej turystyki, określającej stopień komercjalizacji atrakcji.

Autor dokonał własnej typologii tanatoturystyki w zależności od stopnia zainteresowania kulturą śmierci i jej podażą turystyczną (rys. 45).

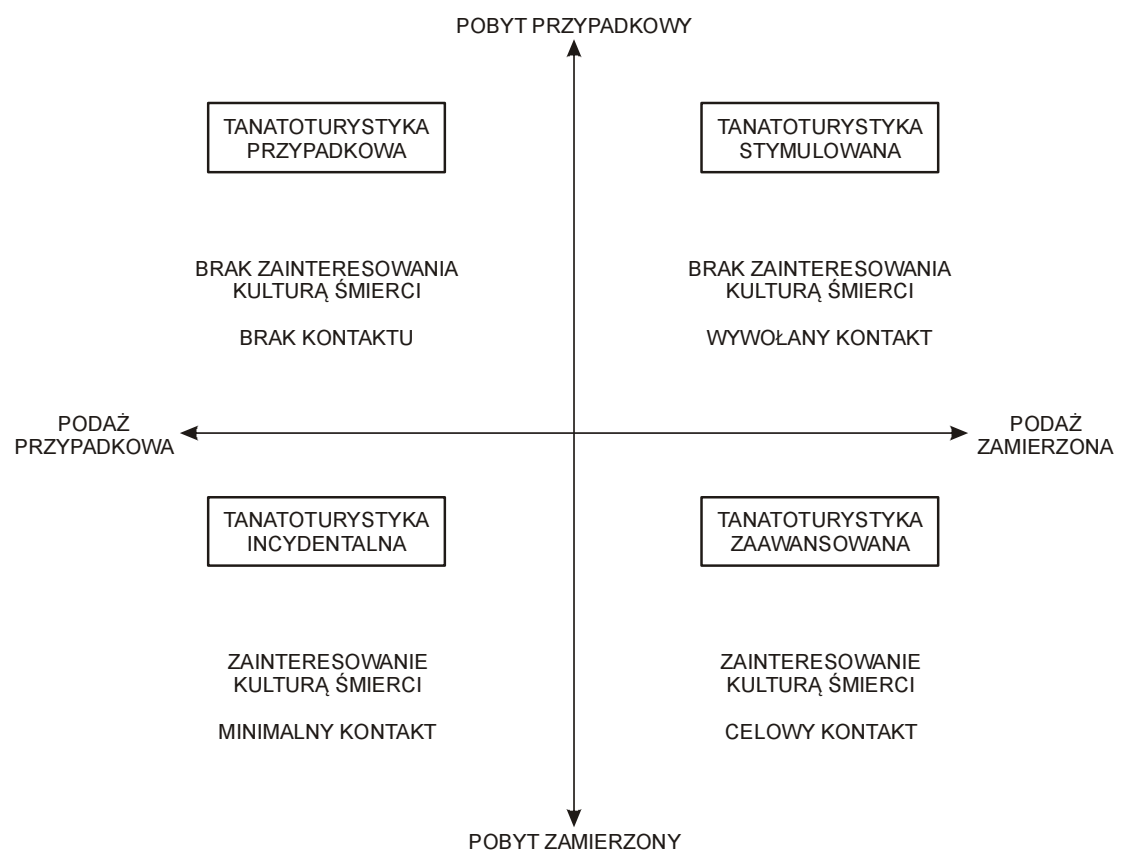

Rys. 45. Typy tanatoturystyki w zależności od popytu i podaży kultury śmierci Źródło: opracowanie własne

W zależności od stopnia zainteresowania kulturą śmierci lub jej brakiem (popytem) oraz podażą kultury śmierci, zamierzoną lub przypadkową, autor wyróżnia cztery typy tanatoturystyki.

Typ I: tanatoturystyka przypadkowa - turysta niezainteresowany kulturą śmierci trafia na jej wytwory, które nie zostały celowo wyeksponowane. 
Świadomy kontakt z wytworami kultury śmierci jest przypadkowy lub praktycznie nie występuje (np. przypadkowy pobyt na cmentarzu).

Typ II: tanatoturystyka incydentalna - turysta zainteresowany kulturą śmierci trafia na jej wytwory, które nie zostały celowo wyeksponowane. Świadomy kontakt $\mathrm{z}$ wytworami kultury śmierci jest przypadkowy (np. odkrycie ciekawego grobowca).

Typ III: tanatoturystyka stymulowana - turysta niezainteresowany początkowo kulturą śmierci, trafia na jej wytwory, które zostały celowo wyeksponowane. Świadomy kontakt z wytworami kultury śmierci zależy od stopnia wzbudzenia zainteresowania, wynikającego z bezpośredniego kontaktu z przygotowanymi do odbioru wytworami kultury śmierci (np. przypadkowa wizyta w muzeum).

Typ IV: tanatoturystyka zaawansowana - turysta zainteresowany kulturą śmierci trafia na jej wytwory, które zostały celowo wyeksponowane. Świadomy kontakt $\mathrm{z}$ wytworami kultury śmierci jest celowy (np. zamierzona wizyta na zabytkowym cmentarzu).

Wyróżnione przez autora typy tanatoturystyki obejmują zarówno działania organizatorów przestrzeni turystycznej, zmierzające do kształtowania podaży walorów kulturowych $\mathrm{w}$ postaci atrakcji lub produktów turystycznych, jak i podejmowane aktywności turystów określające popyt turystyczny. Typy I i III tanatoturystyki obejmujące działania przypadkowe lub stymulowane, mogące dopiero wykształcić świadome zainteresowanie kulturą śmierci, oraz typy II i IV charakteryzujące działania zamierzone, świadczące o turystycznym zainteresowaniu wytworami kultury śmierci, a wynikające z określonego popytu, wskazują na potrzebę dalszych badań i analiz proporcji i przestrzennych aspektów wyodrębnionych typów tanatoturystyki.

Przyporządkowanie turysty odwiedzającego przestrzeń śmierci do określonego typu tanatoturystyki jest uzależnione od stopnia jego świadomości i zainteresowania kulturą śmierci oraz działań marketingowych, promujących przestrzenie śmierci $w$ kategoriach atrakcji i produktów turystycznych.

\subsection{GEOGRAFIA TANATOTURYSTYKI}

Ponieważ geografia tanatoturystyki jest nową subdyscypliną naukową, dlatego należy podjąć próbę jej konceptualizacji i stworzenia konceptualnego modelu przedmiotowego w postaci wstępnej teorii. Z. CHOJNICKI (2010, s. 21) nazywa wstępny proces tworzenia teorii preteorią przedmiotową, zawierającą konceptualne modele przedmiotowe oraz kluczowe pojęcia teoretyczne 
i tezy, których odniesienie przedmiotowe określa charakter i zakres dyscypliny naukowej. Temu służą ustalenie problemów badawczych, celów i hipotez. Problem badawczy może zostać wyrażony w aspektach przedmiotowopoznawczym i metodologiczno-poznawczym, wynikających z braku wiedzy i możliwości jej uzyskania przez badania naukowe. Autor w rozważaniach nad tanatoturystyką przyjął humanistyczny model wyjaśniania i rozumienia fenomenologicznego, sprowadzający się do ujawnienia sensu ludzkich zachowań i wytworów.

Pozycja, jaką w nauce ma każda dyscyplina naukowa zależy od jej postępu poznawczego i problemowego oraz od jej wkładu w rozwój innych nauk. Żadna działalność naukowa nie może być izolowana od innych dyscyplin naukowych. Zdaniem Z. CHOJNICKIEGO (2010, s. 14) geografia budzi zbyt małe zainteresowanie swoimi koncepcjami i wynikami. Dlatego tak istotne jest wiązanie metod i problemów badawczych geografii $z$ innymi dyscyplinami należącymi do dziedziny nauk spolecznych i humanistycznych (np. z kulturoznawstwem, etnografią, antropologią kultury, socjologią).

Tanatoturystyka wyodrębniona $\mathrm{z}$ turystyki kulturowej na podstawie przedmiotu turystycznego zainteresowania, jakim jest kultura śmierci i przestrzeń śmierci, wymaga dalszych analiz przestrzennych mających na celu identyfikację przestrzeni tanatoturystyki. Wobec tego należy zastanowić się nad metodologią specjalności badającej geograficzny aspekt podróży tanatoturystycznych, którą można nazwać geografią tanatoturystyki, ściśle powiązaną z geografią kultury i geografią turyzmu.

U podstaw nowej geografii kultury znajduje się koncepcja kultury, która odwołuje się do mechanizmu społecznego przekazu wzorów i wartości kulturowych. Geografia kultury badając przestrzenne aspekty życia człowieka próbuje zrozumieć, jak ludzie żyją $\mathrm{w}$ świecie, jak z niego korzystają, jak kształtują go zgodnie ze swoimi wyobrażeniami, i w jaki sposób nadają mu sens. Istotnym problemem badawczym geografii kultury jest również organizacja krajobrazów, będących wyrazem określonej kultury, oraz wpływ tych krajobrazów na ludzi. Zadaniem geografii kultury jest zastanowienie się nad fundamentalnymi cechami organizacji i doświadczeń przestrzeni, dzięki którym można odtworzyć obraz wierzeń religijnych, mitologii i ideologii (REMBOWSKA 2002b). Geografowie kultury podejmują trud wyjaśnienia oraz zrozumienia sposobów użytkowania ziemi i systemów organizacji społecznych mających lokalny i globalny zasięg. Geografowie powinni przyjrzeć się, jak system symbolicznych obrazów wpływa na konstrukcję rzeczywistości społecznej, percepcję i przeżywanie przestrzeni przez człowieka, również turysty. Może być to pomocne $\mathrm{w}$ zrozumieniu różnic między przestrzenią sacrum a profanum. Geograficzne badania kulturowe są przydatne w prze- 
strzennych analizach tożsamości kultur, a z perspektywy współczesnego wpływu kultury masowej na życie człowieka w opisie procesu desakralizacji kultur Zachodu.

Nawiązując do postulatów badawczych geografii kultury wyrażonych przez K. REMBOWSKĄ (2002b) należy określić postulaty badawcze geografii tanatoturystyki, które w części nawiązują do objaśnionych wcześniej założeń geografii śmierci i geografii turyzmu. Wykorzystując zaproponowaną wcześniej koncepcję rozwoju kulturowej przestrzeni turystycznej oraz powszechne w geografii społeczno-ekonomicznej metody badawcze można przyjąć następującą problematykę badawczą geografii tanatoturystyki, której głównym przedmiotem jest przestrzenna (geograficzna) analiza:

- potrzeb i motywów, które determinują podróże turystyczne do przestrzeni śmierci;

- mechanizmów społecznego przekazu wzorów i wartości kulturowych występujących $\mathrm{w}$ turystyce, a określających miejsce śmierci w życiu człowieka;

- zróżnicowania wierzeń religijnych, mitologii i ideologii nadających turystyczny charakter kulturze śmierci;

- walorów, atrakcji i produktów turystycznych opartych na kulturze śmierci.

Konsekwencją zmian zachodzących w kulturowej przestrzeni turystycznej jest sposób organizacji przestrzeni śmierci na potrzeby turystyki. Zróżnicowana i relatywna oryginalność kultury śmierci oraz społeczna tożsamość kulturowa należą do głównych czynników decydujących o wykorzystaniu przestrzeni śmierci na potrzeby turystyki.

Wyjaśnianie zarejestrowanych $\mathrm{w}$ przestrzeni geograficznej zjawisk turystycznych nie może sprowadzać się tylko do schematu logicznego wnioskowania, powinno również odbywać się przez wykrywanie i analizowanie czynników determinujących, np. podażowych i popytowych uwarunkowań kulturowych, stopnia zagospodarowania turystycznego, przyczyn i skutków organizacji produktów turystycznych opierając się na kulturze śmierci. Ukulturowienie badań geograficznych tanatoturystyki sprzyja pogłębionej analizie i wyjaśnianiu procesów zachodzących $\mathrm{w}$ przestrzeniach śmierci pod wpływem ruchu turystycznego.

Geografia tanatoturystyki jest dziedziną przedmiotową geografii społeczno-ekonomicznej, której przedmiotem badań jest zjawisko tanatoturystyki, czyli podróży turystycznych do przestrzeni śmierci. Ściślej określając przedmiot zainteresowania badawczego należy powiedzieć, że jest nim kultura śmierci i turystyka. Podobnie jak w przypadku geografii śmierci i nekrogeografii, również w geografii tanatoturystyki mają zastosowanie metody 


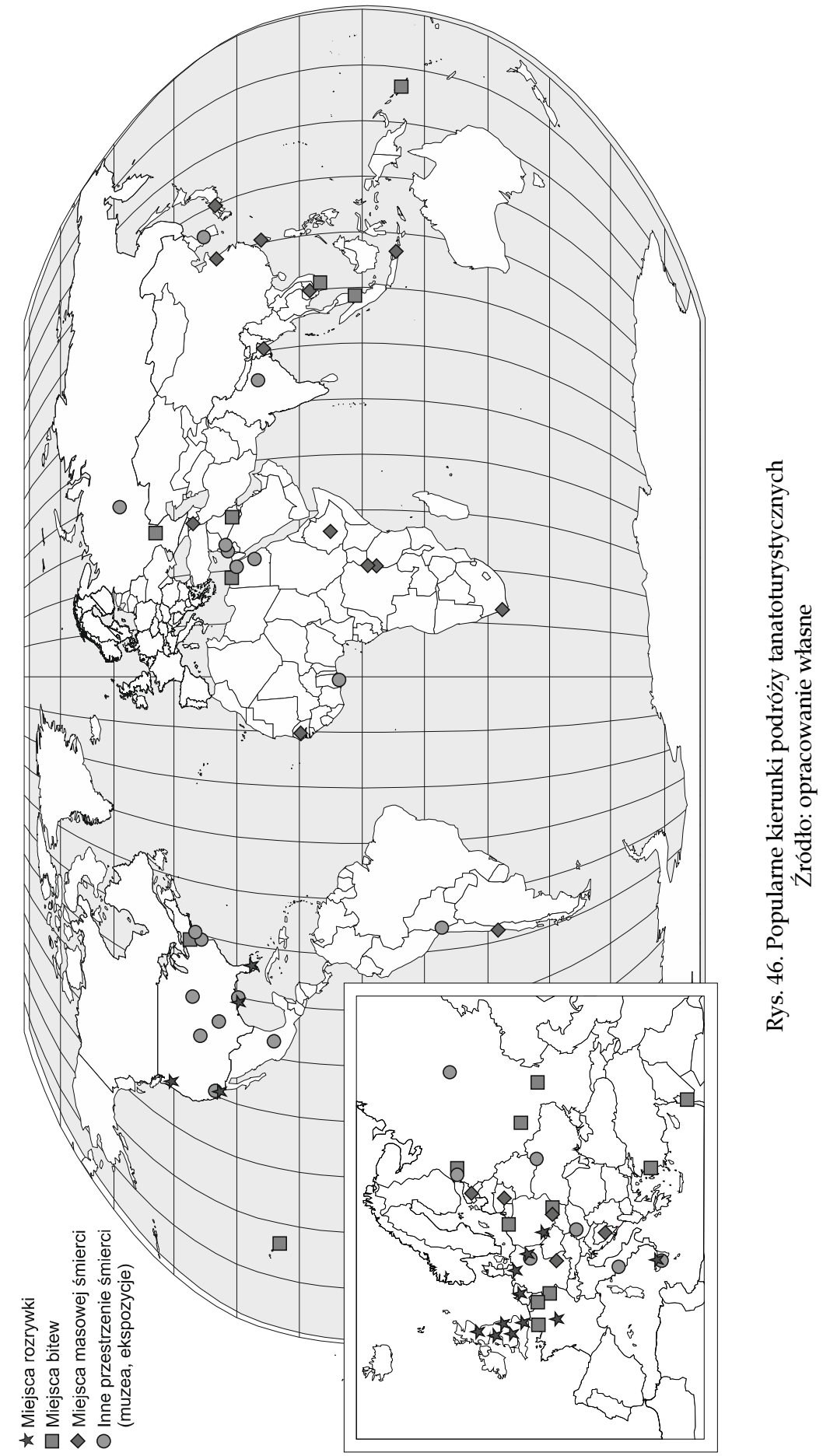


badawcze geografii społeczno-ekonomicznej, wykorzystywane w badaniach nad problematyką środowiska życia człowieka i zagospodarowania przestrzennego, oraz praktyczne narzędzia analiz przestrzennych, jak np. narzędzia GIS. Tak więc $w$ badaniach nad geografią tanatoturystyki należy korzystać przede wszystkim ze znanych $\mathrm{w}$ geografii turyzmu metod badawczych (KOWALCZYK 2000), z wykorzystaniem metodologii geografii kultury (REMBOWSKA 2002a). Ponadto pomocne w wyjaśnieniu i rozumieniu kulturowych zjawisk w turystyce będą metody badawcze znane w naukach społecznych i humanistycznych.

Geografia zasobów, walorów, atrakcji i produktów turystycznych bazujących na wytworach kultury śmierci jest trudna i skomplikowana. Właściwie podporządkowana jest dwóm grupom czynników - podażowym i popytowym. Czynniki podażowe, podporządkowane są normom i determinantom społeczno-kulturowym, w szczególności religijnym i politycznym. Czynniki popytowe wynikają z potrzeb i motywów określonych grup społecznych, uzależnionych od rozwoju cywilizacyjnego, w szczególności społeczno-gospodarczego.

Czynniki podażowe określają kierunki aktualnych i potencjalnych podróży tanatoturystycznych, które związane są przede wszystkim ze specyfiką kulturową lub religijną określonych grup społecznych. Z tego względu można wyróżnić obszary religijne, które mają potencjał poznawczy kultury śmierci, wyrażający się m.in:

- charakterem cmentarzy, ich założeniami przestrzennymi, funkcjami i sztuką sepulkralną;

- ossuariami gromadzącymi szczątki kostne i mumie;

- publiczną ekspozycją relikwii w postaci zmumifikowanych zwłok lub ich fragmentów;

- obrzędowością pogrzebową i sposobem traktowania zwłok;

- historycznym charakterem miejsc pamięci;

- sposobem świętowania i traktowania śmierci w życiu społeczno-kulturowym.

Czynniki popytowe określają obszary generujące ruch turystyczny do przestrzeni śmierci, do których należą w szczególności państwa rozwinięte. Mieszkańcy tych terenów interesują się wieloma aspektami kulturowej różnorodności świata, jednocześnie ze względu na powszechne tabu śmierci, rytuał pogrzebowy i oryginalność postępowania ze zmarłymi wzbudzają ich szczególne zainteresowanie. Popkulturowy charakter przekazu kreuje natomiast potrzebę kontaktu $\mathrm{z}$ artefaktami śmierci o charakterze rozrywkowym lub potrzebę kontaktu z obszarami generującymi bezpośrednie zagrożenie życia (rys. 46). 


\section{WNIOSKI}

Turystyka w przestrzeni śmierci stanowi o współistnieniu i wzajemnym przenikaniu się sacrum i profanum. Ze względu na przejściowy charakter kontaktu kulturowego w trakcie podróży turystyka może prowadzić do konfliktów społecznych, wynikających nie z samego połączenia sfer sacrum i profanum, lecz z postaw turystów wobec określonych wartości. Zainteresowanie turysty przestrzenią śmierci bez odpowiedniego przygotowania merytorycznego i mentalnego może prowadzić do jej błędnej interpretacji, co szczególnie jest widoczne $\mathrm{w}$ obiektach będących popularnymi atrakcjami turystycznymi (np. Kaplica Czaszek w Czermnej, katakumby paryskie), które oceniane są zazwyczaj przez pryzmat popkulturowej teatralizacji lub historycznego kiczu (fot. 24, 25).

Dlatego ocena podróży tanatoturystycznych nie jest prosta i jest uzależniona w szczególności od motywów tych podróży. Negatywna ocena tanatoturystyki może wynikać może $\mathrm{z}$ dystansu kulturowego pomiędzy kulturą rodzimą a importowaną oraz z różnic społecznych i etnocentryzmu, mających istotne znaczenie $w$ interpretowaniu zjawisk nowych lub nieznanych.
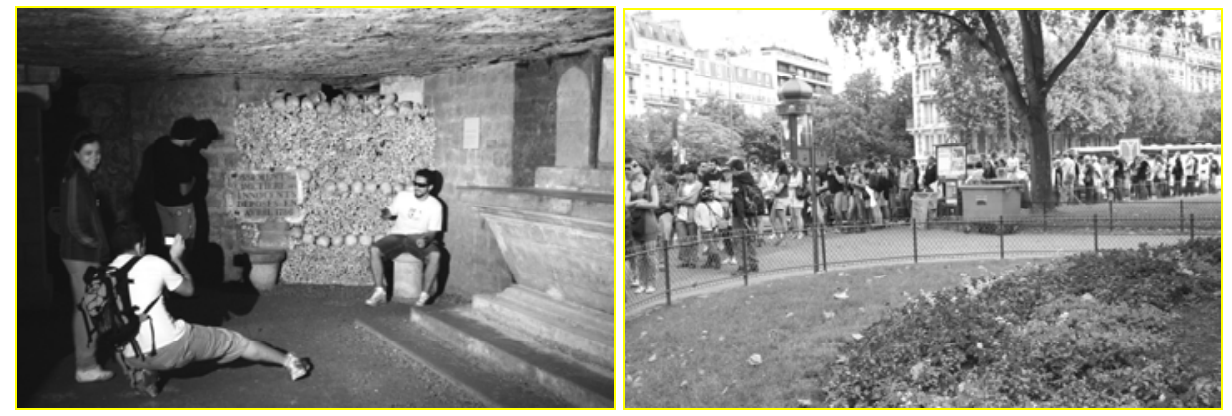

Fot. 24, 25. Ossuarium w katakumbach paryskich i kolejka turystów do wejścia (autor: S. Tanaś)

Tanatoturystyka może prowadzić do przemian społeczno-kulturowych w takich dziedzinach, jak: 
- funkcjonowanie instytucji społecznych (ochrona cmentarzy, działalność konserwatorska, zachowanie obrzędowości i tradycji żałobnych, zagospodarowanie turystyczne przestrzeni śmierci);

- postawy i zachowania społeczne (postawa wobec śmierci, pedagogika śmierci, dbałość o miejsca pochówku i pamięć, heterogeniczność kulturowa, tolerancja, przychylność, izolacja);

- kultura zbiorowości lokalnej (zachowanie tożsamości, rozwój kultury regionalnej, laicyzacja sacrum).

Tanatoturystyka jest zjawiskiem społeczno-przestrzennym wynikającym z zainteresowania odbiorcy przestrzenią śmierci i samą śmiercią, wywołującego potrzebę podróży. Jest rodzajem działalności polegającej na umiejętnym odczytywaniu symboliki przestrzeni śmierci wraz z całym zasobem kodów, za pomocą których przestrzeń śmierci jest „napisana”. Charakter tego zainteresowania jest konsekwencją zmian kulturowych, jakie zachodziły w historii ludzkości, nawarstwiających się w obrazach, gestach i pamięci, a współcześnie stanowiących przedmiot zainteresowania poznawczego materialną sztuką sepulkralną i duchowymi aspektami pamięci i obrzędowości.

Tanatoturystyka prowadzi do interpretacji przestrzeni śmierci, a więc do przybliżenia znaczenia, wyjaśnienia i tłumaczenia przedmiotu poznania. Interpretacja jest aktywnością edukacyjną, której celem jest wyjaśnienie znaczeń i zależności poprzez wykorzystanie bezpośrednich doświadczeń i oryginalnych obiektów (KRUCZEK, KUREK, NOWACKI 2007). Siła interpretacji polega na zdolności do głębszego zrozumienia poznawanego zjawiska czy obiektu. Przestrzeń śmierci zmusza do jej interpretacji, która jako proces edukacyjny zależy od wartości przekazu, stanowiącego podstawę poznania. Zasadniczym celem interpretacji przestrzeni śmierci powinno być zrozumienie jej sensu, wykształcenie wrażliwości wobec niej i „śmierci drugiego" pomagających $\mathrm{w}$ zrozumieniu historii i semiotyki śmierci.

Organizowanie zajęć dydaktycznych lub wychowawczych w określonych przestrzeniach śmierci wzmacnia przekaz historyczny, światopoglądowy, religijny i socjalizacyjny (TANAŚ 2012). Nauka historii i geografii historycznej w miejscach upamiętniających śmierć, szczególnie poprzez bezpośredni kontakt z przestrzenią kulturową, wspiera proces budowania tożsamości narodowej i obywatelskich postaw. Sprzyja temu odpowiednio przygotowana infrastruktura turystyczna, służąca propagowaniu wiedzy historycznej i kulturowej, oraz zrozumienie działań instytucji pracujących na rzecz ochrony i zachowania dziedzictwa kulturowego. Dlatego, zdaniem autora, należy zwrócić szczególną uwagę na krajoznawczy aspekt tanatoturystyki, która prowadzi do kształtowania pożądanych postaw społecznych 
wobec człowieka i środowiska przyrodniczego, w szczególności postaw patriotycznych i humanistycznych.

Przeprowadzone analizy wskazują na możliwości wykorzystania w ramach tanatoturystyki potencjału kultury i przestrzeni śmierci. Ukazują rosnącą popularność wycieczek do przestrzeni śmierci motywowanych edukacją, pamięcią i wiarą, ale również potrzebą rozrywki. Szczególnie popkulturowa forma interpretacji kultury śmierci może rodzić moralny opór i krytykę. Obawy te, zdaniem autora, nie są w pełni uzasadnione. Przytoczone $\mathrm{w}$ książce przykłady potwierdzają, że kontakt z kulturą śmierci, również w wymiarze masowym, rodzi, choć nie koniecznie, pozytywne skutki socjalizacyjne, pod warunkiem odpowiedniego przygotowania odbiorcy do interpretacji skomercjalizowanego produktu. Obawy mogą wzbudzać podróże motywowane potrzebą bezpośredniego i świadomego kontaktu z cierpieniem i śmiercią, wybiegające poza ustalone normy etyczno-moralne.

Zróżnicowanie geograficzne oraz historyczna ewolucja kultur stanowią o współczesnym zainteresowaniu turystycznym dziedzictwem kultury, w tym dziedzictwem kultury śmierci. To z kolei jest czynnikiem wpływającym na urynkowienie turystyki kulturowej, czego przykładem jest również tanatoturystyka, uwzględniająca specyfikę motywów podróży. Tanatoturystyka rozwija się w świecie zachodnim od XIX wieku, choć podróże, które można zaklasyfikować jako tanatoturystyczne, były udokumentowane znacznie wcześniej. $\mathrm{W}$ drugiej połowie $\mathrm{XX}$ wieku, wraz $\mathrm{z}$ rozwojem kultury popularnej i mass mediów, nastąpił gwałtowny rozwój produktów turystycznych organizowanych na bazie kultury śmierci, wraz z kontrowersyjnie i moralnie wątpliwą potrzebą bezpośredniego lub pośredniego kontaktu ze śmiercią. Zmiany społeczne i kulturowe prowadzą do zmian preferencji turystycznych, $\mathrm{w}$ tym do zainteresowania turysty pierwotnie nieturystycznymi przestrzeniami, które z czasem nabierają charakteru indywidualnej lub zagospodarowanej przestrzeni turystycznej. Z tego wnioskować można, że związki przestrzeni śmierci z przestrzenią turystyczną mogą być trwałe, a w aspekcie ekonomicznym skutkować organizacją produktów turystycznych.

Jednym z zagadnień badawczych poruszonych przez autora była nekrogeografia i geografia śmierci. Działalność naukowa prowadzona $w$ ramach wymienionych subdyscyplin powinna prowadzić do określenia metod służących rozwiązaniu problemów naukowych, których przedmiotem będą (CHOJNICKI 2010, s. 152):

- relacje między środowiskiem geograficznym, determinowanym w szczególności czynnikami kulturowymi (np. wytworami kultury śmierci), a człowiekiem; 
- identyfikacja i badanie oddziaływań w aspekcie przestrzennym (np. przestrzeń śmierci, przestrzenny aspekt kultury śmierci, przestrzeń tanatoturystyki);

- procesy społeczno-gospodarcze i fizycznogeograficzne w skali światowej i regionalnej, będące następstwem śmierci i kultury śmierci.

Odbywająca się $\mathrm{w}$ ramach nekrogeografii analiza przestrzenna cmentarzy - ich rozmieszczenia, wewnętrznej topografii - stwarza szerokie możliwości budowania wiedzy na temat lokalnej tożsamości, dziedzictwa i kultury. Zastosowanie w badaniu morfologii cmentarzy i ich przestrzennego rozmieszczenia narzędzi GIS umożliwia szybką i dokładną interpretację geograficzno-historyczną miejsc dokumentujących genealogię. Geografia śmierci, zajmująca się badaniem przestrzennego aspektu kultury śmierci, w połączeniu $\mathrm{z}$ innymi dyscyplinami naukowymi, może być pomocna $\mathrm{w}$ zrozumieniu różnic społecznych i kulturowych determinowanych czynnikami geograficznymi (dyfuzją i synkretyzmem kulturowym). W dobie globalnego kryzysu moralnego i konfliktów zbrojnych na tle religijnym, kulturowym, politycznym i gospodarczym geografia śmierci wyjaśnia przestrzenny charakter zagrożeń generowanych przez człowieka i determinujących jego życie, również jego zachowania turystyczne.

Reasumując, autor uważa, że śmierć rozumiana zarówno jako kres życia człowieka, składników biosfery i sfery nieożywionej Ziemi, krajobrazu, przestrzeni, przedmiotu, jak i zbiór wytworów kultury tworzących przestrzeń śmierci, odgrywają ważną rolę $\mathrm{w}$ kształtowaniu przestrzeni geograficznej, w szczególności tego jej fragmentu, który organizowany jest przez człowieka, a więc przestrzeni kulturowej, w tym przestrzeni turystycznej. Sposób organizacji przestrzeni śmierci wynika z przyjętych norm kulturowych. Jej składniki, a więc walory, mając wartość religijną, edukacyjno-wychowawczą, socjalizacyjną, emocjonalną, a nawet rozrywkową, kształtują stopień i charakter zainteresowania człowieka wobec niej. W szczególności postmodernistyczny sposób interpretacji dziedzictwa kulturowego wpłynął na wzrost zainteresowania przestrzenią śmierci $\mathrm{w}$ wymiarze artystycznym, rozrywkowym i sensacyjnym. Głównym czynnikiem determinującym tanatorurystykę jest wobec tego geograficzne zróżnicowanie przestrzeni śmierci i geograficzne zróżnicowanie jej interpretacji, wynikające z różnic kulturowych tak twórców, organizatorów, jak i konsumentów.

Autor wyraża nadzieję, że przedstawione teoretyczne analizy dotyczące przestrzeni śmierci, przestrzeni tanatoturystyki oraz tanatoturystyki będą pomocne $\mathrm{w}$ zrozumieniu turystycznego zainteresowania człowieka aspektami śmierci i procesów prowadzących do przekształcenia pierwotnie nieturystycznej przestrzeni śmierci w przestrzeń tanatoturystyki. 


\section{Literatura}

Adamkiewicz M., 2004, Oblicza śmierci. Propedeutyka tanatologii, Europejskie Centrum Edukacyjne, Toruń, ss. 470.

ADAMS K.M., 2003, Global cities, terror and tourism: the ambivalent allure of the urban jungle, [w:] R. Bishop, J. Phillips, W. Yeo (red.), Postcolonial Urbanism: Southeast Asian Cities and Global Processes, Routledge, London, s. 37-59.

ADAMSKI W., 1978, Wstęp do wydania polskiego, [w:] M. Mead (red.), Kultura i tożsamość. Studium dystansu międzypokoleniowego, PWN, Warszawa, ss. 147.

AlDSKOGIUS H., 1977, A conceptual framework and Swedish case study of recreational behavior and environmental cognition, "Economic Geography” 53(2).

AleXANDER J.C., 2010, Znaczenia społeczne. Studia z socjologii kulturowej, „Współczesne Teorie Socjologiczne" XVI, Zakład Wydawniczy Nomos, Kraków, ss. 540.

Alsarayreh M., JaWAbreh O., Helalat M., 2010, The influence of terrorism on the international tourism activities, „European Journal of Social Sciences” 13(1), s. 145-160.

ARIÈs P., 1979, Śmierć drugiego, „Teksty” 3 (45).

ARIÈs P., 1989, Człowiek i śmierć, Państwowy Instytut Wydawniczy, Warszawa, ss. 639.

ARIÈs P., 2007, Rozważania o historii śmierci, Oficyna Naukowa, Warszawa, ss. 335.

ARNOLD M., 1960, Emotion and Personality: Psychological Aspects, Columbia University Press, New York.

AsHWORTH G., 2002, Holocaust tourism: the experience of Krakow - Kazimierz, "International Research in Geographical and Environmental Education" 11(4), s. 363-367.

BACZWAROW M., NAPIERAŁA T., 2002, Wpływ wydarzeń 11 września 2001 r. na turystykę światowa, "Turystyka i Hotelarstwo" 1, s. 75-90.

Bagby P., 1975, Kultura i historia. Prolegomena do porównawczego badania cywilizacji, Państwowy Instytut Wydawniczy, Warszawa.

BAŃKO M. (red.), 2003, Wielki słownik wyrazów obcych, Wydawnictwo Naukowe PWN, Warszawa.

BARAŃSKI J., 2000, Śmierć i zmysty: doznania, wyobrażenia, przemijanie, Astrum, Wrocław, ss. 161.

BARKER C., 2005, Studia kulturowe. Teoria i praktyka, Wydawnictwo UJ, Kraków, ss. 569.

BAUMAN Z., 1996, Etyka ponowoczesna, Wydawnictwo Naukowe PWN, Warszawa.

BAUMAN Z., 1998, Śmierć i nieśmiertelność. O wielkości strategii i życia, Wydawnictwo Naukowe PWN, Warszawa.

BAUMAN Z., 2000a, Globalizacja, Państwowy Instytut Wydawniczy, Warszawa, ss. 158.

BAUMAN Z., 2000b, Ponowoczesność jako źródto cierpień, Wydawnictwo Sic!, Warszawa, ss. 389.

Bauman Z., 2003, Razem osobno, Wydawnictwo Literackie, Kraków.

Bauman Z., 2006a, Ptynna nowoczesność, Wydawnictwo Literackie, Kraków 2006, ss. 250.

BAUMAN Z., 2006b, Społeczeństwo w stanie oblężenia, Wydawnictwo Sic!, Warszawa, ss. 283. 
BaUman Z., 2007, Płynne życie, Wydawnictwo Literackie, Kraków, ss. 248.

BEECH J., 2000, The enigma of holocaust sites as tourism attractions - the case of Buchenwald, "Managing Leisure" 5(1), s. 29-41.

BEECH J., 2009, Genocide tourism, [w:] R. Sharpley, P.R. Stone (red.), The Darker Side of Travel: The Theory and Practice of Dark Tourism, Channel View Publications, Bristol, s. 207-223.

BERBEKA J. (red.), 2012, Turystyka martyrologiczna w Polsce na przykładzie Państwowego Muzeum Auschwitz-Birkenau, Proksenia, Kraków, ss. 177.

BILSKA-WODECKA E., 2003, Kalwarie europejskie. Analiza struktury, typów i genezy, IGiGP UJ, Kraków, ss. 192.

BLOM T., 2000, Morbid tourism: A postmodern market niche with an example from Althorpe, „Norwegian Journal of Geography" 54(1), s. 29-36.

BOLECHÓw B., 2002, Terroryzm w świecie podwubiegunowym, Wydawnictwo Adam Marszalek, Toruń, ss. 539.

Boorstin D., 1961, The Image: A Guide to Pseudo-Events in America, Harper Colophon, New York.

Bruneteau B., 2005, Wiek ludobójstwa, Oficyna Wydawnicza "Mówią Wieki”, Warszawa, ss. 224.

BucZKOWSKA K., MALCHROWICZ-MOŚKO E., 2012, Etyczne dylematy turystyki kulturowej, „Turystyka Kulturowa" 12, s. 42-55.

BUTLER R.W., 1980, The concept of a tourist area cycle of evolution: implications for management of resources, "The Canadian Geographer" 24(1), s. 5-12.

CAUSEVIC S., LYNCH P., 2011, Phoenix tourism: post-conflict tourism role, "Annals of Tourism Research" 38(3), s. 780-800.

ChabAnis C., 1987, Śmierć, kres czy początek?, Instytut Wydawniczy PAX, Warszawa, ss. 333.

CHOJNICKI Z., 1999, Podstawy metodologiczne i teoretyczne geografii, Bogucki Wydawnictwo Naukowe, Poznań, ss. 446.

CHOJNICKI Z., 2010, Koncepcje i studia metodologiczne i teoretyczne w geografii, Bogucki Wydawnictwo Naukowe, Poznań, ss. 184.

CHrOnis A., 2005, Co-constructing heritage at the Gettysburg Storyscape, "Annals of Tourism Research" 32(2), s. 386-406.

CHYLIŃSKA D., 2009, "Ciemne” oblicza turystyki kulturowej Dolnego Ślaska, [w:] K. Widawski (red.), Turystyka kulturowa na Dolnym Ślasku, Instytut Geografii i Rozwoju Regionalnego Uniwersytetu Wrocławskiego, Wrocław, s. 95-104.

ChYlÍNSKA D., KOSMAlA G., 2011, „Krajobraz po bitwie”. Niewykorzystany potencjał turystyczny pól bitew na przykładzie wojen śląskich, [w:] K. Widawski (red.), Turystyka kulturowa na Dolnym Śląsk - wybrane aspekty, t. 2, Instytut Geografii i Rozwoju Regionalnego, Uniwersytet Wrocławski, Wrocław, s. 33-69.

ClARK C., 1997, Misery and Company: Sympathy in Everyday Life, University of Chicago Press, Chicago, ss. 323.

Claval P., 1992, Champs et perspectives de la geographie culturelle, "Geographie et Cultures" 1, s. 7-38.

ClifFORD J., 1997, Routes. Travel and Translation in the Late Twentieth Century, Harvard University Press, Cambridge, London, ss. 416.

Cloke P., PAWSON E., 2008, Memorial trees and treescape memories, "Environment and Planning D: Society and Space" 26, s. 107-122. 
Coggon J., Holm S., 2007, The assisted dying bill: "Death tourism” and European law, "Ethics, Law and Society" 3, s. 233-236.

COHEN E., 2011, Zmieniające się oblicza wspótczesnej turystyki, „Folia Turistica” 25(2), s. 13-20.

Cohen-Almagor R., 2001, "Culture of Death" in the Netherlands: Dutch Perspectives, "Issues in Law and Medicine" 17(2), s. 167-179.

Cohen G., Smith R., 2010, The Racial Geography of the Federal Death Penalty, "Washington Law Review" 85(3), s. 425-492.

COSGROVE D., JACKSON P.,1987, New directions in cultural geography, "Area” 19(2), s. 95-101.

CZARNOWSKI S., 1956, Kultura, [w:] S. Czarnowski (red.), Dzieła, t. 1, Warszawa, PWN.

DANN G.M.S., 1998, The Dark Side of Tourism, Etudes et Rapports, 14, Centre International de Recherches et d'Etudes Touristiques, Aix-en-Provence, serie L, s. 1-33.

DANN G.M.S., SEATON A.V. (red.), 2001, Slavery, contested heritage and thanatourism, Haworth Hospitality Press, New York, ss. 221.

Davis A., Prentice R., 1995, Conceptualizing the Latent Visitor to Heritage Attractions, „Tourism Management” 16(7), s. 491-500.

DAVIES D.J., 2002, Death, ritual and belief, Continuum, London, ss. 263.

DAVIES D.J., PARK C. W., 2012, Emotion, Identity and Death: Mortality across Disciplines, Ashgate Publishing Company, ss. 231.

De MARCo D., WiKer B., 2004, Architects of the Culture of Death, Ignatius Press, San Francisco, ss. 410.

DELYSER D., 1999, Authenticity on the ground: Engaging the past in a California ghost town, "Annals of the Association of American Geographers" 89(4), s. 602-632.

DENNEHY R., 2006, Liberal democracy as a culture of death: why John Paul II was right, „Telos", 134, s. 31-63.

DERRIDA J., 1995, The gift of death, University of Chicago Press, ss. 115.

DOBROWOLSKI K., 1966, Studia nad życiem społecznym $i$ kultura, Wydawnictwo PAN, Zakład Narodowy im. Ossolińskich, Wrocław-Warszawa-Kraków, ss. 306.

DREWNIAK T., SzUBA B., 2007, W poszukiwaniu znaczenia przestrzeni miejskiej, [w:] T. Drewniak, B. Szuba (red.), Przestrzeń miejska, Oficyna Wydawnicza PWSZ w Nysie, Nysa, s. 7-15.

DrIVER F., 1988, Moral Geographies: Social Science and the Urban Environment in Mid-Nineteenth Century England, „Transactions of Institute of British Geographers” 13, s. 275287.

DuBISz S. (red.), 2003, Uniwersalny słownik jezyka polskiego, Wydawnictwo Naukowe PWN, Warszawa.

DunKLEY R.A., MORGAN N., WeSTWOOD S., 2007, A shot in the dark? Developing a new conceptual framework for thanatourism, "Asian Journal of Tourism and Hospitality" 1(1), s. 54-63.

DZIUBKowa J. (red.), 1996, Vanitas. Portret trumienny na tle sarmackich obyczajów pogrzebowych, Poznań.

Eberhart P., 1981, Guide to the Colorado Ghost Towns and Mining Camps, Swallow Press, ss. 496.

EDMOND C., MAK J., 2006, Terrorism and Tourism in the Asia Pacific Region: Is Travel and Tourism in a New World After 9/11?, "East-West Center Working Papers, Economics Series" 86, ss. 26.

ELIADE M., 1992, Okultyzm, czary, mody kulturalne, Oficyna Literacka, Kraków, ss. 149. 
ELIADE M., 1993, Sacrum, mit, historia, PIW, Warszawa.

EliAde M., 1996, Sacrum i profanum. O istocie religijności, Wydawnictwo KR, Warszawa.

Encyklopedia terroryzmu, Muza S.A., Wydawnictwo Bellona, Warszawa, ss. 745.

ERIKSSON P., 2010, Land for the Dead: Access to and Evolvement of Necral Land in Dar es Salaam, Tanzania, Department of Human Geography, Stockholm University, ss. 60.

FARRER D.S., 2009, Deathscapes of the Malay Martial Artist, „Shadows of the Prophet, Muslims in Global Societies Series" 2, s. 251-270.

FARRINGTON K., 1997, Historia kar i tortur. Ciemna strona wymiaru sprawiedliwości, Elipsa, Warszawa, ss. 192.

FiRTH R., 1965, Społeczności ludzkie. Wstęp do antropologii społecznej, PWN, Warszawa, ss. 249.

FOLEY M., LENNON J., 1996, JFK and a fascination with assassination, „International Journal of Heritage Studies" 2(4), s. 210-216.

Foley M., LenNON J., 1997, Dark Tourism - An Ethical Dilemma, [w:] M. Foley, J. Lennon, G. Maxwell (red.), Strategic Issues for the Hospitality, Tourism and Leisure Industries, London, s. 153-164.

FOREST B., JOHNSON J., 2002, Unravelling the threads of history: Soviet-era monuments and postSoviet national identity in Moscow, "Annals of the Association of American Geographers" 92(3), s. 524-547.

Foster L.T., EDGELl M.C.R. (red.), 1992, The geography of death: Mortality atlas of British Columbia, "Canadian Western Geographical Series” 26, s. 63-165.

FRANCAVIGLIA R.V., 1971, The cemetery as an evolving cultural landscape, "Annals Association of American Geographers" 61(3), s. 501-509.

Fuchs W., Klima R., Lautman R., RAMmstedt O., WienOld H. (red.), 1975, Lexicon zur Sociologie, t. 1-2, Reinbek, Rohwolt.

GARMAN J.C., 1994, Viewing the color line through the material culture of death, „Historical Archaeology" 28(3), s. 74-93.

GAWORECKI W., 2006, Turystyka, PWE, Warszawa, ss. 370.

GERHART K.M., 2009, The material culture of death in medieval Japan, University of Hawai'i Press.

GidDENS A., 2001, Nowoczesność i tożsamość. Ja i społeczeństwo w epoce późnej nowoczesności, Wydawnictwo Naukowe PWN, Warszawa, ss. 322.

GIDDENS A., 2010, Socjologia, Wydawnictwo Naukowe PWN, Warszawa, ss. 765.

Gold J.R., 1980, An Introduction to Behavioural Geography, Oxford University Press, London.

GolKA M., 2008, Socjologia kultury, Seria „Wykłady z Socjologii”, t. 5, Wydawnictwo Naukowe Scholar, Warszawa, ss. 359.

GolledGe L.G., BROWN L.A., WiLLIAMSON F., 1972, Behavioural approaches in Geography: an overview, "Australian Geographer" 12, s. 59-79.

GORDON B.M., 1998, Warfare and tourism. Paris in World War II, "Annals of Tourism Research" 25(3), s. 616-638.

GORER G., 1979, Pornografia śmierci, „Teksty” 45(3).

GralczYK A., LASKOWSKA M., DRZEWIECKI P. (red.), 2012, Media wobec śmierci, t. 2, Elipsa, Warszawa, ss. 328.

GRASSMAN E.J., WHITAKER A., 2007, End of life and dimensions of civil society: The church of Sweden in a new geography of death, „Mortality” 12(3), s. 261-280. 
Groote P., 2012, Deathscapes: Spaces for Death, Dying, Mourning and Remembrance, „Social \& Cultural Geography" 13(6), s. 671-672.

GRYGLEWSKI R.W., 2005, Mumifikacja ciała ludzkiego w świetle historii obyczajów i nauk medycznych, Kraków, ss. 251.

GRZEGORCZYK A., 1989, Etyka w doświadczeniu wewnętrznym, Instytut Wydawniczy PAX, Warszawa, ss. 473.

GRZESIAK H., 2011, Prezentacja Kairu pod kąem możliwości rozwoju tanatoturystyki, „Turystyka Kulturowa" 12, s. 27-42.

GuTOWSKI B., 2002, Śmierć w sztuce polskiej lat dziewięćdziesiątych, [w:] J. Kolbuszewski (red.), Problemy wspótczesnej tanatologii: medycyna, antropologia kultury, humanistyka, t. 6, Wrocławskie Towarzystwo Naukowe, Wrocław.

Hartig K.V., DunN K.M., 1998, Roadside Memorials: Interpreting New Deathscapes in Newcastle, New South Wales, „Australian Geographical Studies” 36(1), s. 5-20.

HeAthсоте G., 1986, Historical Necrogeography of Newcastle-Lake Macquarie, University of Newcastle, Department of Geography, ss. 112.

HeCKel D.E., 1972, Necrogeography: A Geographic Analysis of the Cemeteries of Coles County, Eastern Illinois University, ss. 148.

HeIDEGGER M., 1994, Bycie $i$ czas, Wydawnictwo Naukowe PWN, Warszawa, ss. 481.

HeideGger M., 2004, Byt $i$ czas, Wydawnictwo Naukowe PWN, Warszawa, ss. 570.

HENDERSON J.C., 1997, Singapore's wartime heritage attractions, "Journal of Tourism Research" 8(2), s. 39-49.

HENDERSON J.C., 2000, War as a tourist attraction: the Case of Vietnam, "International Journal of Tourism Research" 2, s. 269-280.

HowE G.M., 1968, The geography of death, „New Scientist”, 12, s. 612-14.

HOWETT C., 1977, Living landscapes for the dead, „Landscape”, 21, s. 9-17.

HUPKOVÁ M., 2008, Nekrogeografický výzkum česka: základní charakter a územní diferenciace nekrogeografických aspektů v Česku s dưrazem na jejich vztah $k$ náboženství, unpublished master's thesis, Charles University in Prague, Faculty of Science, Prague.

JACKOWSKI A., 1986, Kilka truizmów i refleksji na temat śmierci, kultury ludowej i sposobu patrzenia na jej wytwory, „PSL Konteksty” 1-2, s. 5.

JACKOWSKI A., 1991, Zarys geografii pielgrzymek, Zeszyty Naukowe UJ, „Prace Geograficzne" 85, ss. 230.

JACKOWSKI A., 2003, Święta przestrzeń świata. Podstawy geografii religii, Wydawnictwo UJ, Kraków, ss. 298.

JACKOWSKI A., 2007, Rozważania o krajobrazie sakralnym, [w:] Znaczenie badań krajobrazowych dla zrównoważonego rozwoju. Profesorowi A. Richlingowi w 70. Rocznice urodzin i 45-lecie pracy naukowej, Wydział Geografii i Studiów Regionalnych UW, Warszawa, s. 133-144.

JACKOWSKI A., BILSKA WODECKA E., SOŁJAN I., 2008, Geografia kultury, [w:] A. Jackowski, S. Liszewski, A. Richling (red.), Historia geografii polskiej, Wydawnictwo Naukowe PWN, Warszawa, s. 237-247.

JACKOWSKI A., SOŁJAN I., BILSKA-WODECKA E., 1999, Religie świata, szlaki pielgrzymkowe, [w:] Wielka encyklopedia geografii świata, t. 15, Wyd. Kurpisz, Poznań.

JAŁOWIECKI B., 1989, Przestrzeń znacząca, [w:] J. Wódz (red.), Przestrzeń znacząca. Studia socjologiczne, ŚIN, Katowice.

JAŁOWIECKI B., 1991, Znaczenie przestrzeni, „Studia Socjologiczne” 1-2, s. 51-67. 
JAŁOWIECKI B., SeKUŁA E.A., 2010, Funkcje pomnika w przestrzeni miejskiej, [w:] E. Rewers, A. Skórzyńska (red.), Sztuka - kapitat kulturowy polskich miast, Wydawnictwo Naukowe UAM, Poznań, s. 25-44.

JAN PAWEe II, 1995, Evangelium Vitae.

JANKELEVITCH V., 1993, Tajemnica śmierci i zjawisko śmierci, [w:] S. Cichowicz, J.M. Godzimirski (red.), Antropologia śmierci. Myśl francuska, Warszawa.

JARVIS J., 2009, Cemetery, Cementerio: Necrogeography at the Merrelltown Cemetery and Cementerio Guadalupe, Travis and Caldwell Counties, Vdm Verlag, ss. 144.

JAWORSKI J., 1979, Kres wędrówwi, Veritas, London, ss. 232.

JAŻDŻEWSKA I., 2010, Zastosowanie Systemów Informacji Geograficznej (GIS) w zachowaniu dziedzictwa kulturowego, [w:] B. Więcek, J. Perkowski (red.), Rola nauki w zachowaniu dziedzictwa kulturowego, Politechnika Łódzka, Łódź, s. 167-183.

JĘDRYSIAK T., VON ROHRSCHEIDT A.M., 2011, Militarna turystyka kulturowa, Polskie Wydawnictwo Ekonomiczne, Warszawa, ss. 293.

JęDRZEJCZYK D., 1997, Antropogeografia polska XIX i XX wieku, Wydział Geografii i Studiów Regionalnych, UW, Warszawa, ss. 168.

JĘDRZEJCZYK D., 2001, Wprowadzenie do geografii humanistycznej, Wydział Geografii i Studiów Regionalnych UW, Warszawa, ss. 143.

JĘDRZEJCZYK D., 2006, Status ontologiczny człowieka we współczesnej myśli geograficznej, [w:] W. Maik, K. Rembowska, A. Suliborski (red.), Człowiek w badaniach geograficznych, Podstawowe koncepcje i idee w geografii, t. 2, Wydawnictwo Uczelniane WSG, Bydgoszcz.

JĘDRZEJCZYK D., 2008, Przestrzeń i czas w perspektywie geograficznej, [w:] W. Maik, K. Rembowska, A. Suliborski, Terytorium, region, miejsce - czas i przestrzeń w geografii, Podstawowe koncepcje i idee w geografii, t. 4, Wydawnictwo Uczelniane WSG, Bydgoszcz, s. 13-39.

Joly D., 2010, The Dark Tourist. Sightseeing in the world's most unlikely holiday destinations, Simon \& Schuster, London-New York-Sydney-Toronto, ss. 277.

JuPP P.C., GiTTINGS C. (red.), 1999, Death in England: an illustrated history, Manchester University Press, ss. 282.

KABROŃSKA J., 2008, Architektura jako forma pamięci. Rola architektury w tworzeniu wspótczesnego horyzontu wartości, „Monografie”, 91, Politechnika Gdańska, Gdańsk, ss. 185.

KACZMAREK A., 2009, Śmierć. Poszukiwanie znaczenia w kontekstach kulturowych, społecznych $i$ politycznych, Teka Komisji Politologii i Stosunków Międzynarodowych PAN, 4, s. $165-179$.

KACZMAREK J., 1999, Przestrzenne zachowania człowieka w geografii i naukach społecznych, [w:] A. Lisowski (red.), Geografia na przełomie wieków - jedność i różnorodność, Wydział Geografii i Studiów Regionalnych UW, Warszawa, s. 219-228.

KACZMAREK J., 2002a, Człowiek i przestrzeń - antynomiczność badań geograficznych, [w:] H. Rogacki (red.), Możliwości i ograniczenia zastosowań metod badawczych w geografii społeczno-ekonomicznej i gospodarce przestrzennej, Bogucki Wydawnictwo Naukowe, Poznań, s. 25-34.

KACZMAREK J., 2002b, Nekropolie jako przestrzeń kultury, [w:] E. Orłowski (red.), Kultura jako przedmiot badań geograficznych. Studia teoretyczne i regionalne, Oddział Wrocławski PTG, UWr, Wrocław, s. 75-86.

KACZMAREK J., 2005, Podejście geobiograficzne w geografii społecznej. Zarys i podstawy metodyczne, Wydawnictwo UŁ, Łódź, ss. 240. 
KACZMAREK S., 2001, Rewitalizacja terenów poprzemystowych. Nowy wymiar w rozwoju miasta, Wydawnictwo UŁ, Łódź, ss. 157.

KARAUDA K., 1997, Przyzwyczajenie do śmierci - rola mediów. Wybrane przykłady, [w:] J. Kolbuszewski (red.), Problemy wspótczesnej tanatologii: medycyna, antropologia kultury, humanistyka, t. 1, Wrocławskie Towarzystwo Naukowe, Wrocław, s. 183-186.

KAZBERUK G., 2012, Czy sztuka może nas czegoś nauczyć o śmierci?, [w:] Z. Rudnicki (red.), Ars moriendi, ars vivendi, ars educandi, Wydawnictwo Naukowe UAM, Poznań, s. 399426.

KAZIMIERCZAK J., 2009, Tablice pamiatkowe i pomniki na obszarze Łódź Śródmieście jako obiekty upamiętniające osoby i wydarzenia z przeszłości Łodzi, maszynopis pracy magisterskiej, UŁ, Łódź.

KAZIMIERCZAK M., 2012, Internet i oswajanie tego, co nieuniknione. Przedstawienia śmierci w sieci WWW oraz Web 2.0 jako obrazy sztuki umierania, [w:] Z. Rudnicki (red.), Ars moriendi, ars vivendi, ars educandi, Wydawnictwo Naukowe UAM, Poznań, s. 55-84.

KeLLY M., 1998, Tourism, not terrorism: The visual politics of presenting Jordan as an international tourist destination, "Visual Anthropology” 11(3), s. 191-205.

KenZER M.S., 1985, Milieu and the "Intellectual Landscape". Carl O. Sauer's Undergraduate Heritage, "Annals of the Association of American Geographers" 75(2), s. 258-270.

Kerrigan M., 2009, Historia śmierci, Bellona, Warszawa, ss. 224.

KICIŃSKI K., KURCZEWSKI J., 1977, Poglądy etyczne młodego pokolenia Polaków, Polskie Radio i Telewizja, Warszawa, ss. 150.

KIDRON C.A., 2013, Being there together: Dark family tourism and the emotive experience of copresence in the Holocaust past, "Annals of Tourism Research" 41, s. 175-194.

KLIMA E., 2012, Przestrzeń religijna miasta, Wydawnictwo UŁ, Łódź, ss. 426.

KŁOSEK-KOZŁOWSKA D., 2002, Język przestrzeni a tożsamość kulturowa miasta, [w:] A. Koseski, A. Stawarz (red.), Tożsamość społeczno-kulturowa wspótczesnego miasta w Polsce, Warszawa-Pultusk, s. 23-32.

KŁOSKOWSKA A., 2005, Kultura masowa. Krytyka i obrona, Wydawnictwo Naukowe PWN, Warszawa, s. 486.

KŁOSKOWSKA A., 2007, Socjologia kultury, Wydawnictwo Naukowe PWN, Warszawa, ss. 348.

KNAFOU R., 1998, Tourism et Loisirs, [w:] T. De Saint Julien (red.), Atlas de France, vol. 7, Reclus - La Documentation Française.

KNIFFEN F., 1967, Necrogeography in the United States, "Geographical Review”, 57, s. 426-427.

KNIFFEN F., 1976, American cultural geography and folklife, [w:] D. Yoder (red.), American Folklife, University of Texas Press, Austin, s. 51-70.

KNOX D., 2006, The sacralised landscapes of Glencoe: from massacre to mass tourism, and back again, „International Journal of Tourism Research” 8(3), s. 185-197.

KOlBuszeWSKI J., 1994, Przestrzenie i krajobrazy, Oficyna Wydawnicza "Sudety” Oddziału Wrocławskiego PTTK, Wrocław, ss. 321.

Kolbuszewski J., 1996, Cmentarze, Seria: „A To Polska Właśnie”, Wydaw. Dolnośląskie, Wrocław, ss. 366.

KOLBUSZEWSKI J., 1998, Kilka uwag o historii śmierci: antropologiczno-kulturowe koncepcje śmierci i style umierania: kilka pytań, [w:] J. Kolbuszewski (red.), Problemy wspótczesnej tanatologii: medycyna, antropologia kultury, humanistyka, t. 2, Wrocławskie Towarzystwo Naukowe, Wrocław, s. 5-12. 
KolbusZewSKi J., 2007, Kilka wstępnych uwag o historii śmierci, [w:] J. Kolbuszewski (red.), Problemy wspótczesnej tanatologii: medycyna, antropologia kultury, humanistyka, t. 11, Wrocławskie Towarzystwo Naukowe, Wrocław, s. 7-13.

KolbusZeWSKI J., 2008, Śmierć polska, [w:] J. Kolbuszewski (red.), Problemy wspótczesnej tanatologii: medycyna, antropologia kultury, humanistyka, t. 12, Wrocławskie Towarzystwo Naukowe, Wrocław, s. 7-14.

KOMSTA A., 2013, Problem dark tourism i jego możliwości w Polsce, „Turystyka Kulturowa” 2, s. 46-65.

KONG L., 1990, Geography and religion: trends and prospects, "Progress in Human Geography" 14(3), s. 355-71.

KONG L., 1999, Cemeteries and Columbaria, Memorials and Mausoleums: Narrative and Interpretation in the Study of Deathscape in Geography, "Australian Geographical Studies" 37(1), s. 1-10.

KONG L., 2001, Mapping 'new' geographies of religion: politics and poetics in modernity, "Progress in Human Geography", 25(2), s. 211-233.

KOPCZYŃSKA-JAWORSKA B., 2002, Tożsamość społeczno-kulturowa a miasto jako przedmiot badań, [w:] A. Koseski, A. Stawarz (red.), Tożsamość społeczno-kulturowa wspótczesnego miasta $w$ Polsce, Warszawa-Pultusk, s. 9-16.

Koprowicz L., 2011, Socjologia kulturowa. Kontynuacje i poszukiwania, Wydawnictwo UJ, Kraków, ss. 182.

KoWALCZYK A., 2000, Geografia turyzmu, Wydawnictwo Naukowe PWN, Warszawa, ss. 287.

KOWALCZYK A., 2001, „Geografia różnorodności - różnorodność w geografii”, a może różnorodność geografii?, [w:] I. Łęcka (red.), Geografia różnorodności - różnorodność w geografii, Wydawnictwo WGiSR UW, Warszawa, s. 9-18.

KOWALCZYK A., 2003, Fortyfikacje, pola bitew, cmentarze wojenne... jako przedmiot zainteresowania geografii turyzmu, [w:] G. Białuński (red.), Fortyfikacje jako atrakcje turystyczne, Prywatna Wyższa Szkoła Zawodowa w Giżycku - Towarzystwo Miłośników Twierdzy Boyen w Giżycku, s. 5-13.

KOWALCZYK A., 2008, Wspótczesna turystyka kulturowa - między tradycją a nowoczesnościa, [w:] A. Kowalczyk (red.), Turystyka kulturowa. Spojrzenie geograficzne, „Geografia Turyzmu" 1, UW, Warszawa, s. 9-58.

KOWALCZYK A., 2009a, Proces przekształcania zasobów kulturowych w atrakcje turystyczne (na przyktadzie zagospodarowania turystycznego pól bitewnych), [w:] A. Stasiak (red.), Kultura i turystyka. Razem, ale jak?, Wydawnictwo WSTiH w Łodzi, Łódź, s. 33-46.

KOWALCZYK A., 2009b, Turystyka historyczno-militarna, [w:] K. Buczkowska, A. Mikos von Rohrscheidt (red.), Wspótczesne formy turystyki kulturowej, t. 1, AWF im. E. Piaseckiego w Poznaniu, Poznań, s. 286-312.

KOWALCZYK A., 2011, "Geograficzne” aspekty przestrzeni turystycznej (nowe spojrzenia na koncepcje przestrzeni turystycznej), [w:] M. Durydiwka, K. Duda-Gromada (red.), Przestrzeń turystyczna: czynniki, różnorodność, zmiany, Wydawnictwo WGiSR, Warszawa, s. 29-38.

KRAJEWSKI M., 2001, Kultura okrucieństwa. Przemoc jako towar, [w:] M. Ziółkowski (red.), Ludzie teraźniejsi a cywilizacja przełomu tysiącleci, Wydawnictwo Fundacji Humaniora, Poznań, s. 199-208.

KRAJEWSKI M., 2005, Kultury kultury popularnej, „Seria Socjologia” 34, Wydawnictwo Naukowe UAM, Poznań, ss. 337. 
KRAMER K.P., 2006, Śmierć w różnych religiach świata, Seria: „Mała Biblioteka Religii”, Wydawnictwo WAM, Kraków, ss. 332.

KROEBER A.L., 1973, Istota kultury, PWN, Warszawa, ss. 697.

KRUCZEK Z., 1997, Metodyka krajoznawstwa, „Wydawnictwo Skryptowe” 37, AWF Kraków, ss. 172.

KRUCZEK Z., KUREK A, NOWACKI M., 2007, Krajoznawstwo. Zarys teorii i metodyki, Proksenia, Kraków, ss. 249.

KUREK W. (red.), 2008, Turystyka, Wydawnictwo Naukowe PWN, ss. 430.

KURYLUK E., 2002, Od śmierci będącej sztuką do sztuki śmierci. Refleksje o sztuce i śmierci, [w:] K. Grodziska, J. Purchla (red.), Śmierć, przestrzeń, czas, tożsamość w Europie Środkowej około 1900, Kraków, s. 73-85.

KWASIK K., JAROSZYŃSKI J., ŁĘCICKI G. (red.), 2012, Media wobec śmierci, t. 1, Elipsa, Warszawa, ss. 367.

KWIATKOWSKI B., 2005, Mumie. Wtadcy, święci, tyrani, Wydawnictwo Iskry, Warszawa, ss. 395.

LATOSIŃSKA J., 2006, Przestrzeń turystyczna - jedno pojęcie, dwa znaczenia. Rozważania na temat indywidualnej przestrzeni turystycznej, „Turyzm” 16(2), s. 93-98.

LEIPER N., 1979, The Framework of Tourism, „Annals of Tourism Research" 6(4), s. 390-407.

LENNON J., FOLEY M., 1999, Interpretation of the Unimaginable: The US Holocaust Memorial Museum, Washington D.C. and "Dark Tourism", "Journal of Travel Research" 38, s. 4650.

LENNON J., FOLEY M., 2000, Dark tourism: The attraction of death and disaster, Continuum, London, ss. 184.

LESZCZYCKI S., 1937, Zagadnienia geografii turyzmu, „Komunikaty Studium Turyzmu UJ” 2.

LEWANDOWSKI R., 2004, Śmierć w nowych dekoracjach, „Opcje” 1-2, s. 176-182.

LEWIS C., 2008, Deconstructing Grief Tourism, Catherine, „International Journal of the Humanities" 6(6), s. 165-169.

Ley D., SAmuels M. (red.), 1978, Humanistic Geography: Prospects and Problems, Maaroufa Press, Chicago.

LIJEWSKI T., MikUŁOWSKI B., WYRZYKOWSKI J., 2002, Geografia turystyki Polski, PWE, Warszawa.

LinTon R., 1975, Dyfuzja, [w:] W. Derczyński, A. Jasińska-Kania, J. Szacki (red.), Elementy teorii socjologicznych. Materiały do dziejów wspótczesnej socjologii, PWN, Warszawa.

LIPNIACKI W., 1985, Elementy teorii krajoznawstwa. Krajoznawstwo jako działalność poznawcza, t. 1, PTTK, Szczecin, ss. 300.

LisLE D., 2004, Gazing at Ground Zero: tourism, voyeurism and spectacle, "Journal for Cultural Research" 8(1), s. 3-21.

LiSLE D., 2013, Frontline leisure: Securitizing tourism in the War on Terror, "Security Dialogue” 44(2), s. 127-146.

LISOWSKI A., 2001, Różnorodność w geografii - nadzieje i obawy, [w:] I. Łęcka (red.), Geografia różnorodności - różnorodność w geografii, Wydział Geografii i Studiów Regionalnych UW, Warszawa, s. 19-25.

LISOWSKI A., 2003, Koncepcje przestrzeni w geografii człowieka, Wydział Geografii i Studiów Regionalnych UW, Warszawa, ss. 198.

LISOWSKI A., 2005, Geografia jako nauka chorologiczna, [w:] W. Maik, K. Rembowska, A. Suliborski (red.), Podstawowe idee i koncepcje w geografii, t. 1, Geografia jako nauka o prze- 
strzeni, środowisku i krajobrazie, Zakład Geografii Społecznej i Turystyki UMK, Zakład Badań Społecznych i Regionalnych UŁ, ŁTN, Łódź, s. 25-49.

LiSZEWSKI S., 1981, Badania w zakresie geografii turyzmu, Zeszyty Naukowe UJ, „Prace Geograficzne" 54, s. 41-50.

LISZEWSKI S., 1994, Perspektywy badań naukowych w zakresie turystyki w Polsce w najbliższym dziesięcioleciu, „Problemy Turystyki” XVII, $3 / 4$ (65/66), s. 105-111.

LISZEWSKI S., 1995, Przestrzeń turystyczna, „Turyzm” 5(2), s. 87-101.

LISZEWSKI S., 1999, Przestrzeń turystyczna miasta (przykład Łodzi), „Turyzm” 9(1), s. 51-70.

LisZeWSKI S., 2005, Przestrzeń turystyczna w ujęciu podmiotowym. Przyczynek do dyskusji o przestrzeni w geografii, [w:] W. Maik, K. Rembowska, A. Suliborski (red.), Podstawowe idee i koncepcje w geografii, t. 1, Geografia jako Nauka o przestrzeni, środowisku i krajobrazie, Zakład Geografii Społecznej i Turystyki UMK, Zakład Badań Społecznych i Regionalnych UŁ, ŁTN, Łódź, s. 50-60.

LISZEWSKI S., 2006, Przestrzenie turystyki i ich transformacje we wspótczesnym świecie, „Turyzm" 16(2), s. 7-19.

LisZEWSKI S., 2010, Miejska przestrzeń eksploracji turystycznej. Przykład Łodzi, „Turyzm” 19(12), s. 59-66.

LLEWELLYN N., 1991, The art of death: visual culture in the English death ritual c. 1500-c. 1800, Reaktion Books, ss. 160.

LLOYD D.W., 1998, Battlefield Tourism: Pilgrimage and the commemoration of the Great War in Britain, Australia and Canada 1919-1939, Oxford, New York, Berg, ss. 251.

LORENS P., 2006, Tematyzacja przestrzeni publicznej miasta, Wydawnictwo PG, Gdańsk.

Lunt N., CARRERA P., 2010, Medical tourism: assessing the evidence on treatment abroad, "Maturitas" 66(1), s. 27-32.

LUTY-MiCHALAK M., 2010, Więź międzypokoleniowa w starzejącym się społeczeństwie polskim. Czy jesteśmy świadkami prefiguratywności kulturowego przekazu międzypokoleniowego?, [w:] E. Rekłajtis, R. Wiśniewski, J. Zdanowski (red.), Jedność i różnorodność. Kultura vs kultury, Oficyna Wydawnicza ASPRA-JR, Warszawa, s. 417-430.

ŁABUSZEWSKI T. (red.), 2012, Śladami zbrodni. Przewodnik po miejscach represji komunistycznych lat 1944-1956, IPN, Warszawa, ss. 632.

MACCANNELl D., 2002, Turysta, nowa teoria klasy próżniaczej, Muza S.A., Warszawa, ss. 352.

MACHINEK M., 2001, Oblicza kultury śmierci, „Posłaniec Warmiński” 20(4), s. 4-8.

MADDRELL A., SIDAWAY J.D., 2010, Introduction: bringing a spatial lens to death, dying, mourning and remembrance, [w:] A. Maddrell, J.D. Sidaway (red.), Deathscapes. Spaces for death, dying, mourning and remembering, Ashgate, Farnham, s. 1-16.

MARGUL T., 1986, Religia a przestrzeń i krajobraz, „Skrypty Uczelniane” 526, Wydawnictwo UJ, Kraków.

MARIAŃSKI J., 2001, Kryzys moralny czy transformacja wartości? Studium socjologiczne, Towarzystwo Naukowe KUL, Lublin, ss. 496.

MARTIN D., 2010, Medical travel and the sale of human biological materials: Suggestions for ehical policy development, "Global Social Policy” 10(3), s. 377-395.

MATERO F.G., PETERS J., 2003, Survey methodology for the preservation of historic burial grounds and cemeteries, "APT Bulletin” 34(2/3), s. 37-45. 
MATYKOWSKI R., DuRA M., 2010, Tanatotopografia pamięci w przestrzeni publicznej Poznania, [w:] J. Słodczyk, A. Dembicka-Niemiec (red.), 2010, Funkcje miast jako czynnik kształtowania przestrzeni miejskiej, „Studia Miejskie” 2, Wydawnictwo UO, Opole, s. 87-94.

MAZURKIEWICZ L., 1994, Geografia społeczno-ekonomiczna czy geografia człowieka, „Czasopismo Geograficzne" 65(2), s. 179-188.

MAZURKIEWICZ L., 2007, Model przestrzennego zachowania turystów, „Przegląd Geograficzny" 79(1), s. 99-113.

MEAD M., 1978, Kultura i tożsamość. Studium dystansu międzypokoleniowego, PWN, Warszawa, ss. 147.

METELSKI A., 2001, Okiełznany lęk. O przewartościowaniu znaczenia śmierci w mediach i reklamie, [w:] J. Kolbuszewski (red.), Problemy wspótczesnej tanatologii: medycyna, antropologia kultury, humanistyka, t. 5, Wrocławskie Towarzystwo Naukowe, Wrocław, s. 439-445.

MEYER B., 2004, Turystyka jako ekonomiczny czynnik kształtowania przestrzeni, „Rozprawy i Studia" (DCXIX) 545, USz, Szczecin, ss. 436.

MeYer R.E., 1993, Ethnicity and the American cemetery, Popular Press, ss. 239.

MichalSKA-Dudek I., PRZEOREK-SMYKa R., 2012, „Turystyka Smoleńska” przykładem produktu tanatoturystycznego biur podróży, „Popyt turystyczny. Konsumpcja - segmentacja - rynki”, Zeszyty Naukowe 699, „Ekonomiczne Problemy Usług” 84, Wydawnictwo Naukowe USz, Szczecin, s. 471-483.

Międzynarodowy słownik turystyczny, 1961, SiT, Warszawa.

MiLEs W.F.S., 2002, Auschwitz: Museum Interpretation and darker tourism, „Annals of Tourism Research" 29(4), s. 1175-1178.

Miossec J.M., 1977, Un model de l'espace touristique, „L'Espace Gẻographique” 6(1), s. 41-48.

Mitford J., 1963, The American Way of Death, Simon and Schuster, New York, ss. 333.

Mitford J., 2000, The American Way of Death Revisited, Vintage Books, New York, ss. 320.

MoISAN-JABŁOŃSKA K., 2001, Mors, Iudicum, Infernus, Coelum et Purgatorium, czyli rzecz o sprawach ostatecznych, [w:] D. Galas (red.), Śmierć w kulturze dawnej Polski: od średniowiecza do końca XVIII wieku, Warszawa.

MurRay M., 1962, The geography of death in England and Wales, "Annals of the Association of American Geographers" 52(2), s. 130-149.

MurRAY M.A., 1967, The geography of death in the United States and the United Kingdom, "Annals of the Association of American Geographers" 57(2), s. 301-314.

Muszel M., 2007, Tanatoturystyka - mroczna strona turystyki, „Kultura i Społeczeństwo” (51)1, s. 151-167.

Myga-PiąTeK U. (red.), 2001, Krajobraz kulturowy. Idee, problemy, wyzwania, Wydział Nauk o Ziemi, Uniwersytet Śląski, Oddział Katowicki PTG, Sosnowiec.

MYGA-PIĄTEK U., 2005, Krajobraz Kulturowy w badaniach geograficznych, [w:] U. Myga-Piątek (red.), Krajobraz kulturowy. Aspekty teoretyczne i metodologiczne, Prace Komisji Krajobrazu Kulturowego PTG 4, s. 40-51.

NAKAGAWA T., 1987, The Cemetery as a Cultural Manifestation: Louisiana Necrogeography, doctoral dissertation, Baton Rouge, The Louisiana State University and Agricultural Mechanical College.

NAVRATIL J., Picha K., 2012, Motivace k ucasti na aktivitach temneho cestovniho ruchu, "Czech Jurnal of Tourism" 1(2), s. 156-167. 
Nieroba E., CZERner A., SZCZEPAŃSKI M.S., 2010, Flirty tradycji z popkulturą. Dziedzictwo kulturowe w późnej nowoczesności, Wydawnictwo Naukowe Scholar, Warszawa, ss. 298.

NiEZGODA A., 2006, Obszar recepcji turystycznej w warunkach rozwoju zrównoważonego, Wydawnictwo AE w Poznaniu, Poznań, ss. 299.

Nola DI A.M., 2006, Tryumf śmierci. Antropologia żałoby, Universitas, Kraków, ss. 385.

NOWACKI M., 2000, Atrakcje turystyczne, dziedzictwo i jego interpretacja - jako produkt turystyczny, "Turyzm" 10(1), s. 111-122.

NOWACKI M., 2012, Atrakcje turystyczne: koncepcje, stan, determinanty zadowolenia osób zwiedzających, AWF, Poznań, ss. 381.

NowICKI A., 1985, Przestrzeń spotkań. Prolegomena do inkontrologicznej filozofii przestrzeni, [w:] A. Nowicki (red.), Filozofia przestrzeni, UMCS, MIFS, Lublin, s. 7-28.

NoYs B., 2005, The culture of death, Berg Publishers.

Oppermmann M., 1993, Tourism Space in Developing Countries, „Annals of Tourism Research" 20(3), s. 535-556.

ORŁOWSKA E. (red.), 2002, Kultura jako przedmiot badań geograficznych, t. 1, Wydawnictwo Oddziału Wrocławskiego PTG, UWr, Wrocław, ss. 228.

ORŁOWSKA E. (red.), 2004, Kulturowy aspekt badań geograficznych, t. 4, Studia teoretyczne i regionalne, Wydawnictwo Oddziału Wrocławskiego PTG, UWr, Wrocław, ss. 245.

ORŁOWSKA E., 2005, Kulturowy aspekt badań geograficznych, [w:] U. Myga-Piątek (red.), Krajobraz kulturowy. Aspekty teoretyczne i metodologiczne, „Prace Komisji Krajobrazu Kulturowego PTG" 4, s. 55-64.

OssowSKA M., 1969, Socjologia moralności: zarys zagadnień, PWN, Warszawa, ss. 395.

OstASZEWSKA K., 2002, Geografia krajobrazu. Wybrane zagadnienia metodologiczne, Wydawnictwo Naukowe PWN, Warszawa, ss. 277.

OstrowsKA A. 1991, Śmierć w doświadczeniu jednostki i społeczeństwa, IFiS PAN, Warszawa, ss. 228.

Оток S., 1986, Geografia i kultura, „Przegląd Zagranicznej Literatury Geograficznej” 1-2, s. 5-8.

PAKES F., 2003, Tolerance and pragmatism in the Netherlands: Euthanasia, coffeeshops and prostitution in the 'purple years', 1994-2002 "International Journal of Police Science and Management" 5(4), s. 217-228.

PASCAl B., 1996, Myśli, Warszawa, ss. 120.

PIEŃKOS A., 1996, Konwencja obrazowania śmierci w sztuce XIX w. Między forma a tabu, „Rocznik Historii Sztuki" XXII.

PieńKOS A., 2000, Okropności sztuki: nowoczesne obrazy rzeczy ostatecznych, Gdańsk, ss. 337.

PitTE J.R., 2004, A short cultural geography of death and the dead, "GeoJournal" 60(4), s. 345351.

PODEMSKI K., 2004, Socjologia podróży, Wydawnictwo Naukowe UAM, Poznań, ss. 368.

PRINKE R.T., 2009, Turystyka genealogiczna - niedostrzegana nisza, „Turystyka Kulturowa” 6, s. 4-12.

PRZECŁAWSKI K., 1979, Socjologiczne problemy turystyki, Instytut Wydawniczy CRZZ, Warszawa, ss. 157.

PRZECŁAWSKI K., 1987, Turystyka i jej rola we wspótczesnym świecie, „Problemy Turystyki” 3(37).

PRZECŁAWSKI K., 1996, Człowiek a turystyka. Zarys socjologii turystyki, Albis, Kraków, ss. 160. 
PRZECŁAWSKI K., 2000, Polska jako teren przenikania kultur - rola turystyki, „Ziemia”, V Kongres Krajoznawstwa Polskiego, s. 179-184.

PULIANOWA M.Z., KŁODNICKI Z., 2005, O komplementarności dyscyplin geografii i etnologii, [w:] U. Myga-Piątek (red.), Krajobraz kulturowy. Aspekty teoretyczne i metodologiczne, Prace Komisji Krajobrazu Kulturowego PTG 4, s. 91-104.

RAGON M., 1983, The Space of Death: A Study of Funerary Architecture, Decoration and Urbanism, University Press of Virginia, ss. 328.

RAWECKI M. (oprac.), 2005, Ekspertyza stanu zachowania i warunków ochrony miejsc i obiektów kompleksu Auschwitz-Birkenau. Analiza warunków opracowania i wdrożenia planu zarządzania, Gliwice.

REMBOWSKA K., 2002a, Podejście kulturowe - szansa na integracje geografii człowieka, "Acta Universitatis Lodziensis, Folia Geographica Socio-Oeconomica" 4, s. 3-9.

REMBOWSKA K., 2002b, Kultura w tradycji i we wspótczesnych nurtach badań geograficznych, Wydawnictwo UŁ, ss. 197.

REMBOWSKA K., 2006, Człowiek w geograficznych obrazach świata. Próba rekonstrukcji, [w:] W. Maik, K. Rembowska, A. Suliborski (red.), Człowiek w badaniach geograficznych, t. 2, Podstawowe idee $i$ koncepcje w geografii, Wydawnictwo Uczelniane WSG, Bydgoszcz.

RICE A., 2009, Museums, memorials and plantation houses in the Black Atlantic: Slavery and the development of dark tourism, [w:] R. Sharpley, P.R. Stone (red.), The darker side of travel: The theory and practice of dark tourism, Aspect of Tourism Series, Channel View Publications, Bristol, s. 224-246.

Richling A., 2008, Geografia krajobrazu, [w:] A. Jackowski, S. Liszewski, A. Richling (red.), Historia geografii polskiej, Wydawnictwo Naukowe PWN, Warszawa, s. 134-146.

ROJEK C., 1993, Ways of escape: Modern transformations in leisure and travel, MacMillan, London.

ROJEK C., 1997, Indexing, dragging and the social construction of tourist sights, [w:] C. Rojek, J. Urryed (red.), Touring cultures, Routledge, London, s. 52-73.

ROMANISZYN K., 2010, O ujednoliceniu i o swoistości kultur, [w:] E. Rekłajtis, R. Wiśniewski, J. Zdanowski (red.), Jedność i różnorodność. Kultura vs kultury, Oficyna Wydawnicza ASPRA-JR, Warszawa, s. 35-45.

SAFYAN A.R., 2011, A Call for International Regulation of the Thriving "Industry" of Death Tourism, "Loyola of Los Angeles International and Comparative Law Review” 33(2), s. 287-319.

SAREŁo Z., 1998, Postmodernizm w pigutce, Pallottinum, Poznań, ss. 36.

SAUER C., 1986, Geografia kultury, [w:] P.L. Wagner, M.W. Mikesell (red.), Readings in cultural geography, The University of Chicago Press, Chicago, s. 30-34, „Przegląd Zagranicznej Literatury Geograficznej" 1-2, s. 23-29.

Schantz M.S., 2008, Awaiting the Heavenly Country: The Civil War and America's Culture of Death, Cornell University Press, ss. 245.

SCHELER M., 1994, Cierpienie, śmierć, dalsze życie. Pisma wybrane, Wydawnictwo Naukowe PWN, Warszawa, ss. 135.

SCHERER G., 2008, Filozofia śmierci. Od Anaksymandra do Adorno, Wydawnictwo WAM, Kraków, ss. 203.

SCHUltz R., 1978, The psychology of death, dying nad bereavement, Addison-Wesley, London, ss. 197. 
SEATON A.V., 1996, Guided by the dark: From thanatopsis to thanatourism, „International Journal of Heritage Studies" 2(4), s. 234-244.

SEATON A.V., 1999, War and thanatourism: Waterloo 1815-1914, "Annals of Tourism Researche" 26(1), s. 130-158.

SEATON A.V., 2002a, Another weekend away looking for dead bodies: Battlefield tourism on the Somme and in Flanders, "Tourism Recreation Research" 25(3), s. 63-78.

SEATON A.V., 2002b, Thanatourism's final frontiers? Visits to cemeteries, churchyards and funerary sites as sacred and secular pilgrimage, "Tourism Recreation Research" 27(2), s. 73-82.

SeAton A.V., 2009, Purposeful otherness: Approaches to the management of thanatourism, [w:] R. Sharpley, P.R. Stone (red.), The darker side of travel: The theory and practice of dark tourism, Aspect of Tourism Series, Channel View Publications, Bristol, s. 75-108.

SEATON A.V., 2010, Thanatourism and its discontents: An appraisal of a decade's work with some future issues and directions, [w:] T. Jamal, M. Robinson (red.), The sage handbook of tourism studies, Sage Publications, London, s. 521-542.

SEATON A.V., LENNON J., 2004, Moral panics, ulterior motives, and alterior desires: Thanatourism in the early 21st century, [w:] T.V. Sing (red.), New Horizons in Tourism: Strange Experiences and Stranger Practices, CABI Publishing, Wallingford, s. 63-83.

SHARPLEY R., 2005, Travels to the edge of darkness: Towards a typology of dark tourism, [w:] C. Ryan, S. Page, M. Aicken (red.), Taking Tourism to the Limits: Issues, Concepts and Managerial Perspectives, Elsevier, London, s. 215-226.

SHARPLEY R., 2009, Dark tourism and political ideology: Towards a governance model, [w:] R. Sharpley, P.R. Stone (red.), The darker side of travel: The theory and practice of dark tourism, Aspect of Tourism Series, Channel View Publications, Bristol, s. 145-163.

SHARPLEY R., 2012, Towards an understanding of 'genocide tourism': An analysis of visitors' accounts of their experience of recent genocide sites, [w:] R. Sharpley, P.R. Stone (red.), Contemporary Tourist Experience: Concepts and Consequences, Routledge, Abington, Oxon, s. 95-109.

SHARPley R., STONE P.R., 2009, Representing the Macabre: Interpretation, kitschification and authenticity, [w:] R. Sharpley, P.R. Stone (red.), The darker side of travel: The theory and practice of dark tourism, Aspect of Tourism Series, Channel View Publications, Bristol, s. 109-128.

Sharpley R., StOne P.R. (red.), 2009, The Darker Side of Travel: The Theory and Practice of Dark Tourism, „Aspects of Tourism Series”, Channel View Publications, Bristol, ss. 275.

Simmel G., 2006, Most i drzwi. Wybór esejów, Oficyna Naukowa, Warszawa.

SLADE P., 2003, Gallipoli Thanatourism: The Meaning of ANZAC, "Annals of Tourism Research", 30, s. 779-794.

SMART B., 1998, Postmodernizm, Zysk i S-ka Wydawnictwo, Poznań, ss. 213.

SмIтH V., 1996, War and its tourist attractions, [w:] A. Pizam, Y. Mansfield (red.), Tourism, crime and international security issues, Wiley, Chichester, s. 247-264.

SMith V., 1998, War and tourism: an American ethnography, "Annals of Tourism Research" 25(1), s. 202-207.

SMITH W.J., 2002, The culture of death: The assault on medical ethics in America, Encounter Books, ss. 256. 
SMOLEŃSKA I.E., 2012, Opuszczone miasta jako destynacje w turystyce kulturowej - analiza przykładów, „Turystyka Kulturowa” 12, s. 5-12.

SOŁJAN I., 2012, Sanktuaria i ich rola w organizacji przestrzeni miast na przykładzie największych europejskich ośrodków katolickich, Instytut Geografii i Gospodarki Przestrzennej UJ, Kraków, ss. 364.

SOPHER D., 1967, Geography of Religions, Englewood Cliffs, NJ, Prentice-Hall, ss. 128.

SRINIVAS R.V., 2009, Exploring the Potential for American Death Tourism, "Michigan State University College of Law Journal of Medicine and Law" 13(1), s. 92-123.

STASIAK A., TANAŚ S., 2005, Przestrzeń sepulkralna w turystyce, "Turystyka i Hotelarstwo" 8, s. 9-42.

STONE P.R., 2005, Consuming Dark Tourism: a call for research, „eReview of Tourism Research" 3(5), s. 109-117.

STONE P.R., 2006, A dark tourism spectrum: Towards a typology of death and macabre related tourist sites, attractions and exhibitions, "Tourism. An Interdisciplinary International Journal" 54(2), s. 145-160.

STONE P.R., 2009a, Dark Tourism: Morality and New Moral Spaces, [w:] R. Sharpley, P.R. Stone (red.), The darker side of travel: The theory and practice of dark tourism, Aspect of Tourism Series, Channel View Publications, Bristol, s. 56-72.

STONE P.R., 2009b, "It's Bloody Guide" - Fun, Fear and a Lighter Side of Dark Tourism at the Dungeon Visitor Attractions, [w:] R. Sharpley, P.R. Stone (red.), The darker side of travel: The theory and practice of dark tourism, Aspect of Tourism Series, Channel View Publications, Bristol, s. 167-185.

STONE P.R., 2010, Death, Dying and Dark Tourism in Contemporary Society: A Theoretical and Empirical Analysis, Doctoral Thesis, University of Central Lancashire, Preston.

STONE P.R., 2011, Dark Tourism: towards a new post-disciplinary research agenda, "International Journal of Tourism Anthropology" 1(3/4), s. 318-332.

STONE P.R., 2012, Dark Tourism and Significant other Death: Towards a model of mortality mediation, "Annals of Tourism Research" 39(3), s. 1565-1587.

StONE P.R., SHARPLEY R., 2008, Consuming dark tourism: A thanatological perspective, "Annals of Tourism Research" 35(2), s. 574-595.

STRANGE C., KeMPA M., 2003, Shades of dark tourism: Alcatraz and Robben Island, „Annals of Tourism Research" 30 (2), s. 386-405.

STRYKER S., 2004, Integrating emotion into identity theory " Advances in Group Processes" 21, s. 1-23.

STRZEMIENIECKI R., 1994, Powrót bombardierów, „Wprost” 11/09, s. 51.

SULIBORSKI A., 2005, Nekropolie jako miejsce w przestrzeni społeczno-kulturowej Łodzi. Ranga i specyfika ich znaczeń społecznych, [w:] B. Domański, S. Skiba (red.), Geografia i sacrum, t. 2, Instytut Geografii i Gospodarki Przestrzennej UJ, Kraków, s. 441-454.

SzAbat M., 2012, Moja i Twoja śmierć. Na podstawie Bycia i czasu Martina Heideggera i pism Emmanuela Levinasa, [w:] Z. Rudnicki (red.), Ars moriendi, ars vivendi, ars educandi, Wydawnictwo Naukowe UAM, Poznań, s. 25-36.

SzACKI J., 2002, Historia myśli socjologicznej, Wydawnictwo Naukowe PWN, Warszawa, ss. 1076.

SZCZEPAŃSKI J., 1970, Elementarne pojęcia socjologiczne, Warszawa, ss. 239. 
SZCZEPAŃSKI M.S., 1990, Społeczne wytwarzanie przestrzeni miejskich i generowanie znaczeń, [w:] J. Wódz (red.), Przestrzeń znacząca. Studia socjologiczne, ŚIN, Katowice, s. 154-179.

SZEWCZYK-KOWALCZYK J., 2012, Śmierć w polskiej kulturze tradycyjnej, [w:] Z. Rudnicki (red.), Ars moriendi, ars vivendi, ars educandi, Wydawnictwo Naukowe UAM, Poznań, s. 85-104.

SzOlginia W., 1982, Ilustrowana Encyklopedia dla Wszystkich. Architektura i budownictwo, Wydawnictwo Naukowo-Techniczne, Warszawa.

SZYMCZAK M. (red.), 1982, Stownik języka polskiego, PWN, Warszawa.

TANAŚS., 2004, Cmentarz jako obiekt zainteresowania geografii turyzmu, „Turyzm” 14(2), s. 7187.

TANAŚ S., 2006a, Tanatoturystyka - kontrowersyjne oblicze turystyki kulturowej, „Peregrinus Cracoviensis" 17, s. 85-100.

TANAŚS., 2006b, Znaczenie przestrzeni śmierci w turystyce kulturowej, „Turyzm” 16(2), s. 145151.

TANAŚ S., 2007, Przestrzeń sepulkralna jako przestrzeń zainteresowań turysty, [w:] J. Kolbuszewski (red.), Problemy wspótczesnej tanatologii: medycyna, antropologia kultury, humanistyka, t. 11, Wrocławskie Towarzystwo Naukowe, Wrocław, s. 247-252.

TANAŚS., 2008a, Percepcja śmierci w turystyce kulturowej, „Turyzm” 18(1), s. 51-63.

TANAŚ S., 2008b, Przestrzeń turystyczna cmentarzy. Wstęp do tanatoturystyki, Wydawnictwo UŁ, Łódź, ss. 215.

TANAŚS., 2011a, Uwarunkowania wykorzystania przestrzeni śmierci na potrzeby turystyki kulturowej, "Turystyka i Rekreacja - Studia i Prace” 7, s. 181-189.

TANAŚ S., 2011b, Znaczenie pamięci w przestrzeni turystycznej miasta, [w:] B. Włodarczyk (red.), Turystyka. Księga jubileuszowa w 70. rocznicę urodzin Profesora Stanisława Liszewskiego, Wydawnictwo UŁ, Łódź, s. 121-133.

TANAŚ S., 2012, Edukacyjne i wychowawcze aspekty tanatoturystyki, [w:] Z. Rudnicki (red.), Ars moriendi, ars vivendi, ars educandi, Wydawnictwo Naukowe UAM, Poznań, s. 427442.

TAZBIR J., 1999, Okrucieństwo w nowoczesnej Europie, Sic!, Warszawa, ss. 350.

TEATHER E.K., 2001, The case of the disorderly graves: contemporary deathscapes in Guangzhou, "Social and Cultural Geography" 2(2), s. 185-202.

TEATHER E.K., RII H.U., KIM E.H., 2001, Seoul's deathscapes: incorporating tradition into modern time-space, „Environment and Planning A” 33(8), s. 1489-1506.

TESTER K., 1997, Moral Culture, Sage Publications Ltd.

The Oxford English Dictonary, 1991, vol. XVII, Clarendon Press, Oxford.

THOMAS L.V., 2001, Trup, Ethos, Warszawa, ss. 220.

Thrift N., 1983, Wstęp do geografii czasu, [w:] G. Węcławowicz, Geografia czasu, „Przegląd Zagranicznej Literatury Geograficznej" t. 1.

TREMLETT P.F., 2007, Death-scapes in Taipei and Manila: a postmodern necrography, "Taiwan in Comparative Perpsective" 1, s. 23-36.

TRZUPKA J., 2001, Wstęp, [w:] J. Trzupka (red.), Oblicza śmierci we współczesnej sztuce polskiej, BWA, Katowice.

TUAN Y.F., 1978, Sign and Methapor, "Annals of the Association of American Geographers" 68(3), s. 363-372.

TuAN Y.F., 1987, Przestrzeń i miejsce, PIW, Warszawa, ss. 251. 
TURNER J.H., STETS J.E., 2009, Socjologia emocji, Wydawnictwo Naukowe PWN, Warszawa, ss. 363.

UNWTO Tourism Highlights, 2012.

UNWTO World Tourism Barometr, 2013, vol. 11.

URRY J., 2007, Spojrzenie turysty, Wydawnictwo Naukowe PWN, Warszawa, ss. 279.

VARGAS J.C., AMPARO A.J., 2010, Geographies of death: an intersectional analysis of police lethality and the racialized regimes of citizenship in São Paulo, "Ethnic and Racial Studies" 33(4), s. 611-636.

VERDERY K., 1999, The political lives of dead bodies, Columbia University Press, New York, Ss. 208.

Vovelle M., 2004, Śmierć w cywilizacji Zachodu, Słowo/Obraz/Terytoria, Gdańsk, ss. 670.

WALLIS A., 1990, Socjologia przestrzeni, Niezależna Oficyna Wydawnicza, Warszawa, ss. 261.

WALMSLEY D.J., LeWIS G.J., 1997, Geografia człowieka. Podejście behawioralne, Wydawnictwo Naukowe PWN, Warszawa, ss. 302.

WARNER W., 1959, The Living and the Dead, Yale University Press, New Haven.

WARSZYŃSKA J., 1999, Główne problemy badawcze geografii turyzmu, „Turyzm” 9(1), s. 37-50.

WARSZYŃSKA J., JACKOWSKI A., 1978, Podstawy geografii turyzmu, PWN, Warszawa, ss. 333.

WARTECKA-WAŻYŃSKA A., 2010, Cmentarze nowa wartość kulturowa i przykład przestrzeni turystyczno-rekreacyjnej w warunkach globalizacji, "Zeszyty Naukowe Wyższej Szkoły Handlu i Usług w Poznaniu" 19, s. 319-328.

WARYLEWSKI J., 2007, Kara. Podstawy filozoficzne i historyczne, Wydawnictwo UG, Gdańsk, ss. 314.

WARZESZEK S., 1997, U źródeł wspótczesnej kultury śmierci, „Warszawskie Studia Teologiczne" 10, s. 413-426.

WieCZORKIEWICZ A.M., 2008, Apetyt turysty: o doświadczaniu świata w podróży, „Horyzonty Nowoczesności" 66, Universitas, Kraków, s. 383.

WIĘCEK A., 2005, Wybrane aspekty przestrzeni sepulkralnej Krakowa, „Peregrinus Cracoviensis" 16, s. 101-114.

Williams P., 2007, Memorial Museums: The Global Rush to Commemorate Atrocities, Berg Publishers, ss. 236.

WINIARSKI R., ZDEBSKI J., 2008, Psychologia turystyki, Wydawnictwa Akademickie i Profesjonalne, Warszawa, ss. 152.

WINTER C., 2011, Battlefield visitor motivations: explorations in the Great War town of Ieper, Belgium, „International Journal of Tourism Research” 13(2), s. 164-176.

WŁodarCZYK B., 2006, Przestrzeń turystyczna - cykliczność, aktorzy, determinanty rozwoju, "Turyzm" 16(2), s. 41-64.

WŁodARCZYK B., 2009, Przestrzeń turystyczna. Istota, koncepcje, determinanty rozwoju, Wydawnictwo UŁ, Łódź, ss. 268.

WOJCIECHOWSKI K., 1986, Problemy percepcji i oceny estetycznej krajobrazu, „Rozprawy UMCS” t. 27.

Wójсік M., 2008, Miejsce człowieka na Ziemi - refleksje odnoszące się do geograficznego namystu nad czasem, [w:] W. Maik, K. Rembowska, A. Suliborski (red.), Terytorium, region, miejsce - czas i przestrzeń w geografii. Podstawowe koncepcje i idee w geografii, t. 4, Bydgoszcz, s. 41-56. 
Young C., Light D., 2013, Corpses, dead body politics and agency in human geography: following the corpse of dr Petru Groza, „Transactions of the Institute of British Geographers” 38(1), s. 135-148.

ZABORSKi B., WRZOSEK A., 1939, Antropogeografia, [w:] Wielka geografia powszechna, Wydawnictwo Trzaski, Everta i Michalskiego, Warszawa.

ZDEBSKI J., 2006, Aktywność turystyczna w przebiegu życia, [w:] G. Golembski (red.), Turystyka w ujęciu podmiotowym i przestrzennym. Człowiek - przestrzeń - przedsiębiorstwo, Wydawnictwo Akademii Ekonomicznej w Poznaniu, Poznań, s. 41-48.

ZELINSKY W., 1994, Gathering Places for America's Dead: How Many, Where, and Why?, "The Professional Geographer" 46(1), s. 29-38.

ZIĘBINSSKA-WITEK A., 2005, Holocaust: problemy przedstawiania, Wydawnictwo UMCS, ss. 153.

ZIĘBIŃSKA-WiTEK A., 2012, Turystyka śmierci jako zjawisko kulturowe, „Teksty Drugie” 3, s. $174-186$. 


\section{Thanatourism. From 'Death Space' to Tourism Space (summary)}

The original study objects in thanatourism studies - a discipline originated in Poland by the author - were cemeteries (TANAS 2004, 2008b). The research has been continued in the form of numerous publications on the subject of death space used for tourism purposes. The general goal of these studies is to identify and describe travel to death space, which is referred to as thanatourism (TANAŚ 2006a), associated with dark tourism (LENNON, FOLEY 2000, STONE 2006) and cultural tourism. Using some examples, the author attempted to theoretically analyse the mechanisms generating the need to travel to death space (TANAŚ 2006b).

The study problem may be formulated as the following question: what is the meaning of death in the process of shaping tourist space? The answer lies in the identification and description of the process of enlarging tourist space by new spaces, originally regarded as non-tourist, in close correlation with the problems studied in tourism geography and cultural geography. The description and analysis regards the relation between death space and tourist space (functions, organization and use), the possibilities and ways of making use of death space in cultural tourism, as well as the geographical differentiation of the culture of death.

The object of study is the essence, i.e. the origins, evolution and change factors of death space, which is the travel destination. Death space includes material and nonmaterial elements gathered over time, which refer to commemorating death in geographical space, as well as to activities resulting in death, which are further referred to as the culture of death. Death space is seen by tourists as a separate part of geographical space, which undergoes functional changes under the influence of tourist traffic, becoming thanatourism space, which is the object of study.

For the purposes of this work, death has been defined as an ontological end of life, both subjective (of somebody) and objective (of something), identified through a system of symbols, as well as artifacts formed and collected in the process of the evolution and diffusion of cultures. Death is viewed first of all from the angle of cultural values (tangible and intangible), which represent the civilisational heritage, evaluated through the memory of it at the end of one's life.

The main assumptions of the thesis, which allow the author to put the study problem into a theoretical framework of socio-economic geography, are as follows: the geographical approach refers to a broadly understood humanistic conception of cultural geography, and takes into account the dialectic theory of socio-cultural reality, which offers the possibility to analyse the objective and subjective manifestations of social life 
(REMBOWSKA 2002b), as well as tourism geography; the study of the cultural aspects of social life is determined by the historical (temporal) changeability and geographical (spatial) differentiation; death space is diversified and dynamic; tourist space is a relational space (tourist - space), understood as individual (personal) tourist space, which is a total of spaces where tourist activity is pursued by an individual or a group of people. In certain situations tourist space will be also connected with a given territory - the tourist space of an area, with set borders (WŁODARCZYK 2009).

With a view to the study problem, study object and the assumptions, the author adopted the following hypothesis: in biological and cultural terms, death is a factor shaping geographical space, and especially the tourist space identified within it. Moreover, the author adopts three supporting theses: the way death space is organized results from the adopted cultural norms and draws human attention; death space has religious, educational, socializing and emotional assets; the development of pop-culture led to the growth of post-modernist interest in death space, as a result of which tourist products developed, making use of the elements of this space; the geographical differentiation of death space and its interpretation is the determining factor of thanatourism.

The book presents three basic issues: death, geography and tourism, while man and space are the conceptual foundation of the studies. The book consists of six chapters. In the first one, the author explains the conception, aims and assumptions of the work, as well as presents a short discussion on terminology and an analysis of selected literature. The second and third chapters present the cultural and geographical aspects of death. In chapter four, the author presents the role of man in shaping thanatourism space. The fifth chapter is devoted to the essence of thanatourism. Chapter six contains conclusions to the discussion about using death space in tourism.

The author defines death space as a fragment of geographical space, containing a set of objects which are carriers of meanings identifying the end of life, both subjective (of a person, animal or plant) and objective (of things, spaces), defined by a system of symbols. The interpretation of death space depends on cultural, social, economic, geographical (spatial) factors, as well as time. Death space is a general term, but it is saturated with meanings depending on the human environment around it. It is only the meaningful elements (e.g. graves, cemeteries, monuments, museums) that give particular character to death space.

On the basis of the presented theoretical studies of travelling to death space, the author defines thanatourism again, as a particular type of cultural tourism, involving trips to death space for cognitive, educational purposes, as well as pilgrimage and entertainment activity, where the object of the tourist's interest is the culture of death.

In the context of tourist traffic, thanatourism depends on the character of both, the tourism generating and the reception area, primarily as regards their socio-cultural (social behaviours, world view), historical (heritage and its interpretation), psychological (motives, needs and purposes), economic (tourist product) and geographical (spatial diversity and landscape) aspects.

Thanatourism should be regarded as cognitive and educational tourism, a part of cultural tourism, where the destinations are dark places (dark tourism) with products of the culture of death. At the same time, thanatourism is related to religious and entertainment tourism. 
Thanatourism may lead to socio-cultural transformations of the reception community as regards the following: the functioning of social institutions (protection of cemeteries, conservation activity, preservation of burial rituals and traditions, tourist development of death space by establishing walking trails or installing information boards); social attitudes and behaviours (approach to death, death pedagogy, care for burial sites and commemoration, cultural heterogeneity, tolerance, favour, isolation); the culture of local community (preserving identity, developing regional culture, secularization of the sacrum).

Thanatourism is a social phenomenon resulting from human interest in death space and death itself. It is a kind of activity which consists in the ability to read the symbolism of death space, together with the whole set of codes which are used to "write" this space. Such interests obviously come from the changes in the perception of death which have been taking place in the history of mankind, and have accumulated in images, gestures and memory. At present, they are objects of cognitive interest, especially in the material dimension of the sepulchral art and the spiritual dimension of remembrance and rituals.

Thanatourism leads to an interpretation of death, i.e. to an explanation of the object of cognition. Interpretation is an educational activity, whose aim is to explain meanings and relations by using direct experience and original objects. The power of interpretation lies in the ability to understand a phenomenon or object in depth. Death space makes people interpret it, and this interpretation as an educational process will depend on the value of the message which is the foundation of cognition. The main goal of interpreting death space or death itself should be to understand its sense and the changes in its perception, to develop sensitivity towards it, especially towards the death of a "fellow man", and to help in understanding the history and semiotics of death.

Educational classes organized in given death spaces reinforce the historical, religious or social message, as well as are an opportunity to present a particular world view. Learning history at sites which commemorate death is certainly a tourist activity, because becoming familiar with cultural heritage occurs through a direct contact with symbolic space. In this way, it is possible to enhance the process of building national identity and patriotic attitudes. The aim of visiting death space, from the pedagogical and educational perspective, is to raise awareness by means of transferring behavioral patterns. This may generate a conscious need to organize tourist infrastructure which propagates the knowledge of history, as well as bring the understanding of the activity of institutions working for the protection and preservation of cultural heritage and memory of tragic events.

The study that has been conducted points to the considerable potential of the culture of death and the possibility to use it as a part of thanatourism. It shows the growing popularity of travelling to death space, motivated by education, remembrance and religion on the one hand, and the need for entertainment on the other. The popular interpretation of death raises moral objections and criticism in the media. In the author's opinion, however, these are not fully justified. The publications quoted in the book confirm that contact with the culture of death, also in the pop-cultural dimension, may bring positive social effects, on the condition that people are properly prepared to interpret the commercialized product. Trips motivated by the desire for a direct and 
conscious encounter with suffering and death may certainly cause concern, because they use "another person's death" for an unusual purpose, which may be seen as pathology.

Social and cultural changes lead to some alterations in tourist preferences, including the tourists becoming interested in the type of space which was originally non-tourist but is turning into an individual tourist space or developed tourist space containing tourist infrastructure, as a reaction to tourist exploration and penetration. It may be concluded that the relations between death space and tourist space may become fairly stable, having an economic effect in the form of tourist products.

The author describes necrogeography and death geography. Research in these fields should lead to a more effective analysis of the spatial differentiation of the culture of death. The analysis of cemetery space, the distribution of cemeteries, their topography, inventory of graves, and the conservation and protection of sepulchral architecture creates vast opportunities to build the knowledge of identity, heritage and culture. Due to the use of GIS tools in the study of the morphology of cemeteries and their spatial distribution, fast and precise spatial-historical interpretation is possible of sites which prove and document origins and genealogy. Combined with other sciences, death geography, which deals with the study of the spatial aspect of the culture of death, may be helpful in the understanding of social and cultural differences, determined also by geographical factors through diffusion and cultural syncretism. In the times of a global moral crisis and wars of religious, cultural, political and geographical background, death geography also explains the spatial character of hazards generated by people and affecting their lives, including the tourist aspect.

In conclusion, the author believes that death understood as the termination of human life, as well as some biotic and abiotic elements of the Earth, landscape, space and objects, has a strong influence on the shape of geographical space, especially its part which is organized by people, i.e. the cultural space including tourist space. The way of organizing death space depends on the accepted cultural norms. Its constituents have religious, educational, socializing, emotional and entertaining value, thus modifying the extent and character of human interest in it. The postmodernist way of perceiving cultural heritage greatly increased people's interest in the pop-cultural (artistic, entertaining and sensational) aspects of death space. The main factor which determines thanatourism is then the geographical differentiation of death space and the geographical differentiation of its interpretation, which comes from the cultural differences among thanatourism creators, organizers and consumers. 